PNNL-13030

\title{
Technical Exchange on Improved Design and Performance of High Level Waste Melters - Final Report
}

Tanks Focus Area

RL3-7-WT-31 (Task 3)

S. K. Sundaram and M. L. Elliott

Pacific Northwest National Laboratory ${ }^{a}$, Richland, WA 99352

Dennis Bickford

Savannah River Technology Center, Aiken, SC 29808

September 1999

Prepared for the U. S. Department of Energy under contract DE-AC06-76RLO 1830

${ }^{a}$ Operated for the U.S. Department of Energy by Battelle under Contract DE-AC06-76RLO 1830 


\section{DISCLAIMER}

This report was prepared as an account of work sponsored by an agency of the United States Government. Neither the United States Government nor any agency thereof, nor any of their employees, make any warranty, express or implied, or assumes any legal liability or responsibility for the accuracy, completeness, or usefulness of any information, apparatus, product, or process disclosed, or represents that its use would not infringe privately owned rights. Reference herein to any specific commercial product, process, or service by trade name, trademark, manufacturer, or otherwise does not necessarily constitute or imply its endorsement, recommendation, or favoring by the United States Government or any agency thereof. The views and opinions of authors expressed herein do not necessarily state or reflect those of the United States Government or any agency thereof. 


\section{DISCLAIMER}

Portions of this document may be illegible in electronic image products. Images are produced from the best available original document. 


\section{Summary}

Researchers from three countries and a number of Department of Energy sites and national laboratories met in May 1999 to share ideas on the design and performance of high-level waste melter (HLW) technologies. A three-day workshop permitted an exchange of experience and ideas among the attendees. More than two dozen experts in the melter field discussed design and performance ideas that covered a variety of topics. Among the participants were personnel from Pacific Northwest National Laboratory (PNNL), Westinghouse Savannah River Company (SRTC), Idaho National Engineering and Environmental Laboratory (INEEL), and a number of corporate representatives from France and Russia.

The two major objectives of the workshop were far-reaching: 1) to provide a neutral forum on improved design and performance of HLW melters, and 2) to facilitate the full exposure of Idaho National Engineering and Environmental Laboratory (INEEL) to the whole spectrum of melter technology. Each presentation was followed by intensive discussion and exchanges with and among the participants. Topics covered a wide range, for example, from the effect of vanadium on the sulfate solubility in glasses to a discussion of low versus high-temperature vitrification process. A large portion of the first day was spent comparing different capabilities and processes. The second day of the technical exchange was devoted to INEEL and the status of their processes. Much of the third day was centered on the Defense Waste Processing Facility (DWPF).

This report is organized as follows. The technical exchange section follows the course of the workshop day-by-day and includes a list of important outcomes from the program of each day. Appendix $A$ is a copy of the technical program by hour and identifies the presenters. Appendix B lists the participants by employer and provides an address for each one. Appendix $C$ presents the questionnaire responses from selected participants. Appendix $\mathrm{D}$ consists of meeting handouts of the presentations. 


\section{Acronyms and Abbreviations}

$\begin{array}{ll}\text { BNFL } & \text { British Nuclear Fuels Limited } \\ \text { CCM } & \text { Cold Crucible Melter } \\ \text { CEM } & \text { Continuous Emission Monitors } \\ \text { CEA (France) } & \text { Commissariat a l'Energie Atomique } \\ \text { COGEMA } & \text { COmpagnie GEnerale des MAtieres Nucleaires } \\ \text { DWPF } & \text { Defense Waste Processing Facility } \\ \text { HAW } & \text { High-Activity Waste } \\ \text { HLW } & \text { High Level Waste } \\ \text { IDMS } & \text { Integrated DWPF Melter System } \\ \text { INEEL } & \text { Idaho National Engineering and Environmental Laboratory } \\ \text { MACT } & \text { Maximum Achievable Control Technology } \\ \text { PNNL } & \text { Pacific Northwest National Laboratory } \\ \text { SBW } & \text { Sodium Bearing Waste } \\ \text { SGN (France) } & \text { Societe Generale des Techniques Nouvelles } \\ \text { SRTC } & \text { Savannah River Technology Center } \\ \text { TFA } & \text { Tanks Focus Area } \\ \text { TIM } & \text { Technology Integration Manager } \\ \text { TTP } & \text { Technical Task Plan }\end{array}$




\section{Acknowledgments}

The authors would like to thank Bill Holtzscheiter, Technology Integration Manager (TIM) of Tanks Focus Area (TFA) for management and guidance and all participants of the technical exchange for their active and productive interaction. We would like to also thank Jim Rindfleisch, Bruce Staples, and Chris Musick of INEEL for their participation and for representing the INEEL team. This study was funded by the Department of Energy Office of Science and Technology through the Tanks Focus Area. Pacific Northwest National Laboratory is operated for the U.S. Department of Energy by Battelle under Contract DE-AC06-76RLO 1830. 


\section{Contents}

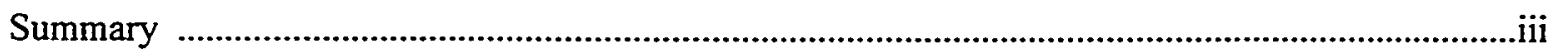

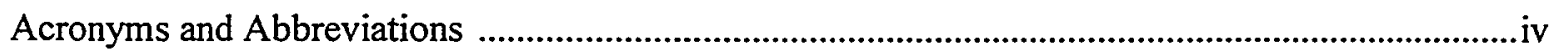

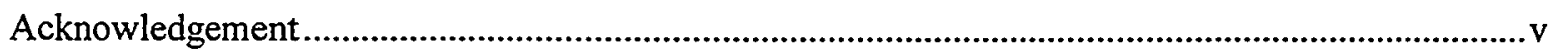

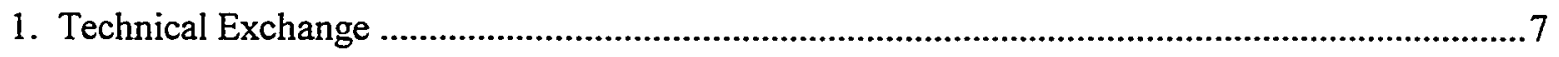

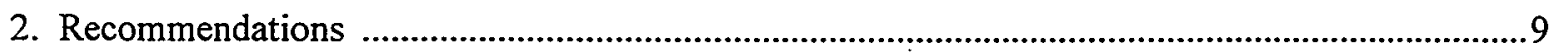

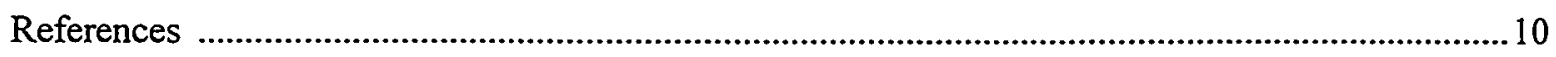

Appendix A - Technical Program

Appendix B - List of Participants

Appendix C - Questionnaire Responses

Appendix D - Meeting Handouts 


\section{Technical Exchange}

A technical exchange meeting on Improved Performance of High-Level Waste (HLW) Melters was held at the Sheraton Augusta, Augusta, Georgia, May 4-6, 1999, as a part of Technical Task Plan (TTP) RL3-7-WT-31, Task 3 (TTP 1999-2000). The Tanks Focus Area (TFA) meeting was organized by S. K. Sundaram and M. L. Elliott from Pacific Northwest National Laboratory (PNNL) and D. F. Bickford from Savannah River Technology Center (SRTC). Moderator Sundaram indicated the objectives of the meeting were:

1. To provide a neutral forum on improved design and performance of HLW melters

2. To facilitate the full exposure of Idaho National Engineering and Environmental Laboratory (INEEL) to the whole spectrum of melter technology.

With waste vitrification well underway at the Savannah River and West Valley sites, this meeting was timely. It was designed to discuss the state-of-the-art of melter technologies, identify problem areas and promising solutions, and to determine the scope for improvements in the technologies.

May 4, 1999:

The first day (5/4/99) of the meeting began with a program introduction by Bill Holtzscheiter (SRTC). Dennis Bickford (SRTC) briefly discussed the pour spout issue and noble metals concern in the Defense Waste Processing Facility (DWPF). The DWPF melter is in its fifth year of service (more than double the design limit of two years) and is expected to have two more years of service. This discussion was followed by an outline of Idaho site-related issues, presented by Chris Musick (INEEL).

Brad Bowan (GTS Duratek, a member of the British Nuclear Fuels Ltd. (BNFL) team) presented an overview of the historical development, melter capabilities, and melter testing results of GTS Duratek. He discussed a variety of topics including the bubbling technique to increase production, some downtime causes, technetium $(\mathrm{Tc})$ and silver $(\mathrm{Ag})$ retention, and $\mathrm{NO}_{\mathrm{x}}$ reduction. Sergey Stefanovsky (SIA Radon, Moscow, Russia) reviewed the history and the present state of the art of Russian vitrification technology. He noted different types of glasses (borosilicate, aluminosilicate, iron phosphate and aluminophosphate) used by Russian researchers. He indicated that vanadium addition increased sulfate solubility in borosilicate glasses. He also observed that zirconolite/pyrochlore-rich ceramics were best suited for actinide incorporation. Stefanovsky also elaborated on the Russian version of the cold crucible technology and its performance.

Two presenters were from France. Antoine Jouan (CEA, France) introduced the French cold crucible melter (CCM) technology and presented an overview of French capabilities. Melhman (SGN, France) described the COGEMA experience. He highlighted improvements in materials and design, advanced CCM, and their three plants. The first day concluded with a note on material corrosion and melter performance by Ken Imrich (SRTC).

In summarizing the first day of the technical exchange, the following topics were important outcomes:

1. Effect of vanadium doping on the sulfate solubility in glasses

2. Actinide incorporation in ceramics

3. Possible adaptation of pour system of CCM to joule-heated melter

4. DWPF - life-extension and maintenance currently more relevant

5. Materials evaluation in service. 
May 5. 1999:

The second day of the technical exchange was devoted to the Idaho site. Jim Rindfleisch (INEEL) presented an overview of the INEEL HLW program. Chris Musick (INEEL) updated the sodium-bearing waste (SBW) and calcine compositions. Bruce Staples (INEEL) provided the status of glass formulation development. Bruce's presentation initiated discussions on solubility limits of phosphate, calcium fluoride, zirconium, sulfates, and potassium in borosilicate glass and other aspects of Idaho wastes. Chris Musick (INEEL) summarized the status of the process development at INEEL. He discussed the advantages and disadvantages of $1150^{\circ} \mathrm{C}$ (low temperature) vs. $1450^{\circ} \mathrm{C}$ (high temperature). He expressed concern about the corrosivity of melter and off-gas materials of construction due to fluorides, chlorides, sulfates, and nitrates. Musick also generated discussion on the choice of denitration/evaporation of feed, prior to feeding the melter or the use of reductants (for example, sugar, urea) in the melter to increase melt rates. Russian and French participants shared the opinion that the CCM technology could handle the nitrates and hence denitration was not necessary. Melter tonnage, throughput, and lifetime were also discussed.

Sam Ashworth (COGEMA/LMITCO) summarized the status of emission monitoring at INEEL. Volatility of mercury, technetium, and cesium was a major concern. Thermodynamic data on formation of $\mathrm{CaF}_{2}-\mathrm{HF}$ and $\mathrm{Tc}-\mathrm{HTcO}_{4}$ and the electrochemical reduction of mercury were also presented. Steam stripping of mercury in DWPF was noted. PNNL reports confirmed formation of elemental mercury. Andrea Chambers (INEEL) further elaborated on these issues and the reliability of continuous emission monitors (CEM). Jack Zamecnik (SRTC) presented the DWPF off-gas system and discussed its performance.

The following are the second day outcomes of the technical exchange:

1. Solubility limits of species in glasses

2. Low temperature vs. high temperature vitrification

3. Pre-melter options

4. Enhancement of melt rate

5. Corrosion of materials of construction

6. Volatility of mercury, technetium, and cesium.

May 6. 1999:

On the third day, the presentations centered on DWPF. Rich Edwards (DWPF) presented an overview of DWPF operations and productivity. He elaborated on the pour spout problem and inserts. He noted that an insert typically lasted through 34 to 97 pours. Dennis Bickford (SRTC) described the stir-melter technology and engineering-scale pour spout tests at Clemson University. Mike Smith (SRTC) summarized the noble metals studies using the Integrated DWPF Melter System (IDMS). Ruthenium $\mathrm{Ru}$ ) was the most retained element in the melter and the $\mathrm{Ru}$ settled during idling. Supportive of an earlier PNNL report (Cooper et. al. 1993), a non-linear concentration relationship between Ru concentration in glass and the melter idling time was observed.

Bond Calloway (SRTC) pointed out that off-gas surges could be expected from slurry fed melters. When comparing surge activity from the DWPF melter to that from the SRTC 1/2-scale melters and from smaller ones, it was discovered that the magnitude of the surges increased as melters got larger. Surges could lead to uncontrolled release of radioactive off-gas or glass, depending on the design of the off-gas system. 
However, surges could be controlled within the bounds of off-gas system design parameters through feed chemistry and melter operating conditions.

Ken Imrich (SRTC) summarized the visual and metallurgical observations of corrosion of different components (thermowells, primary and backup film cooler brush, level probe, borescopes, feed tubes, pour spout, lid heaters, backup off-gas line, isolation valves, primary quencher, vent line, and primary offgas line) of IDMS after 7 years of operation and those of DWPF after 10 months of operation. He emphasized the need to look for newer or better materials/alloys. A modified Inconel 690 will be looked at for improved corrosion resistance. Alloy development work already has been initiated at SRTC. Sundaram (PNNL) briefly discussed electrochemical testing of alloys for corrosion in melts.

Summarizing the third day of the technical exchange, the following major areas were identified:

1. Pour spout and inserts

2. Noble metals

3. Off-gas surges in melters

4. Materials performance and improved alloys.

With final remarks from Sundaram (PNNL) and Bill Holtzscheiter (SRTC), the technical exchange concluded. The outcomes of the meeting helped the TFA participants in formulating future technical work.

\section{Recommendations}

The technical exchange facilitated good integration among different technology providers and users. The following are major recommendations made based on the outcomes of the technical exchange:

- Joule-heated melter technology still dominates the technology arena. The TFA should continue to focus at improvements of this technology for a wider user base.

- The high-frequency induction melting technology has developed substantially. Testing in French and Russian units is endorsed. If these tests are successful, the TFA should investigate the relative benefits of establishing a laboratory-sized test unit in the United States.

- Major DWPF issues are pour spout design and noble metals. Modeling should be used in optimizing the pour spout design. Development of a quantitative relationship between noble metal concentration and processing parameters is crucial in addressing this issue. The existing expertise at PNNL, SRTC, and FIU should be integrated well in solving these problems.

- The DWPF melter having outlived its expected design life, it will be strategic to maintain and improve its capabilities. Incremental, realistic, and cost-saving improvements in addressing the above issues will be preferred over drastic (and expensive) design changes.

- A wide range of technological choices has been presented to INEEL for Idaho site needs. The TFA will be instrumental in matching Idaho needs with the existing and potential expertise across other organizations.

- Materials corrosion is a persistent technological issue in joule-heated systems. With the new range of waste chemistries at Idaho on the horizon, the corrosion problem cannot be ignored. Corrosion of materials presently known or newer materials in contact with various simulated Idaho glasses should be evaluated in identifying suitable materials of construction. 


\section{References}

Technical Task Plan (TTP) RL3-7-WT-31, Task 3, 1999; Technical Task Plan (TTP) RL3-7-WT-31, Task A, 2000.

M. F. Cooper, M. L. Elliott, L. L. Flyer, C. J. Freeman, J. J. Higginson, L. A. Mahoney, and M. R. Powell. 1993. Research-Scale Melter Test Report," PHTD-K902, Pacific Northwest National Laboratory, Richland, Washington. 


\section{Appendix A}

\section{Technical Program}




\section{Technical Exchange}

on

Improved Design and Performance of High Level Waste Melters

Organizers: $\quad$ S. K. Sundaram and M. L. Elliott, PNNL

D. F. Bickford, SRTC

\section{TECHNICAL PROGRAM}

Sheraton Augusta, Augusta, GA

May 4-6, 1999

A-2 


$\begin{array}{ll}\text { Tuesday, May 4, } 1999 \\ \text { 08:00 AM } & \text { Welcome - S. K. Sundaram (PNNL) } \\ \text { 08:05 } & \text { Remarks by TIM - Bill Holtzscheiter (SRTC) } \\ \text { 08:10 } & \text { Dennis Bickford (SRTC) - SRS Concerns } \\ \text { 08:20 } & \text { Chris Musick (INEEL) - Idaho Needs } \\ \text { 08:30 } & \text { Bradley W. Bowan II (GTS Duratek) } \\ \text { 09:45 } & \text { Coffee Break } \\ \text { 10:00 } & \text { Sergy V. Stefanovsky (SIA Radon, Moscow, Russia) } \\ \text { 11:45 } & \text { Lunch } \\ \text { 12:45 PM } & \text { Antoine Jouan (CEA, France) } \\ \text { 01:45 } & \text { G. Melhman (SGN), R.D. Quang (COGEMA) and Sam Ashworth (LMITCO) } \\ 02: 45 & \text { Corrosion Issues - Ken Imrich (SRTC) } \\ 03: 45 & \text { Coffee Break } \\ 04: 00 & \text { Discussion and Summary } \\ 05: 00 & \text { End of the Day }\end{array}$




\section{Wednesday, May 5, 1999}

08:00 AM INEEL HLW Program Review - Jim Rindfleisch (INEEL)

08:30 High Level Waste Compositions/Baseline Flowsheet - Chris Musick and Rod Kimmit (INEEL)

- SBW and Calcine Compositions

- SBW-HAW and Calcine-HAW Compositions

Current Status of the Feasibility Studies - Rod Kimmit

09:00 Waste Form Development - Bruce Staples (INEEL)

- Current status of glass formulation development

- Feedback from colleagues on the following technical subjects:

- Solubility limits of phosphate, calcium fluoride, zirconium, sulfates, and potassium in borosilicate glass

- Effects of durability and processing from niobium

- Effects that temperature will have on solubility and durability

10:15 Coffee Break

10:30 Process Development Selection Criteria - Chris Musick and Rod Kimmit (INEEL)

- Current status of INEEL process development program

- Feedback from colleagues on following technical issues:

- Advantages/disadvantages of $1150^{\circ} \mathrm{C}$ Vs $1450^{\circ} \mathrm{C}$ melter systems

- Corrosivity of melter and off-gas materials of construction with respect to fluorides, chlorides, sulfates, and nitrates

- HAW fraction - advantages/disadvantages of denitration/evaporation of feed prior to being fed to the melter

- Utilization of a catalyst (sugar, urea, etc.) for denitration in the melt chamber to increase melt rates

- Qualification of melter system

12:00 Noon Lunch Break

01.00 PM Off-Gas Monitoring and Control - Sam Ashworth and Andrea Chambers (INEEL) and Jack Zamegnik (SRTC)

- Current status of continuous emissions monitoring being conducted at INEEL

- Technical issues to be discussed with workshop colleagues

- Control and treatment of volatility of mercury, technetium, and cesium

- MACT compliance

- Continuous emissions monitoring

- $\mathrm{NO}_{\mathrm{x}}$ abatement/control

02:45 Coffee Break

03:00 Off-Gas Monitoring and Control (continued)

04:00 Discussion and Summary

05:00 End of the Day 


$\begin{array}{ll}\text { Thursday, May 6, } 1999 \\ \text { 08:00 AM } & \text { Overview of DWPF Operations and Productivity - Rich Edwards (SRTC) } \\ \text { 09:00 } & \text { Pour Spout - Dennis Bickford (SRTC) } \\ \text { 10:15 } & \text { Coffee Break } \\ \text { 10:30 } & \text { Noble Metals - Mike Smith (SRTC) } \\ \text { 12:00 Noon } & \text { Lunch } \\ \text { 01:00 PM } & \text { Off-gas Design and Performance - Jack Zamegnik/Bond Calloway (SRTC) } \\ \text { 02:00 } & \text { Materials Performance - Ken Imrich (SRTC) and S. K. Sundaram (PNNL) } \\ \text { 03:30 } & \text { Coffee Break } \\ 04: 00 & \text { Discussion and Summary } \\ 05: 00 & \text { End of the Day }\end{array}$




\section{Appendix B}

\section{List of Participants}

(Alphabetical by last name with first name in parenthesis). 


\section{ENVITCO, Inc}

David M. Bennert (David)

ENVITCO Inc.

3400 Executive Parkway, P. O. Box 2451

Toledo, OH 43606-0451

Phone: (419) 539-7297; (808)-628-3680

Fax: (419) 537-1369

E-mail: dbennert@mindspring.com

\section{FLORIDA INTERNATIONAL UNIVERSITY}

Rajiv Srivastava (Rajiv)

Project Manager

Hemispheric Center for Environmental Technology

Florida International University

10555 West Flagler St., CEAS 2100

Miami, FL 33174

Phone: (305) 348-6621

Fax: (305) 348-1697

E-mail: rajiv@eng.fiu.edu

\section{FRANCE-USA PARTNERS}

Sam Ashworth (Sam)

COGEMA Engineering Corporation

P. O. Box 840

Richland, WA 99352-0840

Phone: (509) 372-8256

Fax: (509) 372-8077

E-mail: sashworth@cogema-engineering.com

Antoine Jouan (Antoine)

Deputy Manager

Centre d'Etudes Nucléaires de la Vallée du Rhône

Marcoule

B.P. 171-F-30207 BAGNOLS-SUR-CĖZE Cédex,

France

Phone: 01133466796376

Fax: 01133466796030

E-mail: antoine.jouan@,cea.fr

G. Melhman (Melhman)

SGN

1 , rue des Herons'Montigny-le-Bretonneux

78182 St. Quentin-en-Yveleines CEDEX

France

Phone: 01133139485000

Fax: $\quad 01133139486061$

E-mail: N/A 
R. D. Quang (Quang)

COGEMA

1, rue des Herons'Montigny-le-Bretonneux

78182 St. Quentin-en-Yveleines CEDEX

France

Phone: 01133139485246

Fax: $\quad 01133139485167$

E-mail: dsdp@dial.oleane.com

Vijay K. Sazawal (Vijay)

COGEMA, Inc.

7401 Wisconsin Avenue

Bethesda, MD 20814

Phone: (301) 986-8585

Fax: (301) 652-8479

E-mail: vsazawal@.cogema-inc.com

\section{GTS Duratek/BNFL}

Bradley W. Bowan II (Brad)

GTS Duratek

10100 Old Columbia Road

Columbia, MD 21046

Phone: (410) 312-5100, Ext. 119

Fax: (410) 290-9070

E-mail: BBOWAN@gtsduratek.com

Will Eaton (Will)

GTS Duratek

3000 George Washington Way

Richland WA, 99352

Phone: (509) 371-3168

Fax: (509) 371-3004

E-mail: weaton@,bnflinc.com

\section{INEEL}

A. Chambers (Andrea)

Lockheed Martin Idaho Technologies Company

P. O. Box 1625, MSIN 3625

Idaho Falls, ID 83415

Phone: (208) 526-9008

Fax: (208) 526-4017

Email: agc5@ineel.gov

C. A. Musick (Chris)

Lockheed Martin Idaho Technologies Company

P. O. Box 1625, MSIN 5218

Idaho Falls, ID 83415 
Phone: (208) 526-7283

Fax: (208) 526-3499

Email: cam3@ineel.gov

J. A. Rindfleisch (Jim)

Lockheed Martin Idaho Technologies Company

P. O. Box 1625, MSIN 5218

Idaho Falls, ID 83415

Phone: (208) 526-3114

Fax: (208) 526-5937

Email: jimr@ineel.gov

B. A. Staples (Bruce)

Lockheed Martin Idaho Technologies Company

P. O. Box 1625, MSIN 5218

Idaho Falls, ID 83415

Phone: (208) 526-3449

Fax: (208) 526-5937

Email: bsta@ineel.gov

PNNL

M. L. Elliott (Mike)

Pacific Northwest National Laboratory

P. O. Box 999, MSIN K6-24

Richland, WA 99352

Phone: (509) 376-9858

Fax: (509) 376-31080

E-mail: michael.elliott@pnl.gov

J. M. Perez, Jr. (Joe)

Pacific Northwest National Laboratory

P. O. Box 999, MSIN A0-21

Richland, WA 99352

Phone: (509) 376-5982

Fax: (509) 373-0733

E-mail: joe.perez@pnl.gov

S. K. Sundaram (Sundaram)

Pacific Northwest National Laboratory

P. O. Box 999, MSIN K6-24

Richland, WA 99352

Phone: (509) 373-6665

Fax: (509) 376-3108

E-mail: sk.sundaram@pnl.gov

\section{RUSSIA}

Sergey V. Stefanovsky (Serge)

SIA RADON 
7 Rostovskiy $2 / 14$

Moscow, Russia 119121

Phone: 7 (095) 919-3194

Fax: $\quad 7$ (095) 916-4771, 7 (095) 919-3194

E-mail: itbstef@cityline.ru

SAVANNAH RIVER TECHNOLOGY CENTER

D. F. Bickford (Denny)

Westinghouse Savannah River Company

Building 773-43A, Room 113

Aiken, SC 29808

Phone: (803) 725-3737

Fax: (803) 725-4704

E-mail: dennis.bickford@srs.gov

T. B. Calloway (Bond)

Westinghouse Savannah River Company

Building 704-1T, Room 205

Aiken, SC 29808

Phone: (803) 557-7757

Fax: (803) 557-7210

E-mail: bond.calloway@srs.gov

R. J. O'driscoll (Richard)

Westinghouse Savannah River Company

Building 704-30S, Room 5

Aiken, SC 29808

Phone: (803) 208-6534

Fax: Not available

E-mail: richard.odriscoll@srs.gov

R. F. Edwards (Rich)

Westinghouse Savannah River Company

Building 704-25S, Room 2

Aiken, SC 29808

Phone: (803) 208-7143

Fax: (803) 208-6158

E-mail: richard.edwards@srs.gov

J. T. Gee (Jim)

Westinghouse Savannah River Company

Building 704-25S, Room 4

Aiken, SC 29808

Phone: (803) 208-6463

Fax: (803) 208-6158

E-mail: james.gee@srs.gov

J. A. Gentilucci (Joe)

JAG Tech Services, Inc. 
127 Savannah Dr.

Aiken SC 29803-5833

Phone: (803) 648-7180

Fax: (803) 641-2004

E-mail: jagtech@groupz.net

Alternate contacts

Westinghouse Savannah River Company

Building 704-28S

Aiken, SC 29808

Phone: (803) 208-7168

E-mail: j.gentilucci@srs.gov

C. R. Goetzman (Rudy)

Westinghouse Savannah River Company

Building 773-A, Room A-262

Aiken, SC 29808

Phone: (803) 725-3978

Fax: (803) 725-4704

E-mail: rudy.goetzman@srs.gov

E. K. Hansen (Eric)

Westinghouse Savannah River Company

Building 704-T, Room 122

Aiken, SC 29808

Phone: (803) 557-7683

Fax: (803) 557-7210

E-mail: erich.hansen@srs.gov

E. W. Holtzscheiter (Bill)

Westinghouse Savannah River Company

Building 773-A, Room A-232

Aiken, SC 29808

Phone: (803) 725-2170

Fax: (803) 725-4704

E-mail: bill.holtzscheiter@srs.gov

K. J. Imrich (Ken)

Westinghouse Savannah River Company

Building 773-A, Room D-1145

Aiken, SC 29808

Phone: (803) 725-9549

Fax: (803) 725-7369

E-mail: ken.imrich@srs.gov

D. C. Iverson (Dan)

Westinghouse Savannah River Company

Building 704-30S, Room 9

Aiken, SC 29808

Phone: (803) 208-7187 
Fax: (803) 208-6158

E-mail: dan.iverson@srs.gov

W. D. Kerley (Bill)

Westinghouse Savannah River Company

Building 704-S, Room 17

Aiken, SC 29808

Phone: (803) 208-6052

Fax: (803) 725-6158

E-mail: bill.kerley@srs.gov

S. L. Marra (Sharon)

Westinghouse Savannah River Company

Building 704-T, Room 104

Aiken, SC 29808

Phone: (803) 557-7639

Fax: (803) 557-7210

E-mail: sharon.marra@srs.gov

David K. Peeler (David)

Westinghouse Savannah River Company

Building 773-43A, Room 111

Aiken, SC 29808

Phone: (803) 725-0623

Fax: (803) 725-4704

E-mail: david.peeler@srs.gov

C. T. Randall (Chris)

Westinghouse Savannah River Company

Building 773-42A, Room 132

Aiken, SC 29808

Phone: (803) 725-1077

Fax: (803) 725-4704

E-mail: chris.randall@.srs.gov

F. G. Smith (Frank)

Westinghouse Savannah River Company

Building 773-42A, Room 178

Aiken, SC 29808

Phone: (803) 725-9780

Fax: (803) 725-8829

E-mail: frank02.smith@.srs.gov

M. E. Smith (Mike)

Westinghouse Savannah River Company

Building 773-43A, Room 116

Aiken, SC 29808

Phone: (803) 725-5863

Fax: (803) 725-4704

E-mail: michael02.smith@srs.gov 
J. R. Zamecnik (Jack)

Westinghouse Savannah River Company

Building 773-41 A, Room 117

Aiken, SC 29808

Phone: (803) 725-4535

Fax: (803) 725-2978

E-mail: jack.zamecnik@srs.gov 


\section{Appendix C}

Questionnaire Responses 


\section{RUSSIAN RESPONSE}

(STEFANOVSKY) 


\section{INTRODUCTION}

SIA Radon is responsible for management of low- and intermediate-level radioactive waste (LILW) produced in Central Russia. In cooperation with Minatom organizations Radon carries out R\&D programs on treatment of simulated high level waste (HLW) as well. Radon scientists deal with a study of materials for LILW, HLW, and Nuclear Power Plants (NPP) wastes immobilization, and development and testing of processes and technologies for waste treatment and disposal.

Radon is mostly experienced in LILW vitrification. This experience can be carried over to HLW vitrification especially in field of melting systems. The melter chosen as a basic unit for the vitrification plant is a cold crucible. Later on Radon experience in LILW vitrification as well as our results on simulated HLW vitrification are briefly described.

\section{A1. System Performance - Glass.}

\section{Product Quality.}

The current glass for the Radon LILW vitrification plant is a borosilicate composition containing (in wt.\%) waste oxides (30-35), $\mathrm{CaO}(10-15), \mathrm{B}_{2} \mathrm{O}_{3}(5-8), \mathrm{Al}_{2} \mathrm{O}_{3}$ (3-7), $\mathrm{SiO}_{2}$ (45-50). The process temperature is $1150{ }^{\circ} \mathrm{C}$. NPP (WWER) waste oxide content in glass may reach 40$45 \mathrm{wt} . \%$.

a. Glass durability approximately corresponds to durability of reference glass.

b. Phase separation occurs when waste contains sulfates, chlorides, molybdates or chromates. Maximum content is $\sim 0.8-1.5$ wt.\% each of $\mathrm{SO}_{3}, \mathrm{MoO}_{3}, \mathrm{CrO}_{3}, \mathrm{Cl}$. Glasses for special purposes; when $\mathrm{SO}_{3}$ and $\mathrm{Cl}$-content exceeds 2 wt.\%, have been also designed. These are aluminophosphate and vanadia-doped glasses, which can incorporate up to 5-7 wt.\% and 3-5 wt.\% $\mathrm{SO}_{3}$ respectively. Usually phase separation in the cold crucible must be prevented to avoid contact the metallic crucible walls with low viscous high corrosive sulfate/chloride melt. Occurrence of the "yellow phase" on the glass surface in containers is prohibitive due to low chemical durability of this phase.

c. Glass is durable to devitrification. Devitrification may take place after thermal treatment of LILW glass for hundreds of hours at $400-450{ }^{\circ} \mathrm{C}$ (particular values are variable due to variability of the LILW and glass compositions). Some crystalline phases in quite homogeneous glass may occur. These are apatite-type phases, spinels, tridymite grains. Their total content in melt is very low. Any effects on melter operation or glass durability have not been observed.

d. The Radon waste vitrification plant provides for slurry feeding (undissolved feed). Special waste preparation is required. Liquid waste is concentrated to 1000-1000 $\mathrm{kg} / \mathrm{m}^{3}$, mixed with glass forming additives (datolite, sandstone) and bentonite to obtain homogeneous slurry with water content $20-25 \mathrm{wt} . \%$. Estimated glass residence time in the melter is $2.5-3$ hours. 


\section{Processing rate.}

Maximum specified glass processing rate is $25 \mathrm{~kg} / \mathrm{h}$. Average glass processing rate at slurry feeding ( $25 \mathrm{wt} . \%$ water content) is 17 to $21 \mathrm{~kg} / \mathrm{h}$. The melter with glass productivity up to $50 \mathrm{~kg} / \mathrm{h}$ has been designed and constructed. The melter with melt productivity up to 200-500 $\mathrm{kg} / \mathrm{h}$ is under design now.

a. Total amount of glass produced up to date is about 2.5 metric tons. Total operation time is about 230 hours. Maximum continuous operation time was 72 hours. A number of operation cycles was 16 . Maximum melter lifetime is not determined yet. Estimated lifetime is about 3000 hours.

\section{Range of waste handling capabilities.}

a. Restrictions are concerned sulfate and chloride ions only (see above). Maximum losses of such semi-volatile components as sodium, boron and cesium (ruthenium is not present in LILW) from the melter at process temperature $\left(1150{ }^{\circ} \mathrm{C}\right)$ are $0.5-1.5$, $\sim$, and 3-5\% respectively. Other problem chemical components are transition metal compounds, which are able to be reduced during melting at high temperatures following by formation of crystalline or metallic phases ( $\mathrm{Fe}, \mathrm{Ni}, \mathrm{Mo}, \mathrm{V}$, noble metals). Metallic phase can be accumulated at the bottom of the cold crucible or metallic drops can contact the tubes forming the cold crucible walls initiating breakdown and resulting in failure.

b. The cold crucible is able to process insoluble and conductive compounds. No restriction on insoluble species. Electric conductivity of the slurry doesn't effect on melter performance.

c. Slurries can be processed in the cold crucible. Both liquid and solid wastes can be handled. No restrictions have been established.

d. Fissile materials can be handled. Uranium accumulation in the cold crucible has never been observed.

e. The cold crucible is able to process metallic, inorganic, and organic wastes depending on operating frequency. At the frequency range used at Radon for treatment of liquid and solid inorganic wastes the restrictions are on resistivity $\left(0.025-0.055 \mathrm{Ohm}^{*} \mathrm{~m}\right)$ and viscosity (4-8 $\mathrm{Pa}^{*} \mathrm{~s}$ ) ranges. Within these ranges any inorganic materials may be melted.

f. In the cold crucible operated at the frequency range used at Radon metallic waste can not be handled. Some wastes require special treatment. Waste as large pieces must be crushed. Organic waste must be fed onto a surface of the melt formed in advance. Waste with high content of volatile components can not be handled in the cold crucible without sealing and operation over barometric pressure.

g. Acceptable processable glass property ranges are as follows:

Viscosity $\quad-4-8 \mathrm{~Pa}^{*} \mathrm{~s}$ at process temperature;

Viscosity vs. temperature - glass melt must be "long";

Resistivity $\quad-0.025-0.055 \mathrm{Ohm}^{*} \mathrm{~m}$;

Resistivity vs. temperature- resistivity must be stable within wide temperature range;

Precipitates - up to $20 \mathrm{wt} \%$ of precipitate in the melt is allowed. 


\section{A2. System Performance - Synroc.}

\section{Product quality.}

The most advanced method of HLW immobilization is incorporation in Synroc. Formation of the Synroc assemblage zirconolite+"hollandite"+perovskite+rutile by melt crystallization has been proven. Properties of the melted Synroc are very similar to hot-pressed Synroc, including chemical durability and radiation stability, and waste elements partitioning. We used conventional approach: Synroc-C with 20 wt.\% HLW calcine. The processing temperature is $1500-1600{ }^{\circ} \mathrm{C}$.

a. Chemical durability of the melted Synroc-C is approximately the same as the hotpressed Synroc-C.

b. No phase separation.

c. Product is fully crystalline.

d. The Synroc melting process is performed in the cold crucible by the same way as glass.

Both dry and slurry feeding are possible.

\section{Processing rate.}

Synroc melt processing rate depends on electric power and crucible design. Maximum melt productivity at existing bench-scale plant is up to $20 \mathrm{~kg} / \mathrm{h}$.

a. Total amount of Synroc produced up to date is about $200 \mathrm{~kg}$.

\section{Range of waste handling capabilities.}

a. No problems with incorporation of radionuclides of strontium, rare earth, and actinide elements in Synroc through melting. Problems occur with incorporation of cesium and ruthenium. Cs loss may reach $10-15 \%$ at temperatures $1500-1600{ }^{\circ} \mathrm{C}$. Cs and $\mathrm{Ru}$ losses are reduced if process is carried out under the calcine layer on the melt surface. Permanent control of the layer stability is required:

b. No problems with handling of insoluble and conductive components.

c. Both dry and slurry feeding are possible.

d. No problems. $\mathrm{U}$ and $\mathrm{Pu}$ are incorporated in zirconolite and pyrochlore.

e. To immobilize non-partitioned $\mathrm{HLW}$ and $\mathrm{Cs} / \mathrm{Sr}$ fraction of $\mathrm{HLW}$ the conventional Synroc-C can be used. To immobilize rare earth-actinide fraction zirconolite-, pyrochlore- or murataite-based ceramics can preferably be used. All of them may be melted in the cold crucible.

f. The same as for glass.

g. Acceptable processable Synroc melt property ranges are as follows:

Viscosity - 4-8 $\mathrm{Pa} \cdot \mathrm{s}$ at process temperature;

Viscosity vs. temperature - as melt is "short", overheating by $100-150{ }^{\circ} \mathrm{C}$ is required;

Resistivity $\quad-0.025-0.055 \mathrm{Ohm} \cdot \mathrm{m}$;

Precipitates - up to $20 \mathrm{wt} \%$ of precipitate in the melt is allowed. 


\section{B. Pouring}

1. For the cold crucible with glass (melt) productivity $25 \mathrm{~kg} / \mathrm{h}$ melt is poured once an hour. Pouring rate ranges between 3 and $12 \mathrm{~kg} / \mathrm{min}$.

2. Problems with clogging of drainage with frozen melt may occur. This is mechanically broken. Another problem is corrosion of pouring unit elements.

3. Application of high productive melters leads to the increase of the crucible dimensions and volume of on-time melt pouring portion. Drainage with greater diameter can be used. The increase of drainage (pouring tube) diameter improves pouring reliability. Pouring unit design, in particular application of additional heating of the pouring tube, may be improved if necessary.

\section{Noble metals.}

1. Noble metals are absent in LILW. We incorporated in Synroc simulated HLW, containing Ag only.

2. No any settling/electrode-shorting problems at Synroc melting. Ag particles were dispersed within the Synroc bulk

\section{Redox.}

1. Most of the LILW components are present in oxidized form (nitrates, sulfates, carbonates). LILW vitrification is carried out under oxidizing conditions in air. Melting of Synroc with simulated HLW must be performed under slightly reducing conditions to avoid formation of molybdates, chromates, etc., and to transform transition element to lower valence states. It is achieved by application of reducing agents.

2. Redox measurement and control during LILW vitrification process are not performed.

3. Foaming or metals reducing during vitrification or Synroc melting were not observed.

\section{E. Technical Maturity.}

1. Existing LILW vitrification plant is equipped with three melters - the cold crucibles each with glass productivity up to $25 \mathrm{~kg} / \mathrm{h}$. Total glass productivity reaches up to 75 $\mathrm{kg} / \mathrm{h}$. This plant is designed for vitrification of liquid waste with volume activity to $\sim 10 \mathrm{MBq}$ per litre.

2. Current maximum melter capacity (glass productivity) is up to $25 \mathrm{~kg} / \mathrm{h}$ for borosilicate feed with $20 \%$ water content. Melter and energy source (high frequency generator of $250 \mathrm{~kW}$ power) have been designed and manufactured. Estimated glass productivity is $35-50 \mathrm{~kg} / \mathrm{h}$ (slurry feeding). Dry feeding increases glass productivity by a factor of $\sim 1.5$. 


\section{F. Facility/System Integration.}

1. Insoluble components content in LILW is not limited. LILW handled at SIA Radon has $\mathrm{pH}=8-12$, which can be corrected if necessary. Reduction of $\mathrm{pH}<5-6$ results in volatilization.

2. Off-gas system parameters are as follows:

Off-gas rate $\quad-25-35 \mathrm{~m} 3 / \mathrm{h}$;

Major components $\quad-\mathrm{NO}_{\mathrm{x}}$, radioactive aerosols;

Particle size distribution (wt.\%) - <1.5 $\mu \mathrm{m}$ (14-26), 1.5-3.0 (17-42), 3.0-5.0 (4-13), $5.0-9.0(10-23),>9.0(9-19)$.

Off-gas system consists of filtration unit, absorption unit, and catalytic $\mathrm{NO}_{\mathrm{x}}$ decomposition unit. The first unit provides for gas purification from dust and aerosols using sleeve filter with pulse regeneration. The second unit purifies from fine aerosols using HEPA filter. Absorption unit (three packed absorbers) produces nitric acid. Finally, off-gas is purified from $\mathrm{NO}_{\mathrm{x}}$ in catalytic reactor with $\mathrm{NH}_{3}$.

3. A number of melting streams is three. Special requirements for placement are absent.

4. Plant service requirements are availability of steam, salt free water, compressed air, vacuum line, electric energy supply, $\mathrm{NH}_{3}$. The main parameters (glass productivity $75 \mathrm{~kg} / \mathrm{h}$ ) are water flow rate $-50 \mathrm{~m}^{3} / \mathrm{h}$, steam rate $-700 \mathrm{~kg} / \mathrm{h}$, power $-\mathrm{kW}, \mathrm{NH} 3$ flow rate - up to $5 \mathrm{~kg} / \mathrm{h}$., compressed air flow rate $-3 \mathrm{~m}^{3} / \mathrm{h}$.

5. Overall dimension of the cold crucible with glass productivity of $25 \mathrm{~kg} / \mathrm{h}$ used at existing LILW vitrification plant are $700 \mathrm{~mm}$ in height, $600 \mathrm{~mm}$ in length, $470 \mathrm{~mm}$ in width. Empty melter weight is $65 \mathrm{~kg}$. Weight of the melter filled with glass is 130 $\mathrm{kg}$. Special requirements for melter maintenance and replacement are absent. They will occur if the cold crucible will be applied to $\mathrm{HLW}$ vitrification. In this case remote operation and maintenance are required. The key advantage of the cold crucible over Joule heated ceramic melter is smaller overall dimensions and weight facilitating its dismantling, removal and disposal. One more restriction is electric cable length between HF generator and capacitors battery to whom inductor is joined.

6. The cold crucible is able to be remotely operated.

7. Currently, melt is poured into 18 litre containers. Ability to fill / handle 2' diameter $x$ $10^{\prime}$ tall canisters is also exist.

\section{G. Operability}

1. The melter is remotely operated and controlled from control panel. All the controllers are electrically-power-operated. All the monitored and controlled parameters are coupled with control panel and computer. Control system collects, represents, and handles information. Complete automation of the process is planned. Control algorithms, software and design project have been designed. Currently, remote monitoring of melt surface in the melter using self-designed thermomeasuring device based on computerized thermoviser is performed. Heat flows through the melter walls and "skull" thickness are also monitored. Automated control of the generator's parameters, inductor location, pouring unit electromechanical drive is performed. Batch is automatically fed in portions. Time to start feeding is controlled by 
temperature of surface of the batch fed in the cold crucible. Controlled parameters are cooling water flow rate and temperature, underpressure in the melter.

2. The plant is able to be adapted for operation in radioactive environment.

3. The melter - cold crucible has small overall dimensions and melt bulk is not great. Start up duration is about 1 hour. Cooling time to room temperature is about 3.5 hours. The melter is manufactured from metal pipes, water-cooled, and therefore, fire safe.

4. The melter - cold crucible consists of inductor, crucible, cover, pouring unit, start-up unit. Any element may be easily replaced in the case of failure.

5. Estimated lifetime of the cold crucible is 3000 hours.

\section{H. Features Creating Special or Unusual Safety or Environmental Problems.}

1. Plant/Worker safety is ensured by calculation of biological radiation protection, remote operation, emergency cooling and off-gas systems.

2. Off-gas system purifies off-gas from radionuclides and hazardous components to Russian State Sanitary Codes. Off-gas overall dimensions of the vitrification plant with glass productivity $75 \mathrm{~kg} / \mathrm{h}$ are $6 \mathrm{~m}$ in width, $10 \mathrm{~m}$ in length, and $6 \mathrm{~m}$ in height.

3. Secondary wastes produced at vitrification are low-level condensate from evaporatorconcentrator and off-gas system, nitric acid with concentration up to $120 \mathrm{~g} / \mathrm{L}$, spent filtering material from coarse sleeve filter, spent filtering material from HEPA filter, and spent catalyst. Solid waste produced can be vitrified in the same melter - cold crucible. 
FRENCH RESPONSE

(ANTOINE JOUAN)

C-9 


\section{Introduction}

The vitrification of high-level liquid waste produced from fuel reprocessing has been carried out industrially for over 20 years by COGEMA, with the dual objective of containment and reduction of the volume of waste. Based on preliminary experience gained since the early 1970s in the Marcoule Vitrification Facility, the process was implemented in the late 1980s in the R7 and T7 facilities of the La Hague plant. Both facilities are equipped with three lines having each a production capacity of $25 \mathrm{~kg} / \mathrm{h}$ of glass.

R \& D initially carried out at the CEA (the French Atomic Energy Commission) led to the choice of a two-step process, and the choice of a borosilicate glass. CEA backup allowed continuous improvement of the performance of the process and of the associated technologies. A recent development, implemented after ten years of operation of the facilities at La Hague, was the use of mechanical stirring in the melting pots in order to deal with higher noble metals and to boost the capacity of the vitrification lines.

So far, COGEMA's R7 and T7 facilities at La Hague have produced more than 6500 high-level glass canisters, representing around 2600 tons of glass and over 2700 million curies.

\section{The Cold Crucible}

To further enhance the performance of the vitrification lines of these facilities, COGEMA is aiming at the application of the vitrification process by direct induction in a cold crucible, by the year 2002 . The cold crucible technology will help overcome difficulties associated with corrosion and with the high temperatures. Its use will lead to a virtually unlimited equipment service life and great flexibility in dealing with different types of waste to be immobilized. In particular, the potentially very high specific powers induced into the glass bath will help to adjust the glass temperatures without any impact on the process equipments. 
Application of the cold crucible technology is aimed at the vitrification of very highly concentrated and corrosive molybdenum solutions from Uranium - Molybdenum fuel reprocessing at La Hague. The first $R$ \& $D$ on the Cold Crucible was carried out in the late 1980 s. The process and technology developments were based upon test platforms located at the CEA. These developments helped to demonstrate the overall throughput as well as the performances of the main technologies required, i.e. the glass pouring device, the off-gas treatment system and the electric power supply.

All of the results obtained to date are part of COGEMA's program to qualify the Cold Crucible technology for the vitrification at La Hague. . Start-up of a line equipped with a Cold Crucible in the R7 facility is scheduled for the year 2002 .

In parallel with developments carried out directly for COGEMA's operating facilities, the CEA has provided its support for the industrial implementation of the Cold Crucible technology for other nuclear and non-nuclear applications. The Cold Crucible technology is being presently implemented by SGN, COGEMA's engineering subsidiary, to process waste for two foreign customers. Two contracts have been awarded, one for the construction and commissioning of a vitrification unit for high level waste for ENEA (National Authorities for Italy's Atomic Energy) at Saluggia in Italy and a second for the construction of a cold R \& D pilot for KEPCO, South Korea's electrical utility: Hot start-up of the vitrification line in Italy is scheduled for 2002, and tests on the installation in South Korea will begin in late 1999.

\section{The Advanced Cold Crucible Melter}

Given the very good results demonstrated by the Cold Crucible technology, COGEMA has recently decided to develop the Advanced Cold Crucible Melter (ACCM) technology. This new design allows in increase in the melting capacity. It also makes it possible to vitrify the waste in a once-through process by liquid or solid feed of the melter with a high glass throughput capacity (more than $100 \mathrm{~kg} / \mathrm{h}$ per line liquid feed and more than $400 \mathrm{~kg} / \mathrm{h}$ with solid feed).

The ACCM technology preserves the advantages of virtually unlimited equipment service life, flexibility with respect to the waste to be treated, high capacity and minimum size, all advantages which inherently imply reduced costs. 
This ultimate development is particularly well adapted to the processing needs for the various High Level Waste streams in the United States.

\section{Conclusion}

The Advanced Cold Crucible Melter offers unique performances for the treatment of High Level Waste in USA. These outstanding features are highlighted hereafter :

\# High capacity

/ Both liquid feed and solid feed capabilities

$/ /$ No corrosion: virtually unlimited service life

/2 Flexibility with respect to the different types of waste to be immobilized

/I Flexibility with respect to the choice of glass formulation

L High waste loads (because of high temperatures and mechanical stirring)

I. Small size of the equipment

/ Dramatic reduction of the secondary waste generated by operations

/1 Low costs 


\section{Technical Questionnaire}

\section{A. System performance}

\section{i) Product quality}

Selection of a glass or ceramic formulation for waste immobilization must account for both waste characteristics and available technology.. The choice of a glass formulation and process optimization must be very closely linked in order to achieve high product quality and plant availability. In the following, several examples of products developed in France for various types of waste and for the range of technologies available are described.

\section{R7T7 glass for the standard hot crucible-based La Hague plants.}

The R7 and T7 facilities at La Hague are currently vitrifying high level waste solutions arising from the reprocessing of commercial high burn-up fuel in the UP2-800 and UP3 plants. The waste is in the (nitric) acidic form, with little added inert reagents (such as sodium, aluminum, iron). It is vitrified using the standard hot crucible process, at a temperature of $1150^{\circ} \mathrm{C}$. It holds a very high activity (predominantly ${ }^{137} \mathrm{Cs},{ }^{90} \mathrm{Sr}$ ) and significant amounts of noble metals. Waste loading: The wasteform is the "R7T7" borosilicate glass, designed to hold, at the maximum, $18.5 \%$ of radioactive waste oxides (fission products, actinides, noble metals and $\mathrm{Zr}$ fines), or equivalently to an overall maximum waste loading of $28 \%$. This limit has been set to avoid excessive heating of the glass during storage. The maximum $\beta \gamma$ activity at the time of vitrification is $760,000 \mathrm{Ci}$ per canister (each canister receiving about $400 \mathrm{~kg}$ of glass). The maximum contact dose rate at the time of production can be greater than $10^{6} \mathrm{rad} / \mathrm{h}$.

a) Durability : The R7T7 composition is very well known worldwide as being outstandingly durable, especially in the long term. Normalized releases using a powder test very similar to 7-day PCT are less than $1 / 10$ of the US acceptability criteria. 
b) Phase separation: No phase separation occurs.

c) Crystallinity : Due to the relatively low content of ( $\mathrm{Fe}, \mathrm{Cr}, \mathrm{Ni}, \mathrm{Mn}$ ) in the waste, R7T7 is not prone to extensive crystallization during melting, although its liquidus temperature for spinels is relatively high, around $1120^{\circ} \mathrm{C}$. The spinels that could be formed during melting are easily evacuated during glass pouring.

In addition, since the glass withstands a very high heat load, it has been specifically designed to avoid devitrification during storage. The maximum amount of crystals after very severe heat treatment (with respect to nucleation and growth) does not exceed $5 \%$ in the presence of noble metals. This devitrification does not have any impact on glass durability.

d) Waste homogenization capabilities : During the qualification process for the La Hague plants, waste homogeneity has been demonstrated through grab samples during pouring and destructive examination of containers. Homogeneity was fully satisfactory and no undissolved feed was observed.

Satisfactory quality of the glass has also been demonstrated through the examination of production samples obtained both at R7 and T7 plants. The glasses were homogeneous with no undissolved feed and their characteristics were in full agreement with the expected values. The residence time of the glass in the melter is in the range of some hours, which has been found to be enough for complete glass elaboration, provided that the temperature is sufficient.

\section{Glasses processed in the CCM for US applications}

Waste loading: Contrarily to all other traditional waste vitrification processes, the CCM allows processing waste at high or very high temperatures (greater than $1600^{\circ} \mathrm{C}$ if required). The CCM tolerates corrosive melts and is able to melt compositions that are too viscous for the traditional $1150^{\circ} \mathrm{C}$ melters. As a result, the limits for glass formulation can be greatly extended. More particularly, when the waste contains large amounts of refractory elements (such as zirconia or alumina), it is possible to increase the waste loading in comparison with more standard processes. The processing range extension can be such that, often, the waste loading is limited by other factors, such as 
intrinsic product quality, volatility considerations or container material.

The demonstration program carried out during the Hanford TWRS privatization phase $1 \mathrm{~A}$ is a good illustration of the flexibility brought on by the release of the temperature constraints with typical US-type HLW waste.

In the $1200^{\circ} \mathrm{C}$ to $1300^{\circ} \mathrm{C}$ temperature range, the actual waste loadings achieved in the pilots were as high as $44,5 \%$. In crucible melts, fully processable and acceptable glasses were prepared, with waste loadings of up to $52 \%$. Modeling studies have shown that, for one waste type, waste loadings as high as $58 \%$ could be achieved in the same range of temperatures. The limit in this case was product quality, since higher waste loadings would lead to the formation of nepheline upon glass cooling (the formation of nepheline in a glass is detrimental to the overall glass leach resistance).

a) Durability: the durabilities of all the glasses melted during the study largely exceeded the 7-day PCT criterion (sodium and boron releases were of the order or 0.2 to $0.3 \mathrm{~g} / \mathrm{m}^{2}$ ). On this respect, the possibility to melt at higher temperatures is favorable, since it allows decreasing of the amount of fluxes (and especially alkalis, known to be detrimental to glass durability) and increasing of the amount of glass formers (silica, alumina, zirconia) in the glass.

b) Phase separation: the degree of phase separation depends on the waste to be processed and can be, among others, adjusted through glass formulation. The use of a CCM can only be advantageous, since it tolerates corrosive fluids and offers increased flexibility for waste glass formulation.

c) Crystallinity: In traditional, large size ceramic-lined melters, insoluble crystalline phases, although not detrimental to glass quality, are usually avoided since they may generate serious operating problems when they are allowed to accumulate. Usually, this phenomenon is accounted for by formulating glasses with liquidus temperatures lower than the operating.melter temperature by about $100^{\circ} \mathrm{C}$.

Even with this conventional approach, the possibility to operate the $\mathrm{CCM}$ at higher temperatures already offers the possibility to process glasses with higher liquidus temperatures (and thus increased $\mathrm{Cr}, \mathrm{Fe}$ and $\mathrm{Ni}$ contents). 
In fact, the CCM is expected to be much more tolerant than traditional large size ceramic melters are towards the formation of spinels and chromite in the melts, since it combines several favorable features:

1/ Short residence time of the melt in the melter,

/I Efficient stirring of the melt,

/ Pouring through a bottom drain.

As a result, it is expected that the glass formulation philosophy towards crystallization could become less stringent than the present conventional criteria for LFCM.

Until now, and with no specific precautions, no crystal accumulation problem has ever been encountered during the numerous tests performed with the pilot CCMs in France (although the feeds tested may not have been the most demanding in this respect).

During the Hanford demonstration tests, one of the glasses tested had a liquidus temperature of around $1050^{\circ} \mathrm{C}$ for spinel. No extensive crystallization or accumulation was noted in the pilot melter during a continuous run at $1200^{\circ} \mathrm{C}$.

d) Waste homogenization capabilities: the CCM can be operated with efficient stirring, which helps homogenizing composition and temperatures. With adequate temperature and stirring, the required residence time in the melter to obtain satisfactory, fully digested glasses can be as low as a few hours.

\section{Development of other materials to be processed in the}

\section{CCM}

Borosilicate glass is currently the only qualified matrix for immobilizing high-level or long-lived waste. However, it may not be the best solution for every situation : with some waste compositions, the requirement to produce a glass limits significantly the achievable waste loading. The use of crystalline (ceramic, glass-ceramic) matrices could allow much higher waste loadings.

For a long time, the industrial production of crystalline materials in a nuclear environment has been considered difficult, since it usually involved high pressures and high temperatures. CEA is now 
investigating the feasibility of producing these types of matrices through fusion using the CCM.

Several tests have already been performed successfully in the Marcoule laboratories and pilots, to formulate and produce various glass-ceramics. The melting temperatures ranged from $1300^{\circ} \mathrm{C}$ to $1600^{\circ} \mathrm{C}$. Studies are under way to optimize the production process, and also to characterize the leach behavior of the materials, both in deionized water and in environments simulating repositories.

ii) Processing rate - Identify maximum glass processing rate. Specify all assumptions. Identify total quantity of glass produced per plant operating life.

COGEMA has 20 years of industrial experience and operates seven vitrification lines in the field of high-level liquid waste vitrification.

\section{AVM Plant (Marcoule Vitrification Plant)}

The CEA's successive developments from the initial two-step vitrification process (calcination followed by vitrification) led to the active commissioning in 1978 of the world's first industrial HLLW vitrification facility, the AVM (Marcoule Vitrification Plant).

Equipped with a vitrification line including an induction heated melter (Standard Hot Crucible) with a nominal capacity of $15 \mathrm{~kg} / \mathrm{h}$ of glass, the AVM has so far produced more than 1260 tons of glass corresponding to the immobilization of 500 million $\mathrm{Ci}$ in over 3500 glass canisters.

\section{R7/T7 Plants (La Hague Vitrification Plants)}

Based on the AVM experience, the R7/T7 vitrification plants at $\mathrm{La}$ Hague were scaled up and dimensioned to match the plant's spent fuel reprocessing capacity. Hence each plant produces $50 \mathrm{~kg} / \mathrm{h}$ of glass by means of three vitrification lines (two in service and the third on standby; in some operating phases, all three lines run in parallel). 
The melter of each of the vitrification lines of $\mathrm{R} 7$ and $\mathrm{T} 7$ has a nominal capacity of $25 \mathrm{~kg} / \mathrm{h}$.

Since the commissioning of the R7 (1989) and T7 (1992) vitrification plants, more than 2600 tons of glass has already been produced at La Hague for a conditioned activity of 2710 million $\mathbf{C i}$ in over 6500 glass canisters.

\section{Cold Crucible Melter Applications}

To further improve the performance of the vitrification lines of these plants, while simplifying the initial process, COGEMA turned toward the vitrification process by direct induction in a cold crucible (Cold Crucible Melter), which was ideal for dealing with problems of corrosion at high temperature.

The cold crucible melter is now fully qualified, and a vitrification line of the R7 plant equipped with a cold crucible is scheduled to start in operation in 2002.

Developments carried out jointly by the CEA and the COGEMA Group for the industrial development of this technology have led to:

ll in the nuclear field, two ongoing projects using cold crucibles with direct feed:

$\checkmark$ the first for ENEA, capacity $15 \mathrm{l} / \mathrm{h}$ for HLLW vitrification in 2002 at Sallugia (Italy)

$\mathcal{~ t h e ~ s e c o n d , ~ w i t h ~ c a p a c i t y ~ o f ~} 50 \mathrm{~kg} / \mathrm{h}$ for the commissioning in 1999 of a cold waste treatment pilot facility for the South Korean power company KEPCO.

In in the non-nuclear field, the commissioning in 1995 and 1998 of two industrial enamel production furnaces using oxides, with capacities up to 100 and $400 \mathrm{~kg} / \mathrm{h}$ respectively, that have given the operators full satisfaction,

The results and performance already demonstrated by the cold crucible vitrification technology led COGEMA to develop the Advanced Cold Crucible Melter (ACCM). 
This technology allows high glass throughput capacity (over $100 \mathrm{~kg} / \mathrm{h}$ with liquid feed and more than $400 \mathrm{~kg} / \mathrm{h}$ with solid feed) in a one-step process, while benefiting of all of the advantages of the cold crucible technology:

// equipment service life,

/1 flexibility in the waste to be treated, both in terms of waste composition and formulation of the containment matrix, // high capacity and compact size.

All these features imply a significant cost reductions.

The non-nuclear applications carried out in parallel are aimed at glass melting capacities of around 1 metric ton per hour.

\section{iii) Range of waste handling capabilities}

\section{a) Incorporation of semi-volatiles}

The main semi-volatile radioelement is cesium. Ruthenium may also fall into this category. Borosilicate glasses can intrinsically incorporate the element $C s$ in their matrix. This requires recycling the volatile portion of the cesium in the system after having trapped it in wet scrubbers.

The La Hague vitrification plants have largely demonstrated this possibility. For example, the $15 \%$ of $C s$ volatilized is recycled to the process after being trapped in three equipments : a first wet scrubber, a condenser and a scrubbing column. Less than one millionth of the Cs fed to the process escapes scrubbing and is finally recovered in the HEPA filters. The Decontamination Factor until the wet scrubbers is higher than $10^{6}$ and the total decontamination factor for off-gas treatment is about $10^{10}$.

Most of the volatiles trapped in the first scrubber is continuously recycled towards the calciner at a rate of about $10 \%$ of the entering solution, and the remainder is batch recycled after evaporation of the condensates and the wash solution from the last column. 


\section{b) Ability to handle insolubles and conductive compounds}

Elements which are insoluble in the glass, such as noble metals, no longer pose any problem in a stirred glass bath. The La Hague plants have demonstrated this, by incorporating $3 \%$ of noble metals in the FP glass today.

The absence of electrodes in a cold crucible also eliminates any risk of electrical shorting. If any settling occurs in the cold crucible despite stirring, bottom drainage would prevent any holdup in the crucible.

\section{c) Ability to handle slurry feeds}

The CEA and COGEMA have experience in handling slurries of glass frit and of noble metals, for which COGEMA in particular has developed standards which are applied in the R7 and T7 plants at La Hague.

\section{d) Ability to handle fissile materials}

The actual quantity of fissile material incorporated in the "R7/T7" glass at $\mathrm{La}$ Hague is very small, with a $\mathrm{PuO}_{2}$ content not exceeding $0.025 \%$ by weight.

The borosilicate glasses cannot incorporate more than 1 to $2 \% \mathrm{PuO}_{2}$ in their structure. The use of a cold crucible to achieve this, with its mechanical stirring, would guarantee the best possible uniformity.

To incorporate larger amounts of $\mathrm{PuO}_{2}$ or oxides of other actinides, it is necessary to use other glass or glass-ceramic formulas. These can only be produced at very high temperatures. Small cold crucibles can be used to prepare materials of the zirconolite type at over $1500^{\circ} \mathrm{C}$, containing more than $10 \% \mathrm{PuO}_{2}$ while overcoming the problem raised by criticality.

\section{e) Identify range of glass compositions}

We have experience today in using a cold crucible to melt and pour a wide variety of molten salts, glasses and glass-ceramics :

\# Highly corrosive glasses (e.g. phosphate) and molten salts (e.g. sodium borate) are easily prepared in a cold crucible, which can reach very high temperatures. 
/ Different types of glass-ceramic can also be prepared.

It is nonetheless preferable:

$1 /$ to remain within the ranges of electrical resistivity from 2 to 15 ohm.cm,

$/ /$ to limit the viscosity of the poured glass to 150 poises, although the variable opening of the pouring valve orifice allows operation at higher viscosities.

\section{f) Identify components or feed properties}

Regardless of the technology employed, elements like Mercury and Iodine are virtually unincorporable in conventional glass matrices. Anions like $\mathrm{Cl}$ and $\mathrm{S}$ also raise problems because the matrices can only accept limited quantities of them $(<1 \%)$.

The presence of organic compounds in the feed solution can also lead to problems depending on the quality and quantity of these compounds.

The use of a cold crucible nevertheless offers the following two advantages:

it eliminates the risk of corrosion due, for example, to sulfates or chlorides, thanks to stirring, it also drastically reduces risks linked with heterogeneities in the bath temperatures or composition.

\section{g) Range of properties}

Reference can be made to the answer to question iii e) concerning viscosity and electrical conductivity.

The risks of crystallization are related to the glass composition, the residence time in the melter, and the operating temperature. 
For a given composition, the cold crucible offers the best chance of overcoming these risks:

$/$ by virtue of its design, it minimizes residence time, $/ /$ by offering the possibility of operating at elevated temperature, $1300^{\circ} \mathrm{C}$ or more.

Moreover, any crystals formed can be redissolved by rising the temperature. 


\section{B. Pouring}

Since the start of industrial operation, COGEMA has always operated batch pouring processes. The pouring devices have hence been designed to be able to perform a great number of pour cycles, each pour cycle comprising start of glass flow, control of pour rate, and stop of glass flow.

The cumulated experience in COGEMA's different vitrification facilities amounts to about 23500 pouring cycles.

Average pour frequency and pour rate are closely linked. These pouring parameters are set in order to obtain satisfactory filling conditions of the glass canister which in turn depend on the transient thermal conditions during the pouring stage. Depending on the glass temperature, ambient conditions in the pour cell and canister's dimensions, a minimum value of the pour rate can be specified. For a given capacity, this implies that minimum and maximum values of the pour frequency can also be specified.

Typical orders of magnitude of pouring parameters for the R7 and T7 plants are the following:

// pour batch : approximately $200 \mathrm{~kg}$,

/ pour rate : approximately $400 \mathrm{~kg} / \mathrm{hr}$,

// pour frequency : approximately one pour cycle every 8 hours.

The slide valve developed for the cold crucible technology is derived from COGEMA's past experience. Since the cold crucible's lifetime is virtually unlimited, the slide valve has been designed to be compact, modular and maintainable. It's total weight is less than $100 \mathrm{~kg}$ and the total time required for replacement of the valve module is typically less than two days. 


\section{Noble Metals}

At COGEMA's La Hague vitrification facilities, the waste being processed has a high content in noble metals which tends to lead to the precipitation of $\mathrm{RuO} 2$ and metallic aggregates. The specified values for the noble metals content in the glass is of $3 \%$. This value could be increased since the process was qualified with a noble metals content of $3,5 \%$.

Whatever technology considered (standard hot crucible or cold crucible melter) heat is generated by induction. Therefore, there are no electrodes and no shorting problems have ever been encountered.

COGEMA's crucibles are equipped with stirring devices which are efficient in limiting any settling of noble metals.

Short residence times and bottom pouring are also very positive factors in order to limit any settling of noble metals. 


\section{REDOX and foaming}

\section{R7 and T7 facilities at La Hague}

The La Hague process is a two-step process.

The nitric acid ( $2 \mathrm{M})$ solution is fed to a rotary calciner, where it is progressively heated in the presence of air up to $600^{\circ} \mathrm{C}$.

If needed, aluminum nitrate is added to the feed prior to calcination, in order to avoid sticking in the calciner (melting of NaNO3). Sugar is added to the feed prior to calcination to reduce some nitrates and to limit ruthenium volatility.

At the outlet of the calciner, the feed is still in the oxidized state, with significant amounts of nitrates left. The calcine falls directly into the melter together with frit added through a separate feed.

The glass is fully oxidized, with almost no Fe (II).

In these conditions, foaming or metals (other than noble metals) precipitation have never been experienced at La Hague.

The contains holds only small amounts of multivalent elements such as $\mathrm{Fe}$ and $\mathrm{Cr}$, since they only arise from equipment corrosion.

\section{Hanford demonstration}

The proposed process for the Hanford demonstration also involved a two-step calcination / vitrification process.

During the pilot runs, the feed represented two typical Hanford sludges acidified with nitric acid to $1 \mathrm{M}$ free acid.

Calcination was performed in the same way as above, leaving some nitrates in the calcine.

Again, the glasses melted without foaming and were oxidized. 
In this case, the contents of multivalent elements were typical of some US tank wastes $\left(\mathrm{Fe}_{2} \mathrm{O}_{3}\right.$ contents in the glass up to $14 \%, 0.15 \% \mathrm{Cr}_{2} \mathrm{O}_{3}$, $0.4 \% \mathrm{MnO}_{2}, 0.10 \% \mathrm{CeO}_{2}$ ).

It should be noted that, in the proposed process, the melter was operated at 1200 to $1300^{\circ} \mathrm{C}$, and equipped with an efficient stirring device.

\section{Liquid feeding}

The tests performed with liquid feeding of a CCM operated at $1200^{\circ} \mathrm{C}$ and equipped with a mechanical stirrer did not lead to foaming.

Some tests were performed with sugar additions to decompose sulfates.

\section{Suggested solutions}

It is obvious from these results that separate oxidizing calcination is probably one way to avoid foaming. However, the implementation of a calciner may not always be desirable or possible.

The above results also suggest that the geometrical configuration of the glass bath in the CCM and the adapted stirring device might be favorable to mitigate foaming problems. It might also be interesting to test various operating modes regarding the interactions of stirring and cold cap. 


\section{E. Technical Maturity}

\section{i) Availability of the melter system on a production scale}

The availability factors of COGEMA's vitrification plants, calculated on 250 days in operation are of about $66 \%$.

This figure takes account of maintenance shutdowns of the vitrification lines for periodic servicing of the calciner and the induction heated melter (standard hot crucible).

The future installation of a cold crucible in a vitrification line will increase the availability factor:

ii) Demonstrated scale operation - identify largest scale of operation (kg glass/h) demonstrated and/or whether proof of principles has been established and at what scale, operating conditions and feed type

The implementation of an industrial vitrification process demands the design, development and qualification of the process and the associated technologies at different scales, as well as the capitalization of past industrial experience.

\section{AVM/AVH Plants}

The industrial achievements of the AVM, R7 and T7 vitrification plants reflect COGEMA's maturity and industrial expertise in vitrification, with over 3850 tons of glass produced (representing over than 3210 million $\mathrm{Ci}$ and 10000 canisters).

Development, improvement and qualification of this vitrification process were carried out on different $R \& D$ platforms of the CEA, reproducing the equipment and vitrification process of Marcoule and La Hague plants at different scales (various prototypes, scales 1:10, $1: 5,1)$. 


\section{Cold Crucible and Advanced Cold Crucible Melter}

Based on the experience gained with the development and optimization of the vitrification process in the Marcoule and La Hague plants, and in order to increase vitrification capacity and availability factors, industrial developments initiated by the COGEMA Group in the area of cold crucibles are based on the use of the CEA's different $R \& D$ platforms.

The CEA has CCM and ACCM pilot facilities, on which technological and process developments are currently carried out :

The CCM platforms are on duty since the late 1980 s, and the CCM is qualified to go on stream.

The ACCM platforms are in operation since 1995.

The specific features of each of these platforms helps fully optimize development programs:

\begin{tabular}{|c|c|c|c|c|}
\hline $\begin{array}{c}\text { Pilot } \\
\text { (diameter } \\
\text { in } \mathbf{m m} \text { ) }\end{array}$ & $\begin{array}{l}\text { Liquid Feed } \\
\text { Glass Capacity } \\
(\mathrm{kg} / \mathrm{h})\end{array}$ & $\begin{array}{c}\text { Solid Feed } \\
\text { Glass Capacity } \\
(\mathrm{kg} / \mathrm{h})\end{array}$ & & Application \\
\hline CCM 300 & $x$ & 15 & ״ & $\begin{array}{l}\text { Organic or } \\
\text { inorganic } \\
\text { compounds } \\
\text { vitrification } \\
\text { Volatility and off- } \\
\text { gas treatment } \\
\text { studies }\end{array}$ \\
\hline $\begin{array}{l}\text { CCM } 550 \\
\text { CCM } 650\end{array}$ & 15 & 60 & $\not$ & $\begin{array}{l}\text { Formulation and } \\
\text { technology } \\
\text { development }\end{array}$ \\
\hline $\begin{array}{l}\text { ACCM } 600 \\
\text { ACCM } 1000\end{array}$ & $\begin{array}{l}15 \\
50\end{array}$ & $\begin{array}{l}60 \\
120\end{array}$ & ״ & $\begin{array}{l}\text { Process and } \\
\text { technology } \\
\text { development }\end{array}$ \\
\hline ACCM 1400 & 100 & 400 & $\not 1$ & $\begin{array}{l}\text { Full-scale } \\
\text { technology } \\
\text { development }\end{array}$ \\
\hline
\end{tabular}

The duration of the test campaigns can be adjusted to the conditions and tested parameters (from one day to several weeks). 


\section{F. Facility/System INTEGRATION}

\section{i) Feed preparation requirements.}

COGEMA's industrial experience is mainly based on the two-step calcination / melting process, with separate feeds for acid solution and glass frit. The CEA has also some experience in feeding the glassformers as a suspension in water. The feed preparation requirements depend mainly on the acidic or alkaline nature of the HLW solution to be treated.

For an acid feed, it is more appropriate to separate liquid waste solution from solid glass formers : this helps to avoid sodium addition while making transfer of solution easier and reducing the volume of glass product. In this case, homogenization of glass product is ensured by stirring the melt.

Alkaline waste can be mixed with glass formers before feeding. Addition of reductants may be needed for redox adjustment.

In both cases, maximum solids content in the slurry is limited by the ability to transfer and meter the suspension.

\section{ii) Off-gas system requirements}

Whatever the process considered, off-gas requirements mostly depend on feed characteristics.

The lower temperature on the dome with a CCM helps limit entrainments and solid deposits.

The first off-gas treatment unit must be of the liquid scrubber type and located as near as possible to the melter gas exit. Downstream treatment depends on the feed composition and the release requirements. 


\section{iii) Melter trains}

The number of melter trains depends on :

L the required capacity of the plant,

Æ. feed concentration,

Ls plant layout.

For a circular crucible with a diameter of approximately $1,5 \mathrm{~m}$, the glass capacities expressed per melter train are approximately the following :

$/ 100 \mathrm{~kg} / \mathrm{hr}$ (if the melter is liquid fed with typical values of waste concentration in the feed)

// $400 \mathrm{~kg} / \mathrm{hr}$ (if the melter is solid fed)

\section{iv) Plant service requirements}

For a liquid fed cold crucible melter with typical values of waste concentration in the feed and a glass capacity of $100 \mathrm{~kg} / \mathrm{hr}$, the service requirements would be the following :

total electrical power installed : approximately $800 \mathrm{~kW}$, cooling water : approximately $800 \mathrm{~kW}$, air : to be defined, no steam.

v) Melter dimensions and weight, special requirements for melter maintenance and replacement

Typical dimensions for a liquid fed cold crucible melter with a capacity of $100 \mathrm{~kg} / \mathrm{hr}$ are the following :

L diameter : less than 2 meters (when taking into account inductor coil and cooling systems),

// height : approximately 2 meters (when taking into account inductor, cooling systems and dome).

Specific equipments for off gas treatment could require extra volume within immediate environment of the cold crucible. 
The design of the ACCM is modular. All the components of the ACCM are compact and maintainable.

The crucible itself and its supporting slab are compact in dimensions and have a virtually unlimited lifetime. They make up the largest component of the ACCM platform and can be handled with standard equipments having a capacity of about 5 tons.

All other sub-components are much smaller in dimensions and weight (pouring valve, inductor coil, control systems on dome, feed systems . on dome, off gas exhaust systems, ...).

II The different sub-components are designed to be maintained or replaced in a remote environment.

LT The weight of each sub-component is typically less than 1 ton.

The general principle applied for maintenance is that the system can be completely disassembled from the top down with manipulators and cranes. Maintenance operations are performed remotely with remote handling equipment and while the crucible and most of its subcomponents remain in cell. This approach facilitates replacement of used equipment and makes it possible to benefit in a progressive and cost sensitive manner from feedback experience.

\section{vi) Ability to operate in a remote environment. Identify}

The Cold Crucible Melter is specially designed to operate in a remote environment for High Level Waste processing.

Design concept is based on principles already proven on High Level Waste vitrification systems and other industrial High active processing facilities operated by COGEMA.

Design criteria were selected :

$\mathscr{L}$ to meet performance criteria,

$\mathscr{L}$ to ensure cost effective production availability (reliability, maintainability),

$/$, under optimum operating and safety conditions, to minimize personnel exposure, environmental impact and solid secondary waste generation. 
vii) Ability to fill / handle 2'x10' tall canisters

During the Hanford demonstration, the complete filling cycle of the standard 2'x10' canister was studied.

The studies showed that for a glass temperature of $1200^{\circ} \mathrm{C}$, the consequences of the thermal load are acceptable with respect to the filled canister specifications and that significant margins are still available.

For higher temperatures similar studies should be performed. 


\section{G. Operability}

\section{i) Easy of control - describe required controls}

The two most important parameters governing melter operation are the voltage and current.

Their measurement is conventional and raises no particular problems.

Level and temperature measurements of the glass bath are provided for.

Only the temperature measurement requires the presence of an uncooled metal rod in the bath. Its life is hence inherently limited and it is interchangeable.

\section{ii) Remotability must be adaptable to a remote, radioactive environment.}

The Cold Crucible Melter system from the start has been specially designed to operate in a remote, radioactive environment, in order to minimize personnel exposure in all circumstances.

Operation is automated and remotely performed from a centralized control room.

A computerized data management system is provided for continuous monitoring of the process parameters and the product quality, as well as to detect all abnormal deviations and to help to correct (computer aided operation).

All the operations (normal operation, special operation, maintenance operations) are fully remotized. 
iii) Reliability - Identify on-line efficiency and demonstrated maximum

Experience already gained has proven that the Cold Crucible Melter is the most reliable, compared to all the other waste vitrification systems : no corrosion, no wear, and no electrodes. It must be noted that the development of the Cold Crucible Melter was performed in continuity with the vitrification development program in France since the early sixties.

Plant availability is a function of process and equipment reliability, as well as maintenance capabilities. Careful attention is given to reliability and flexibility of the process to avoid out-off-spec products. This implies sufficient margins and adequate process control in order to respond satisfactorily to minor disturbances.

In terms of process flexibility, the ability to operate at high temperature, and the stirring device of the Cold Crucible Melter provide significant advantages.

Moreover, the highest achievable reliability is requested for components, in order to minimize the maintenance operations, because maintenance is always costly, restraining and waste producing.

\section{iv) Maintainability - Describe normal maintenance requirements}

As already described, the Cold Crucible Melter has been designed to be fully remotely maintained.

Such equipment is designed in modular form to facilitate remote maintenance through replacement of complete sub-components.

Particular attention is given to facilitate access to sub-components considered to be the least reliable, such as motors and monitoring devices.

Remote maintenance is performed in-cell with cranes and remotely operated tools, using master-slave manipulators or servo manipulators.

Each sub-component is compact and easy to replace remotely. 
The volume of secondary wastes from maintenance operations is thus minimized. Pieces of worn equipment are generally of small size, can be easily splitted for conditioning in glass type containers.

The clogging risk is taken into consideration and countermeasures are provided where necessary.

\section{v) Estimated lifetime}

The CCM is not subject to electrode failure or refractory corrosion and therefore the crucible itself and its supporting slab have already a virtually unlimited lifetime. This point is confirmed from the cumulated experience of tests platform and industrial facilities.

Some components such as the temperature probe are expected to have . a limited lifetime. Such equipment is designed to be remotely maintained or replaced. The duration of these operation can range from a few hours to a few days. 


\section{H. Features creating special or unusually safety or environmental problems}

\section{i) Plant/Workers Safety}

The main safety requirements concerning the $\mathrm{CCM}$ are identified on the basis of the other types of melter.

Only the proximity of water and glass can cause an incident in case of failure of the water circuit near the melter.

Molten glass-water interaction studies have shown that, even if injected at high pressure into the bath, the mass of fragmented glass is very small, and that the glass solidifies very rapidly. The poor thermal conductivity of the glass limits any overpressure and the high heat of vaporization of the water helps freeze the bath immediately.

\section{ii) Identify environmental remediation requirements for special or significant waste stream}

The process is able to produce waste-forms in compliance with existing regulations or specifications, such as the WAPS for HLW, TCLP requirements for mixed or hazardous waste or the WIPP specifications (Contact Handle or Remote Handle) for TRU waste, according to the nature of the waste stream.

The Hanford demonstration provides one example of such compliance for HL tank waste. The wasteforms contain no organics. They are inert chemically and dry. Durabilities of glasses are in the same range or sometimes better than those of glasses made using other processes (due to the possibility to melt at high temperature). The first results on crystalline waste forms indicate that, for most matrices, good durabilities can be achieved. 
iii) Off-gas - extent of system required to remediate off-gas so it can meet site release rates and Clean Air Act requirements for Nox, radionuclides,etc;

To be defined

\section{iv) Generation of secondary waste streams}

The secondary waste streams can be classified in 2 categories:

1) Liquid waste. These waste may arise from several origins (off-gas treatment, decontamination operation...):

The liquid waste management policy in France favors recycling into the process, either directly or after extensive concentration/decontamination operations.

The basis for the aqueous waste treatment scheme relies on segregation of the effluents according to chemical and activity contents and implementation of evaporating capacities.

Most of the aqueous effluents are thus separated into a low activity fraction and a concentrated fraction holding most of the activity, which is routed to the vitrification facility.

This method has proven to be very efficient at La Hague with a significant decrease of both the volume and the level of activity of the ultimate residues, and only has a negligible impact on the HLW glass volume.

2) Solid waste generated during operation: This can comprise contaminated tools, failed equipment, or filters, rags, debris, ...

According to the waste management policy of a given site, this waste can be decontaminated, sorted and preconditioned prior to packaging.

Over the whole COGEMA complex, and especially at the La Hague facilities, efforts have been focused for several years on the minimization of the volume of conditioned solid waste.

These efforts encompassed all the aspects of waste generation and management, from plant and equipment design, to the development of 
specific repair techniques or to the implementation of rigorous sorting and decontamination of the waste at the source. The design and operation techniques that allow obtaining such a low volume of highly contaminated waste are applied for all the facilities designed or operated by the COGEMA group.

One cornerstone of this policy is the design of large equipment from small, independent modules that can be removed and replaced separately, through remotable connections. This provides the following advantages:

$/ /$ Possibility to design equipment with parts having lifetimes in accordance with their use (some parts, subject to wear, can be replaced more often than structural parts, for instance).

״. Easy decontamination,

// Easy conditioning for final disposition.

The CCM is designed in several modules, the heaviest of which weighs around $1000 \mathrm{~kg}$. It should be noted that the materials of the modules are such that most of the glass can be removed prior to packaging, since the glass does not stick to the cooled walls.

The glass can then be recycled easily in the repaired or new melter.

The remaining metal components display low, easy to remove contamination. Pieces of worn equipment are generally of a small size, could be considered as low activity wastes or can be, when necessary, easily split for conditioning in glass type containers.

Based on our current hypotheses for the replacement of equipment having limited lifetime, it is expected that the overall mass of secondary waste generated by melter train should be very low due to the general wear resistance of the CCM. 


\section{WEST VALLEY RESPONSE (STEVE BARNES)}




\section{A. WVDP Vitrification System Performance}

i. Product quality - The current reference glass for a vitrification plant is a borosilicate composition that contains typically about $25 \%$ waste on an oxide basis. The nominal processing temperature for this glass is $1150^{\circ} \mathrm{C}$. If your melter could incorporate more waste into the glass or operate better with a different composition, the alternate glass must meet the specifications listed below.

a. Durability - must be more durable than the reference glass, i.e., perform better than the reference glass for a 7-day Product Consistency Test (PCT)

Average waste loading to date (6/96 - 4/99): $30.4 \%$

Average PCT Performance Estimate (7 day test)

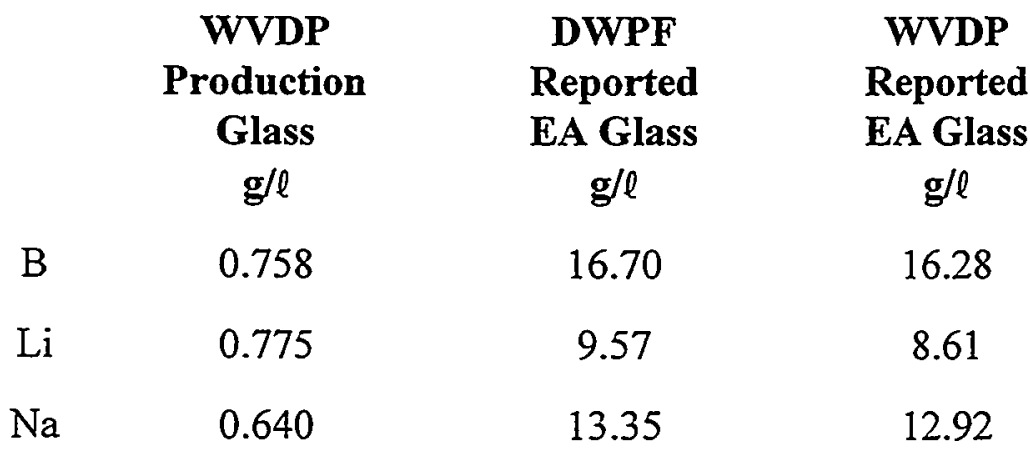

b. Phase Separation - Identify degree of phase separation, potential stratification in the melter, and potential affect on durability

No phase separation/stratification has been observed during testing with reference glasses at the WVDP site. $\mathrm{A} \mathrm{Ca}_{3}\left(\mathrm{PO}_{4}\right)_{2}$ phase was observed during very early, non-radioactive glass development tests at PNNL which was resolved by moving to a low calcium zeolite for waste pretreatment (IE-95 $\Rightarrow$ IE-96). Approximately $100 \mathrm{~kg}$ refractory corrosion spinel/glass mixture was found at bottom of FACTS melter at the end of campaign.

c. Crystallinity - Identify potential for glass crystallization and any potential effects on melter operation or glass durability

Canistered glass product is projected to contain less than $2 \%$ (volume) of iron/chromium/manganese spinel crystals based on testing. No other crystalline phases were observed in test glasses although small quantities of noble metal phases would be expected. Noble metals represent approximately $0.13 \mathrm{wt} \%$ of final glass product. 
d. Waste Homogenization - Identify potential for undissolved feed. Identify glass residence time

Testing indicated that the unreacted feed cold cap and the melter were effectively two well-mixed tanks in series. No unreacted feed was detected during cold operations tests. Mean glass residence time is approximately 60 hours.

ii. Processing Rate - Identify maximum glass processing rate.

a. Identify total quantity glass produced per plant operating life

Maximum Glass Production Rate: $\quad 55 \mathrm{~kg} / \mathrm{h}$

Average Glass Production Rate: $\quad 35 \mathrm{~kg} / \mathrm{h}$

Total radioactive glass produced through April 1999: $\quad \sim 495,000 \mathrm{~kg}$

Estimated Glass at Completion: $560,000-600,000 \mathrm{~kg}$

(Includes Tank Farm \& Facility Flushes)

\section{iii. Range of Waste Handling}

a. Incorporation of Semi-Volatiles - Ability to incorporate/immobilize radionuclides and problem chemical components, required recycle ratios and off-gas system loads

WVDP waste was pretreated to remove most of both the sodium used to neutralize the acidic waste stream and the sulfur resulting from the PUREX process. This reduced the anticipated glass by over an order of magnitude.

The process is designed with a wet scrubber as the first off-gas cleaning component. The scrub solution from this scrubber and the solution from canister decontamination are recycled into each new waste slurry feed batch.

The wet scrubber is followed by parallel stream combinations of high-efficiency mist eliminator (HEME) and high-efficiency particulate air filter (HEPA). The HEME's have been flushed (with the flush being recycled to the high-level waste (HLW) slurry feed), but no replacement of any of these filter elements has been needed to date. 


\begin{tabular}{|c|c|c|c|c|c|}
\hline \multicolumn{6}{|c|}{$\begin{array}{c}\text { Range of Glasses Processed by WVDP Melters, } \\
\text { Based on Feed Batch Chemistry }\end{array}$} \\
\hline & \multicolumn{2}{|c|}{$\begin{array}{l}\text { Nominal FACTS } \\
\text { Compositions }\end{array}$} & \multicolumn{3}{|c|}{$\begin{array}{l}\text { Radioactive Feed } \\
\text { Composition }\end{array}$} \\
\hline & Min $w t \%$ & Max wt\% & Min & Nominal & $\operatorname{Max}$ \\
\hline $\mathrm{Al}_{2} \mathrm{O}_{3}$ & 2.83 & 6.50 & 5.42 & 6.00 & 6.46 \\
\hline $\mathrm{B}_{2} \mathrm{O}_{3}$ & 9.26 & 12.89 & 11.47 & 12.89 & 14.63 \\
\hline $\mathrm{CaO}$ & - & -- & 0.36 & 0.48 & 0.60 \\
\hline $\mathrm{Fe}_{2} \mathrm{O}_{3}$ & 11.31 & 12.16 & 10.73 & 12.02 & 13.14 \\
\hline $\mathrm{K}_{2} \mathrm{O}$ & 3.18 & 5.00 & 4.48 & 5.00 & 5.60 \\
\hline $\mathrm{Li}_{2} \mathrm{O}$ & 2.71 & 3.71 & 3.28 & 3.71 & 4.02 \\
\hline $\mathrm{MgO}$ & -- & -- & 0.81 & 0.89 & 1.04 \\
\hline $\mathrm{MnO}$ & --- & --- & 0.73 & 0.82 & 0.93 \\
\hline $\mathrm{Na}_{2} \mathrm{O}$ & 8.00 & 11.17 & 7.43 & 8.00 & 8.66 \\
\hline $\mathrm{P}_{2} \mathrm{O} 5$ & --- & --- & 0.78 & 1.20 & 1.41 \\
\hline $\mathrm{SiO}_{2}$ & 40.93 & 44.90 & 39.27 & 40.98 & 42.50 \\
\hline ThO2 & 3.34 & 3.60 & 1.36 & 3.56 & 3.86 \\
\hline $\mathrm{TiO}_{2}$ & 0.77 & 0.98 & 0.64 & 0.80 & 0.88 \\
\hline $\mathrm{UO}_{3}$ & 0.55 & 0.63 & 0.33 & 0.63 & 0.79 \\
\hline $\mathrm{ZrO}_{2}$ & 0.27 & 1.32 & 1.21 & 1.32 & 1.54 \\
\hline $\mathrm{Cr}_{2} \mathrm{O}_{3}$ & -- & - & - & 0.14 & -- \\
\hline $\mathrm{PdO}$ & -- & -- & $-\cdots$ & 0.03 & -- \\
\hline $\mathrm{PhO}_{2}$ & $\cdots$ & $\cdots$ & $\cdots$ & 0.02 & - \\
\hline $\mathrm{RuO}_{2}$ & -- & -- & -- & 0.08 & - \\
\hline $\mathrm{SO}_{3}$ & - & - & $\cdots$ & 0.23 & -- \\
\hline
\end{tabular}


b. Ability to handle insoluble and conductive compounds - Identify impact of compounds on melter performance

The glass composition was tailored for the WVDP waste to maintain solubility of the waste components, with the exception of the noble metals. There are no provisions for removing an insoluble layer at the glass surface or a slag from the melter floor short of an evacuated canister. Experience to date indicates retention of approximately $5 \%$ of the noble metals in the melter. These noble metals deposits have resulted in a reduction of the resistance between the side to bottom electrode pairs from 150 to $30 \mathrm{ohms}$ and from 300 to $60 \mathrm{ohms}$ for the side electrode to side electrode pair. The noble metals accumulation is not expected to be melter life limiting at WVDP.

c. Ability to handle slurry feeds - Identify maximum solids content that can be processed

The sy'stem is designed to be slurry-fed. Over $900,000 \ell$ (approximately 250,000 gallons) of waste slurry has been vitrified, producing 238 canisters. The total solids content of the feed has ranged up to $63 \mathrm{wt} \%$ and glass yields from 290 to 630 grams glass per liter of feed slurry.

d. Ability to handle fissile materials (i.e., little or no accumulation in the melter)

The WVDP glass composition indicted no fissile material phase separation in the test glasses.

e. Identify range of glass compositions or characteristics known or expected to be compatible with system performance.

The range of glasses processed in this melter design is shown in the table above.

f. Identify components or feed properties that cannot be handled or require special treatment.

As discussed in part $\mathrm{b}$ above, feed components that would lead to phase separation in this melter, or require processing temperatures not compatible with Inconel 690 electrodes should not be processed in this system without design modifications.

g. Identify acceptable processable glass property range (i.e., viscosity, liquidus temperature, electrical conductivity versus temperature, precipitates)

The processable property ranges are listed below: 


\begin{tabular}{|c|c|c|}
\hline Parameter & Acceptance Criteria & Reference 6 Glass \\
\hline Viscosity at $1100^{\circ} \mathrm{C}$ & $20 \leq \mu \leq 100$ poise & 50 poise \\
\hline Liquidus Temperature & $\leq 1050^{\circ} \mathrm{C}$ & $1000^{\circ} \mathrm{C}$ \\
\hline $\begin{array}{c}\text { Glass Electrical } \\
\text { Resistivity at } 1100^{\circ} \mathrm{C}\end{array}$ & $\geq 5 \Omega-\mathrm{cm}$ & $\sim 10 \Omega-\mathrm{cm}$ \\
\hline $\begin{array}{c}\text { Glass Transition } \\
\text { Temperature }\end{array}$ & $2400^{\circ} \mathrm{C}$ & $450^{\circ} \mathrm{C}$ \\
\hline
\end{tabular}

\section{B. Pouring .}

i. Specify average pour frequency and pour rate

WVDP canisters are filled by pouring $13-18$ individual castings. On average, these pour cycles last 30 to 60 minutes and occur at a frequency of 4 to 6 hours.

ii. Identify any pouring problems

During cold verification testing preceding the radioactive campaign, excessive air in leakage into the discharge chamber produced glass fibers at low glass flow rates. Minimizing the pressure difference between the cell and the discharge chamber resolved this issue.

iii. Identify/recommend any solutions/design or any other changes

No changes required.

\section{Noble Metals}

i. Specify noble metals in the feed

Nominal concentrations of noble metal oxides in the glass are PdO 0.03 wt\%, $\mathrm{RhO}_{2} 0.02$ wt\%, and $\mathrm{RuO}_{2} 0.08 \mathrm{wt} \%$.

ii. Identify any settling/electrode-shorting problem

Analysis of the change in resistance in the melter and resistivity data from INE (Germany) indicates that approximately $5 \%$ of the noble metals are retained in the melter. Electrode circuit resistance after nearly 3 years of 
operation are approximately $20 \%$ of the original values and no "shorting" has been observed. The power supply system and electrode cooling system designs have been successful in accommodating these accumulations. The melter life is not expected to be limited by the noble metals.

iii. Identify/recommend any solutions/design or any other changes

No changes required to accommodate the levels of noble metals found in the WVDP waste.

\section{Redox}

i. Specify redox of the feed and melter

Sugar is added to slurry feed for the melter for redox control as described below. Total carbon concentrations in the feed slurry have ranged from 18,000 to $35,000 \mathrm{ppm}$. No measurable ferrous iron has been detected and none is expected in the HLW glass product.

ii. Identify redox measurement and control

A relationship between nitrate, total solids, and carbon concentration in the melter feed is used to determine how much sugar to add to each feed batch. This relationship was developed from mini-melter testing and was verified at full-scale. The feed makeup target relationship is:

iii. Identify redox measurement and control

No foaming or metallic phase precipitation events have been observed.

iv. Identify/recommend any solutions/design or any other changes

This system for redox control has worked well, no changes are necessary for the PUREX waste stream and melter.

\section{E. Technical Maturity}

i. Availability of the melter system on a production scale.

Availability of the melter system [defined by time that slurry was pumped to the melter divided by total time] was $71 \%$. This includes durations not directly attributable to the Vitrification Facility, e.g. Waste Tank Farm maintenance and equipment upgrades. 
ii. Demonstrated scale of operation - Identify largest scale of operation ( $\mathrm{kg}$ glass $/ \mathrm{hr}$ ).

This is a HLW production glass melting system. Maximum demonstrated glass production rate is $55 \mathrm{~kg} / \mathrm{hr}$, and an average of $35 \mathrm{~kg} / \mathrm{hr}$.

\section{F. Facility/System Integration}

i. Feed preparation requirements - Identify limitations on feed characteristics (e.g. acid feed, maximum solids, etc.)

The feed to the melter is maintained within a $\mathrm{pH}$ range of 2 to 4 , at a total solids up to $63 \mathrm{wt} \%$, and with nominal particle sizes of $<100 \mu \mathrm{m}$. The particle size restriction is related to the slurry sampling and chemical analysis requirements.

ii. Off-gas system requirements - Identify flow rate and complexity of off-gas treatment system required

Nominal off-gas system flow for the vitrification system is $700 \mathrm{scfm}$. The melter off-gas system is arranged as follows:

film cooler and pressure control injection air submerged bed scrubber roughing mist eliminator heater parallel high efficiency mist eliminator/dual HEPA units parallel re-heater parallel dual HEPA three parallel blowers, 2 electric; 1 diesel parallel re-heater parallel $\mathrm{NO}_{\mathrm{x}}$ abatement selective catalytic reduction units stack

iii. Number of melter trains and demands placed on plant systems - Identify any special or unusual requirements (i.e., special canister handling or melter cell heat load requirements).

A single melter train is installed at the WVDP.

iv. Plant service requirements - Identify steam, water, air, energy, etc. required to operate the melter system.

The melter requires cooling water, instrument air, utility air, electrical power and instrumentation, and ventilation as outlined below: 


$\begin{array}{ll}\text { cooling water: } & \text { exterior cooling jacket } \\ \text { instrument air: } & \begin{array}{l}\text { level detection dip tube } \\ \text { airlift system }\end{array} \\ \text { utility air: } & \begin{array}{l}\text { electrode cooling } \\ \text { dam cooling } \\ \text { pouring trough cooling }\end{array} \\ \text { electrical power: } & \begin{array}{l}\text { start up heaters } \\ \text { electrode circuits } \\ \text { discharge heaters }\end{array} \\ \text { instrumentation: } & \text { thermocouples } \\ \text { ventilation: } & \text { off-gas effluents }\end{array}$

v. Plant service requirements - Identify steam, water, air, energy, etc. required to operate the melter system.

The melter is roughly 11.5 feet long $x 11$ feet high $\times 10.5$ feet wide, not including the electrode extensions for penetration of the cell walls, and weighs 52 tons. It is designed to be rolled in place for replacement at the WVDP.

The melter is designed for remote replacement of the consumable components (thermocouples, thermowells, dip tube, auxiliary heaters) and a complete installed spare glass discharge.

vi. Ability to operate in a remote environment - Identify.

The melter has been operated remotely for approximately 3 years.

vii. Identify ability to fill / handle $2^{\prime}$ diameter $\times 10^{\prime}$ tall canisters

Through April 1999, 23810 foot tall x 2 foot diameter canisters have been filled with high-level waste glass at an average fill height of $90.4 \%$

\section{G. Operability}

i. Ease of Control - Describe required controls

The melter control systems are described below: 
Power - Three single phase, phase angle fired SCR electrode circuits with an average glass temperature input. The side-to-side electrode circuit is directly controlled with the two side-to-both circuits slaved with an independent, variable constant fraction of the side-to-side circuit as their set point.

Three discharge heater circuits with phase angle fired SCR's. All three circuits are tied to a single controller and are adjusted as a unit.

Glass Pour - $\quad$ Manual air injection with video showing glass stream to operators.

Pressure - $\quad$ Air injection after fill cooler to maintain plenum above molten glass at $\sim 0.5 \mathrm{inch}$ water column less than the cell pressure.

ii. Remotability - Must be adaptable to a remote, radioactive environment.

Melter is currently in a remote, production installation.

iii. Reliability - Identify on-line efficiency and demonstrated maximum.

Overall efficiency [defined by the time the melter is fed divided by total time] of $71 \%$. Melter system was able to run at $>95 \%$ efficiency for several month durations.

iv. Maintainability - Describe normal maintenance requirements.

Normal maintenance requirements:

Glass thermocouples - 3 months

Glass thermowells - 6 months

Glass level dip tube -6 months

Discharge heaters - 1 to 2 years

vi. Estimated lifetime - Identify (also provide supporting electrode/refractory corrosion data) 
Two versions of this melter have been operated. The first, for the FACTS campaign, operated from December 1984 through November 1989 and produced approximately 100 canisters over that period. Continued melter operation would have been possible at that time, but the FACTS program ended. Approximately $160,000 \mathrm{~kg}$ of glass were produced in the FACTS melter resulting in less than $1 \mathrm{~cm}$ of glass contact refractory loss and up to $5 \mathrm{~cm}$ of spall from the castable lid refractory.

The second melter began operation in September 1995 and operation is anticipated through September 2002.

\section{H. Features Creating Special or Unusual Safety or Environmental Problems}

i. Plant/Worker Safety.

The melter system has been in radioactive operation since June 1996 following a formal DOE Operational Readiness Review process.

ii. Identify environmental remediation requirements for special or significant waste streams

The process off-gas is the only significant continuous secondary waste stream and contains radionuclides and nitrogen oxides. The particulate component of the off-gas is returned from the wet scrubber to the melter feed preparation cycle. The off-gas system, described above, exceeds the radioactivity removal and $\mathrm{NO}_{\mathrm{x}}$ destruction requirements for the site.

iii. Off-gas - extent of system required to remediate off-gas so it can meet site release rates and Clean Air Act requirements for $\mathrm{NO}_{x}$, radionuclides, etc.

The off-gas system components were described in F.ii. above.

iv. Generation of secondary waste streams.

Identify mass and volume of waste per time (including melter change-outs above) as well as compositions. Identify potential methods of secondary waste disposal and effect on process flowsheet

The routinely replaced melter components are described in G.iv. above. The approximate volume and weight of these components are listed below: 


\begin{tabular}{|c|c|c|}
\hline Item & Envelope Volume & Weight \\
\hline Glass Thermocouples & $<1 \mathrm{ft}_{\cdot 3}$ & $10 \mathrm{lbs}$. \\
\hline Glass Thermowells & $<10 \mathrm{ft}_{3}$ & $80 \mathrm{lbs}$. \\
\hline Glass Dip Tube & $<10 \mathrm{ft}_{3}$ & $150 \mathrm{lbs}$. \\
\hline $\begin{array}{c}\text { Discharge Heater } \\
\text { Assembly }\end{array}$ & $<50 \mathrm{ft}_{3}$ & $2000 \mathrm{lbs}$. \\
\hline
\end{tabular}




\section{Appendix D}

Meeting Handouts 



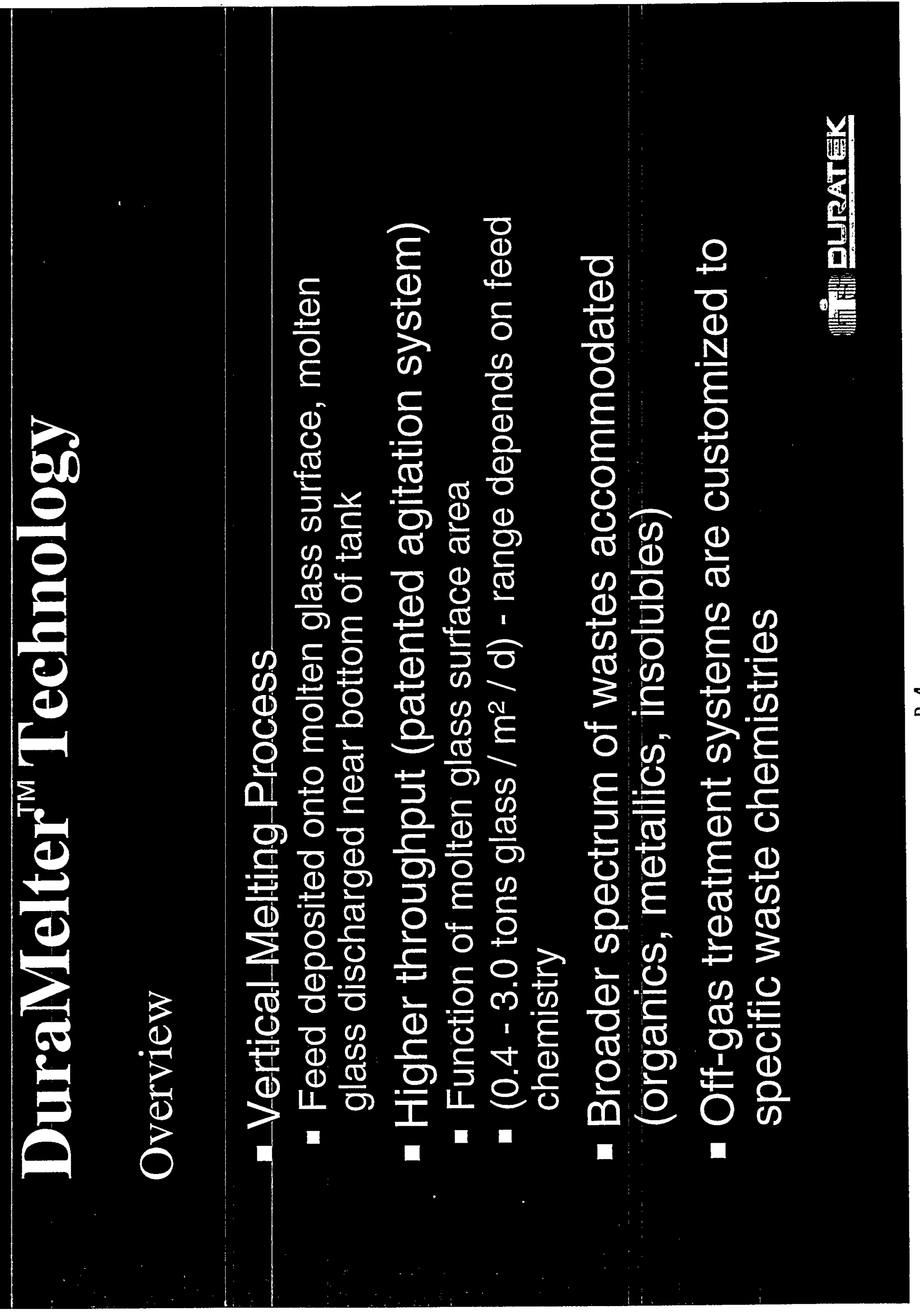



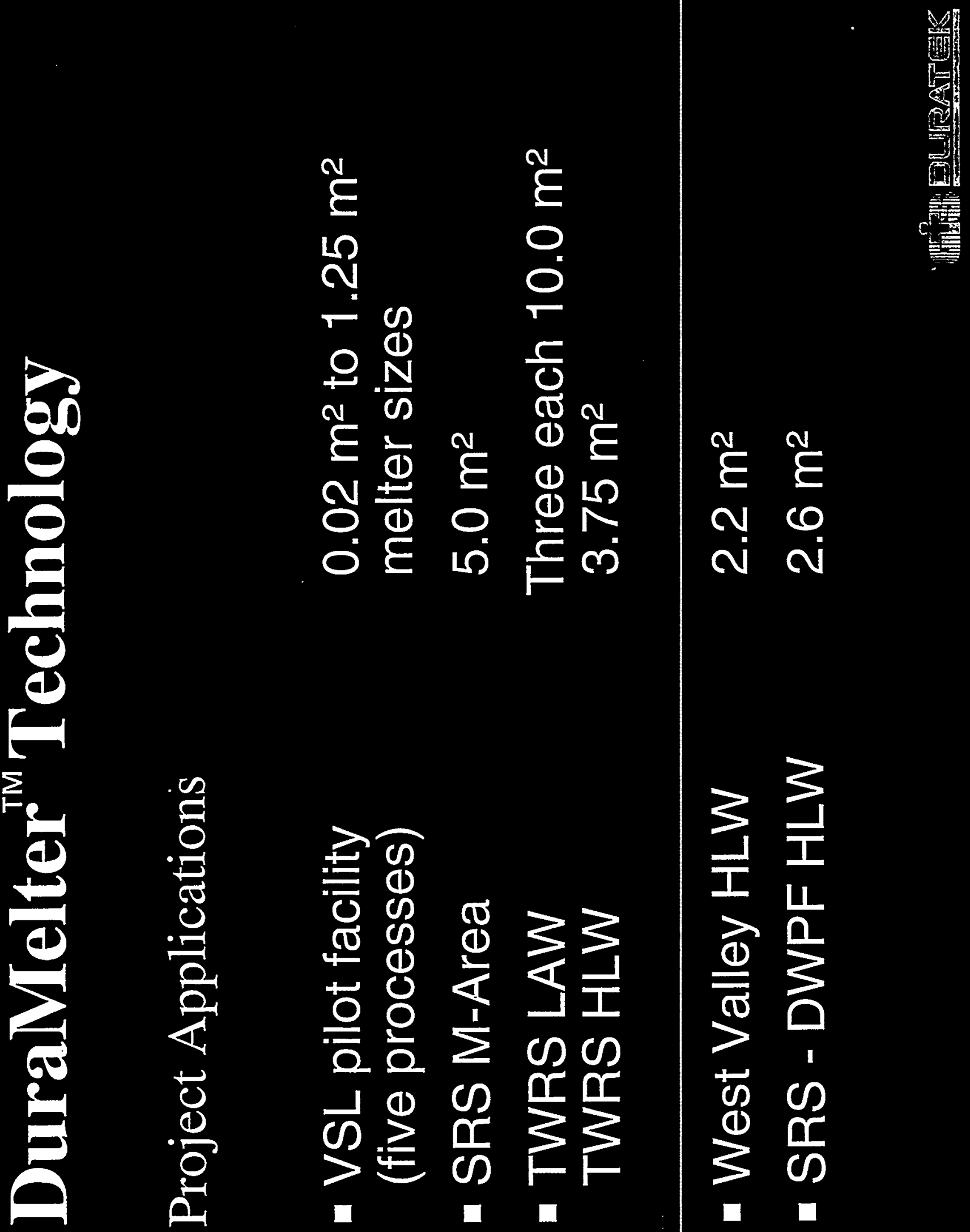


\section{M-Area}

\section{Plant Performance}

\begin{tabular}{|c|c|c|}
\hline & Design Bas is & Actual \\
\hline Specific Feed Rate (GPH) & 180 & $184:\left(177_{11}\right)$ \\
\hline Specific Glass Production (TPD) & 5 & $4.25 *(3.14 \cdots)$ \\
\hline Process Availability (\%) & 80 & $87.3 *(77.5 \ldots)$ \\
\hline Average Feed Rate (GPH) & 144 & $160 *(137 \ldots)$ \\
\hline Average Glass Production (TPD) & 4 & $3.71:(2.43 \ldots 1)$ \\
\hline Total Feed Volume (2) (gallons) & 925,000 & $1,235,650$ \\
\hline Total Product Volume (gallons) & 156,200 & 199,368 \\
\hline Total Glass Mass (lbs.) & $2,125,000$ & $2,175,389$ \\
\hline Waste Volume Reduction (\%) & $77^{-}$ & 71 \\
\hline Process Campaign Duration (days) & 270 & 820 \\
\hline
\end{tabular}

* May 1 - August 31, 1998

(1) Since Dec. 97 Restart

(2) Includes chem. add dilution, recycle, clean closure, rinsente

(3) Includes melter replacement outage 

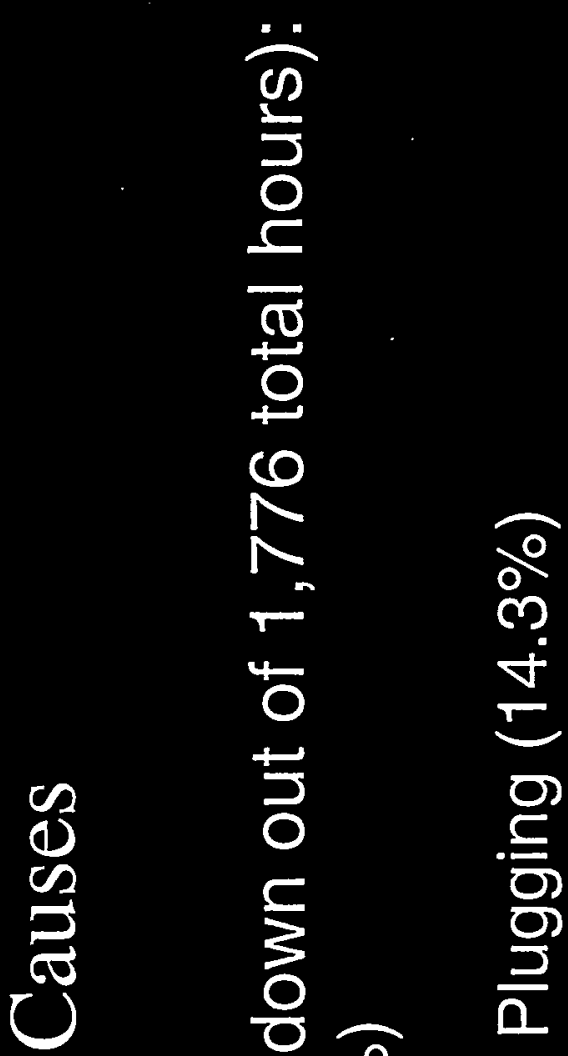

c

N

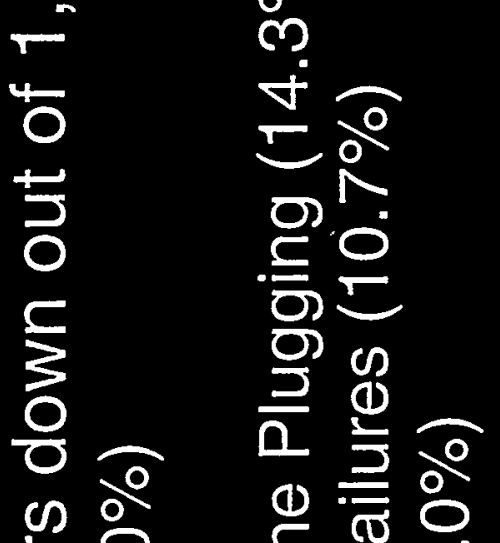

\&

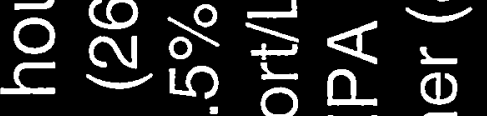

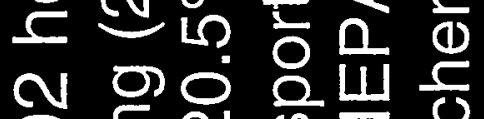

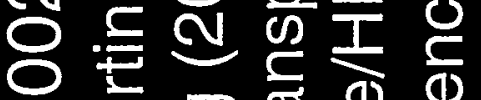

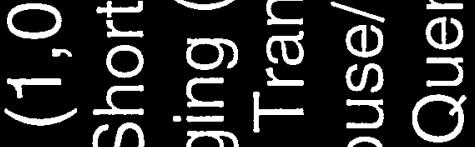

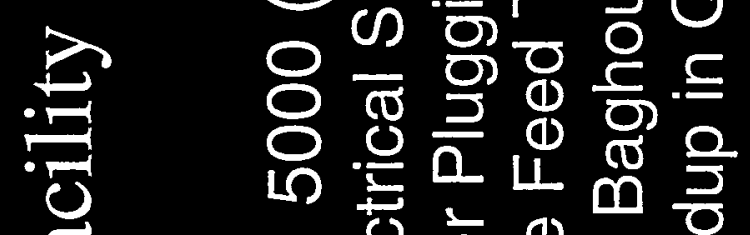

8

(6)

I

$\rightleftarrows$

递

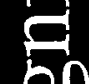

60

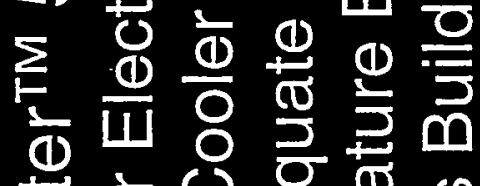

Ф

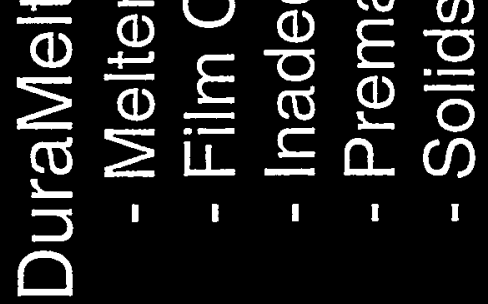

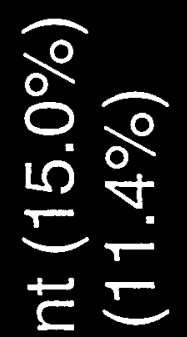

㯿

क्ष

10

Чo $\overbrace{\infty}^{\circ}$

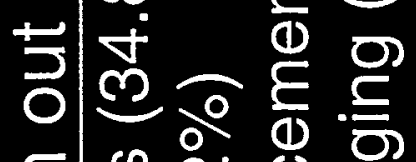

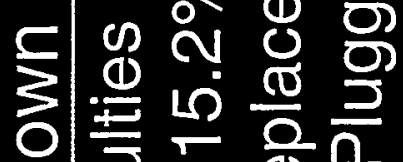

楼

की क⿺辶

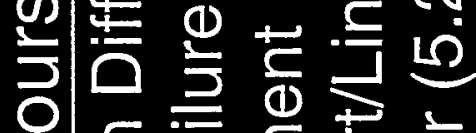

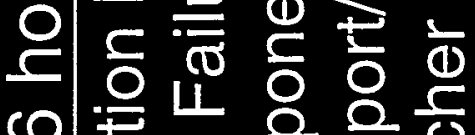

웜은 을 응 엉

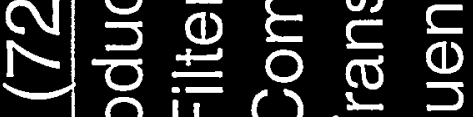

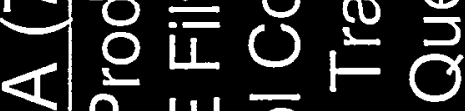

음늘 형.

잉ㅎㅀ

可

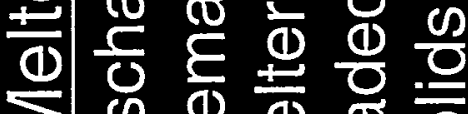

$\sum$ 에

ธิธ 


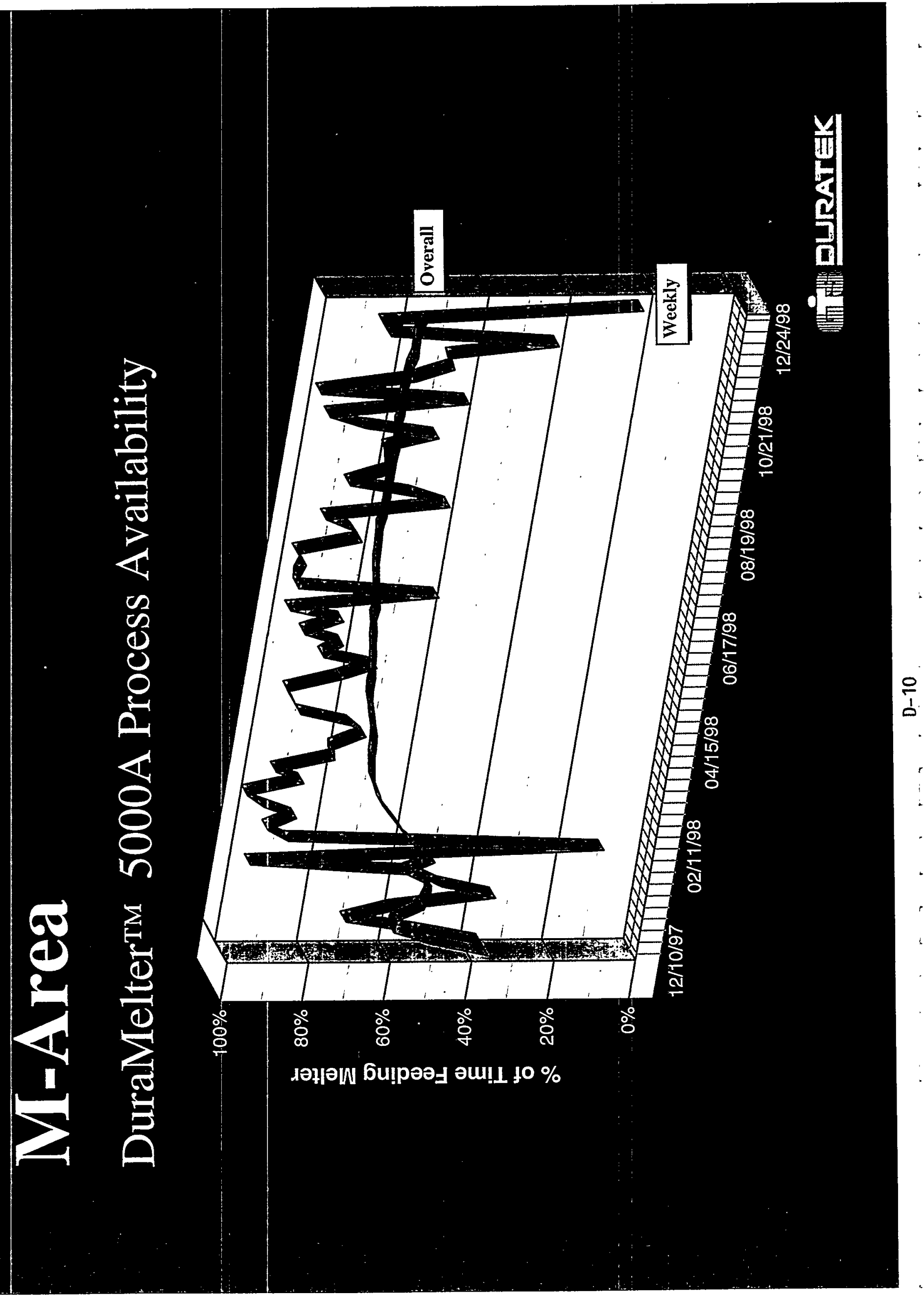




\section{M-Area}

DuraMelter ${ }^{\mathrm{TM}}$ 5000A Glass Production

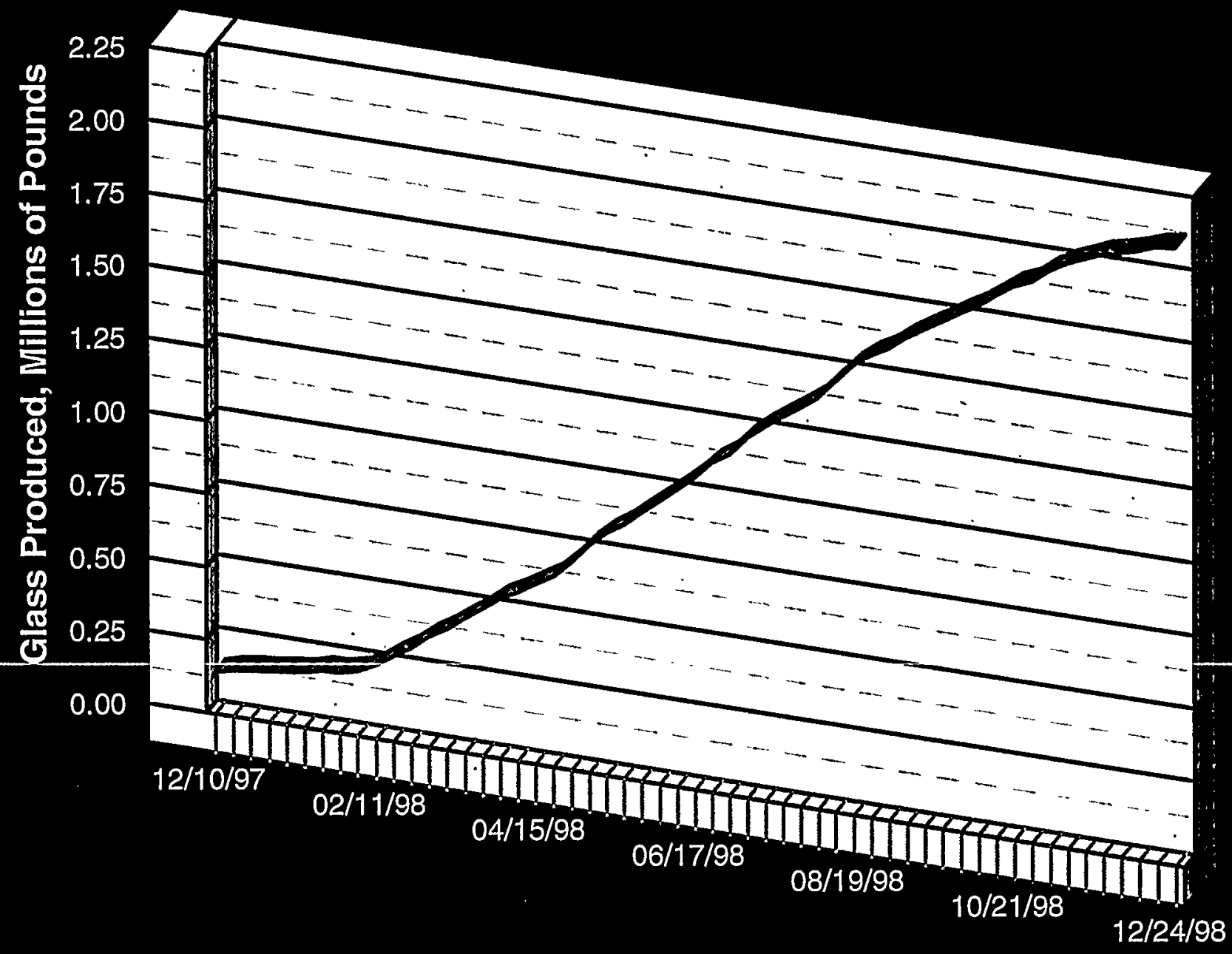

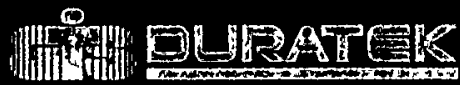




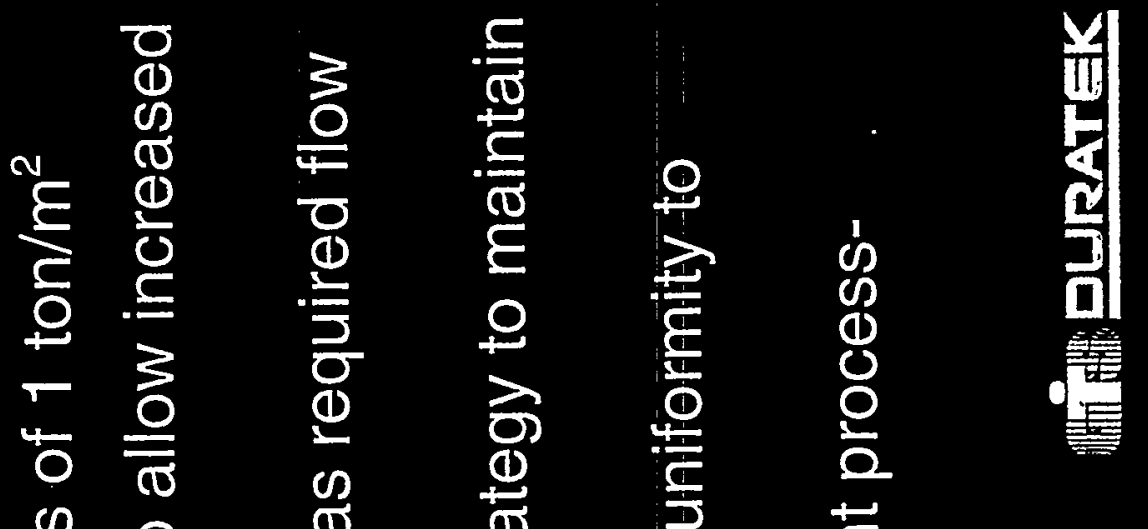

$\phi$ o 0 to $5+$

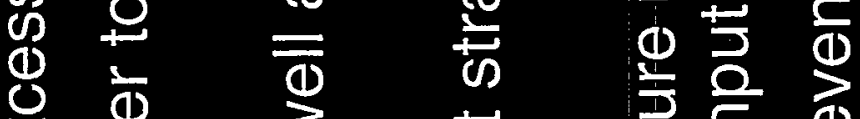

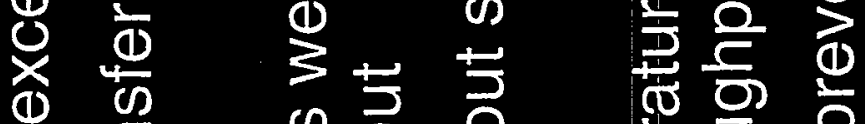

(1) 응

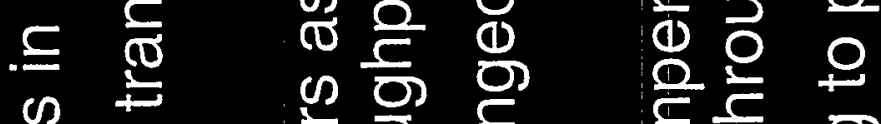

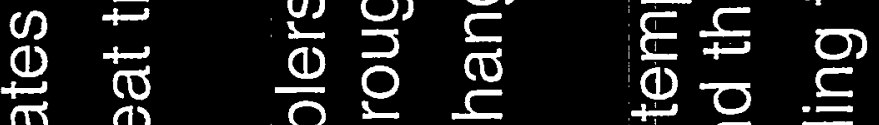

은 응 을

등 응 은 $\frac{\mathrm{g}}{\mathrm{N}}$

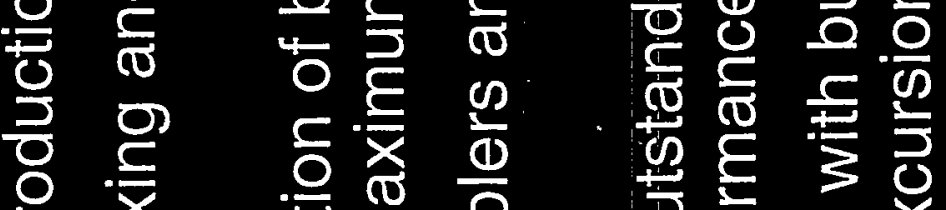

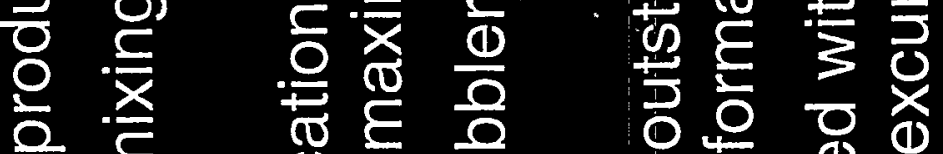

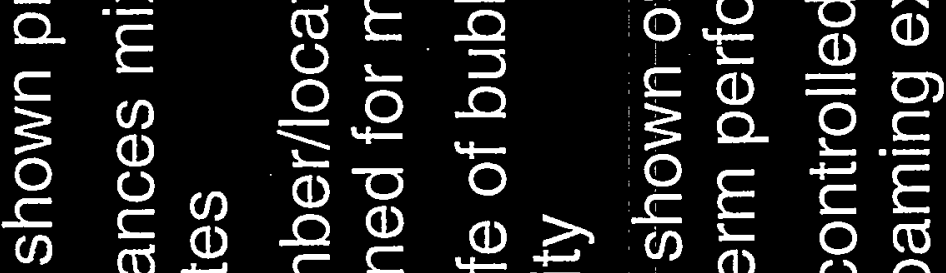

क Ф

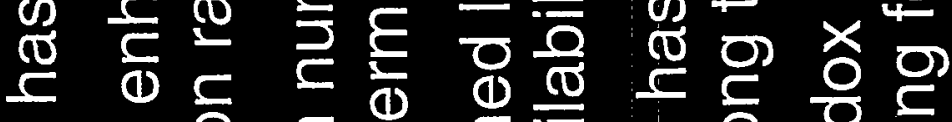

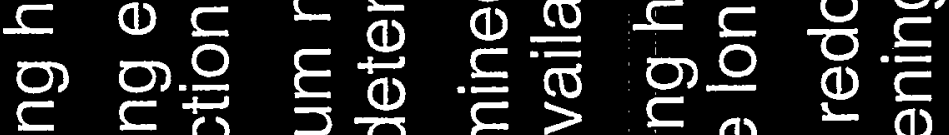

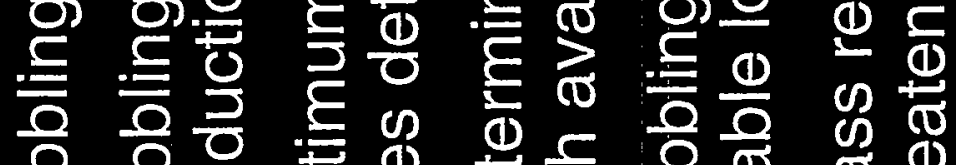

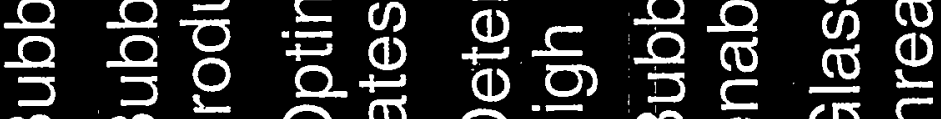

๓ 


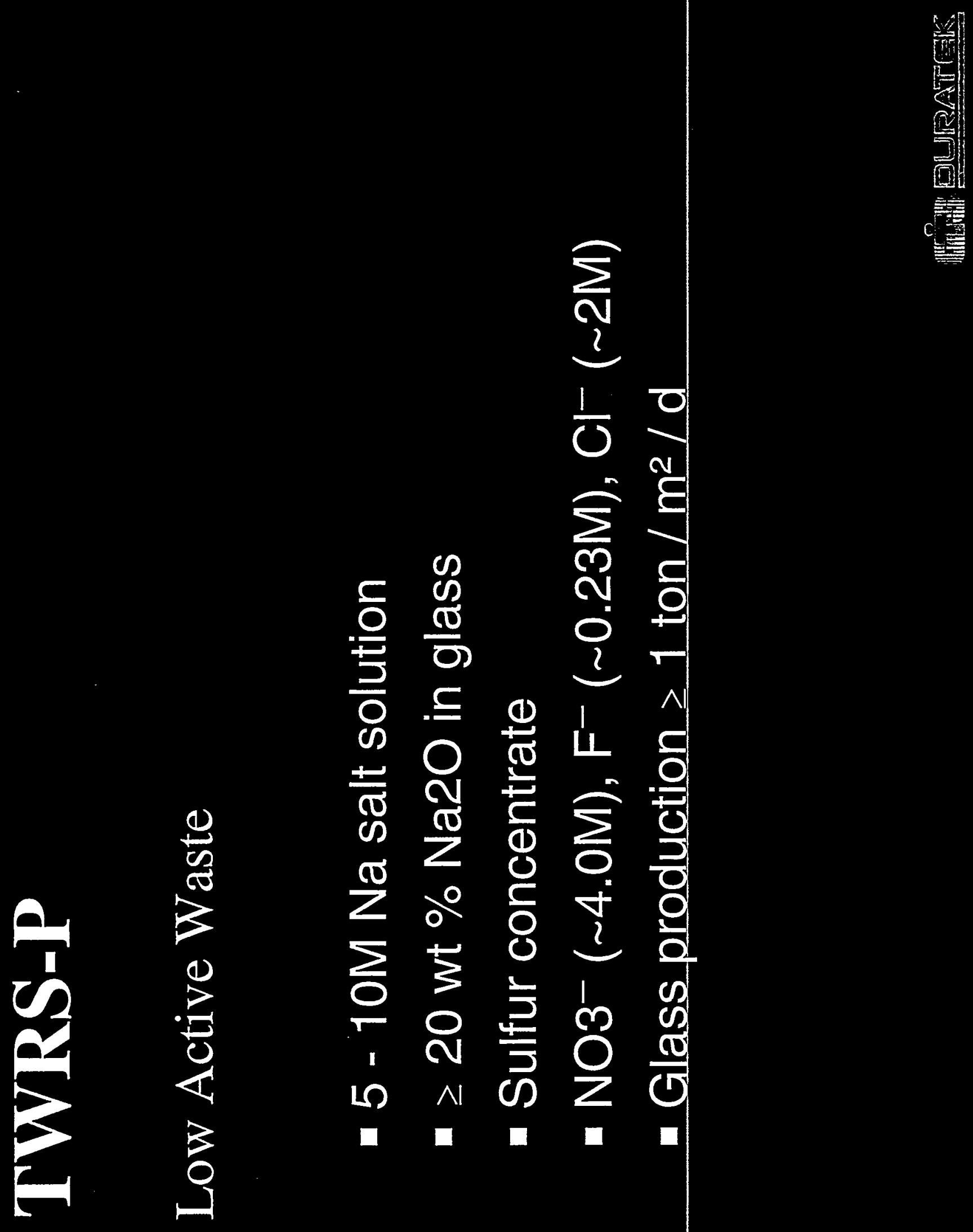


\title{
RADON EXPERIENCE IN HIGH LEVEL AND ACTINIDE- CONTAINING WASTES VITRIFICATION
}

\author{
presented by \\ S.V. STEFANOVSKY
}

SIA Radon

SIA Radon is responsible for management of low- and intermediate-level radioactive waste (LILRW) of central Russia, including

- collection,

- transportation,

- interim storage,

- treatment

- final disposal

and moreover

- radioecological monitoring

- remediation of radiation accidents

- environmental clean-up and restoration

Radon in cooperation with Minatom carries out works on treatment of simulated high level waste. 
Hystorically. the most attention was paid to wastes formed within the nuclear fuel cycle (NFC), especially to high level liquid waste of spent fuel reprocessing.

Low- and intermediate level wastes take significantily larger voiume.

Great volumes of low and intermediate level liquid wastes (LILLW) not connected to the nuclear fuel cycle are also formed.

Extreme situation exists at Nuclear Power Plants, where reactors VVER-1000 and RBMK- 1000 produce yearly $220-300 \mathrm{~m}^{3}$ and $1000-1200 \mathrm{~m}^{3}$ of wastes, respectively.

\section{SAFE DISPOSAL OF LILLW IS EXTREMELY VITAL QUESTION.}

SIA "Radon" deals with collection, transportation, interim storage, treatment, and final disposal of radioactive wastes other than NFC.

Moreover, Radon in cooperation with "Rosenergoatom" deals with NPP waste problem, including treatment and final disposal.

At the present time the most of liquid NPP wastes are stored in stainless steel tanks.

Possible methods of NPP waste treatment are

- cementation,

- bituminization,

- ceramization,

- vitrification. 
Vitrification process from economic point of view are comparable with other methods considered, and taking into account transportation and long-term storage of conditioned wastes, the vitrification process becomes much more preferable.

Research works on NPP waste vitrification were started since the middle of 1980s.

THE MAIN GOAL OF OUR WORK:

\section{DEVELOPMENT AND TESTING OF GLASSES AND CERAMICS SUITABLE FOR NPP WASTE IMMOBILIZATION AND TECHNOLOGIES TO PRODUCE THEM}

This presentation summarizes Radon activity in NPP waste vitrification.

\section{MILESTONES}

- Development and lab-scale testing of waste glasses

- Selection of appropriate technologies

- Design and construction of bench-scale units

- Bench-scale testing

- Testing of waste forms under natural conditions

- Selection of of the most suitable waste forms

- Design and construction of pilot plant

- Start-up and preliminary testing

- Put into operation 
FEATURE OF THE TECHNOLOGY CHOSEN IS SEMI-LIQUID

(SLURRY) FEEDING (WATER CONTENT 20-25 WT.\%).

THIS TECHNOLOGY HAS SIGNIFICANT ADVANTAGES

OVER BOTH WET SLURRY AND DRY FEEDINGS:

- HIGHER PRODUCTIVITY DUE TO ACCELERATION OF SILICATE FORMATION IF MINOR WATER IS PRESENT;

- NO DUSTING OR DROPLETS CARRY-OVER;

- EASIER TRANSPORTATION IN PIPES TO BE FED INTO A MELTER;

- NO LEAKAGE THROUGH GAPS AS COMPARED TO

SLURRY OR SOLUTION FEEDING. 


\section{ANALYTICAL METHODS:}

- atomic absorption spectroscopy,

- emission spectral analysis,

- $\beta$ - $\gamma$-spectrometry,

- $\alpha$-spectrometry,

- infra-red spectroscopy,

- electron paramagnetic resonance,

- X-ray diffraction,

- scanning and transmission electron microscopy,

- electron microprobe analysis,

- viscosimetry,

- electric resistivity measurements,

- ${ }^{60} \mathrm{Co}$ source for radiation research.

\section{TECHNOLOGICAL RESEARCH:}

- development and testing of the cold crucible inductive melting process,

- the cold crucible design,

- development and testing of the plasma arc treatment of solid waste,

- development and testing of the plasma arc melting process,

- development of the integrated plasma treatment-inductive melting process. 
- resistive furnace for lab-scale investigations (up to $\sim 1 \mathrm{~kg}$ of batch),

- bench-scale facility (1-10 $\mathrm{kg}$ of batch) based on the cold crucible (up to 10$20 \mathrm{~kg} / \mathrm{h}$ ),

- industrial-scale facility (10-50 kg of batch) based on the cold crucible (up to $30 \mathrm{~kg} / \mathrm{h}$ ),

- bench-scale facility for plasma torch melting (up to $10-20 \mathrm{~kg} / \mathrm{h}$ ),

- industrial-scale vitrification plant (up to $75 \mathrm{~kg} / \mathrm{h}$ ) for production of glass blocks each of $\sim 25-30 \mathrm{~kg}$.

\section{DEVELOPMENT AND TESTING OF GLASS AND GLASS- LIKE MATERIALS FOR LOW AND INTERMEDIATE LEVEL RADIOACTIVE WASTE IMMOBILIZATION}

\section{Institutional LILRW}

Major component: sodium nitrate as (up to $\sim 600 \mathrm{~kg} / \mathrm{m}^{3}$ ).

Minor components: calcium-magnesium carbonate, ferrous compounds, sulfates and chlorides.

\section{Glasses}

- Borosilicate

- Boron free aluminosilicate glasses may be used. 


\section{A STUDY OF MATERIALS FOR WASTE IMMOBILIZATION}

\section{MATERIALS:}

- GLASS, INCLUDING PHASE SEPARATED GLASS,

- GLASS-CRYSTALLINE MATERIALS,

- glass COMPOSITE MATERIALS,

- SINGLE PHASE CERAMICS (ZIRCONOLITE/PYROCHLORE, MURATAITE, PEROVSKITE, NZP, APATITE, SPHENE),

- POLYPHASE CERAMICS (SYNROC)

\section{GLASS:}

- development and testing of glasses for LLLRW immobilization,

- chemical analysis and determination of glass properties (viscosity, electric resistivity, density, leaching, radiation stability, etc.),

- study of glass structure,

\section{INHOMOGENEOUS and CERAMIC MATERIALS:}

- study of phase separated glasses, glass crystalline materials, composite, and ceramic materials,

- phase analysis,

- elements distribution among co-existing phases,

- determination of material properties (density, leaching, mechanical strength, radiation stability, etc.). 
Natural minerals and rocks:

- datolite $\mathrm{CaBSiO}_{4}(\mathrm{OH})$,

- dolomite $\mathrm{CaMg}\left(\mathrm{CO}_{3}\right)_{2}$,

- bentonite,

- loam clay.

Glass forming systems:

1. $\mathrm{Na}_{2} \mathrm{O}-\mathrm{CaO}-(\mathrm{MgO})-\mathrm{Al}_{2} \mathrm{O}_{3}-\mathrm{SiO}_{2}$;

2. $\mathrm{Na} 2 \mathrm{O}-\mathrm{CaO}-(\mathrm{MgO})-\mathrm{Al}_{2} \mathrm{O}_{3}-\mathrm{Fe}_{2} \mathrm{O}_{3}-\mathrm{SiO}_{2}$;

3. $\mathrm{Na} 2 \mathrm{O}-\mathrm{CaO}-(\mathrm{MgO})-\mathrm{Al}_{2} \mathrm{O}_{3}-\mathrm{B}_{2} \mathrm{O}_{3}-\mathrm{SiO}_{2}$;

4. $\mathrm{Na}_{2} \mathrm{O}-\mathrm{CaO}-(\mathrm{MgO})-\mathrm{Al}_{2} \mathrm{O}_{3}-\mathrm{Fe}_{2} \mathrm{O}_{3}-\mathrm{B}_{2} \mathrm{O}_{3}-\mathrm{SiO}_{2}$.

Radioactive constituent: ${ }^{134,137} \mathrm{Cs},{ }^{90} \mathrm{Sr},{ }^{60} \mathrm{Co},{ }^{144} \mathrm{Ce}$.

Waste volume activity: $10^{7}-10^{10} \mathrm{~Bq} / \mathrm{m}^{3}$ ( $\beta$ - $\gamma$-emitters) and $10^{5}-10^{6} \mathrm{~Bq} / \mathrm{m}^{3}(\alpha-$ emitters).

Glass specific activity: $10^{5}-10^{7} \mathrm{~Bq} / \mathrm{kg}$ ( $\beta$ - $\gamma$-emitters) and $10^{2}-10^{4}$ ( $\alpha$-emitters).

It corresponds to weight concentration of $10^{-2}-10^{-5} \%$.

The same systems are basic for conventional glasses used in industry and glass formation in these systems is studied well. A feature of waste glasses is elevated sodium content in order to reach the highest waste oxide content. 
Glass forming systems studied

- Waste oxides - $2 \mathrm{CaO} \mathrm{B}_{2} \mathrm{O}_{3}-\mathrm{SiO}_{2}$

- Waste oxides - $\mathrm{CaO} \mathrm{B}_{2} \mathrm{O}_{3}-\mathrm{SiO}_{2}$

- Waste oxides $-\mathrm{Al}_{2} \mathrm{O}_{3}-\mathrm{SiO}_{2}$

- $\mathrm{NaKO}$ - (Ca, $\mathrm{Mg}) \mathrm{O}-\mathrm{Al}_{2} \mathrm{O}_{3}-\mathrm{SiO}_{2}$

- Waste oxides - $(\mathrm{CaO})-\mathrm{Al}_{2} \mathrm{O}_{3}-\mathrm{TiO}_{2}-\mathrm{SiO}_{2}$

Methods of investigation of glass and glass composite structure

- X-ray diffraction

- Infra-red spectroscopy

- Electron paramagnetic resonance

- Replica and transmission electron microscopy

Glass properties studied

- Leaching of radionuclides studied

- Density

- Compressive strength

- Diffusion of radionuclides

- Volatilization of radionuclides

- Molten glass viscosity

- Molten glass resistivity

Batch Compositions (wt.\%).

\begin{tabular}{|c|c|c|c|c|c|}
\hline No. & Waste & Waste & Datolite & Sandstone & Bentonite \\
\hline 1 & $\begin{array}{c}\text { Moscow } \\
\text { Station }\end{array}$ & $35-50$ & $25-35$ & $10-20$ & $10-15$ \\
\hline 2 & $\begin{array}{c}\text { NPP with } \\
\text { RBMK }\end{array}$ & $30-45$ & $25-40$ & $10-20$ & $10-20$ \\
\hline 3 & $\begin{array}{c}\text { NPP with } \\
\text { VVER }\end{array}$ & $45-60$ & - & $15-30$ & $20-30$ \\
\hline
\end{tabular}




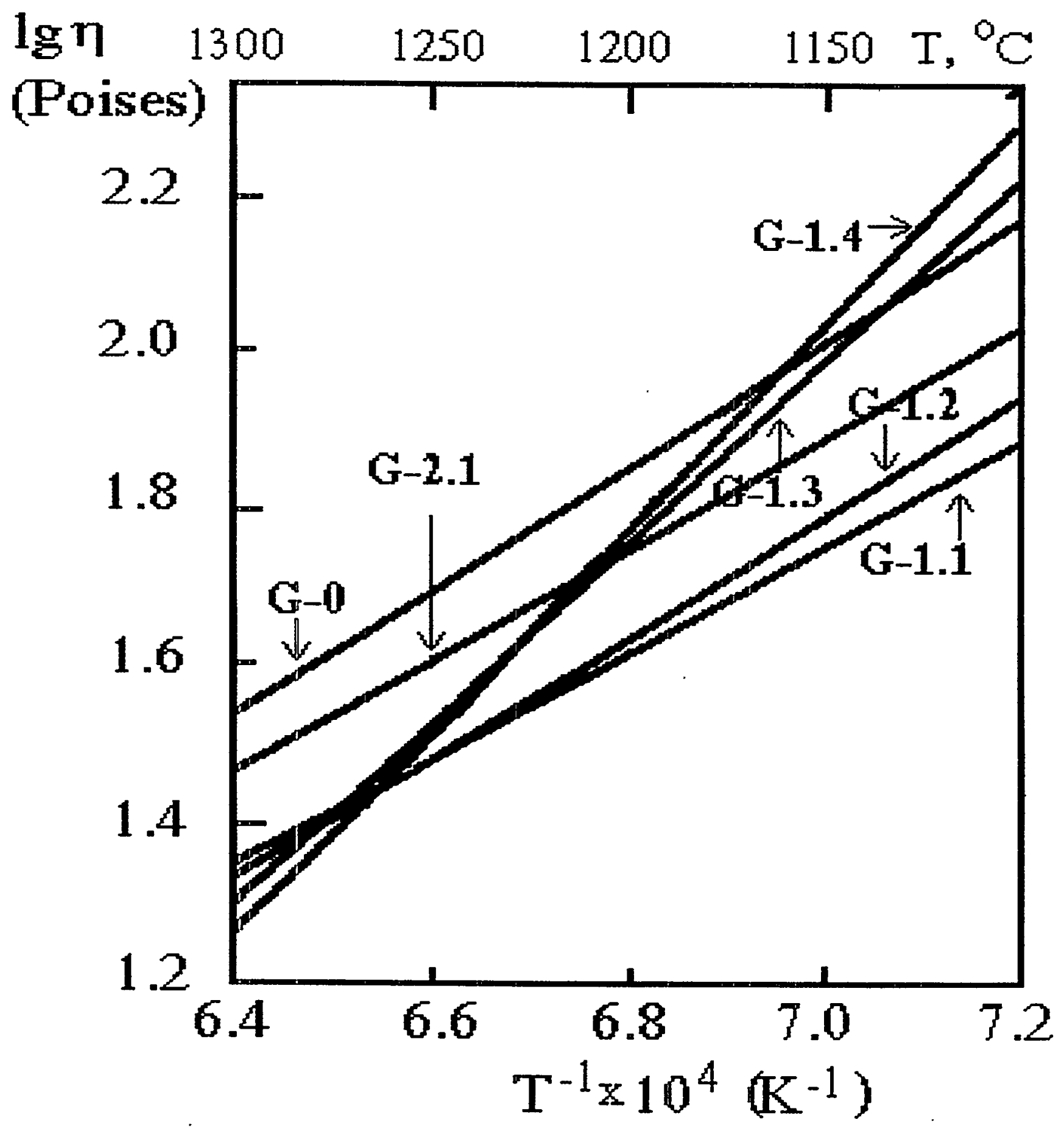

Viscosity $(\eta)$-inverse temperature $\left(T^{-1}\right)$ relations for glasses studied 


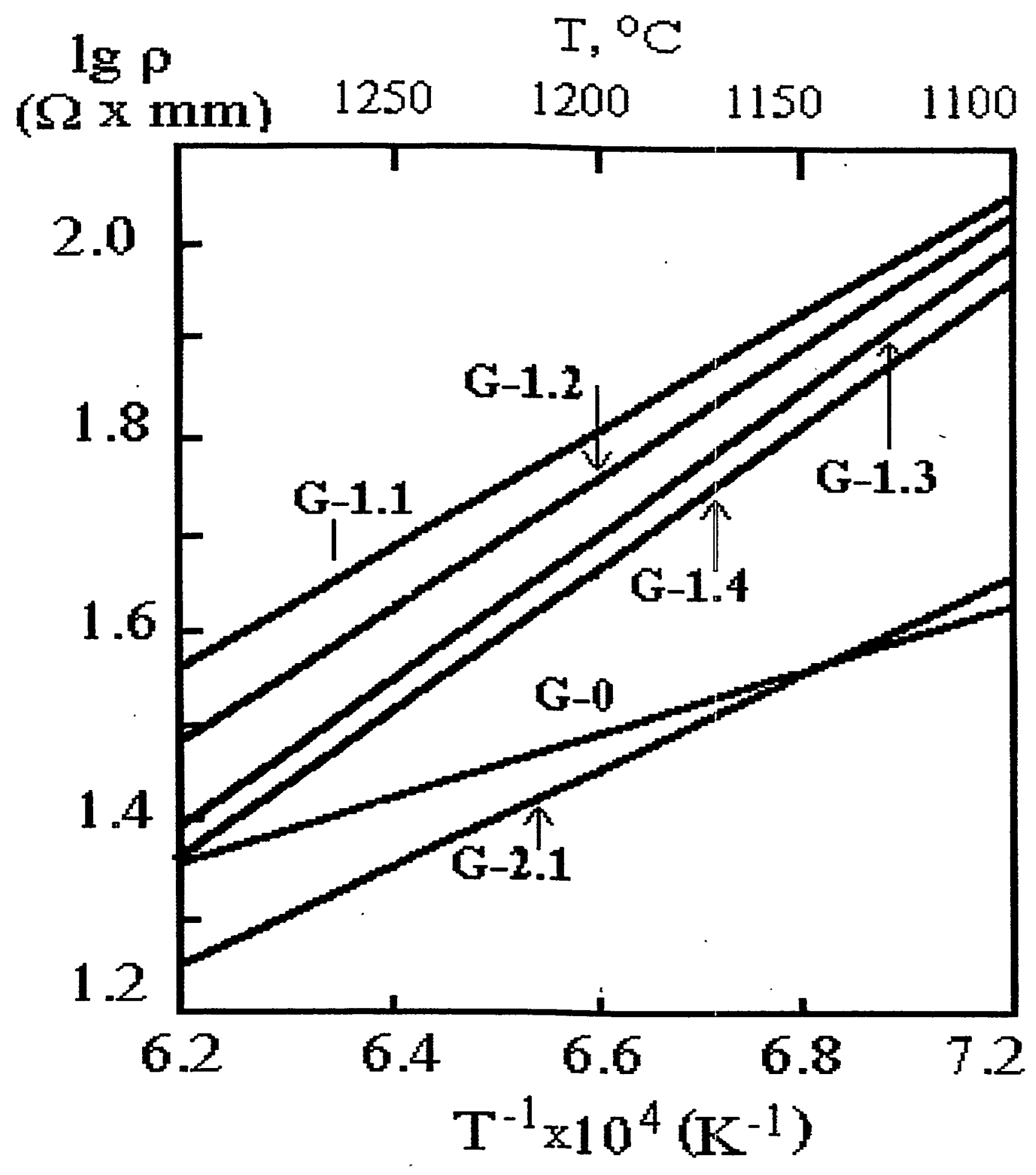

Resistivity ( $\rho$ ) - inverse temperature relations for glasses studied. 
Nuclear Power Plants wastes from RBMK and WWER type reactors. Chemical composition of RBMK waste is very close to institutional waste and it contains mainly sodium nitrate. Therefore, the above-listed systems can be applied for immobilization of RBMK waste as well.

WWER waste contains both sodium nitrate and sodium tetrahydroxylborate as major components. Vitrification of this waste does not require boron containing additives. WWER waste glasses relate to systems \#3 and \#4.

\section{Phase separation problem}

SO42- and $\mathrm{Cl}$ - solubility in silicate melts

Waste oxide content limitation

Excess $\sim 1 \mathrm{wt} \%$

5-10 wt. \%

"yellow phase" formation

\section{Phase separation prevention}

- addition of components increasing sulfate and chloride solubility, such as lead or vanadium oxides;

- vigorous melt agitation followed by fast cooling down to upper annealing temperature to fix dispersed sulfate-chloride phase into the host borosilicate glass;

- addition of reducing agent to feed composition to decompose sulfates and remove their with off-gas. 
Disadvantages of Joule-heated ceramic melter:

- Temperature limitation

- Corrosion of ceramic refractories and electrodes

- Relative low productivity

- Large overall dimensions

- Long time of start-up and lag

Advantages of "cold crucible" melter:

- No refractories and electrodes contacting with melt

- No temperature limitation

- High specific productivity

- Short time of start-up

- Small dimensions

- Long life time

Wasteforms produced in "cold crucible"

- Borosilicate glass (30-40 wt.\% of waste oxides)

- Aluminosilicate glass (20-45 wt.\% of waste oxides)

- Glass composite materials (up to $50 \mathrm{wt} \%$ of waste components including sulfates, molybdates, chlorides, incinerator ash)

- Apatite-based glass ceramics (melted incinerator ash)

- Sphene-based giass ceramics

- SYNROC

\section{Glass forming additives}

- Datolite $\mathrm{CaBSiO}_{4}(\mathrm{OH})$

- Sandstone

- Bentonite or loam clay 


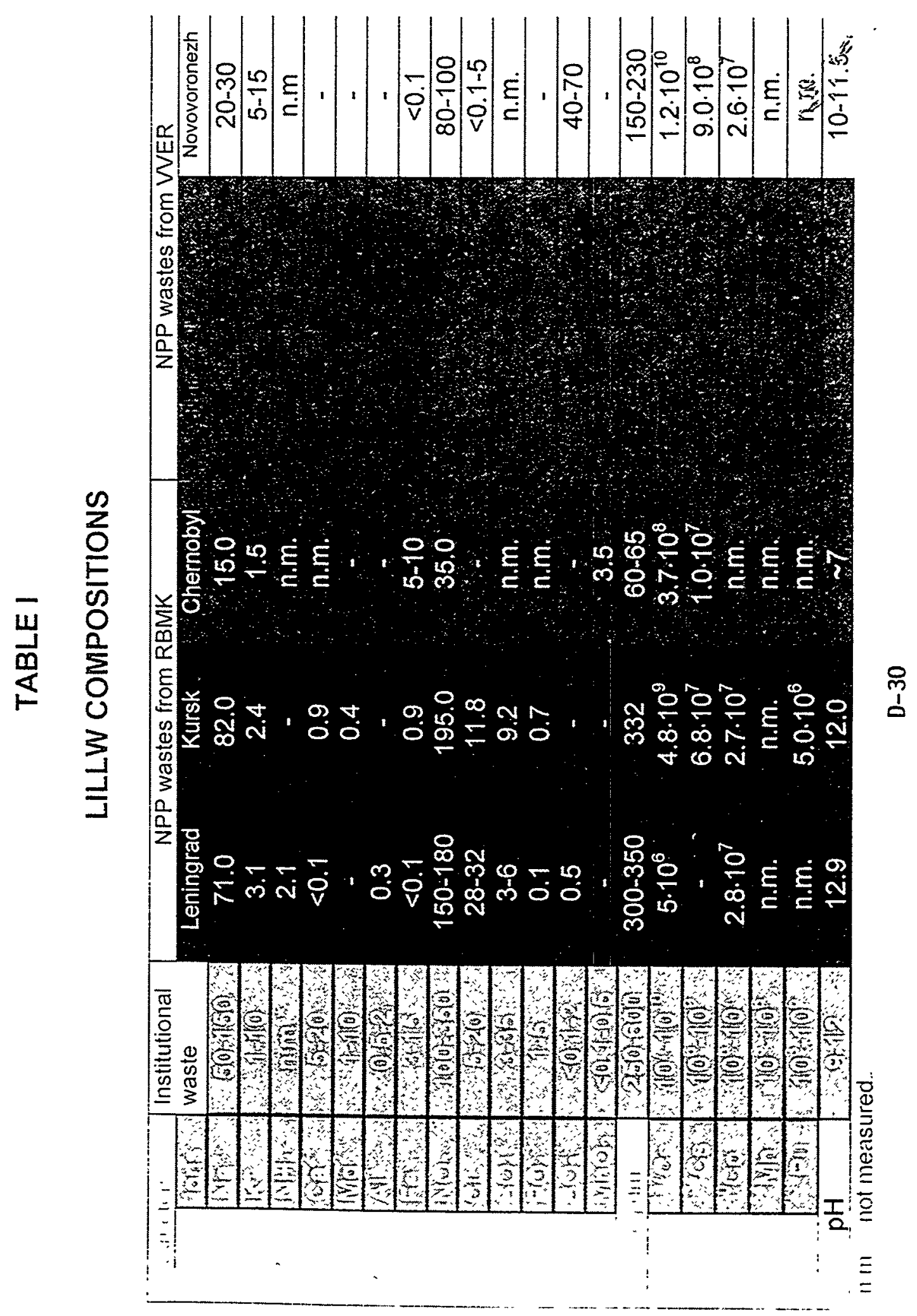




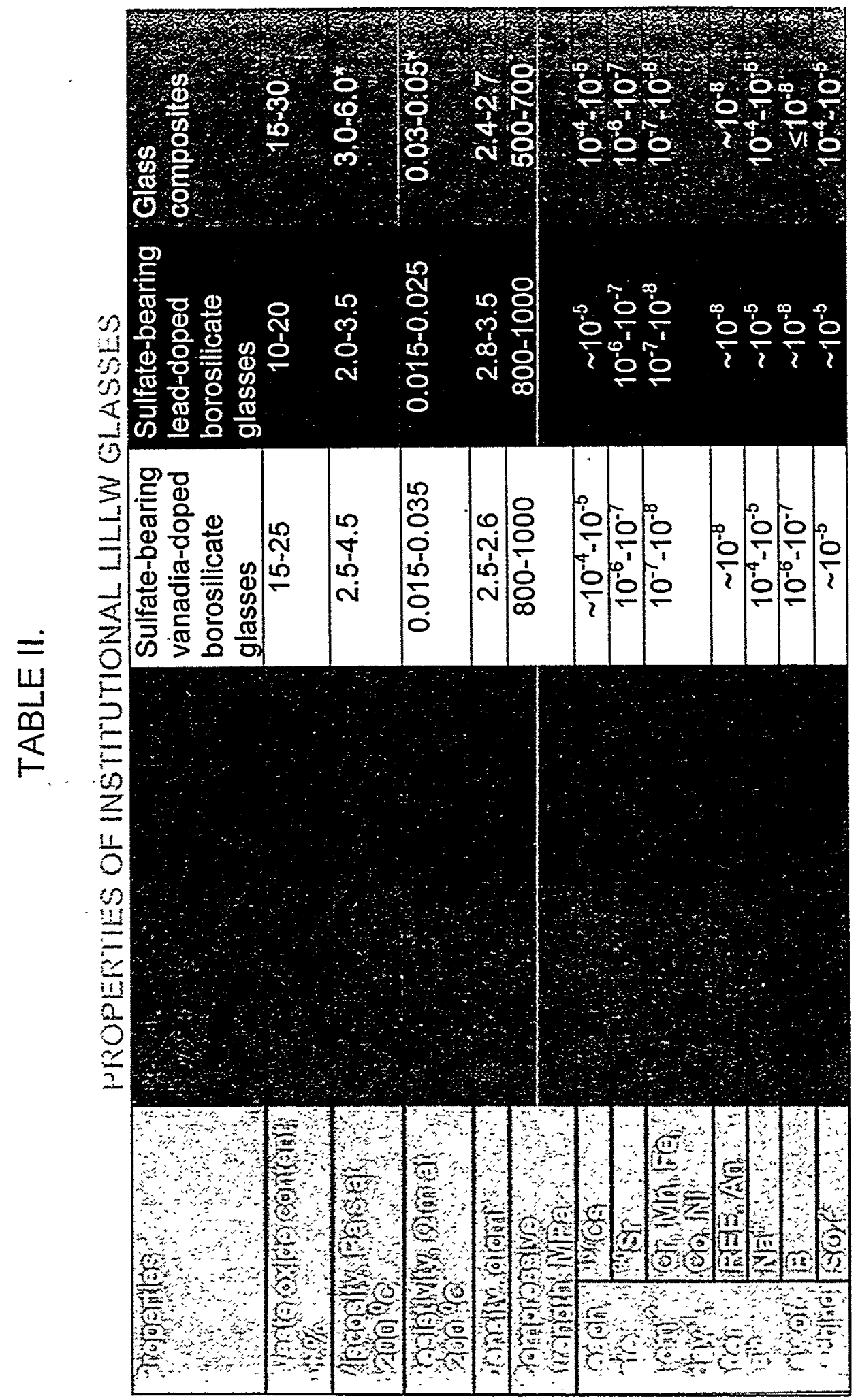


TABLE IV

COMPOSITIONS AND PROPERTIES OF RBMK WASTE GLASSES

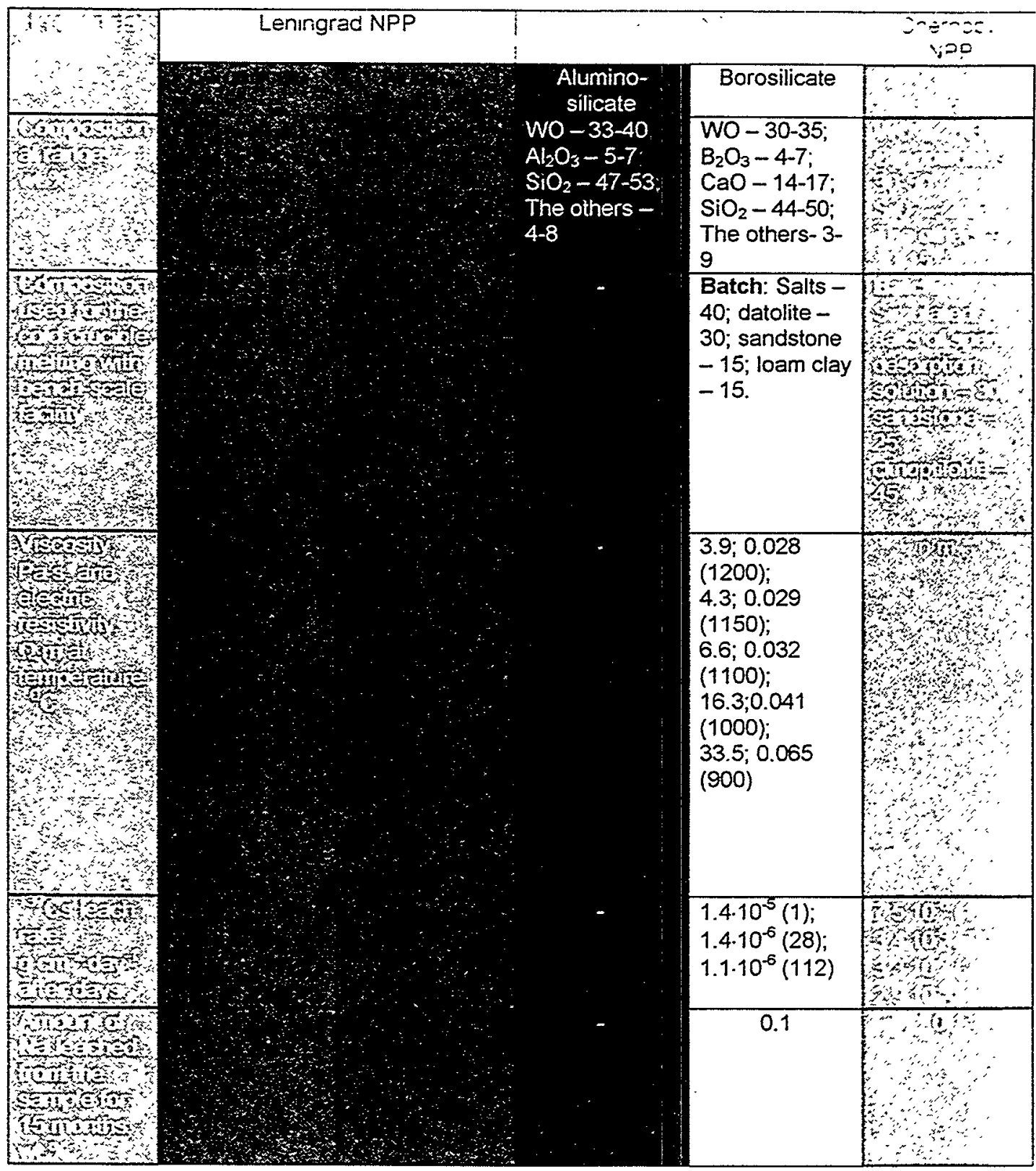

* waste oxide content;

* not measured

*** "yellow phase" was present

$\star \star \star * * \mathrm{Na}$ 


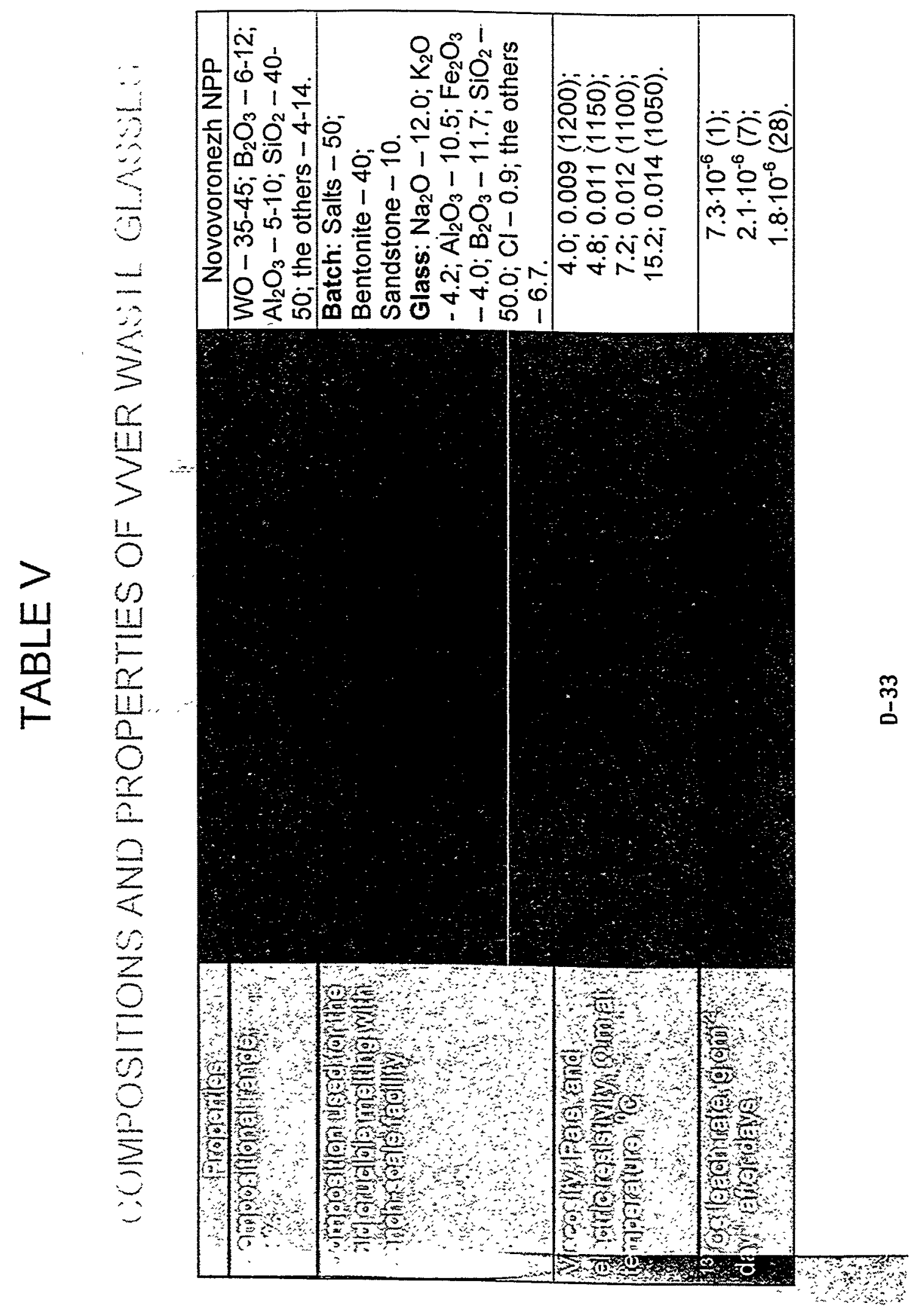




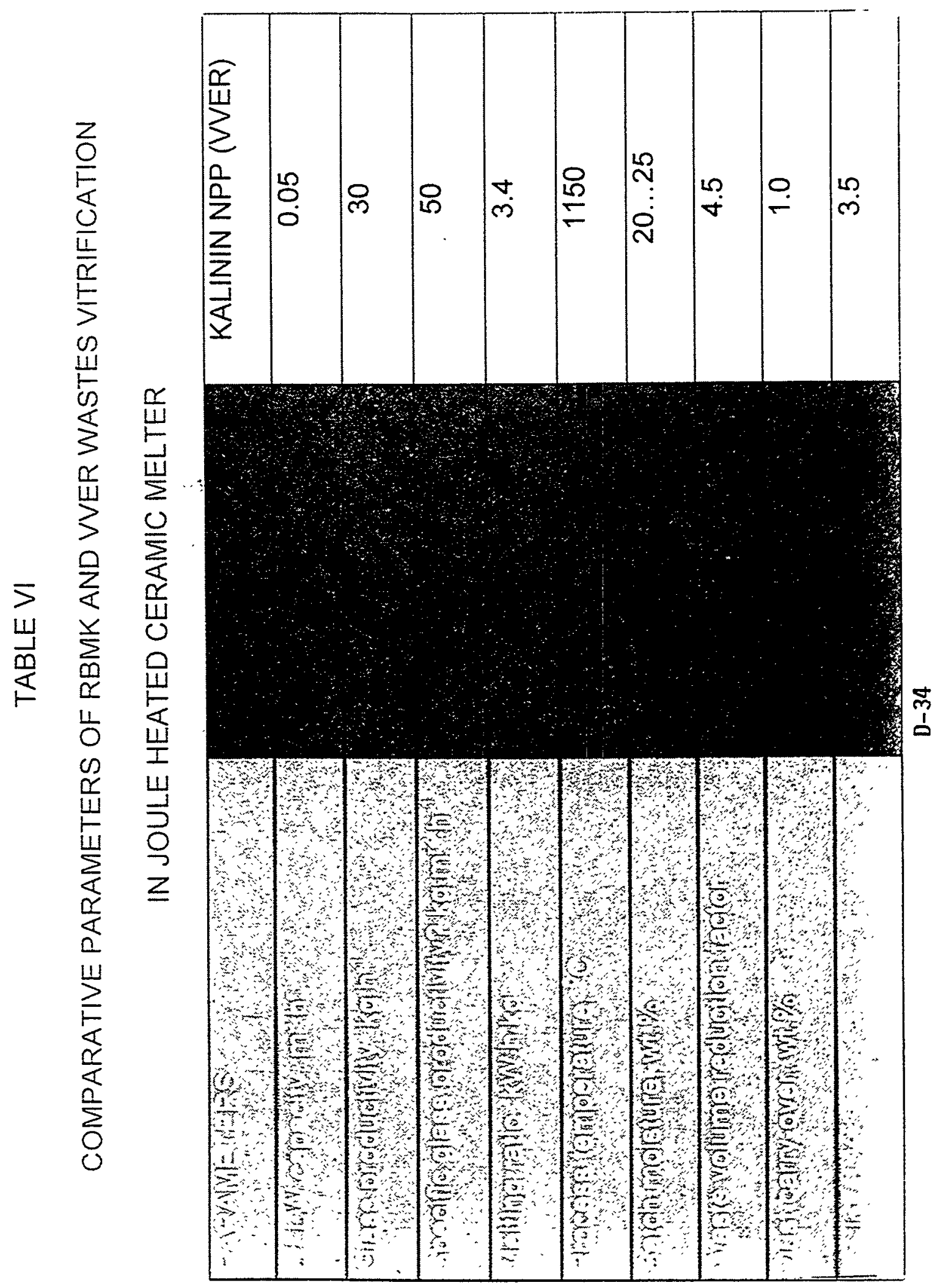




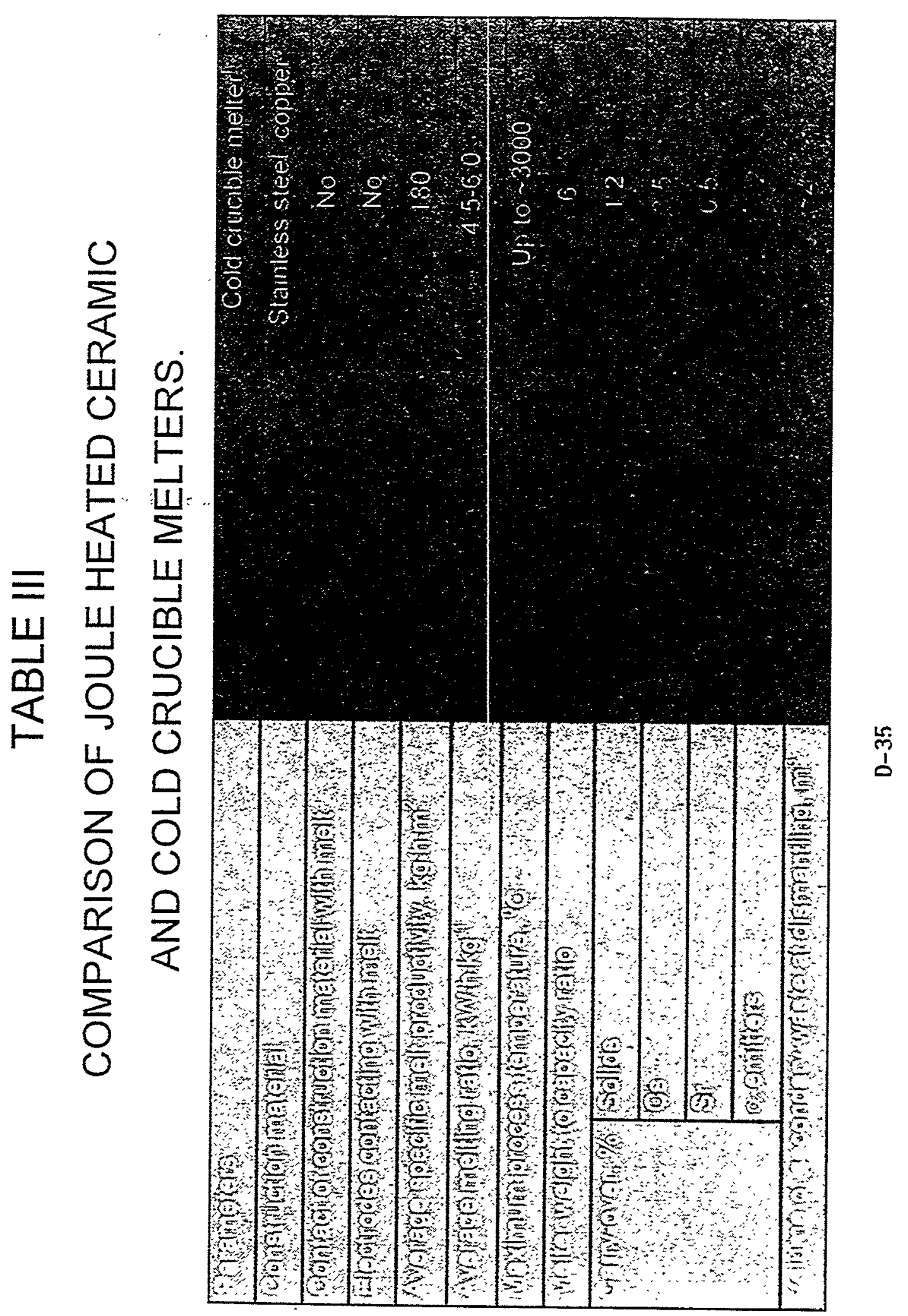




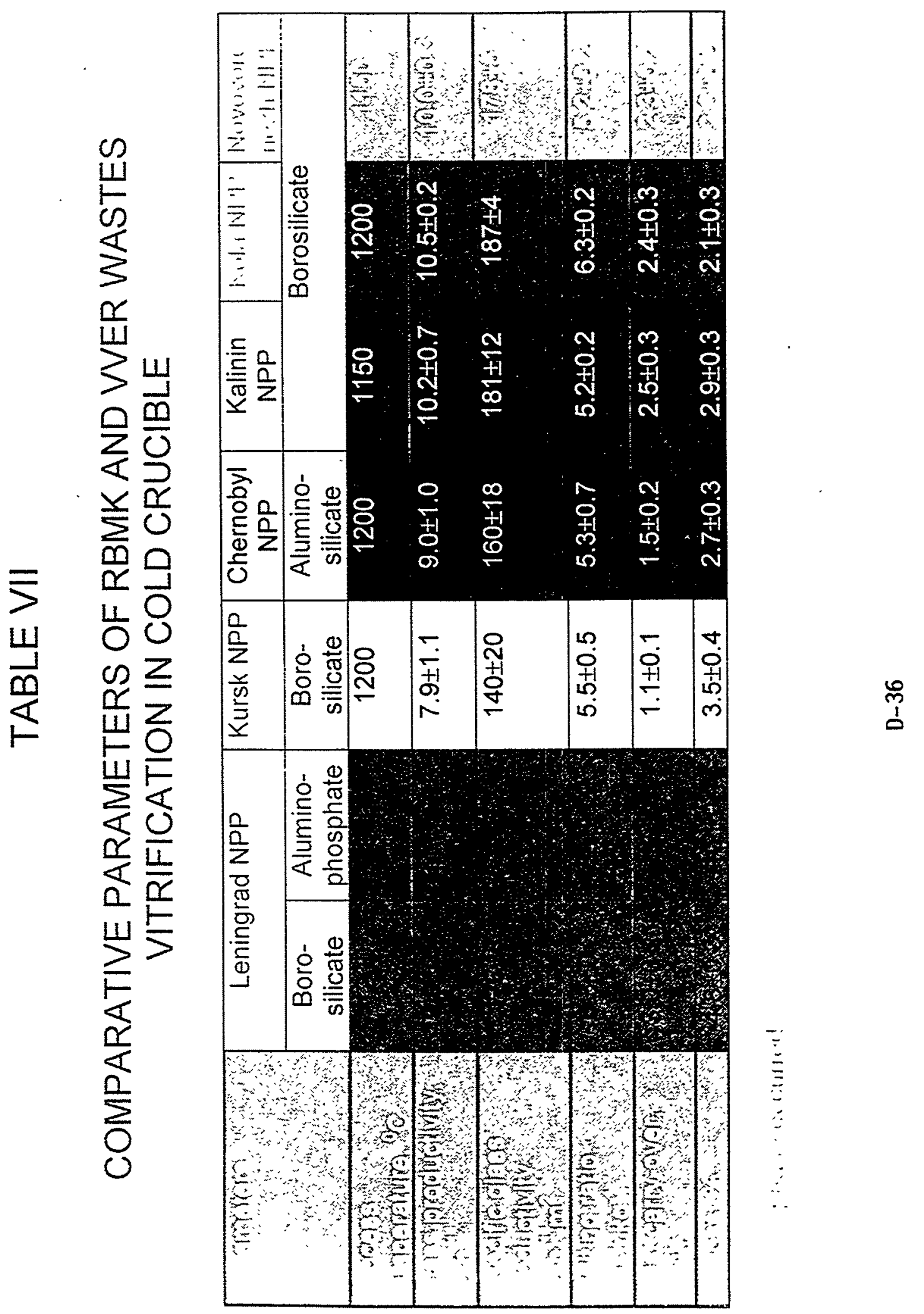




\section{LILLW INCORPORATION IN CERAMICS}

Lab-scale tests on incorporation of Kursk and Kalinin NPP wastes in ceramics were carried out.

Liquid wastes were concentrated and slurries were intermixed with natural raw materials followed by heat-ireatment to $900{ }^{\circ} \mathrm{C}$ at rate of 2 $2.5^{\circ} \mathrm{C} \cdot \mathrm{min}^{-1}$ in a muffle furnace and kept at this temperature for $1-3$ hours. The samples obtained were cooled down to room temperature within the turned-off furnace.

Three samples containing NPP wastes were obtained and no "yellow phase" formation was found.

Up to $\sim 40$ wt.\% of NPP waste salts may be incorporated into ceramics where total amount of sulfate and chloride ions can reach $\sim 5 \mathrm{wt} . \%$ whereas $\sim 2$ wt.\% only may contain in aluminosilicate and borosilicate glasses.

Therefore, this method should be considered as promising to immobilize NPP and other wastes with high sulfate and chloride content. 


\section{TABLE VIII}

COMPOSITIONS OF NATURAL RAW MATERIALS

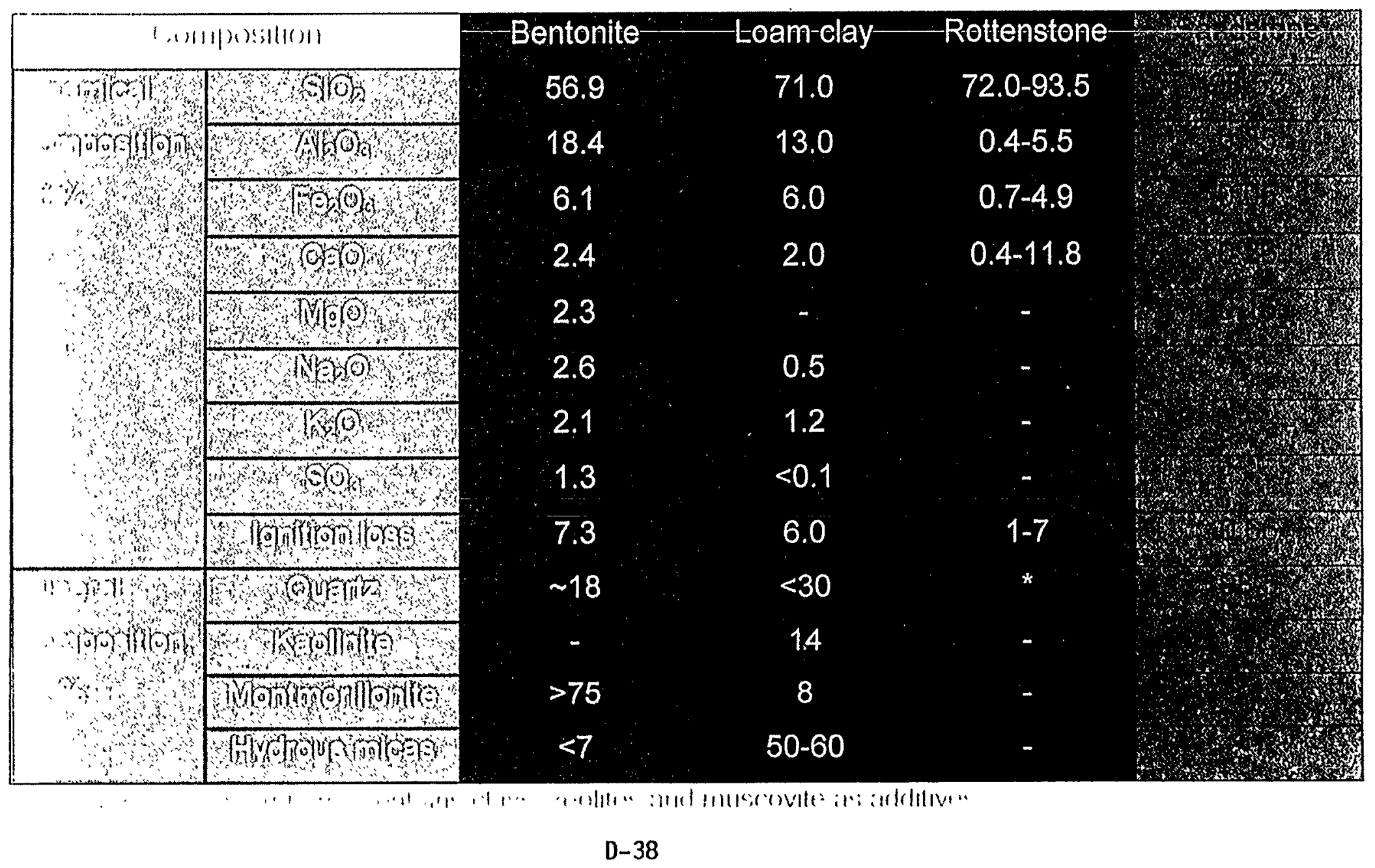


TABLE IX

COMPOSITIONS AND PROPERTIES OF WASTE CERAMICS

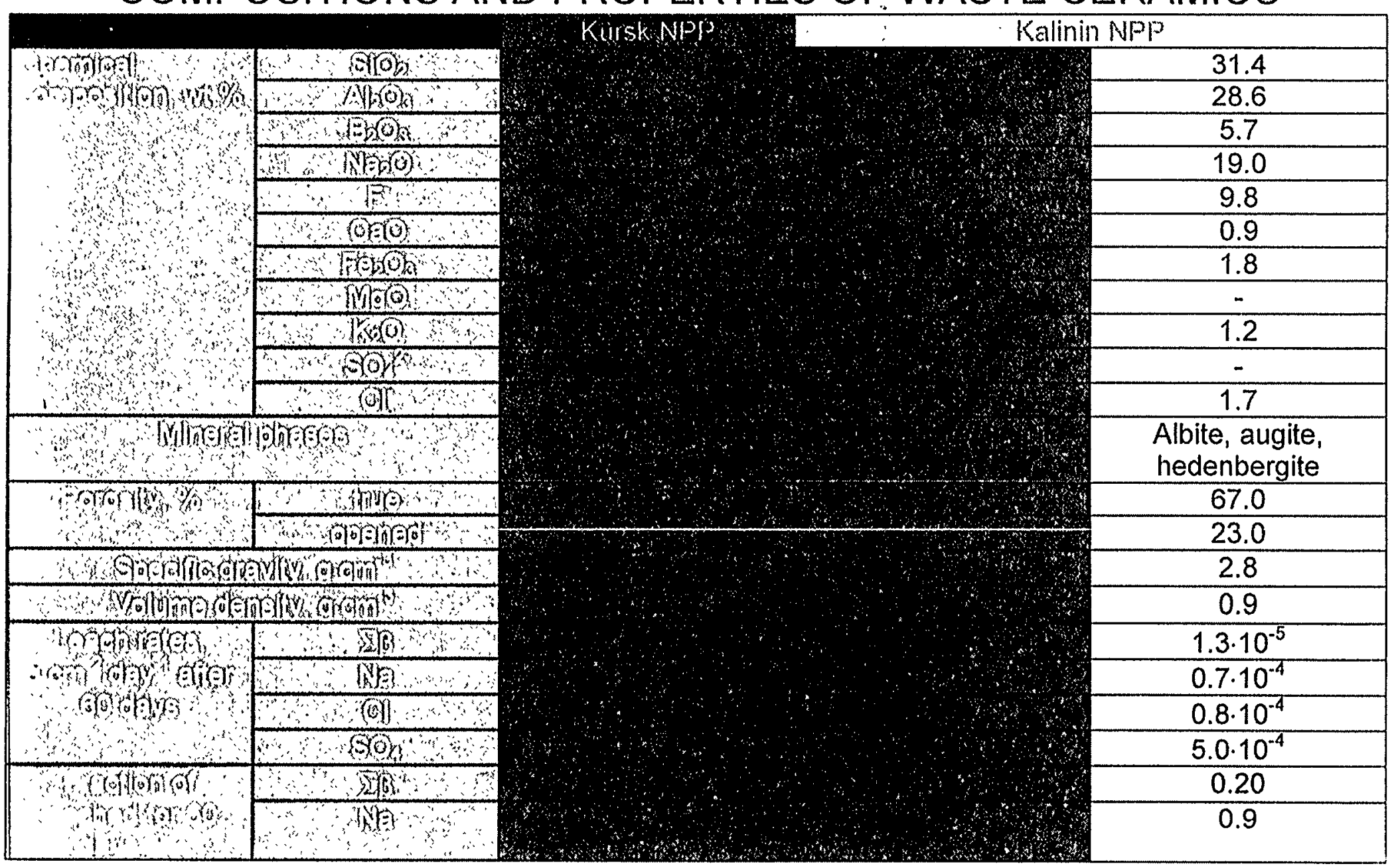

D-39 


\section{IMMOBILIZATION OF SOLID RADIOACTIVE WASTE CONTAINING URANIUM AND PLUTONIUM IN GLASS AND GLASS CERAMICS.}

\section{RADON INCINERATOR ASH}

Chemical composition (wt\%):

2-8 $\mathrm{Na}_{2} \mathrm{O}$

4-18 $\mathrm{Al}_{2} \mathrm{O}_{3}$

$14-38 \mathrm{SiO}_{2}$
$3-9 \mathrm{~K}_{2} \mathrm{O}$

3-33 $\mathrm{FeO}_{\mathrm{n}}$

$<1-4 \mathrm{TiO}_{2}$
8-20 CaO

$<1-2 \mathrm{MnO}$

2-22 $\mathrm{P}_{2} \mathrm{O}_{5}$
3-7 $\mathrm{MgO}$

1-3 $\mathrm{Cr}_{2} \mathrm{O}_{3}$

2-14 ignition loss

(organic residue and carbon).

Specific activity $(\mathbf{B} / \mathbf{k g})$ :

$\beta$ - $\gamma$-emitters $\quad 10^{6}-10^{7}$

$\alpha$-emitters

$10^{6}-10^{8}$

Alpha-emitters: ${ }^{235,238} \mathrm{U},{ }^{239} \mathrm{Pu}$ and ${ }^{241} \mathrm{Am}$.

Maximum concentrations in the vitrified samples:
${ }^{235} \mathrm{U}$
$0.02 \%$,
${ }^{239} \mathrm{Pu}$
$\sim 4.10^{-4} \%$,
${ }^{238} \mathrm{U}$
$2 \%$,
${ }^{241} \mathrm{Am}$
$\sim 5 \cdot 10^{-7} \%$.

Flux additives

no flux (ash)

sodium disilicate $\mathrm{Na}_{2} \mathrm{O} \cdot 2 \mathrm{SiO}_{2}$

sodium trisilicate $\mathrm{Na}_{2} \mathrm{O} \cdot 3 \mathrm{SiO}_{2}$

sodium tetrasilicate $\mathrm{Na}_{2} \mathrm{O} \cdot 4 \mathrm{SiO}_{2}$

borax $\mathrm{Na}_{2} \mathrm{O} \cdot 2 \mathrm{~B}_{2} \mathrm{O}_{3}$
Melting temperature, ${ }^{\circ} \mathrm{C}$

$1400-1500$

$1350-1400$

1400-1500

$1450-1550$

1050-1200

borosilicate frit (glass with $\sim 30-40 \mathrm{wt} \%$ of LILRW oxides) $1250-1350$

dolomite $\mathrm{CaMg}\left(\mathrm{CO}_{3}\right)_{2}$ + loam clay or bentonite (2:1) $1350-1450$ 
PROPERTIES OF ASH-CONTAINING GLASSES

\begin{tabular}{|c|c|c|c|c|c|c|c|}
\hline \multirow{2}{*}{\multicolumn{2}{|c|}{ Properties }} & \multicolumn{6}{|c|}{ Fluxing agents } \\
\hline & & $\begin{array}{l}\mathrm{Na}_{2} \mathrm{O} \\
2 \mathrm{~B}_{2} \mathrm{O}_{3}\end{array}$ & $\begin{array}{l}\mathrm{Na}_{2} \mathrm{O} \\
2 \mathrm{SiO}_{2}\end{array}$ & $\begin{array}{l}\mathrm{Na}_{2} \mathrm{O} \\
3 \mathrm{SiO}_{2}\end{array}$ & $\begin{array}{l}\mathrm{Na}_{2} \mathrm{O} \\
4 \mathrm{SiO}_{2}\end{array}$ & $\begin{array}{l}\text { Boro- } \\
\text { silicate } \\
\text { frit }\end{array}$ & $\begin{array}{l}\text { Dolomite: } \\
\text { Loam clay } \\
\text { (Bentonite) } \\
=2: 1\end{array}$ \\
\hline \multicolumn{2}{|c|}{$\begin{array}{l}\text { Waste oxide } \\
\text { content, wt\% }\end{array}$} & $80-95$ & $60-80$ & $50-80$ & $40-60$ & $50-80$ & $70-85$ \\
\hline \multicolumn{2}{|c|}{$\begin{array}{l}\text { Viscosity, Pa.s, } \\
\text { at } 1300^{\circ} \mathrm{C}\end{array}$} & $3.0-6.0$ & $4.5-8.5$ & $5.0-10.0$ & $5.5-10.0$ & $4.0-8.0$ & $6.0-10.0$ \\
\hline \multicolumn{2}{|c|}{$\begin{array}{l}\text { Resistivity, } \Omega \cdot \mathrm{m} \text {, } \\
\text { at } 1300^{\circ} \mathrm{C}\end{array}$} & $\begin{array}{l}0.025- \\
0.050\end{array}$ & $0.03-0.06$ & $\begin{array}{l}0.04- \\
0.07\end{array}$ & $\begin{array}{l}0.07- \\
0.13\end{array}$ & $\begin{array}{l}0.035- \\
0.075\end{array}$ & $0.04-0.10$ \\
\hline \multicolumn{2}{|c|}{ Density, $\mathrm{g} / \mathrm{cm}^{3}$} & $2.5-2.7$ & $2.5-2.7$ & $2.5-2.6$ & $2.5-2.6$ & $2.5-2.7$ & $2.6-2.8$ \\
\hline \multicolumn{2}{|c|}{$\begin{array}{l}\text { Compressive } \\
\text { strength, } \mathrm{MPa}\end{array}$} & $500-800$ & $700-900$ & $\begin{array}{l}800= \\
1000\end{array}$ & $\begin{array}{l}850- \\
1100\end{array}$ & $750-900$ & $800-1000$ \\
\hline $\begin{array}{l}\text { Leach } \\
\text { rate, }\end{array}$ & ${ }^{137} \mathrm{Cs}$ & $\sim 10^{-5}$ & $10^{-6}-10^{-7}$ & $10^{-6}-10^{-7}$ & $10^{-6}-10^{-8}$ & $10^{-6}-10^{-7}$ & $10^{-7}-10^{-8}$ \\
\hline $\begin{array}{l}g /\left(\mathrm{cm}^{2} .\right. \\
\text { day })\end{array}$ & ${ }^{90} \mathrm{Sr}$ & $\sim 10^{-6}$ & $\sim 10^{-8}$ & $\leq 10^{-8}$ & $\leq 10^{-8}$ & $10^{-7}-10^{-8}$ & $\leq 10^{-8}$ \\
\hline $\begin{array}{l}\text { on } 28^{\text {th }} \\
\text { day }\end{array}$ & ${ }^{239} \mathrm{Pu}$ & $\leq 10^{-8}$ & $\leq 10^{-8}$ & $\leq 10^{-8}$ & $\leq 10^{-8}$ & $\leq 10^{-8}$ & $\leq 10^{-8}$ \\
\hline
\end{tabular}

ANALYTICAL METHODS (in cooperation with Khlopin Radium Institute - Dr.

A. Aloy and co-workers):

- X-ray diffraction (XRD),

- differential thermal analysis (DTA),

- transmission electron microscopy (TEM),

- electron microprobe analysis (EMPA)

Total weight loss. after heating to $1000{ }^{\circ} \mathrm{C}$ 


\section{XRD DATA}

Source incinerator ash:

$\beta$-whitlockite $\mathrm{Ca}_{3}\left(\mathrm{PO}_{4}\right)_{2}$,

hydroxylapatite $\left.\mathrm{Ca}_{10}\left(\mathrm{PO}_{4}\right)_{6}\left[(\mathrm{OH})_{2}, \mathrm{CO}_{3}\right)\right]$,

calcite $\mathrm{CaCO}_{3}$,

quartz $\mathrm{SiO}_{2}$,

plagioclase,

amorphous phase.

Source ash heated to $1000^{\circ} \mathrm{C}$ :

$\beta$-whitlockite,

hydroxylapatite,

potassium aluminosilicates kalsilite $\mathrm{KAISiO}_{4}$ and leucite $\mathrm{KAISi}_{2} \mathrm{O}_{6}$, quartz.

Source ash after heating to $1450{ }^{\circ} \mathrm{C}$ :

$\beta$-whitlockite,

vitreous phase.

Vitrified ash melted at $1450{ }^{\circ} \mathrm{C}$ with dolomite-bentonite flux:

Nagelschmidtite $\mathrm{Ca}_{7}\left(\mathrm{PO}_{4}\right)_{2}\left(\mathrm{SiO}_{4}\right)_{2}$

amorphous phase. 
Vitrified samples is inhomogeneous.

The sample vitrified with dolomite-bentonite flux was found to be more homogeneous compared to samples of vitrified unfluxed ash.

\section{Waste elements distribution:}

- Sections are depleted and enriched with $\mathrm{Ca}, \mathrm{P}$, and $\mathrm{Si}$.

- Some Cr-rich inclusions.

- Matrix glass contains $\mathrm{K}, \mathrm{Al}, \mathrm{Fe}$, and Si.

- It confirms XRD data showing occurrence of whitlockite or nagelschmidtite.

- These minerals are host phases for $\mathrm{Sr}$, rare earths, Th, and $U$, and probably another actinides (Pu, $\mathrm{Am})$.

- $\mathrm{Cr}$-rich inclusions are possibly $\mathrm{Cr}$-containing spinel that was not detected by XRD due to very small content. These may concentrate $\mathrm{Mn}, \mathrm{Fe}$, and $\mathrm{Co}$. 
FULL-SCALE LIQUID WASTE VITRIFICATION PLANT

The main constituent of liquid waste is $\mathrm{NaNO}_{3}(200-600 \mathrm{~g} / 1)$.

Another components

- cations: $\mathrm{K}, \mathrm{Ca}, \mathrm{Mg}, \mathrm{Al}, \mathrm{Fe}, \mathrm{Cr}$, etc.

- anions: carbonates, borates (in Nuclear Power Plant waste with VVER), sulfates, chlorides.

TABLE I. Batch Compositions (wt.\%).

\begin{tabular}{|c|c|c|c|c|c|}
\hline $\begin{array}{c}\text { No } \\
\cdot\end{array}$ & Waste & Waste & Datolite & Sandstone & Bentonite \\
\hline 1 & Moscow Station & $35-50$ & $25-35$ & $10-20$ & $10-15$ \\
\hline 2 & NPP with RBMK & $30-45$ & $25-40$ & $10-20$ & $10-20$ \\
\hline 3 & NPP with VVER & $45-60$ & - & $15-30$ & $20-30$ \\
\hline
\end{tabular}

Starting melt in the crucible is formed by an inductive heating of magnetite paste poured on the batch surface charged into the crucible. At first only small melt volume is formed to initiate an inductive heating. After starting melt formation, heating of the whole bulk is continued until whole charge is melted, following by batch feeding.

Melt capacity

Melt surface area in the crucible

The number of cold crucibles

Specific capacity

Maximum capacity

Waste loading

${ }^{137} \mathrm{Cs}$ leach rate

Waste volume reduction factor up to $25 \mathrm{~kg} / \mathrm{h}$

$0,15 \mathrm{~m}^{2}$

$3 . . .4$

up to $167 \mathrm{~kg} / \mathrm{m}^{-2} \cdot \mathrm{h}^{-1}$

up to $75 \mathrm{~kg} / \mathrm{h}$

$30 . . .40$ wt. $\%$

$10^{-5}-10^{-6} \mathrm{~g} \mathrm{~cm}^{-2}$ day $^{-1}$

3-5. 


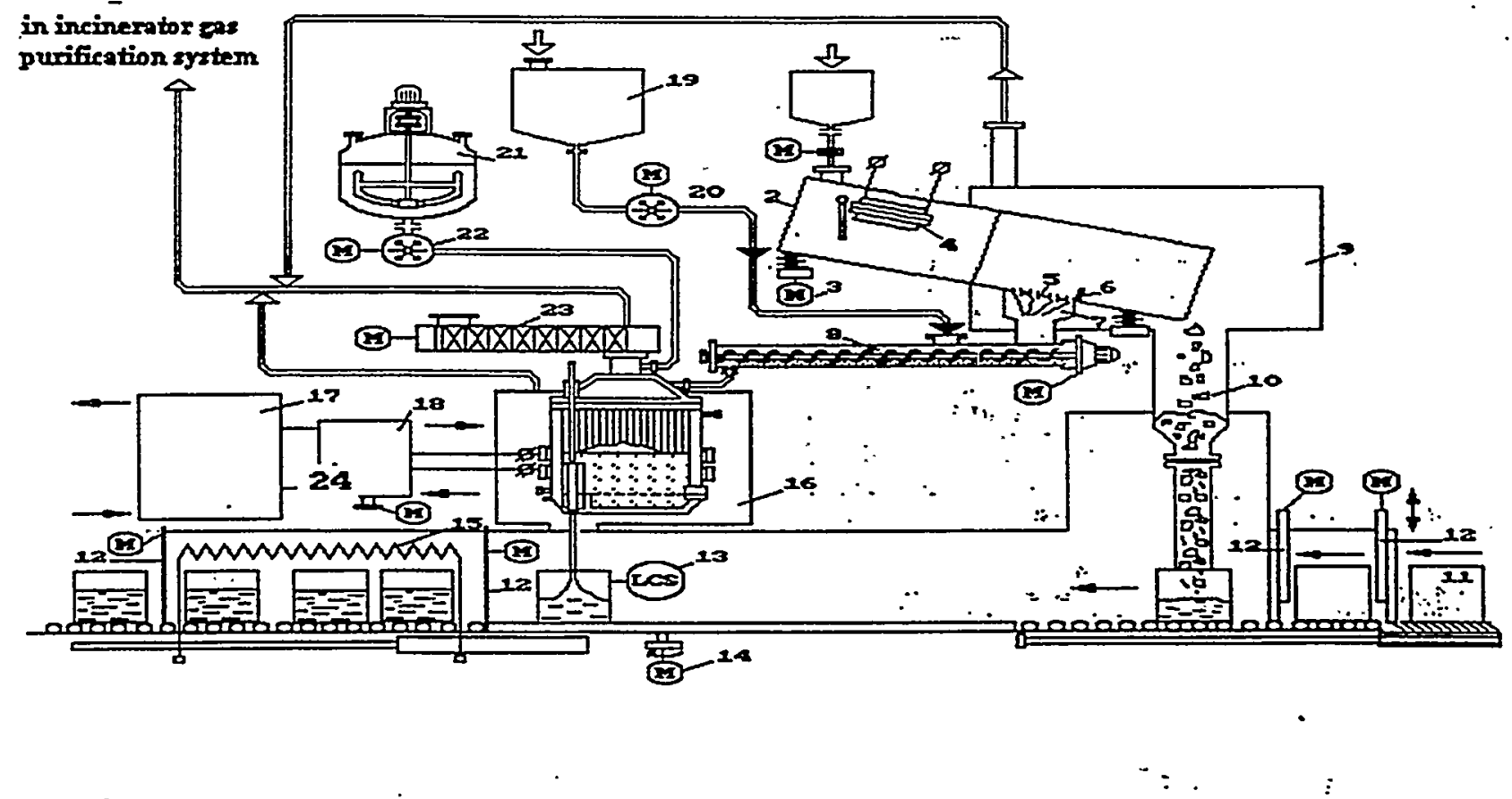

1.Asher; 2.Conveyer-classifier, 3.Vibrator, 4.Electromagnet; 5.Separator, 6.Lif blind 7.Inlet connection 8.Screw conveyer-mixer; 9. Techinological box;, 10.Receving box; 11.Container;" 12.Dammer; 13.Glass Level. Detector, 14. Convèyér drive; is. Electric radiator, 16.Cold crucible;; 17.Hf generator, 18:Load block; :19.Glass formers tank; 20,22.Feeders; 21.Starting material vessel; 23.Magazine of filters;24.Annealing furnance.

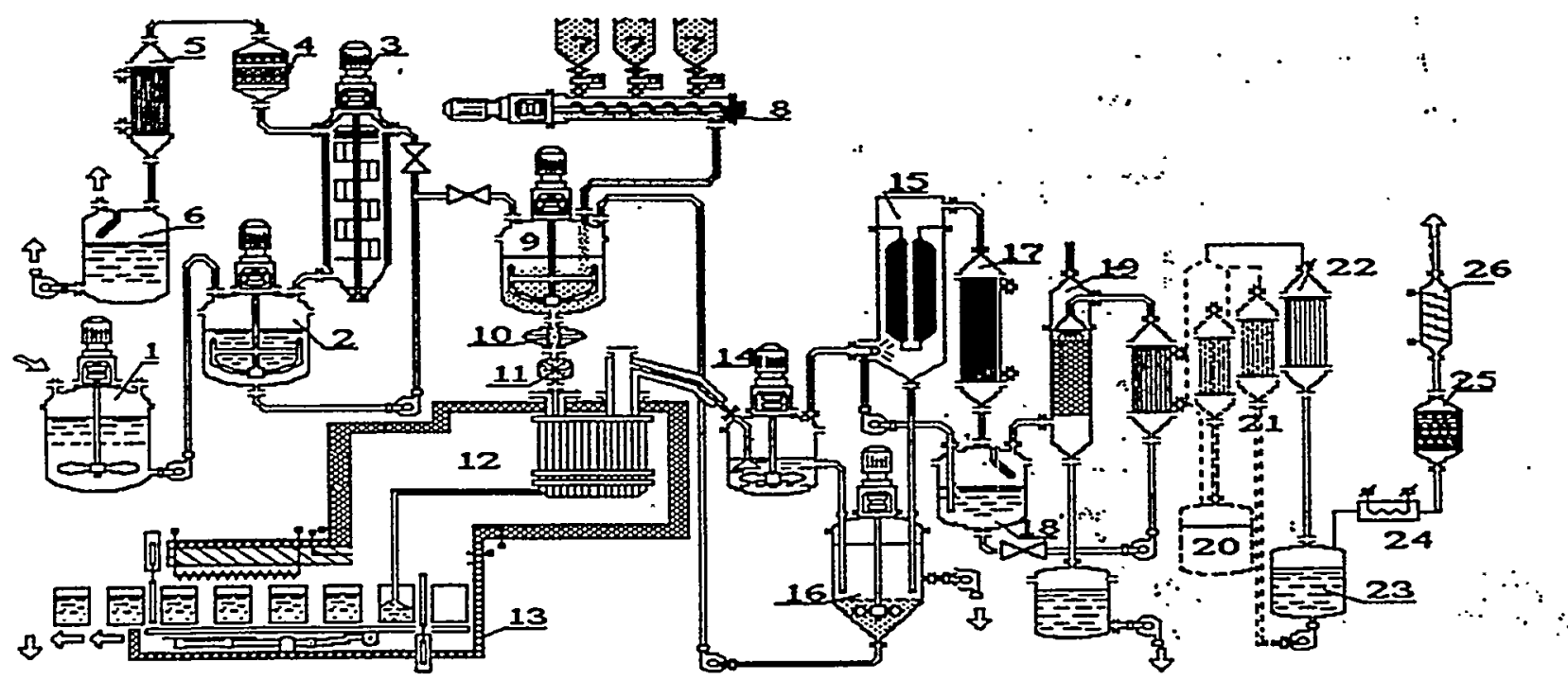

1 - waste storage tank. 2 - concentrated waste tank. 3 - rotary evaporator. 4,26-filtcrs. 5,17,21,22 - heat exchangers. 6,16,20-collectors. 7 -glass formers. 8 - screw. 9 - batch mixer. 10 - apparaus for mechanical activation. 11 - charging fedder. 12 - melters. 13 - anneäling furnace. 14 -coarse (mesh) filter. 18,23-reservoirs. 19 - absorption column. 24 - heater. 25 -reactor for catalitic decomposition of $\mathrm{NO}_{\mathrm{x}}$ 


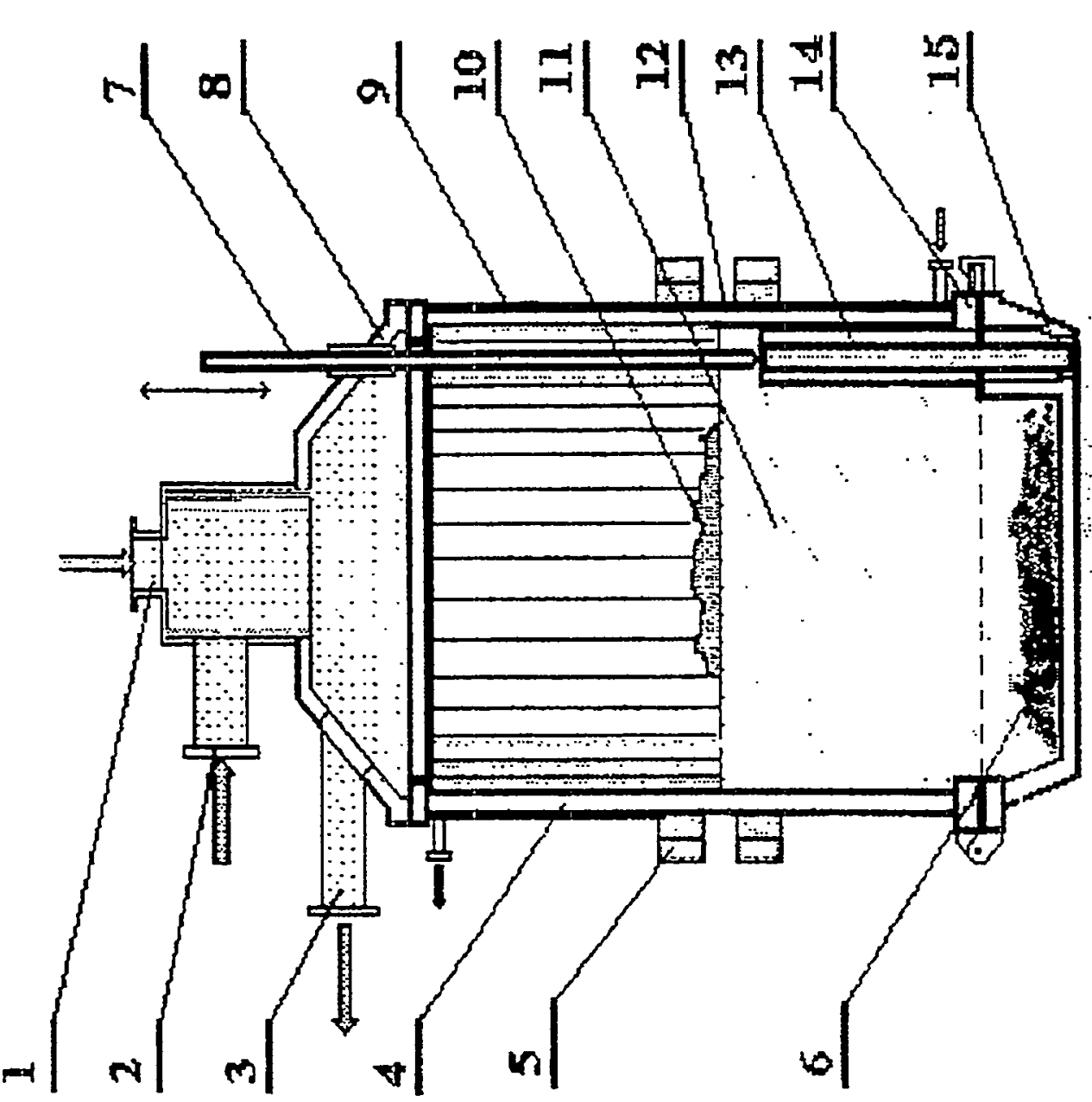

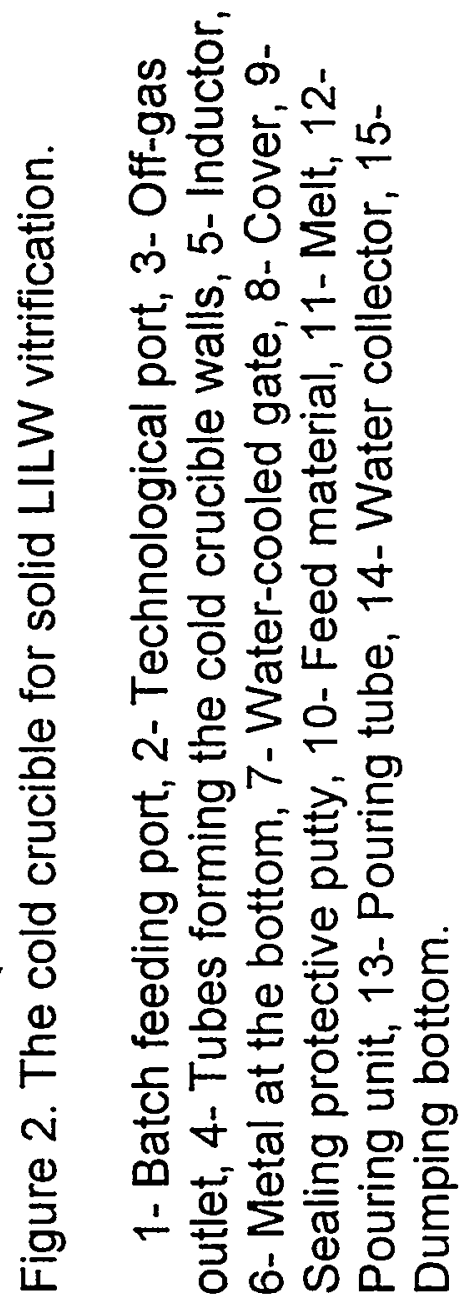

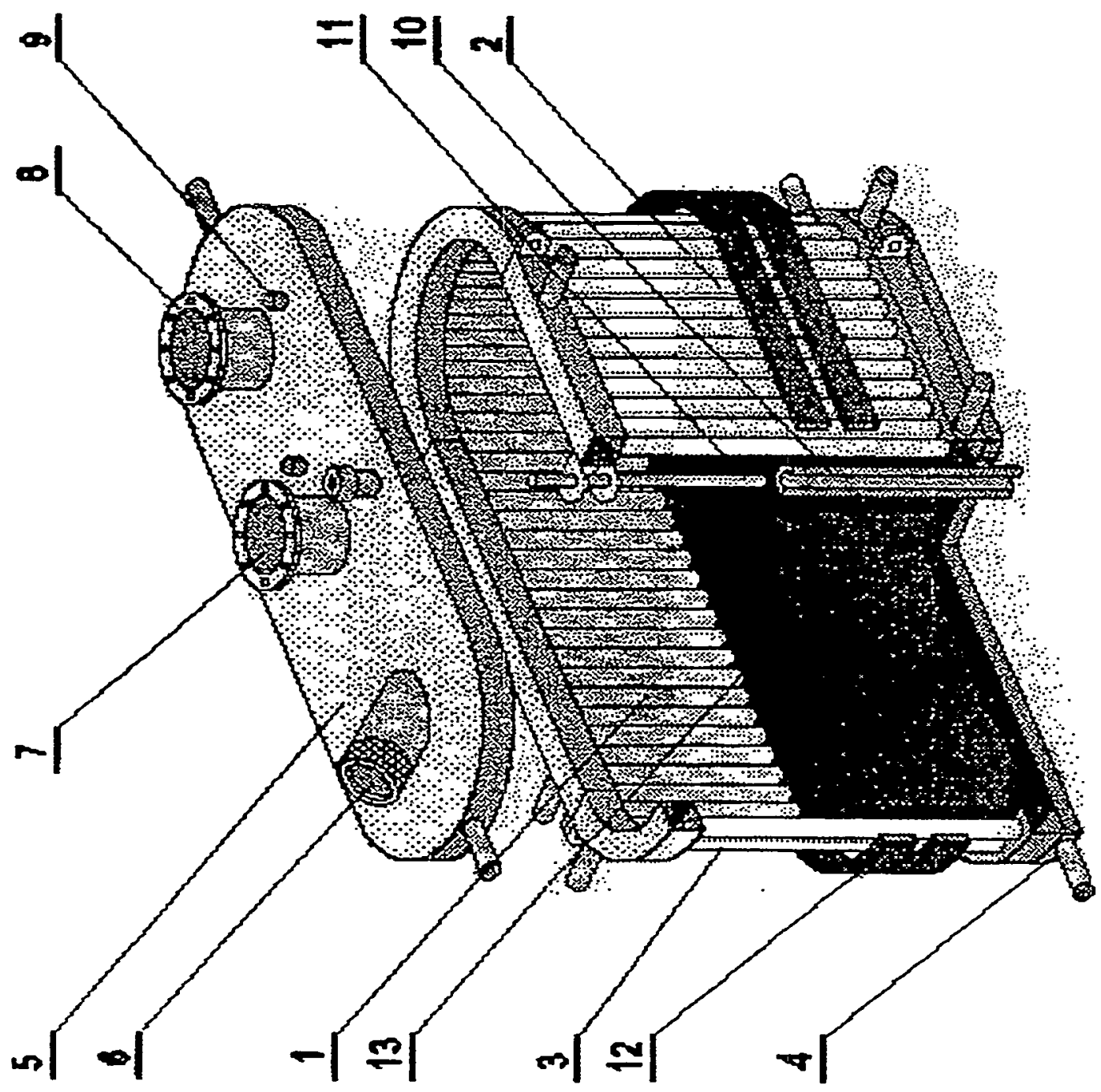

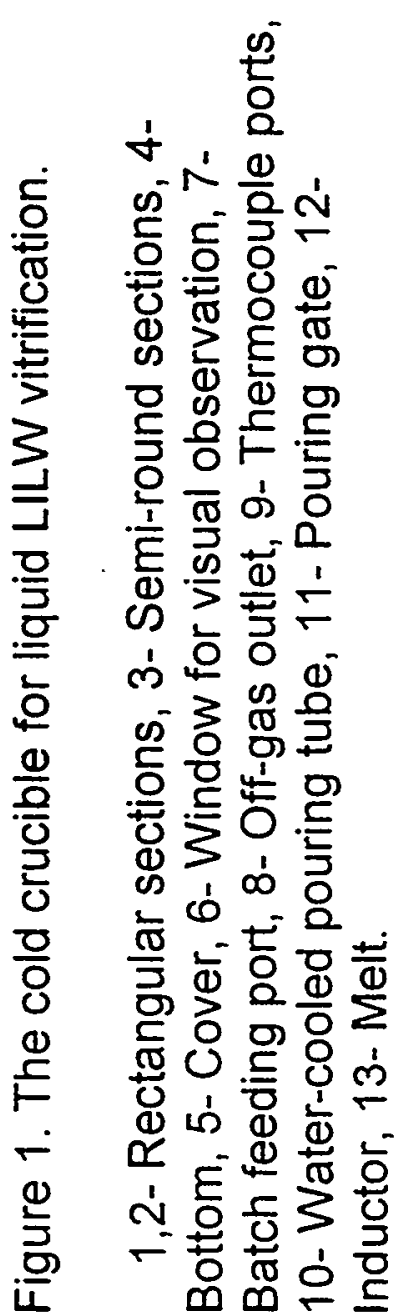




\section{CHARACTERIZATION OF THE OFF-GAS SYSTEM}

\begin{tabular}{|c|c|c|c|}
\hline \multicolumn{2}{|c|}{ Off-gas volume rate, $\mathrm{m}^{3} / \mathrm{h}$} & Up to 100 & \multirow{9}{*}{ 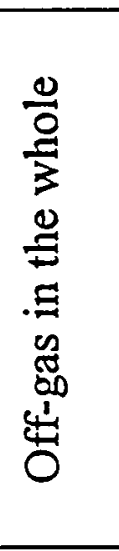 } \\
\hline \multirow{2}{*}{$\begin{array}{l}\text { Off-gas } \\
\text { temperature, }{ }^{0} \mathrm{C}\end{array}$} & Inlet & Up to 200 & \\
\hline & Outlet & $<50$ & \\
\hline \multirow{2}{*}{$\begin{array}{l}\text { Aerosol concentra- } \\
\text { tion, } \mathrm{Bq} / \mathrm{dm}^{3}\end{array}$} & Inlet & $<15$ & \\
\hline & Outlet & $<0,015$ & \\
\hline \multirow{2}{*}{$\begin{array}{l}\text { Dust concentration, } \\
\mathrm{mg} / \mathrm{m}^{3}\end{array}$} & Inlet & Up to 2000 & \\
\hline & Outlet & $<0,02$ & \\
\hline \multirow{2}{*}{$\begin{array}{l}\mathrm{NO}_{\mathrm{x}}, \text { concentration } \\
\mathrm{g} / \mathrm{m}^{3}\end{array}$} & Inlet & Up to 70 & \\
\hline & Outlet & $<0,01$ & \\
\hline \multicolumn{2}{|c|}{ Filtration area, $\mathrm{m}^{2}$} & 2,7 & \\
\hline \multicolumn{2}{|c|}{ A number of filtering sleeves } & 9 & \\
\hline \multicolumn{2}{|c|}{ Filtering slleve length, $\mathrm{m}$} & 1 & \\
\hline \multicolumn{2}{|c|}{ Filtering sleeve diameter, $\mathrm{m}$} & 0,1 & \\
\hline \multicolumn{2}{|c|}{ Inlet aerosol concentration, $\mathrm{mg} / \mathrm{m}^{3}$} & 5 & \\
\hline \multicolumn{2}{|c|}{ Temperature, ${ }^{\circ} \mathrm{C}$} & до 200 & 荌 \\
\hline \multicolumn{2}{|c|}{ Sleeve life time, months } & 6 & $\mathbb{D}$ \\
\hline \multirow{3}{*}{$\begin{array}{l}\text { Regeneration } \\
\text { system }\end{array}$} & Compressed air pressure, atm & 6 & ఫี \\
\hline & Compressed air rate, $\mathrm{m}^{3} / \mathrm{h}$ & 10 & \\
\hline & Power, W & 200 & \\
\hline \multicolumn{2}{|c|}{ Overall dimensions, $\mathrm{mm}$} & $1400 \times 600 \times 600$ & \\
\hline \multicolumn{2}{|l|}{ Weight, $\mathrm{kg}$} & 200 & \\
\hline \multicolumn{2}{|l|}{ Filtration area, $\mathrm{m}^{2}$} & 2,6 & \\
\hline \multicolumn{2}{|c|}{ A number of filtering sleeves } & 1 & \\
\hline \multicolumn{2}{|c|}{ Filtering sleeve length, $\mathrm{m}$} & 1 & $\frac{\mathscr{Q}}{2}$ \\
\hline \multicolumn{2}{|c|}{ Filtering sleeve diameter, $\mathrm{mM}$} & 0,64 & 4 \\
\hline \multicolumn{2}{|l|}{ Life time, months } & 6 & 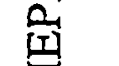 \\
\hline \multicolumn{2}{|l|}{ Overall diameter, $\mathrm{mm}$} & $800 \times 800 \times 1800$ & \\
\hline \multicolumn{2}{|l|}{ Weight, $\mathrm{kg}$} & 200 & \\
\hline \multicolumn{2}{|c|}{ Reflus density, $\mathrm{m}^{3} /\left(\mathrm{m}^{2} \mathrm{~h}\right)$} & 8 & \\
\hline \multicolumn{2}{|l|}{ A number of columns } & 3 & .0롤 \\
\hline \multicolumn{2}{|c|}{$\mathrm{NO}_{\mathrm{x}}$ outlet concentration, $\mathrm{mg} / \mathrm{m}^{3}$} & 2000 & 言言 \\
\hline \multicolumn{2}{|c|}{ Overall dimensions, $\mathrm{mm}$} & $350 \times 350 \times 1700$ & 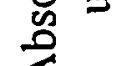 \\
\hline Weight of the colum & with packing, $\mathrm{kg}$ & 75 & \\
\hline A number of operatir & g sections & 3 & \\
\hline A number of cooling & sections & 3 & $\frac{0}{0}$ \\
\hline Off-gas rate $\mathrm{m}^{3} /\left(\mathrm{m}^{2} \mathrm{l}\right.$ & & 10000 & 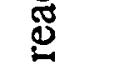 \\
\hline $\mathrm{NO}_{\mathrm{x}}$, outlet concentr: & tion, $\mathrm{mg} / \mathrm{m}^{3}$ & $<10$ & $\stackrel{0}{=}$ \\
\hline Catalyst life time, $\mathrm{m}$ & nths & 12 & $\frac{\pi}{\pi}$ \\
\hline Overall dimensions, & & $1850 \times 540 \times 540$ & $\pi$ \\
\hline Weight of the reactor & with catalyst, $\mathrm{kg}$ & 250 & \\
\hline
\end{tabular}




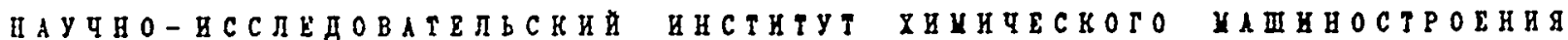

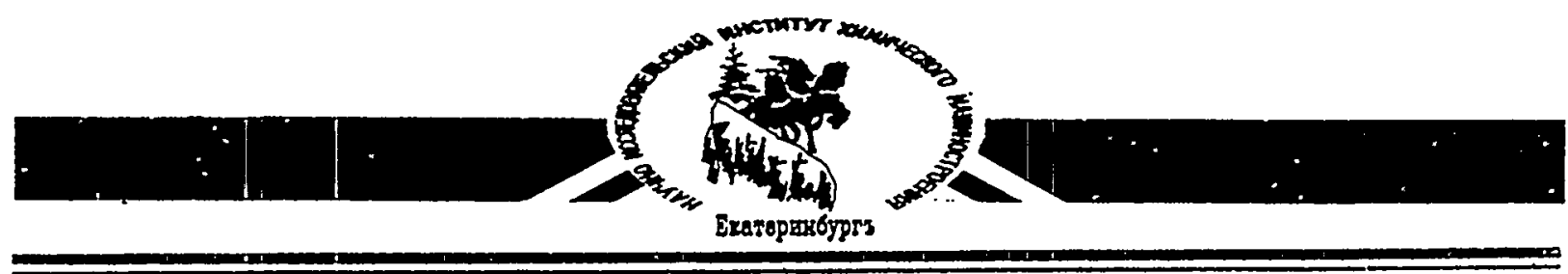

\section{УСТАНОВКИ ОСТЕКЛОВЫВАНИЯ ВЫСОКОАКТИВНЫХ ОТХОДОВ}

\section{HIGH-LEVEL RADIOACTIVE WASTE VITRIFICATION INSTALLATION}

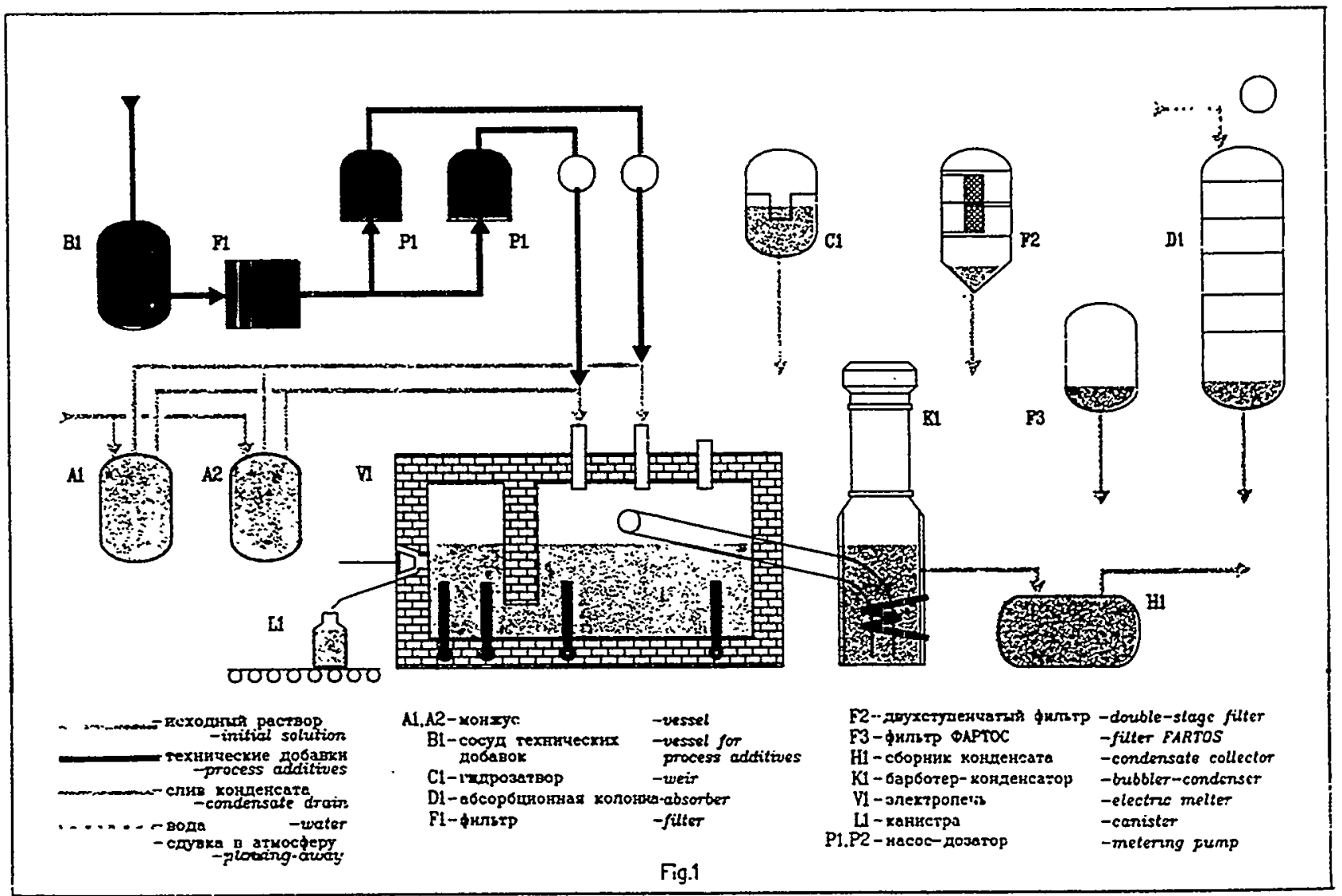

В Российской Федерации разработаны и испытаны установки остекповывания высокоактивных отходо8.образуюlиихсл от регенерации ядерного топпива.

Основным аппаратом этих установок явпяется эпектропечь прямого нагсева /ЭП/. Установки имеют производительность 100 и $\angle C O \mathrm{n} / 4$ по высскоактиеным отходам.

Помимо электропечей установки имеют системы дозировзния отходов и Флюсуюших добавок.конденсаиии вторичных паров и очистки сбростых газов.а также системы расФасовки стекломассы в 200-литровые канистры.установпенные на гснеейере. п поспедующим помещением канистр в герметичные пемалы и транслортировки пенапов во временное храмиличе в защитном контейнере.

На figl приведена принципиальная схема устеновки сстекпивьвания.а на fig.2 - эпектропечь остекловывания. Ineктропечь рассчитана на попучение фосфатного стекпа 8 качестве Флюе используется ортоФосФорная кислота В случае получения боросиликатного стекла устанобка снабмается дополнительным узпом дозирования порошка либо ¿устензии өпюсviощих nо6авок.

"становка остекловывания /fig.1/ имеет узлы дозирования жидких радиоактивных отходов и Флюсүюших добавок,узлы расфасоеки стекпомассы и аппараты системы газоочистки.
In the Russion Federation there were develcped and tested the installations for high-level radioactive woste vitrification. which were formed at nucleor fuel reprocessing. The main unit of these instollations is 0 direct heoted electric melter /EM/. The output of the instollations amounts to 100 and $400 \mathrm{l} / \mathrm{h}$ or high level wostes

Aport from electric 'melters such instollations hove measuring systems for wastes ord fluxira additives. secondary steam condensotion and off-gos treotment.os well os the systems for glass moss pouring into 200-liter conisters. installed on the conveyer. with their subsequent putting into tight boxes ons transporting the boxes into a temporory siorone in shielding container

Schematic diogrum of the vitrificotion installation is given in fig.l and thot of the electric melter - in fig 2. The electric melter is desigred for phosrihnte gloss production Orthophosphoric ocis is uses os a fluxing ogent. In cose of borosilicote gloss aroduction the installation is equipped with on adcitionol unit for meosuring of powder or suspension of the fluxing additives 
Поспедние позволпют уловить из паро газового потока теердые настицн.радионуклиды. В тон числе рутенийокси-

ды азота и получить на выходе газы,очиценыые до концентраций вредных принесей миже предегоно допустимых Hopm.

Как эиднс из fig.2. зпектропечь имеет две зоны: варочнус 2 и накопительную 5. Зоны раз̆делены перегородкой с донным перетоком 3. 0бе зоны обогреваются раздельныни гборками злектродов 11,через которье подводится переменный злектрический ток к расппаву стекпа. Спив пориии ¿rеклсмассы производится через сливное отверстие. закDып аемое охлаждаеной пробкой. Печь рабстает под разреЖениен. пюши, срок работы ее опредепен в 3 года.

2 габпиче приведены основные характеристики двух модичикаиий электропечей. Опытная электропечь эП-і00 прошла ммггопетние испытания на имитаторах отходов $c$ добавленьем небольших количеств рапионукпидов и послужиле проободзом промышлемной злектропечи $3 П-500$

компоновка оборудования установки выполнена по 3-зомному примцилу. необспуживаемая зомаполуобслуживаеная и обслуживаемая.

На заводе по регенераиии ядерного топпива работает прочышленная электропечь ЭП-500. На ней переработаны отхоपы Сумнарной активностью оноло $40 \mathrm{~A}$ н.К.Кк.

Накопленный опыт позволяет создавать установки с электрспечами задамной производитепьности в диапазоне от 50 до $500 \mathrm{n} / 4$ no жидкин радиоактивным отходам.
: хсда из опыта и снорости коррозии основных материалов

The vitrification installation /fig.1/ comprises the units for metering liquid rodiooctive wostes and fluxing additives. for glass mass pocking and opporatus for off-gas treatment. The latter allows to catch solid porticles. rodionuclides including ruthenium nitrogen oxides from steam-gas flow and to obtain gases at the outlet decontaminoted up to the concentrotions of impurities lower than the permissible standards.

As it is seen from fig 2 the electric melter consists of two zones: a melting one 2 and on occumulation one 5. The zones ore separoted by a boffle with bottom overflow 3. Both zones are heoted by separate assemblies of electrodes 11. through which olternating current is supplied to the gloss melt Droining of o glass mass portion is corried out through a drain opening being closed by o plug being cooled. The melter operates under vocuum.

In terms of the experience and corrosion rate of the melter construction moteriols its service liie is detined to be three years.

The moin specifications of two types of electric melters are given in Table. The pilot electric melter $3 \Pi-100$ underwent persistent tests on waste imitotors with the addition of small quontities of nucliaes and served as a prototype of the industriol electric melter $37-500$.

The installotion equipment arrongement is fulfilled according to the three-zone principle not being maintoined one. being semimaintained one and being maintoined.

At the works for nuclear fuel reprocessing there operotes the industrial electric melter $30-500$ Wostes with the totol radiooctivity level nearly $40 \mathrm{mln} \mathrm{Ci}$ are processed in it

The experience occumulated mokes it possible to develop installations with electric melters with the design output in the ronge from 50 to $500 \mathrm{l} / \mathrm{h}$ on liquid radionctive wastes.

\footnotetext{
1-кладке печи -molter brickworks

2-варочная зона -melting zone

3-переток -оver-flow

4-водоохлахнаемие трубы перетоко -overflow water-cooled tubes 5-накопительвав зона

- accumaulation zone

6-стеклокасса -glaiss. mass

7-перекрытие печи (свод)

-meiter erch

8-охлаждаеная пробка

9-лоток

-plug being cooled

10-газоход

- 11-злектроди

-trey

-gas duct

-electrodes
}

Ta6nuua

Характеристики зпектропечей

\begin{tabular}{|c|c|c|c|}
\hline Основные показатели & $37-100$ & $3 \pi-500$ & Parameter \\
\hline 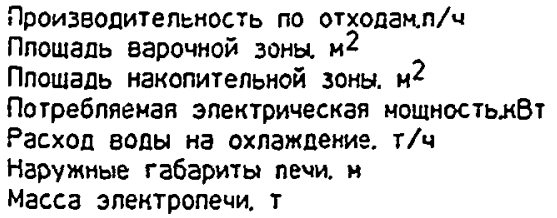 & $\begin{array}{l}100 \\
1.9 \\
1.4 \\
200 \\
40 \\
6.5 \times 2.5 \times 31 \\
22\end{array}$ & $\begin{array}{l}400 \pm 100 \\
10.7 \\
1.8 \\
850 \\
100 . .150 \\
9.5 \times 4.2 \times 3.2 \\
172\end{array}$ & $\begin{array}{l}\text { Output on wastes. is } \\
\text { Helting zone area } \mathrm{m}^{2} \\
\text { Accumulation zone crea. } \mathrm{m}^{2} \\
\text { Electric power consumed. } \mathrm{kW} \\
\text { Cooling woter flow rote. } \mathrm{t} / \mathrm{h} \\
\text { Melter outer dimensions. } \mathrm{m} \\
\text { Electric melter moss. ? }\end{array}$ \\
\hline
\end{tabular}

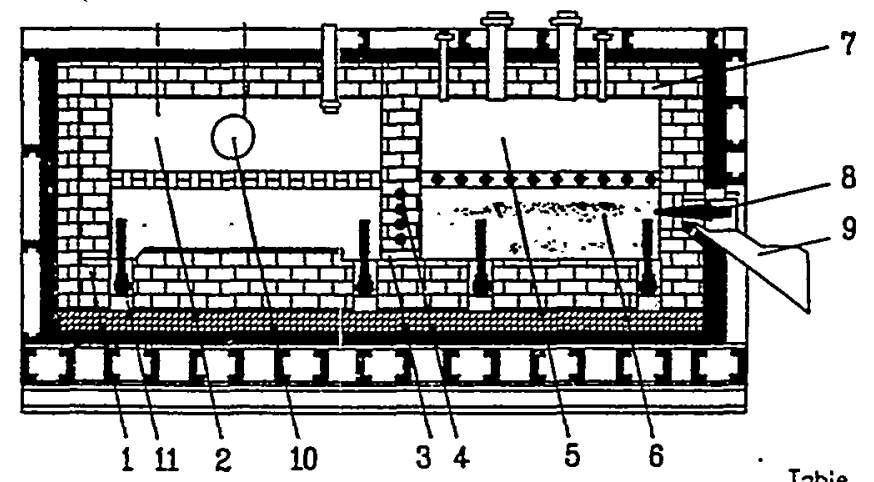

Tobie

Fig.2 - Electric melter specificotions
Haш aдpec:

Россия 620010

г Екатеринбург, ул Грибоедова 32

Телефон (3432) 2\%4-430

Tereфакс (3432) 275-505

телетай 221301 "Cосна"
Our addross:

32 Griboedov str Ekaterinburg 620010 Russia

Phone (3432) 274-430

Fax (3+32) 275-505

Type 221301 "Sosna" 
ONE OF THE ROCK-TYPE MATRICES IS TITANATE CERAMICS CALLED "SYNROC" HAS BEEN SUGGESTED AND DEVELOPED IN AUSTRALIA USING THE HOT·PRESSING METHOD.

\section{SYNROC}

MAJOR PHASES:

Hollandite $\mathrm{BaAl}_{2} \mathrm{Ti}_{6} \mathrm{O}_{16}$

Perovskite $\mathrm{CaTiO}_{3}$,

Zirconolite CaZrTi2 $\mathrm{O}_{7}$.
MINOR PHASES:

CAT phase

Hibonite $\mathrm{CaAl}_{12} \mathrm{O}_{19}$

Metal Alloy

\section{Rutile $\mathrm{TiO}_{2}$}

The technology of Synroc production consists of the following basic operations:

- $\mathrm{HLW}$ mixing with water suspension containing powdered $\mathrm{TiO}_{2}, \mathrm{ZrO}_{2}, \mathrm{Al}_{2} \mathrm{O}_{3}, \mathrm{CaO}$ and $\mathrm{BaO}$,

- dehydration,

- drying,

- denitration

- calcination of the mixture in a rotary calciner at a temperature of $7500^{\circ} \mathrm{C}$,

- addition of metallic titanium powder to the mineralized product in the amount up to 2 wt.\%,

- hot pressing of the product in special moulds with subsequent annealing at $1200^{\circ} \mathrm{C}$.

The newest elaborations envisage preparation of a homogeneous charge, the so-called Synroc precursor, using sol-gel process [Radioactive Waste Form for the Future, 1988. P.233-334]. 


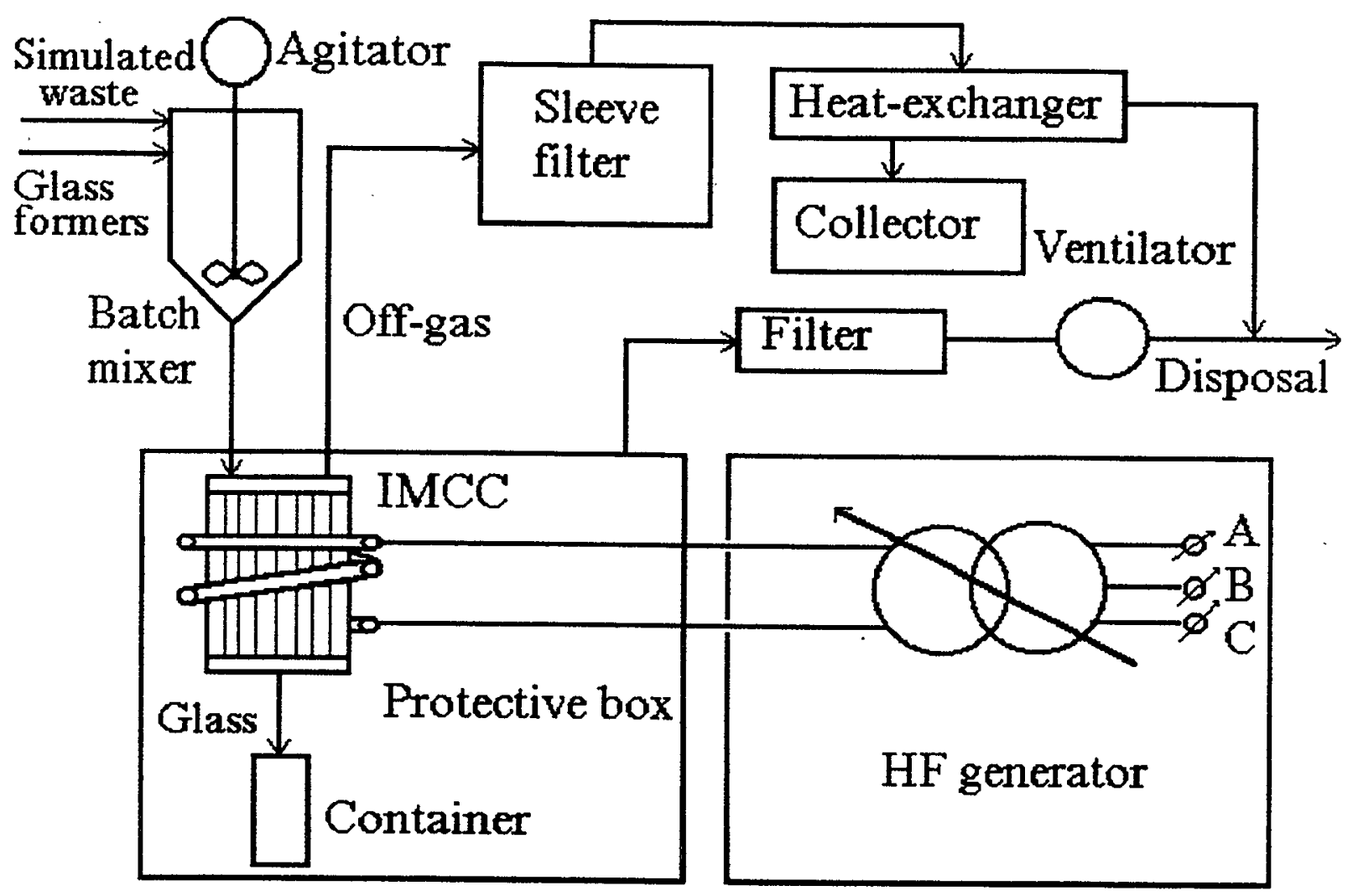

Figure 1. Block Diagram of Experimental Plant with "Cold Crucible".

\begin{tabular}{|c|c|c|c|c|c|}
\hline \multicolumn{2}{|c|}{ The cold crucible dimensions } & \multicolumn{3}{c|}{ HF generator parameters } \\
\hline & $\begin{array}{c}\text { For tests } \\
\text { \#1,2 }\end{array}$ & $\begin{array}{c}\text { For tests } \\
\text { \#-5 }\end{array}$ & & $\begin{array}{c}\text { For tests } \\
1,2\end{array}$ & $\begin{array}{c}\text { For tests } \\
\text { \#-5 }\end{array}$ \\
\hline Length & $590 \mathrm{~mm}$ & - & Frequency & $1.76 \mathrm{MHz}$ & $1.76 \mathrm{MHz}$ \\
\hline Width & $300 \mathrm{~mm}$ & - & Power & $160 \mathrm{~kW}$ & $60 \mathrm{~kW}$ \\
\hline Height & $655 \mathrm{~mm}$ & $150 \mathrm{~mm}$ & & & \\
\hline Diameter & - & $100 \mathrm{~mm}$ & & & \\
\hline $\begin{array}{c}\text { Melt surface } \\
\text { area }\end{array}$ & $10.18 \mathrm{dm}^{2}$ & $0.8 \mathrm{dm}^{2}$ & & & \\
\hline
\end{tabular}

Container dimensions: $400 \times 400 \times 150 \mathrm{~mm}$

Batch properties:

Particle size

$\leq 10 \mathrm{~mm}$

Moisture

$\cong 20 \mathrm{wt} . \%$

Feed portions

$0.5-1 \mathrm{~kg}$ 


\section{SYNROC-TYPE CERAMICS}

Works were started in 1990.

\section{STEP 1}

ORIGINAL PURPOSE: to prove formation of the Synroc-type ceramics at the cold crucible melting.

\section{MAJOR SYNROC PHASES:}

Hollandite,

Zirconolite,

Perovskite,

Rutile 1 .

\section{MINOR PHASES:}

Powellite $\mathrm{CaMoO}_{4}$, Hibonite/Loveringite, CAT-phase.

ANALYTICAL METHODS (in cooperation with Institute of Ore Deposits Geology, Mineralogy, Petrography and Geochemistry of Russian Academy of Sciences (IGEM) and ANSTO, Australia):

Optical microscopy

SEM/TEM

EMPA.

Fast neutron irradiation.

No cracking and elevated leaching were found after of the melted Synroc-C carried out at ANSTO.

\footnotetext{
${ }^{1}$ I.A. SOBOLEV, S.V. STEFANOVSKY, F.A. LIFANOV, Radiochemistry (Russ.) 35 (1993) 99-106.
} 
Synroc is titanate-based ceramics developed in Australia and consisting of minerals

- ZIRCONOLITE (CAZRTI ${ }_{2} \mathrm{O}_{7}$,

- HOLLANDITE $\left(\mathrm{BAAL}_{2} \mathrm{TI}_{6} \mathrm{O}_{16}\right)$,

- PEROVSKITE (CATIO ${ }_{3}$ ),

- RUTILE (TIO $)_{2}$.

The most conventional method of the Synroc production is hot-pressing at

\section{- $1150-1200{ }^{\circ} \mathrm{C}$ \\ - 14-21 MPA.}

Alternative method of the Synroc production based on inductive "skull" melting in a cold crucible has been proposed in Russia at the end of the 1980s.

The main advantages of the cold crucible over the other melters are

- high temperature availability,

- long lifetime,

- small overall dimensions,

- high capacity.

- no contact of the melt with crucible walls due to "skull" formation, and

- active hydrodynamic flow.

\section{AIM}

DETAILED CHARACTERIZATION OF THE MELTED SYNROC IN COMPARISON WITH THE HOT-PRESSED SYNROC

This work was performed under cooperation between SIA "RADON" (RUSSIA) AND ANSTO (AUSTRALIA). 
Melting ratio was decreased by a factor of 3 and may be explained by the following reasons:

- an increase of the batch melting rate due to the additional heat of exothermic oxidation of metallic titanium;

- relatively low melt level (inside diameter to melt height ratio in the crucible were $110 / 51=2.16$ );

- more depth of the melt heating.

The complete operating cycle is shown in Table II.

\section{Product characterization}

In both experiments the appearance of quenched and slowly cooled materials was similar.

- The most dense and gas free samples were produced at the melt quenching and in the upper part of the slowly cooled block.

- Zones formed below the upper rim and near the crucible bottom, are saturated with gas bubbles.

- The largest crystals are located in the central part of the block removed out of the crucible and smallest crystals are formed in the quenched samples and upper rim.

- The crystal dimensions ranged between the few microns in quenched samples and 1-1.5 mm at the central part of the bulk.

- Material produced under oxidizing conditions consisted of mineral assemblage of zirconolite, hollandite, perovskite and minor rutile and powellite $\mathrm{Ca}(1-\mathrm{x}) \mathrm{Sr}_{\mathrm{x}} \mathrm{MoO}_{4}$.

- Material produced under essentially reducing conditions did not contain the powellite phase and did not exhibit a chemical durability problem.

-A comparison of the leach rates of cesium, strontium, neodymium and molybdenum of materials produced under oxidizing and reducing conditions and measured according to IAEA technique is shown in Table III. 
SYNROC-C doped with 20 wt. $\%$ simulated spent fuel reprocessing waste from LWR-type reactors (microphotograph of thin section, transparent light, crossed nicols, magnification $75^{x}$ )

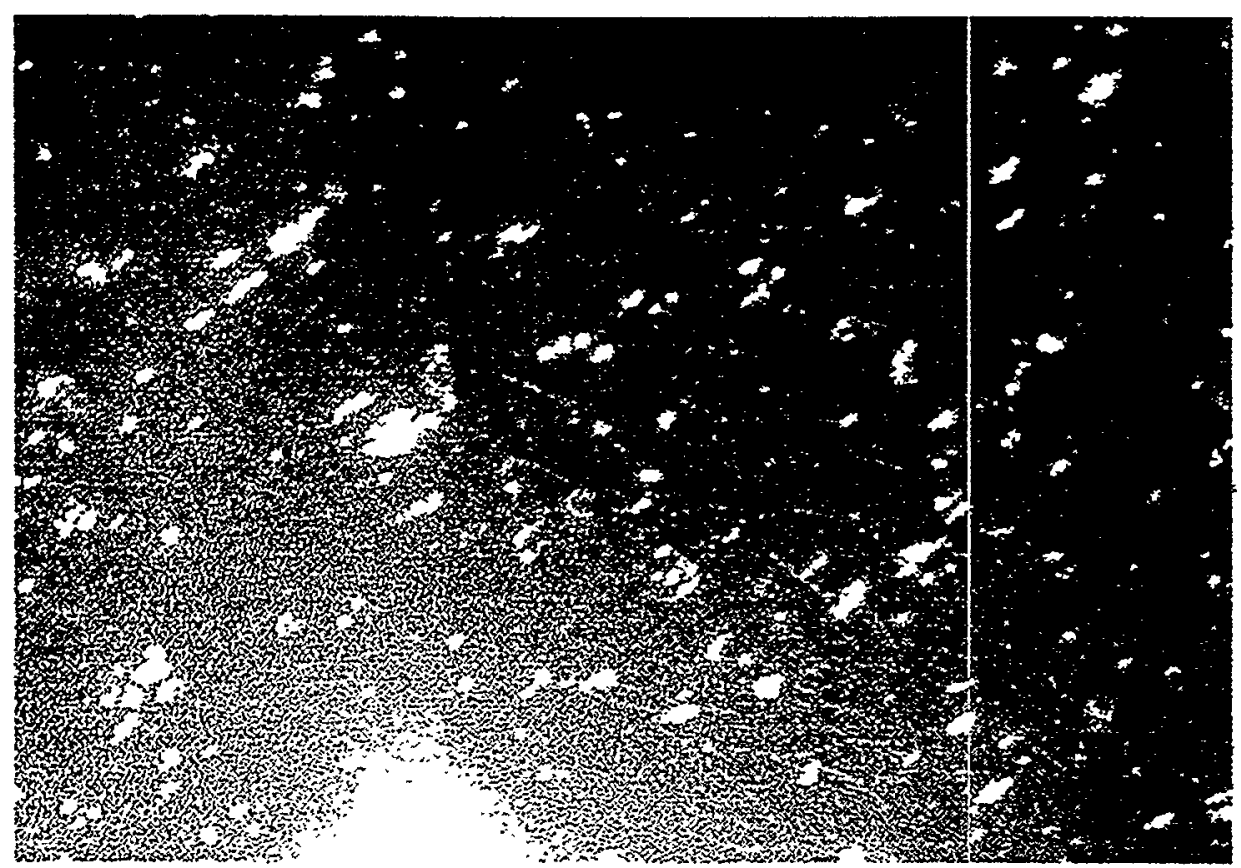

a. Obtained by hot-pressing method at ANSTO (Australia) from sol-gel precursor.

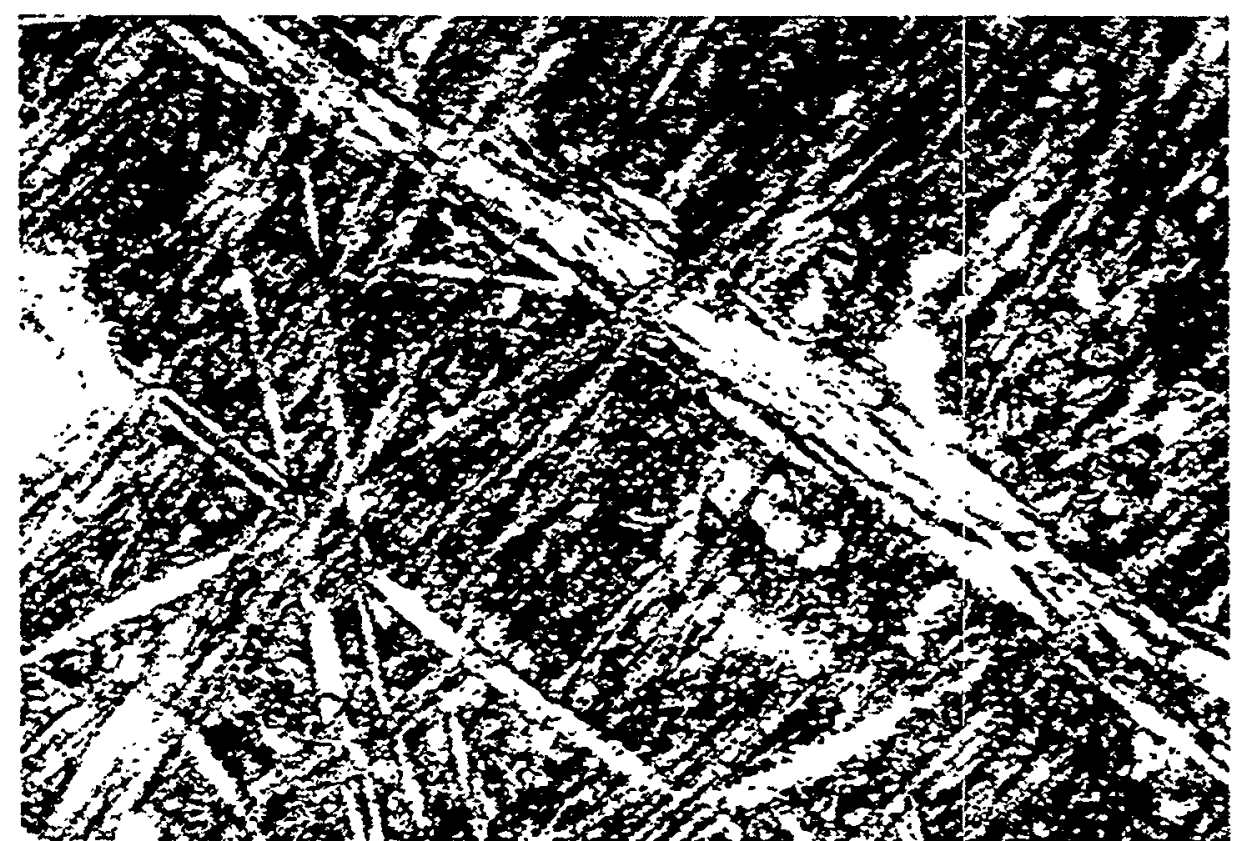

b. Obtained by cold crucible indictive melting technique at SIA "RADON" (Russia) from the same initial mixture. 
Samples characterization

\begin{tabular}{|c|c|c|}
\hline$\overline{\mathbf{A P}}$ & $\mathbf{A M}$ & $\mathbf{R M}$ \\
\hline $\begin{array}{l}\text { Black color, } \\
\text { Glass-like appearance, } \\
\text { Conchoidal fracture, } \\
\text { Unctuous glance, } \\
\text { Transparent spots of } \\
0.01 \text { to } 0.05 \text { mm in size } \\
\text { - rutile with zirconolite } \\
\text { admixture, Rare } \\
\text { inclusions up to } 10 \mu \mathrm{m} \\
\text { - Ni }(70 \%)-F e(30 \%) \\
\text { alloy }\end{array}$ & $\begin{array}{l}\text { Dark-gray color, } \\
\text { Conchoidal fracture } \\
\text { Weak silky glance, } \\
\text { Grainsize from } \\
\text { fractions of } \mathbf{m m} \text { to } 5 \\
\text { mm, } \\
\text { Cavities present, Major } \\
\text { phases: hollandite } \\
(30 \%), \text { rutile }(30 \%), \\
\text { zirconolite }(20 \%), \\
\text { perovskite }(\mathbf{2 0} \%) .\end{array}$ & $\begin{array}{l}\text { Gray color, } \\
\text { Cavities from fractions } \\
\text { of mm to } 3 \mathrm{~mm} \text { in size, } \\
\text { Crystal size - from } 0.1 \\
\text { to } 2 \mathrm{~mm} \text {, } \\
\text { Major phases: } \\
\text { hollandite }(35-40 \%) \text {, } \\
\text { zirconolite }(25-30 \%) \text {, } \\
\text { perovskite }(30-35 \%) \text {, } \\
\text { rutile (<10\%). } \\
\text { Minor phases: } \\
\text { Cs,Ba,Cs-Molybdates, } \\
\text { Hibonite, } \\
\text { CAT-phase }\end{array}$ \\
\hline
\end{tabular}

Crystal chemical formulae of the Synroc phases.

\begin{tabular}{|c|c|c|c|c|c|c|c|c|c|c|c|c|}
\hline \multirow[t]{2}{*}{ Ions } & \multicolumn{2}{|c|}{ Hollandite } & \multicolumn{2}{|c|}{ Zirconolite } & \multicolumn{2}{|c|}{ Perovskite } & \multicolumn{3}{|c|}{ Rutile } & \multicolumn{2}{|c|}{ Molybdate } & \multirow{2}{*}{$\begin{array}{c}\text { Hibonite } \\
\text { RM }\end{array}$} \\
\hline & $\mathbf{A M}$ & $\mathbf{R M}$ & $\mathbf{A M}$ & $\mathbf{R M}$ & $\mathbf{A M}$ & $\mathbf{R M}$ & $\mathbf{A P}$ & $\mathbf{A M}$ & $\mathbf{R M}$ & $\mathbf{A M}$ & $\mathbf{R M}$ & \\
\hline $\mathrm{Na}^{+}$ & 0.01 & - & - & 0.02 & - & 0.02 & - & - & - & - & - & 0.12 \\
\hline $\mathrm{Cs}^{+}$ & 0.02 & 0.04 & - & - & - & - & - & - & - & 0.01 & - & 0.01 \\
\hline $\mathrm{Ca}^{2+}$ & 0.04 & 0.01 & 0.77 & 0.84 & 0.77 & 0.78 & - & - & - & 0.54 & 0.71 & 0.42 \\
\hline $\mathrm{Sr}^{2+}$ & - & 0.03 & - & - & 0.01 & 0.02 & - & - & - & - & 0.12 & - \\
\hline $\mathbf{B a}^{2+}$ & 1.07 & 1.00 & 0.01 & - & - & - & - & - & - & 0.27 & 0.02 & - \\
\hline $\mathrm{Mg}^{2+}$ & 0.02 & - & 0.01 & - & 0.01 & 0.01 & - & - & - & - & - & - \\
\hline $\mathrm{Fe}^{2+}$ & 0.23 & 0.17 & 0.05 & 0.02 & - & - & - & - & - & 0.01 & - & 0.29 \\
\hline $\mathrm{Ni}^{2+}$ & 0.04 & 0.08 & - & - & - & - & - & - & - & - & - & 0.15 \\
\hline $\mathrm{Co}^{2+}$ & 0.01 & 0.07 & - & - & - & - & - & - & - & - & - & 0.27 \\
\hline $\mathrm{Al}^{3+}$ & 1.68 & 1.83 & 0.23 & 0.17 & 0.04 & 0.02 & 0.01 & 0.01 & - & 0.04 & - & 8.47 \\
\hline $\mathrm{La}^{3+}$ & - & 0.01 & 0.01 & - & 0.04 & 0.04 & - & - & - & - & - & - \\
\hline $\mathrm{Ce}^{3+}$ & 0.06 & 0.06 & 0.04 & 0.02 & 0.07 & 0.03 & - & - & - & - & - & - \\
\hline $\mathbf{G d}^{3+}$ & 0.01 & 0.00 & 0.01 & 0.04 & 0.01 & 0.02 & - & - & - & - & - & - \\
\hline $\mathrm{Si}^{4^{+}}$ & 0.01 & - & - & - & - & - & - & - & - & 0.02 & - & 0.01 \\
\hline $\mathrm{Ti}^{4^{++}}$ & 5.94 & 5.89 & 2.06 & 2.04 & 0.98 & 1.00 & 0.94 & 0.94 & 0.98 & 0.11 & 0.01 & 2.54 \\
\hline $\mathbf{Z r}^{4+}$ & 0.02 & - & 0.81 & 0.84 & - & - & 0.05 & 0.05 & 0.02 & - & - & - \\
\hline $\mathrm{Mo}^{6+}$ & - & - & - & - & - & - & - & - & - & 0.62 & 0.71 & - \\
\hline Total & 9.16 & 9.18 & 3.99 & 4.01 & 1.94 & 1.95 & 1.00 & 1.00 & 1.00 & 1.62 & 1.57 & 12.28 \\
\hline $\mathrm{O}^{2-}$ & 16.00 & 16.00 & 7.00 & 7.00 & 3.00 & 3.00 & 2.00 & 2.00 & 2.00 & 3.00 & 3.00 & 19.00 \\
\hline
\end{tabular}




\section{STEP 2}

THE PURPOSE: Development of Synroc formulation to immobilize one of the PA "Mayak" HLW compositions.

This work was also performed in cooperation with ANSTO and IGEM.

\section{Major phases:}

zirconolite,

hollandite,

rutile;

perovskite.

\section{Minor phases:}

zirconia,

celsian,

X-phase $\left(\mathrm{Ca}_{2.65} \mathrm{U}_{0.3} \mathrm{Ce}_{0.2}\right)\left(\mathrm{Ti}_{7.3} \mathrm{Min}_{0.6} \mathrm{Zr}_{0.4} \mathrm{Al}_{0.3}\right) \mathrm{O}_{20} \quad$ (murataite or uhligite $\mathrm{Ca}_{3}\left(\mathrm{Ti}_{5.55} \mathrm{Al}_{1.8} \mathrm{Zr}_{1.6}\right) \mathrm{O}_{20}$ ) or (in wt\%): $59.8 \mathrm{TiO}_{2} ; 15.6 \mathrm{CaO} ; 7.0 \mathrm{UO}_{2} ; 5.6 \mathrm{ZrO}_{2} ; 4.7$ $\mathrm{MnO} ; 4.1 \mathrm{Ce}_{2} \mathrm{O}_{3} ; 1.8 \mathrm{Al}_{2} \mathrm{O}_{3}$

Chemical composition of different zones in X-phase crystal.

\begin{tabular}{|c|c|c|c|c|}
\hline Oxides & 1 (core) & 2 & 3 & 4 (rim) \\
\hline $\mathrm{Al}_{2} \mathrm{O}_{3}$ & 0.8 & 1.6 & 3.7 & 2.8 \\
\hline $\mathrm{SiO}_{2}$ & 0.2 & 0.5 & 0.2 & 0.3 \\
\hline $\mathrm{K}_{2} \mathrm{O}$ & 0.1 & 0.3 & 0.7 & 0.1 \\
\hline $\mathrm{CaO}$ & 15.6 & 16.5 & 13.0 & 15.9 \\
\hline $\mathrm{TiO}_{2}$ & 54.8 & 56.5 & 6.9 & 65.9 \\
\hline $\mathrm{Cr}_{2} \mathrm{O}_{3}$ & 0.3 & - & 0.2 & - \\
\hline $\mathrm{MnO}$ & 3.6 & 4.1 & 5.7 & 5.6 \\
\hline $\mathrm{FeO}$ & 0.2 & - & 0.1 & - \\
\hline $\mathrm{NiO}$ & 0.2 & - & - & 0.2 \\
\hline $\mathrm{ZrO} 2$ & 5.7 & 6.0 & 3.8 & 4.3 \\
\hline $\mathrm{BaO}_{\mathrm{Ce}} \mathrm{O}_{3}$ & - & 3.4 & 3.7 & - \\
\hline $\mathrm{UO}_{2}$ & 6.0 & 2.9 & 2.7 & 3.7 \\
\hline $\mathrm{Total}$ & 11.9 & 7.0 & 2.0 & 0.8 \\
\hline
\end{tabular}




\section{RESULTS AND DISCUSSION}

\section{SYNROC-LIKE CERAMIC}

$\mathrm{XRD}$ and SEM study of the Synroc-like material has shown that it consists of crystalline phases and small quantity of residual glass. Four of the phases identified -

- zirconolite,

- hollandite,

- rutile and

- perovskite

are typical of analogous phases from the other Synroc formulations produced by both hot-pressing and melting.

The main peculiarity of the synthetic minerals is a more complicated composition due to occurrence of some additional elements.

Perovskite is enriched with $\mathrm{MnO}$ (up to $2.6 \%$ ),

hollandite is also enriched with $\mathrm{MnO}(1.6 \%)$ as well as $\mathrm{K}_{2} \mathrm{O}(4.3 \%)$,

zirconolite has elevated $\mathrm{Cr}_{2} \mathrm{O}_{3}(1.1 \%), \mathrm{MnO}(1.1 \%)$, and $\mathrm{UO}_{2}(1.0 \%)$ contents.

Glass is present in the sample as a minor constituent. Its content is about 5 vol.\%. It is located in inter-grain space of crystalline phases and mainly composed of silica, alumina, titania, alkalis, alkaline earths and manganese oxides. 
Compositions (in wt\%) of the phases in the sample determined by SEM/EMPA.

\begin{tabular}{|l|c|c|c|c|c|c|c|c|c|}
\hline Oxide & Bulk & $\begin{array}{l}\text { Zirco- } \\
\text { nolite }\end{array}$ & $\begin{array}{l}\text {-dilan } \\
\text {-dite }\end{array}$ & Rutile & $\begin{array}{l}\text { Perov } \\
\text { skite }\end{array}$ & $\begin{array}{l}\mathrm{X} \text { - } \\
\text { phase }\end{array}$ & Glass & $\begin{array}{l}\text { Zirco- } \\
\text { nia }\end{array}$ & Celsian \\
\hline $\mathrm{Na}_{2} \mathrm{O}$ & 0.7 & - & 0.6 & - & - & 0.1 & 4.3 & - & 1.1 \\
\hline $\mathrm{Al}_{2} \mathrm{O}_{3}$ & 4.3 & 1.8 & 7.2 & 0.2 & 0.4 & 1.8 & 20.3 & 0.6 & 18.5 \\
\hline $\mathrm{SiO}_{2}$ & 1.8 & 0.1 & 0.2 & 0.1 & 0.1 & 0.3 & 37.1 & 0.2 & 29.0 \\
\hline $\mathrm{K}_{2} \mathrm{O}$ & 1.9 & 0.1 & 4.3 & 0.1 & - & 0.1 & 7.8 & - & 3.7 \\
\hline $\mathrm{CaO}$ & 7.5 & 12.6 & 0.3 & 0.4 & 33.5 & 15.6 & 6.5 & 4.5 & 6.2 \\
\hline $\mathrm{TiO}_{2}$ & 55.4 & 45.9 & 66.9 & 93.4 & 57.4 & 59.8 & 11.1 & 22.6 & 13.2 \\
\hline $\mathrm{Cr}_{2} \mathrm{O}_{3}$ & 0.6 & 1.1 & 0.2 & - & 0.1 & 0.1 & - & 0.8 & 0.1 \\
\hline $\mathrm{MnO}^{2}$ & 2.0 & 1.1 & 1.6 & - & 2.6 & 4.7 & 4.9 & 0.4 & 1.3 \\
\hline $\mathrm{FeO}^{2}$ & 0.2 & 0.1 & 0.1 & - & - & 0.1 & 0.2 & - & 0.2 \\
\hline $\mathrm{NiO}^{2}$ & 0.9 & 0.5 & 2.1 & - & - & 0.1 & - & 0.2 & 0.3 \\
\hline $\mathrm{ZrO}_{2}$ & 15.8 & 34.4 & 0.5 & 5.6 & 0.2 & 5.6 & 0.4 & 69.4 & 0.2 \\
\hline $\mathrm{BaO}^{2}$ & 7.4 & - & 15.9 & - & 1.7 & 0.6 & 7.3 & - & 26.2 \\
\hline $\mathrm{Ce}_{2} \mathrm{O}_{3}$ & 0.5 & 1.3 & - & - & 3.8 & 4.1 & 0.1 & 0.8 & - \\
\hline $\mathrm{UO}_{2}$ & 1.0 & 1.0 & 0.1 & 0.2 & 0.1 & 7.0 & 0.2 & 0.5 & - \\
\hline
\end{tabular}

Element distribution in the sample (fraction of total, \%).

\begin{tabular}{|l|c|c|c|c|c|c|c|c|c|c|c|c|c|c|}
\hline Phase & $\mathrm{Na}$ & $\mathrm{Al}$ & $\mathrm{Si}$ & $\mathrm{K}$ & $\mathrm{Ca}$ & $\mathrm{Ti}$ & $\mathrm{Cr}$ & $\mathrm{Mn}$ & $\mathrm{Fe}$ & $\mathrm{Ni}$ & $\mathrm{Zr}$ & $\mathrm{Ba}$ & $\mathrm{Ce}$ & $\mathrm{U}$ \\
\hline Zirconolite & - & 18 & 2 & 1 & 65 & 38 & 89 & 30 & 55 & 21 & 94 & $<1$ & 58 & 52 \\
\hline Hollandite & 47 & 56 & 4 & 78 & 1 & 43 & 9 & 33 & 33 & 78 & 1 & 92 & 1 & 4 \\
\hline Rutile & - & $<1$ & $<1$ & $<1$ & $<1$ & 8 & - & $<1$ & - & - & 2 & - & - & 1 \\
\hline Perovskite & - & $<1$ & $<1$ & $<1$ & 20 & 5 & 1 & 8 & - & - & $<1$ & 1 & 19 & 1 \\
\hline X-phase & 1 & 2 & 1 & $<1$ & 9 & 5 & $<1$ & 14 & 5 & 1 & 2 & $<1$ & 21 & 41 \\
\hline Glass & 52 & 23 & 92 & 20 & 4 & 1 & - & 15 & 7 & - & $<1$ & 6 & 1 & 1 \\
\hline
\end{tabular}




\section{Step 3}

MELTED ZIRCONOLITE/PYROCHLORE-RICH CERAMICS

BULK COMPOSITION OF THE SAMPLES (WT\%)

\begin{tabular}{|c|c|c|c|c|c|c|}
\hline Oxides & $\mathrm{Z}-1$ & $\mathrm{Z}-2$ & $\mathrm{Z}-3$ & $\mathrm{Z}-4$ & $\mathrm{Z}-5$ & Synroc-F \\
\hline $\mathrm{Na}_{2} \mathrm{O}$ & 0.2 & 0.2 & 0.2 & 0.2 & - & - \\
\hline $\mathrm{Al}_{2} \mathrm{O}_{3}$ & 7.5 & 8.0 & 10.8 & 2.1 & 2.6 & 0.8 \\
\hline $\mathrm{SiO}_{2}$ & 5.8 & 6.5 & 5.5 & 1.8 & - & - \\
\hline $\mathrm{CaO}$ & 5.1 & 5.6 & 6.3 & 13.7 & 10.0 & 9.3 \\
\hline $\mathrm{BaO}$ & - & - & - & - & 2.4 & 1.0 \\
\hline $\mathrm{TiO}_{2}$ & 25.2 & 30.9 & 40.6 & 36.3 & 48.4 & 40.0 \\
\hline $\mathrm{FeO}^{2}$ & 0.2 & 0.2 & 0.2 & 0.1 & - & - \\
\hline $\mathrm{ZrO}_{2}$ & 24.0 & 21.0 & 29.2 & 37.6 & 19.6 & 1.6 \\
\hline $\mathrm{Gd}_{2} \mathrm{O}_{3}$ & 30.0 & 28.1 & 7.3 & 7.6 & 6.6 & - \\
\hline $\mathrm{UO}_{2}$ & - & - & - & - & 10.4 & 47.0 \\
\hline $\mathrm{Total}^{2}$ & 98.0 & 100.5 & 100.1 & 99.4 & 100.0 & 99.7 \\
\hline
\end{tabular}

n.a. - not analyzed. Z-1, ... Z-5 - sample numbers.

\section{EMPA data for Z1-Z4 samples}

Zirconolite-1:

Zirconolite-2:

Zirconia (Baddeleyite)

Rutile

Glass
$\mathrm{Ca}_{0.35} \mathrm{Gd}_{0.72} \mathrm{Zr}_{1.03} \mathrm{Ti}_{1.42} \mathrm{Al}_{0.45} \mathrm{O}_{7.00}$

$\mathrm{Ca}_{0.31} \mathrm{Gd}_{0.71} \mathrm{Zr}_{0.32} \mathrm{Ti}_{2.02} \mathrm{Al}_{0.59} \mathrm{Si}_{0.02} \mathrm{Fe}_{0.01} \mathrm{O}_{7.00}$

$\mathrm{Ca}_{0.04} \mathrm{Gd}_{0.19} \mathrm{Zr}_{0.72} \mathrm{Ti}_{0.11} \mathrm{Al}_{0.01} \mathrm{O}_{2.00}$

$\mathrm{Gd}_{0.01} \mathrm{Zr}_{0.03} \mathrm{Ti}_{0.95} \mathrm{Al}_{0.01} \mathrm{Si}_{0.01} \mathrm{O}_{2.00}$

$\mathrm{Na}_{0.12} \mathrm{Ca}_{0.75} \mathrm{Gd}_{0.20} \mathrm{Ti}_{0.30} \mathrm{Al}_{1.42} \mathrm{Si}_{2.06} \mathrm{Fe}_{0.01} \mathrm{O}_{8.00}$ 


\section{MATERIALS FOR PLUTONIUM IMMOBILIZATION}

Promising host phases for Pu immobilization: zirconolite and pyrochlore.

Monoclinic zirconolite structure transforms into cubic pyrochlore structure when $\mathrm{Pu}^{3+}$ content exceeds 0.4 formula units in the $\mathrm{Ca}$ site and $\mathrm{Pu}^{4+}$ content exceeds 0.15 formula units in the $\mathrm{Zr}$ site. ${ }^{2}$ The latter case corresponds to $\sim 11$ $w+\%{ }^{239} \mathrm{PuO}_{2}$.

We synthesized zirconolite-rich ceramics containing $\mathrm{U}^{4+}\left(\mathrm{Pu}^{4+}\right.$ analog) and $\mathrm{Gd}^{3+}\left(\mathrm{Pu}^{3+}\right.$ and $\mathrm{Cm}^{3+}$ analog) by means of both the cold crucible inductive melting and cold pressing+sintering. Up to $50 \mathrm{wt} \% \mathrm{UO}_{2}$ (Synroc-F formulation) or 30 wt\% $\mathbf{G d}_{2} \mathrm{O}_{3}$ were incorporated in synthetic zirconolite/pyrochlore.

\section{Another hosts suggested:}

- Murataite/uhligite,

- zircon,

- cubic zirconia,

- sphene (titanite),

- aechynite/euxenite (REE,Th,U,Ca) $\left(\mathrm{Ti}, \mathrm{Nb}, \mathrm{Ta}, \mathrm{Fe}^{3+}\right)_{2} \mathrm{O}_{6}$, brannerite $\mathrm{UTi}_{2} \mathrm{O}_{6}$,

- monazite,

- apatite and related phases (silicophosphates),

- NZP ceramics and analogs,

- borosilicate glass,

- phosphate glass.

\footnotetext{
${ }^{2}$ E.R. VANCE, A. JOSTSONS, R.A. DAY, C.J. BALL, B.D. BEGG, P.J. ANGEL, Mat. Res. Soc. Symp. Proc. 412 (1996) $41-47$. 
Table Il. The cold crucible melting process parameters and properties of the materials.

\begin{tabular}{|c|c|c|c|c|c|c|c|c|c|c|c|}
\hline \multirow[b]{2}{*}{ Parameters } & \multicolumn{11}{|c|}{ Materials } \\
\hline & $\begin{array}{l}\text { Boro- } \\
\text { silicate } \\
\text { glasses }\end{array}$ & $\begin{array}{l}\text { Pyroxene- } \\
\text { based }\end{array}$ & $\begin{array}{l}\text { Melted } \\
\text { mixed } \\
\text { solid } \\
\text { waste }\end{array}$ & \multicolumn{2}{|c|}{$\begin{array}{l}\text { Sphene- } \\
\text { based }\end{array}$} & $\begin{array}{l}\text { Silico- } \\
\text { phosphate- } \\
\text { containing } \\
\text { (melted } \\
\text { incinerator } \\
\text { ash) } \\
\end{array}$ & Synroc-A & Synroc-C & $\begin{array}{l}\text { Synroc- } \\
\text { C with } \\
\text { PA } \\
\text { Mayak } \\
\text { HLW }\end{array}$ & Synroc-F & $\begin{array}{l}\text { Zircono- } \\
\text { lite-rich }\end{array}$ \\
\hline Operating frequency, $\mathrm{MHz}$ & 1.76 & 1.76 & 1.76 & 5.28 & 5.28 & 1.76 & 1.76 & 1.76 & 1.76 & 1.76 & 1.76 \\
\hline Vibrating power, $\mathrm{kW}$ & 60,160 & 60 & 60 & 63 & 63 & 60,160 & 60 & 60 & 60 & 160 & 60 \\
\hline Process temperatures, ${ }^{\circ} \mathrm{C}$ & $1200-1300$ & $1300-1400$ & $1500 \cdot 1700$ & \multicolumn{2}{|c|}{$1800-1900$} & $1300-1600$ & $1350-1400$ & $1400-1600$ & $\sim 1600$ & $1500-1700$ & $1650-1900$ \\
\hline Crucible inside diameter, $\mathrm{mm}$ & 440 & 110 & 100 & 88 & 160 & $250-500$ & 60 & 110 & 100 & 73 & 100 \\
\hline Melt productivity, $\mathrm{kg} / \mathrm{h}$ & $\leq 25$ & $10-12$ & $\sim 8$ & 2.0 & 4.6 & $10-20$ & $10-12$ & 6.7 & 5.4 & $\sim 10$ & 6.0 \\
\hline $\begin{array}{l}\text { Specific melt productivity, } \\
\mathrm{kg} /\left(\mathrm{h} \mathrm{dm}^{2}\right)\end{array}$ & $\leq 1.67$ & $9.5-12.5$ & $\sim 10$ & 3.3 & 2.3 & $1-2$ & $2.0-2.4$ & 7.1 & 6.9 & $\sim 24$ & 7.6 \\
\hline Melting ratio, $\mathrm{kW} \mathrm{h/kg}$ & $5-7$ & $5-7$ & $\sim 7$ & 20.5 & 4.8 & 6.8 & $5-6$ & 2.3 & 5.2 & $4-6$ & 4.0 \\
\hline Cs loss, $\%$ & $3-6$ & $5-8$ & $5-10$ & $\sim 10$ & $4-7$ & $3-7$ & $3-6$ & $5-8$ & $5-8$ & - & - \\
\hline$\sum$ alpha-emitters loss, $\%$ & $<0.1$ & -0.1 & $<1$ & 0.1 & 0.1 & $<0.1$ & $<0.1$ & $<0.1$ & $<0.1$ & $<0.5$ & $\sim 0.1$ \\
\hline Cs leach rate, $\mathrm{g} /\left(\mathrm{m}^{2} \text { day }\right)^{1}$ & $10^{-1}-10^{-2}$ & $\sim 10^{-2}$ & $\sim 10^{-2}$ & \multicolumn{2}{|c|}{$\sim 10^{-2}$} & $10^{-2}-10^{-3}$ & $\sim 10^{-2}$ & $10^{-1}-10^{-2}$ & n.m. & n.m. & n.m. \\
\hline Sr leach rate, $g /\left(\mathrm{m}^{2} \text { day }\right)^{T}$ & $10^{-2}-10^{-3}$ & $\sim 10^{-3}$ & $\sim 10^{-3}$ & \multicolumn{2}{|c|}{$\sim 10^{-3}-10^{-4}$} & $10^{-3}-10^{-4}$ & $\sim 10^{-3}$ & $10^{-1}-10^{-3}$ & n.m. & n.m. & n.m. \\
\hline Mo leach rate, $g /\left(\mathrm{m}^{2} \text { day }\right)^{1}$ & n.m. & n.m. & n.m. & \multicolumn{2}{|c|}{ n.m. } & n.m. & n.m. & $10^{0}-10^{-2}$ & n.m. & n.m. & n.m. \\
\hline $\mathrm{U}(\mathrm{Pu})$ leach rate, $\mathrm{g} /\left(\mathrm{m}^{2} \text { day }\right)^{1}$ & $10^{-3} \cdot 10^{-4}$ & $10^{-3}-10^{-4}$ & $\sim 10^{-4}$ & $10^{-4}$ & $10^{-4}$ & $\sim 10^{-5}$ & $10^{-3}-10^{-4}$ & n.m. & n.m. & $\sim 10^{-5}-10^{-6}$ & $<10^{-6}$ \\
\hline Density, $\mathrm{g} / \mathrm{cm}^{3}$ & $2.5-2.6$ & $2.5-2.6$ & $2.6-2.9$ & -3 & $\sim 3$ & $2.7-3.0$ & 2.9 & $4.3-4.6^{2}$ & $4.5-4.7^{2}$ & n.m. & n.m. \\
\hline
\end{tabular}

${ }^{1} \mathrm{MCC}-1,95^{\circ} \mathrm{C} ;{ }^{2}$ product density is varied over the solidified block; n.m. - not measured 


\section{CONCLUSION}

Both glasses and ceramics may be used to immobilize institutional and NPP liquid wastes.

Incorporation of up to $40-45 \mathrm{wt}$ \% of waste oxides in borosilicate, aluminosilicate, and aluminophosphate glasses has been demonstrated using lab- and benchscale facilities.

The most promising melter is the cold crucible, but Joule heated ceramic melter can be also applied for glasses with relatively low melting temperatures.

Aluminophosphate glasses as well as alkali aluminosilicate ceramics are suitable for immobilization of wastes with high sulfate and chloride content. 


\title{
From the Cold Crucible Melter
}

to

\section{the Advanced Cold Crucible Melter}

\section{Principle, operation, design, applications}

\author{
Antoine JOUAN \\ Commissariat à l'Énergie Atomique \\ MARCOULE
}




\section{The PRINCIPLE}

\section{An idea and a patent about 70 years old !}
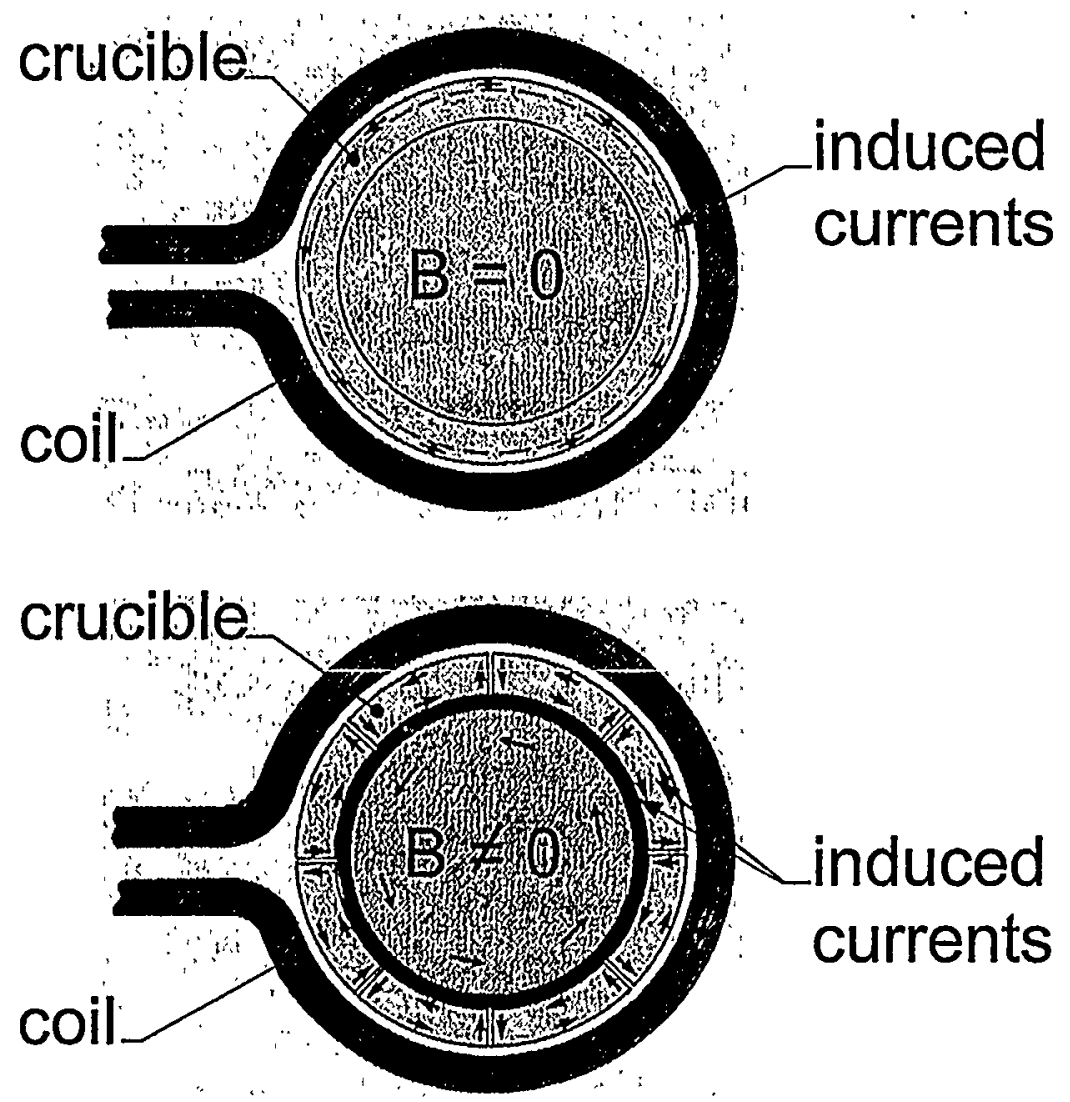

The segmentation of the water cooled crucible (blue) opens the Faraday cage and allows the electric field to enter ...... and to heat by JOULE effect 


\section{PHYSICAL LAW and APPLICABLE DOMAINS}

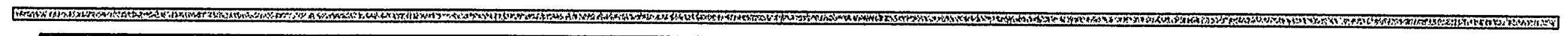

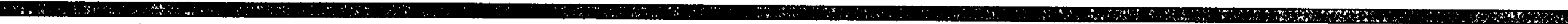

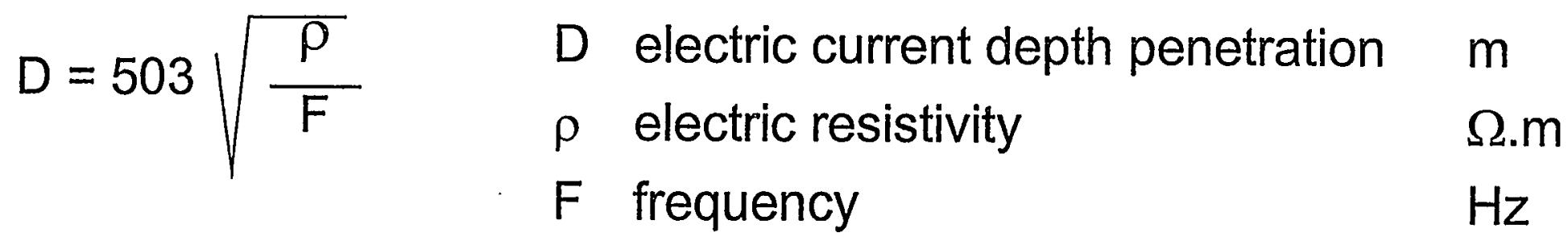
Si $F=310^{3}$
Si $F=310^{5}$
Si $F=310^{6}$
$D=1 \mathrm{~cm}$
$D=0,2 m$
$D=2 \mathrm{~cm}$

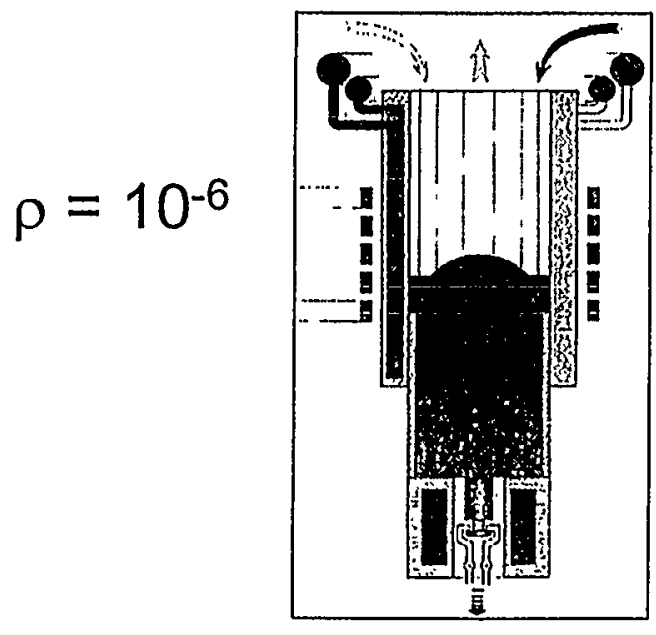

$\varnothing 0.1$ to $0.2 \mathrm{~m}$

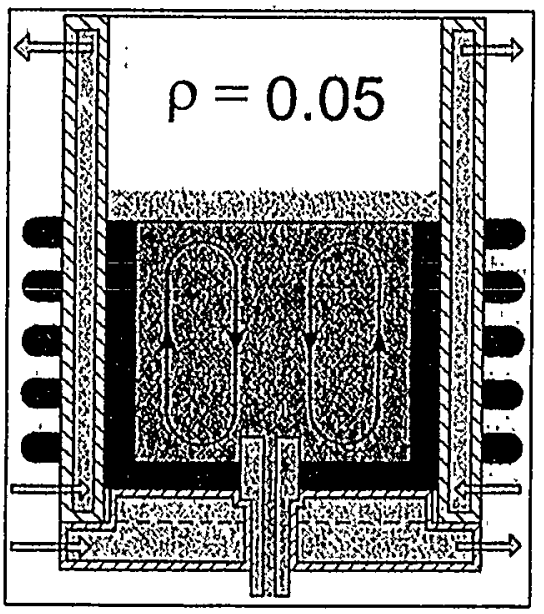

$\varnothing 0.5$ to $1 \mathrm{~m}$

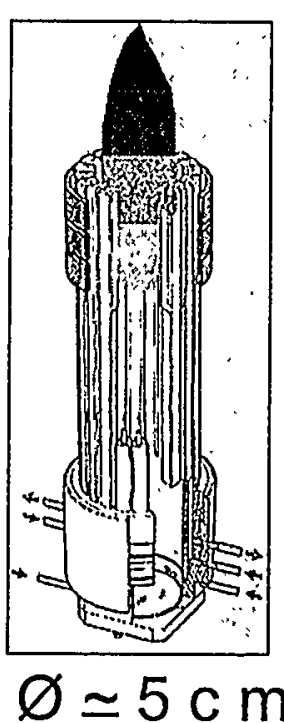

$\rho=0.005$

Augusta GA - May 4-6, 1999 


\section{C@ ADVANTAGES of a GLASS CCM}

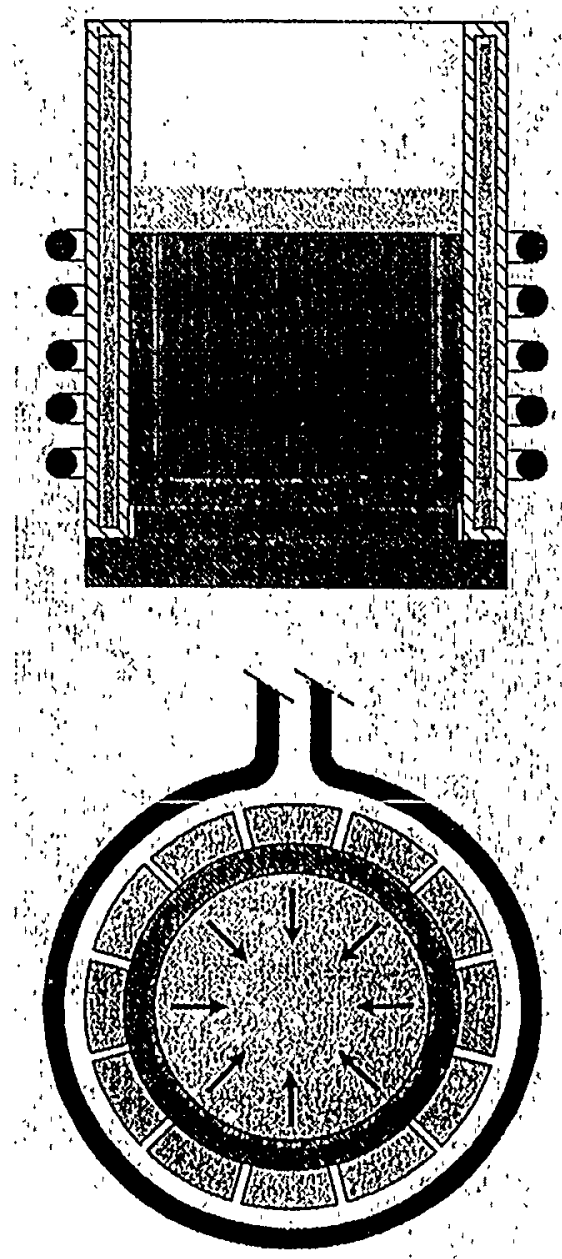

Workshop on Improved Design and Performance of HLW Melters
- The glass (or molten oxides blend) is heated by JOULE effect

- The power is generated directly in the molten product

- The molten product is located in its own water-cooled skull

- corrosion and wear are limited

- no pollution of the product

- high temperature is feasible

$-\mathrm{UO}_{2}$

$2500^{\circ} \mathrm{C}$

- Synroc $1500^{\circ} \mathrm{C}$

- Zirconolite ceramic $1800{ }^{\circ} \mathrm{C}$

It increases flexibility in the choice of glass composition 


\section{ADVANTAGES of a GLASS CCM (cont' d)}

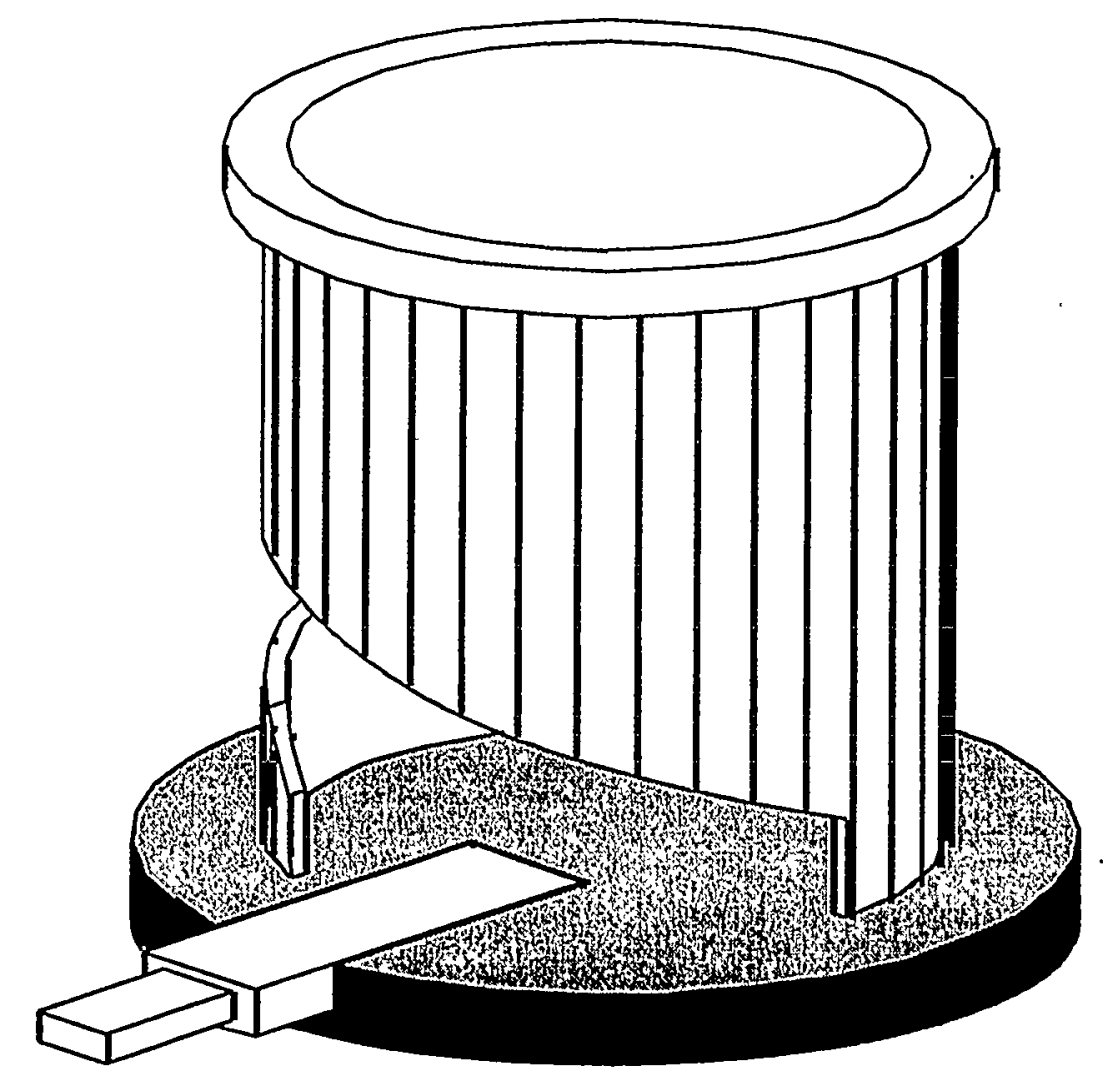

The possibility to use

a water cooled pouring valve

- it is like a tap

- possibility to open, to close and to control the molten glass flowrate

- its reliability has been demonstrated

- it is replacable : an insert in a water cooled structure 


\section{ADVANTAGES of a GLASS CCM (cont" d)}

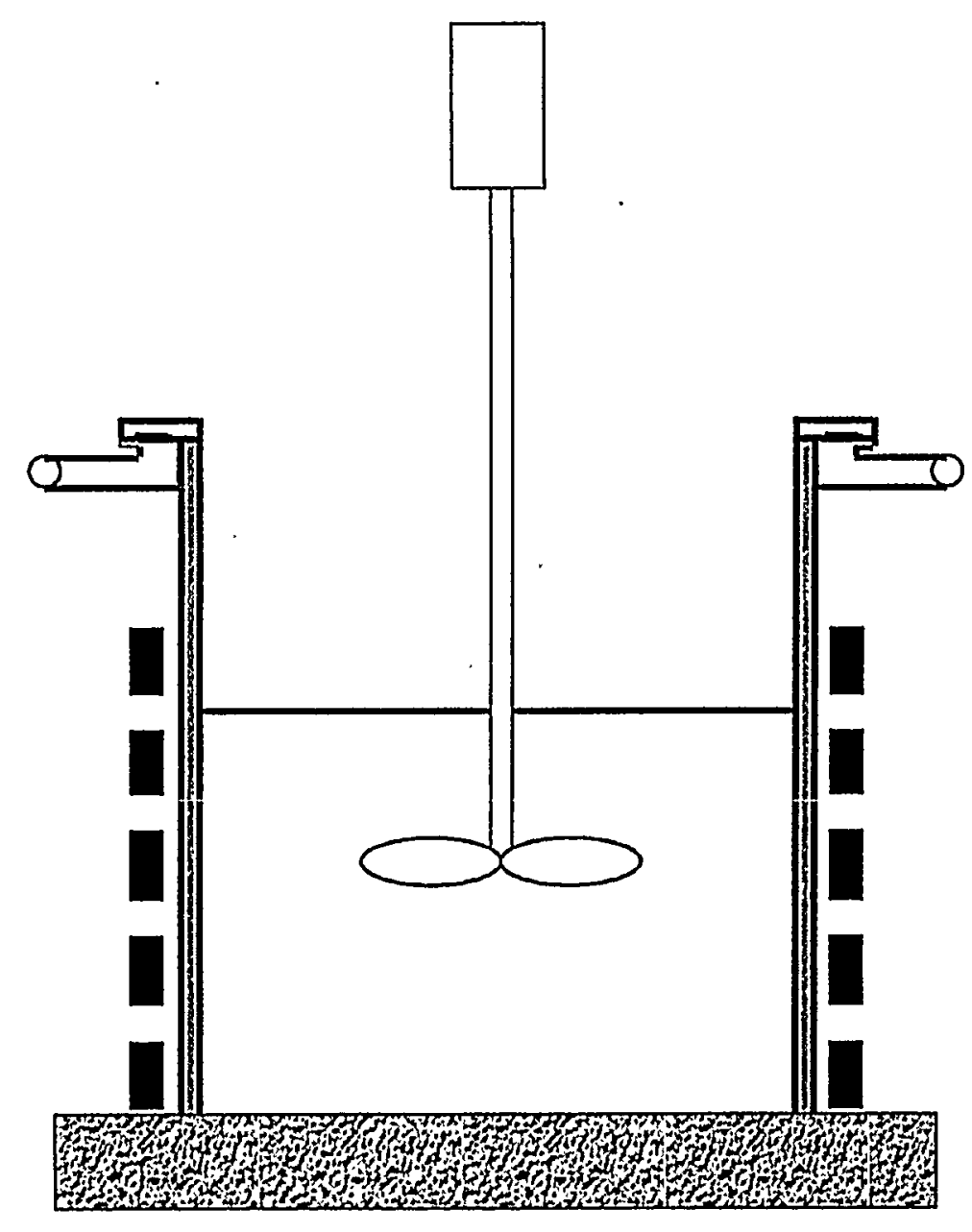

The possibility to stir the molten glass with a water-cooled mechanical stirrer retractable in case of power interruption

- allows higher throughput

- allows a good homogeneity

- of temperature

- of composition

- prevents particules settling (cristals, noble metals ...) 


\section{ADVANTAGES of a GLASS CCM (cont' d)}

As secondary waste

Three independant parts are to be considered

- the segmented cylinder (stainless steel)

- the coil (copper)

- the slab (stainless steel and concrete)

It can be a low level waste, easy to decontaminate and to store taking into account that :

The cold glass (skull) doesn't stick to the cold walls 


\section{HOW to START a GLASS CCM?}

Cold glass is an isolating material

It must be preheated!

- burners

- microwaves have been tested

-etc ...

- exothermic metal oxidation is the most simple mean using a metalilic ring, $\quad \mathrm{Ti} \quad \mathrm{Zr}$

$$
\mathrm{M}+\mathrm{O}_{2} \rightarrow \mathrm{MO}_{2}+\text { heat }
$$

which make the glass melt

.... and induction can occur ! 


\section{COLD CRUCIBLE YIELD glass melting}

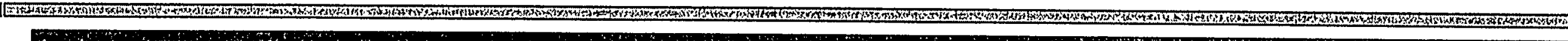

- electrical losses in the coil

- electrical losses in the cold crucible $\quad 20 \%$

- power supplied to the glass itself

- in the coil

- in the cold crucible

- in the cold crucible

- used to melt

$10 \%$

$20 \%$ (electrical losses)

$40 \%$ (thermic transfer)
$10 \%$

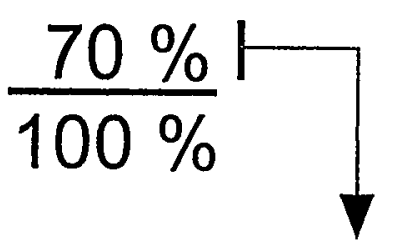

used to melt 30 to $40 \%$ thermal losses 60 to $70 \%$

$\frac{30 \%}{100 \%}$

Glass melting in a conventional refractory furnace

$1 \mathrm{kWh} / \mathrm{kg}$ of glass

Glass melting in a cold crucible

$1.5 \mathrm{kWh} / \mathrm{kg}$ of glass 


\section{COLD CRUCIBLE YIELD metal melting}

- electrical losses in the coil

- electrical losses in the cold crucible

- power supplied to the metal itself

- in the coil

- in the cold crucible

- in the cold crucible

- used to melt
$25 \%$

$35 \%$

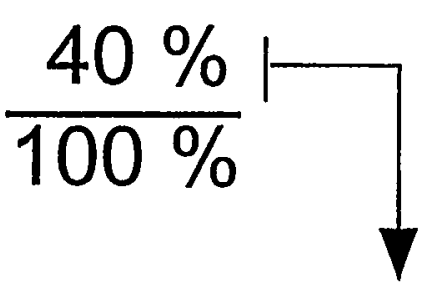

used to melt $25 \%$ thermal losses $75 \%$ 


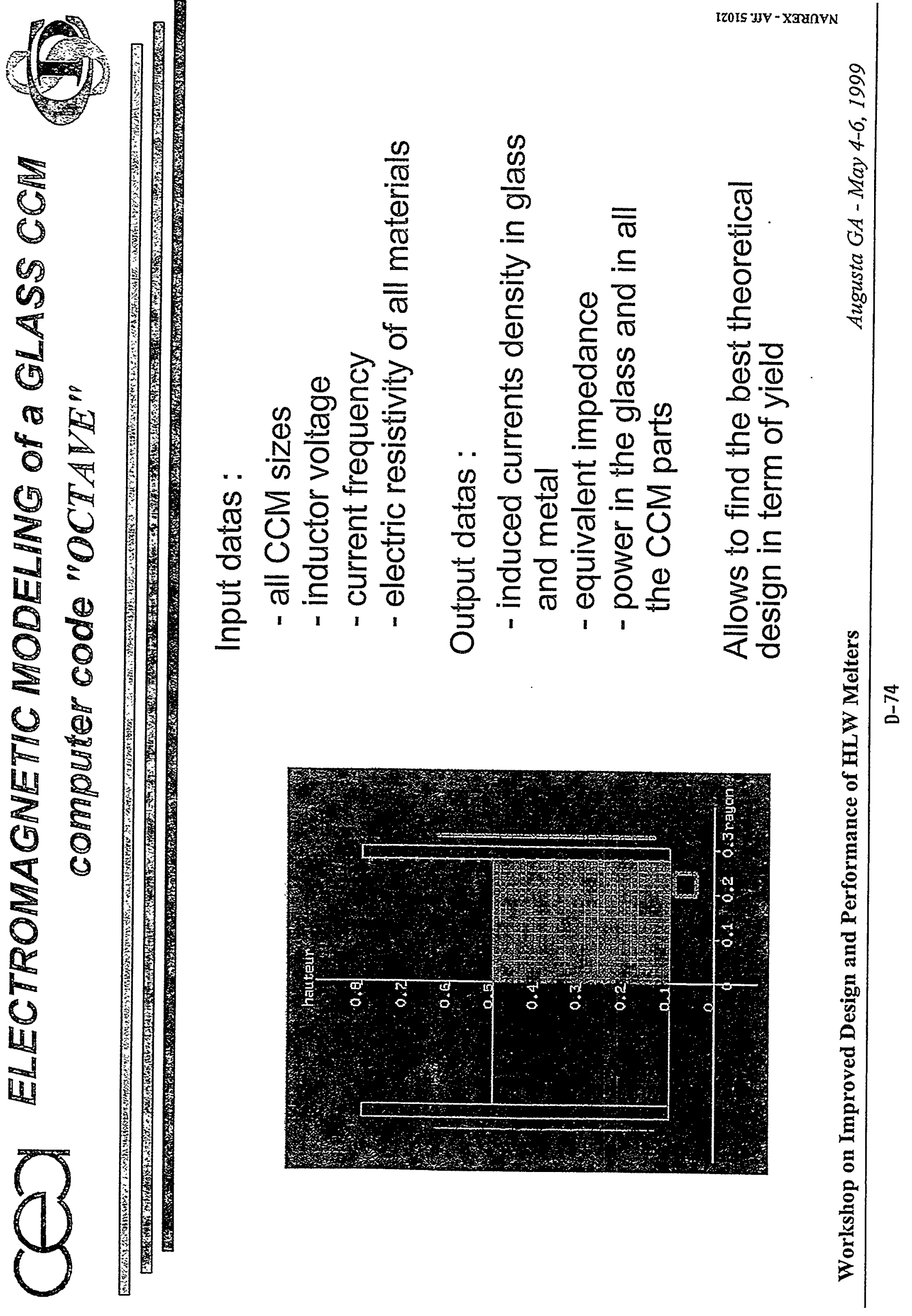




\section{ELECTRO MAGNETO THERMAL MODELING of a GLASS CCM}

Based on electrical parameters and rheological properties: electric and thermal conductivity, viscosity, expansion cœefficient A computer code is used to localize the distribution of :

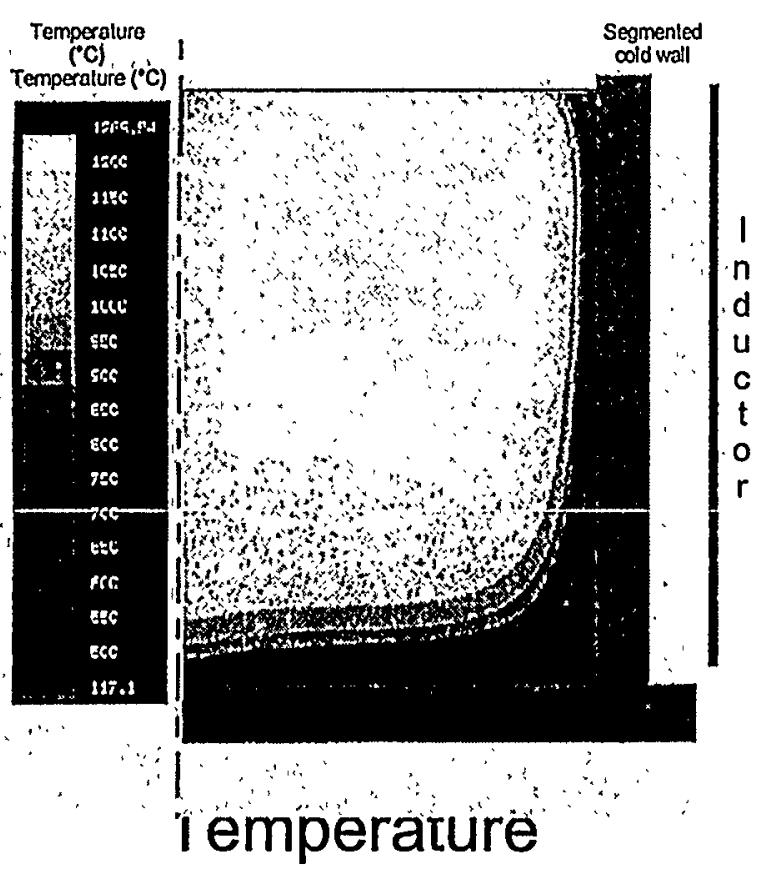

Workshop on Improved Design and Performance of HLW Melters

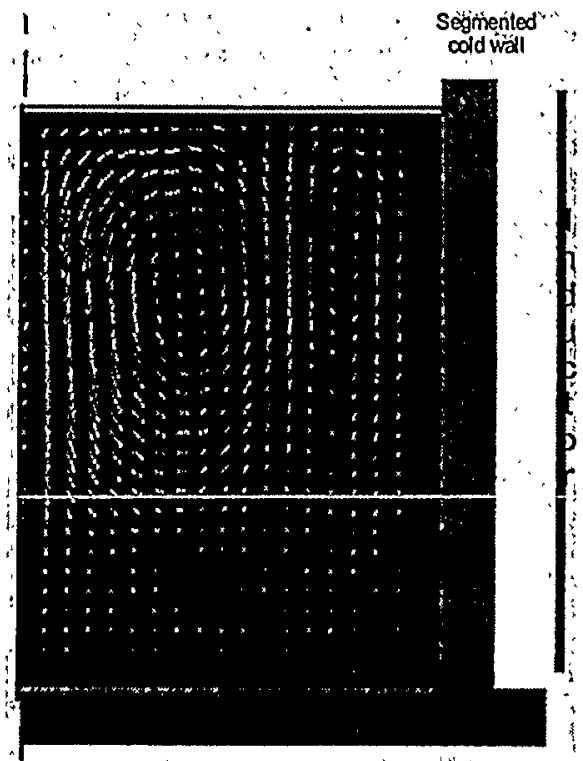

Thermal convection currents and velocity 


\section{CO COLD CRUCIBLE GLASS MELTING THROUGHPUT}

- Proportional to the surface area

$\mathrm{D}^{2}$

- Proportional to the fourth power of the temperature $\mathrm{T}^{4}$

\begin{tabular}{|l|c|c|c|}
\hline Diameter $\mathrm{cm}$ & 55 & 100 & 120 \\
\hline Temperature $1200^{\circ} \mathrm{C}$ & 30 & 100 & 140 \\
\hline Temperature $1350^{\circ} \mathrm{C}$ & 50 & 160 & 230 \\
\hline
\end{tabular}

- Maximized by stirring

all values in $\mathrm{kg} \mathrm{h-1}$ 


\section{COLD CRUCIBLE GLASS MELTING THROUGHPUT}

- Proportional to the surface area $D^{2}$

- Proportional to the fourth power of the temperature $-\mathrm{T}^{4}$

\begin{tabular}{|c|c|c|c|c|c|}
\hline & $\begin{array}{l}\text { CCM } \\
\varnothing \mathrm{cm}\end{array}$ & 55 & 100 & 120 & 150 \\
\hline $\begin{array}{l}\text { solid } \\
\text { feed } \\
k g h^{-1}\end{array}$ & $\begin{array}{l}1200^{\circ} \mathrm{C} \\
1350^{\circ} \mathrm{C}\end{array}$ & $\begin{array}{l}30 \\
50\end{array}$ & $\begin{array}{l}100 \\
160\end{array}$ & $\begin{array}{r}140 \\
230\end{array}$ & $\begin{array}{l}220 \\
360\end{array}$ \\
\hline $\begin{array}{c}\text { liquid } \\
\text { feed } \\
/ h^{-1}\end{array}$ & $\begin{array}{l}1200^{\circ} \mathrm{C} \\
1350^{\circ} \mathrm{C}\end{array}$ & $\begin{array}{l}15 \\
25\end{array}$ & $\begin{array}{l}50 \\
80\end{array}$ & $\begin{array}{c}70 \\
120\end{array}$ & $\begin{array}{l}110 \\
185\end{array}$ \\
\hline
\end{tabular}




\section{MOST SUITABLE OPERATING RANGES}

- An electrical resistivity between 2 to $15 \Omega . \mathrm{cm}$.

Around $15 \Omega . c m$ main difficulty is to start

- A viscosity at the running temperature.

Not above 150 poises

(temperature can generaly be adjusied) 


\section{An ANSWER to SOME QUESTIONS of the QUESTIONNAIRE}

- How to cope with the noble metals settling ?

$\rightarrow$ by using mechanical stirring

$\rightarrow$ by pouring from the bottom

$\rightarrow$ by limiting the residence time

CCM can do it 


\section{An ANSWER to SOME QUESTIONS of the QUESTIONNAIRE}

The foaming in case of liquid feeding ?

$\rightarrow$ it has never been seen

- neither with $R_{7} T_{7}$ composition

- nor with ENEA composition

$\rightarrow$ but it was

- working in oxidizing conditions

- separatly fed with solid glass frit in a laminated form

- using mechanical stirring 


\section{An ANSWER to SOME QUESTIONS of the QUESTIONNAIRE}

The clogging of the off-gas pipe

$\rightarrow$ only a thin deposit was observed in the off-gas pipe after 100 hours 


\section{ONGOING PROJECTS}

- Construction of the $\varnothing 65 \mathrm{~cm}$ CCM prototype at Marcoule ( to be implemented at La Hague )

- Qualification of the ACCM for large capacities at Marcoule and in a private company

- Vitrification of the HLW of ENEA in Saluggia (Italia) using a $\varnothing 55 \mathrm{~cm}$ liquid fed CCM

- Incineration-vitrification of the Korean reactor wastes: an R \& D joint venture with KEPRI and HYUNDAI

- Technical support to a new CCM to be implemented in the enamels industry 


\section{The KNOW-HOW for LARGE CAPACITIES}

The new ACCM concept which allows large sizes, therefore large capacities

The qualification work is done to day with 3 facilities

\begin{tabular}{|c|c|c|c|c|}
\hline \multirow[b]{2}{*}{$\begin{array}{c}\varnothing \\
\mathrm{cm}\end{array}$} & \multirow[b]{2}{*}{$\begin{array}{c}\text { power } \\
\text { kW }\end{array}$} & \multicolumn{2}{|c|}{ flowrate } & \\
\hline & & $\begin{array}{l}\text { liquid feed } \\
\qquad \mathrm{h}^{-1}\end{array}$ & $\begin{array}{c}\text { solid feed } \\
\mathrm{kg} \mathrm{h}^{-1}\end{array}$ & \\
\hline 65 & & 20 & 70 & \\
\hline 100 & 100 & 50 & 100 & CEA Marcoule \\
\hline 140 & 800 & $\begin{array}{l}\text { TBD } \\
>100\end{array}$ & $\begin{array}{l}\text { TBD } \\
>500\end{array}$ & Non nuclear industry \\
\hline
\end{tabular}

Discussions are in progress in order to built

a $1 \mathrm{MT} / \mathrm{hr}$ solid fed ACCM for non nuclear waste! 


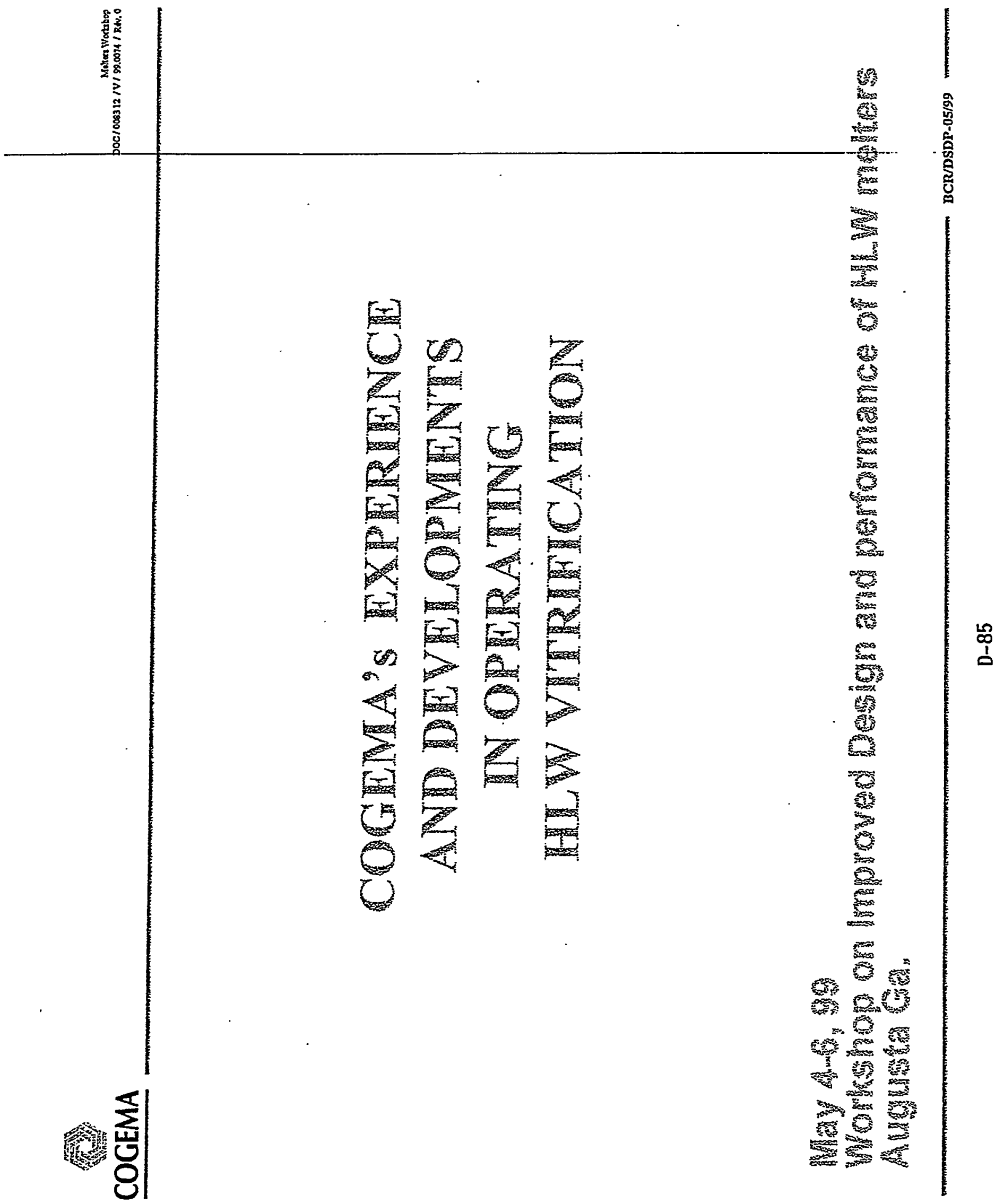




\section{SUMINAR}

COGEMA's Experience in Operating Industrial HLW Vitrification Facilities

Current projects :

The Cold Crucible Melter (CCM)

Anticipating Future needs :

The Advanced Cold Crucible Melter (ACCM)

Conclusion 
More than 20 years of experience in HLLW vitrification in an industrial environment

AVM, the world's first industrial vitrification plant started hot operations in 1978

Dont Continuous improvement of COGEMA's vitrification plants (AVM, R7, T7)

High records of availability, safety and product quality achieved 


\section{Ry}

\section{Long term and consistent R\&D efforts conducted by CEA for over forty years}

- Warly sclection of Borosilicate Glass for HLW

- Glass formulation tailored to waste composition and technology

- Long term behavior experience

- High waste loading

- High durability

- Continuons two step process (rotary calciner + metallic crucible)

- Modular, small size equipment

- Reliability, remotability

- Cold eracible development since the 80's with the objectives of

- Improved life time

- Overcome temperature limits 
COGEMA

\section{Gemeral Diagram of Two step process}

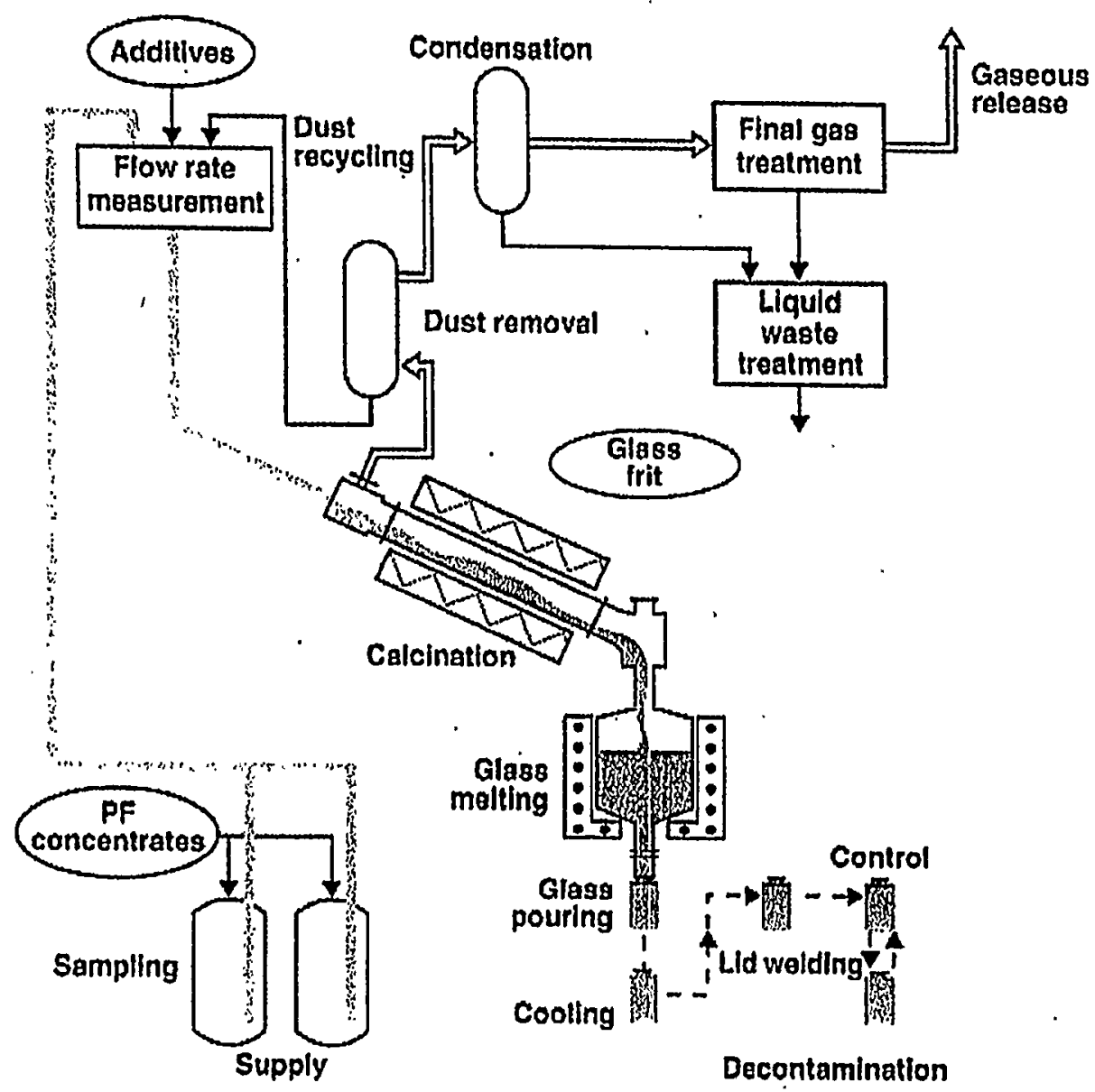




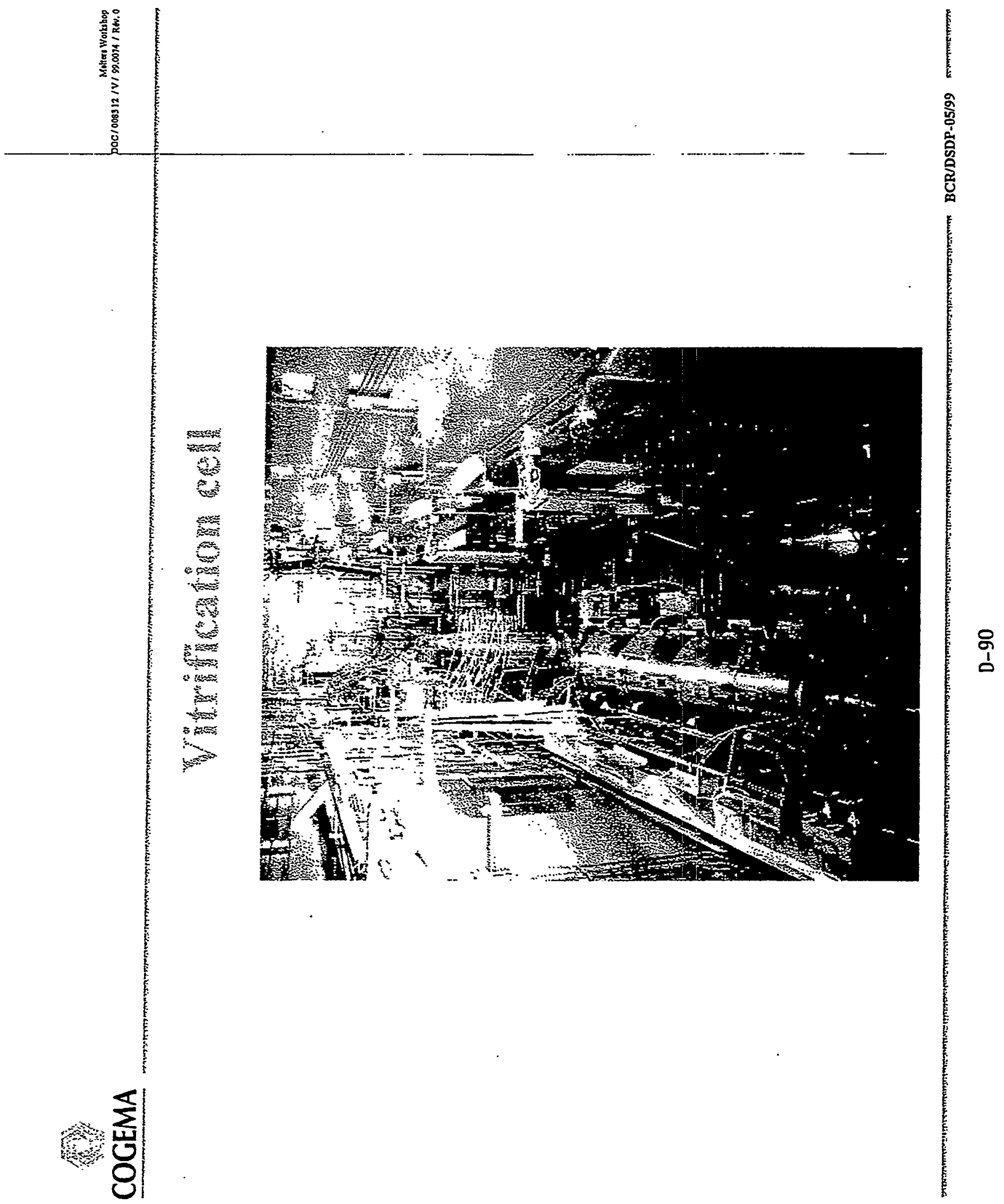


COGEMA

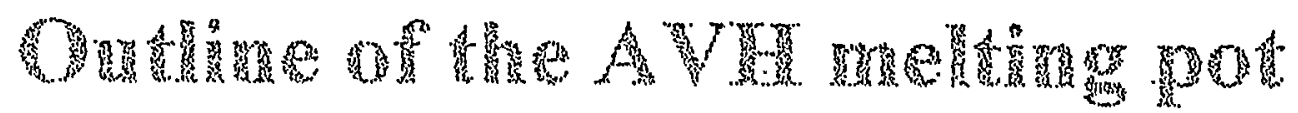

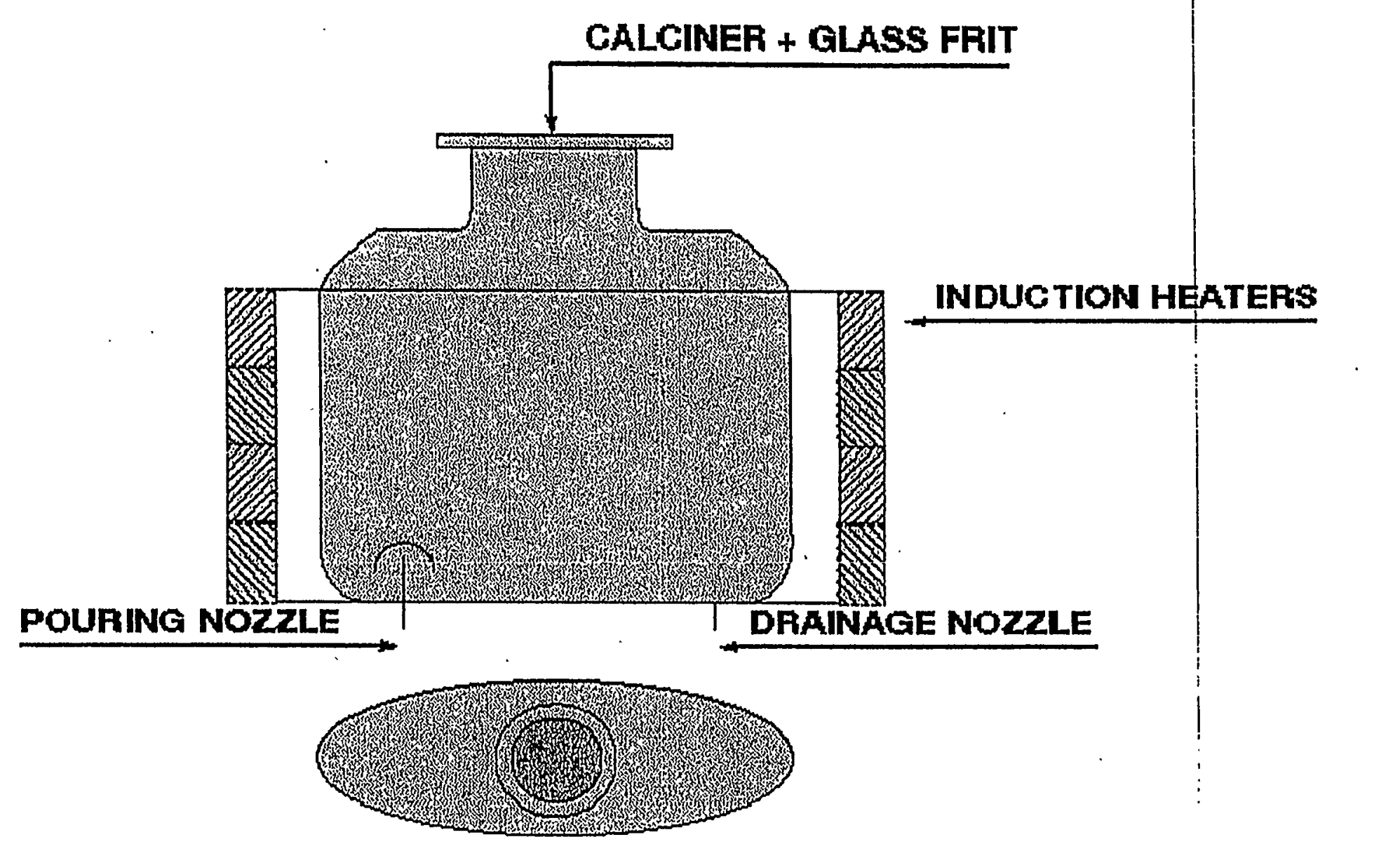




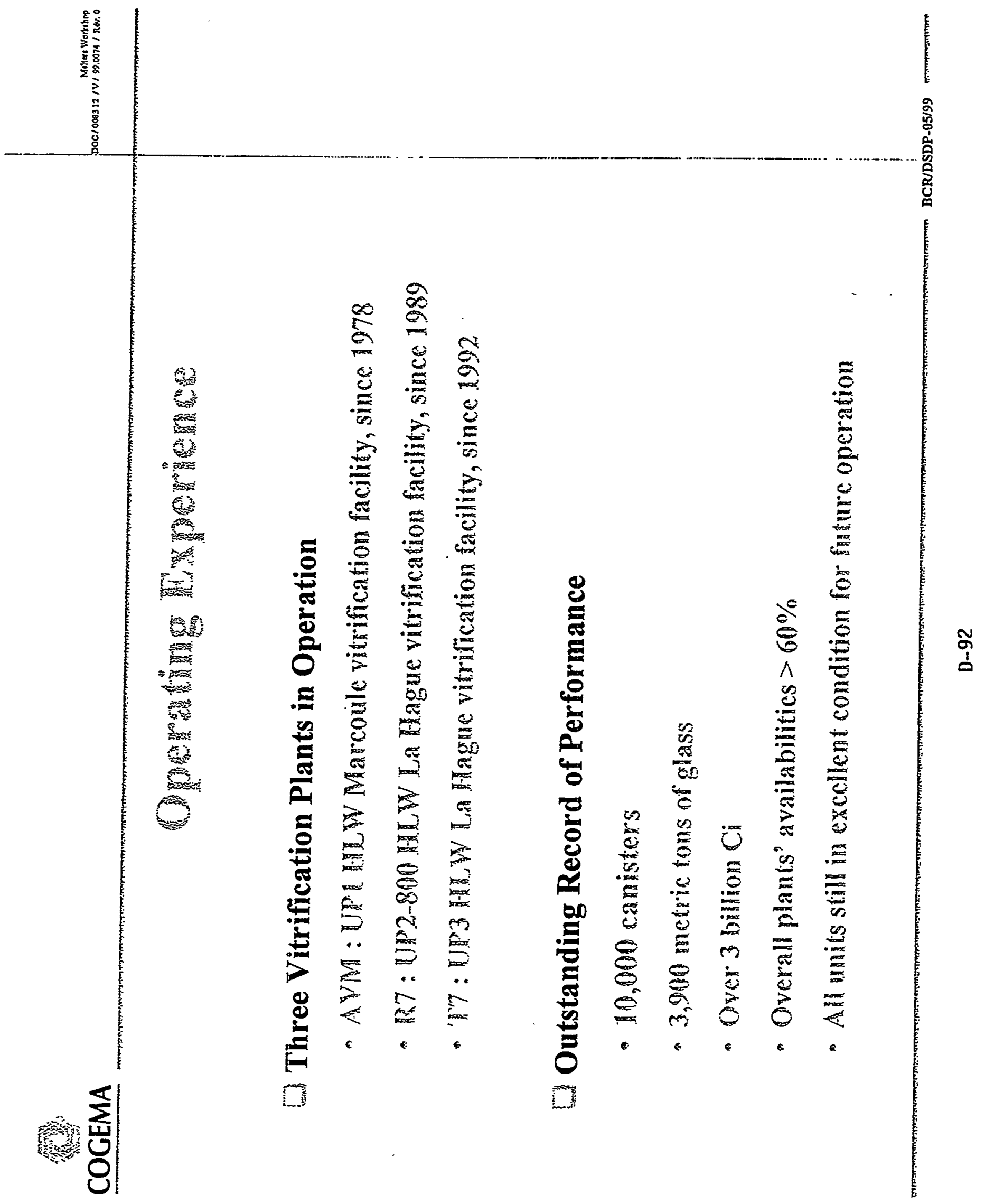




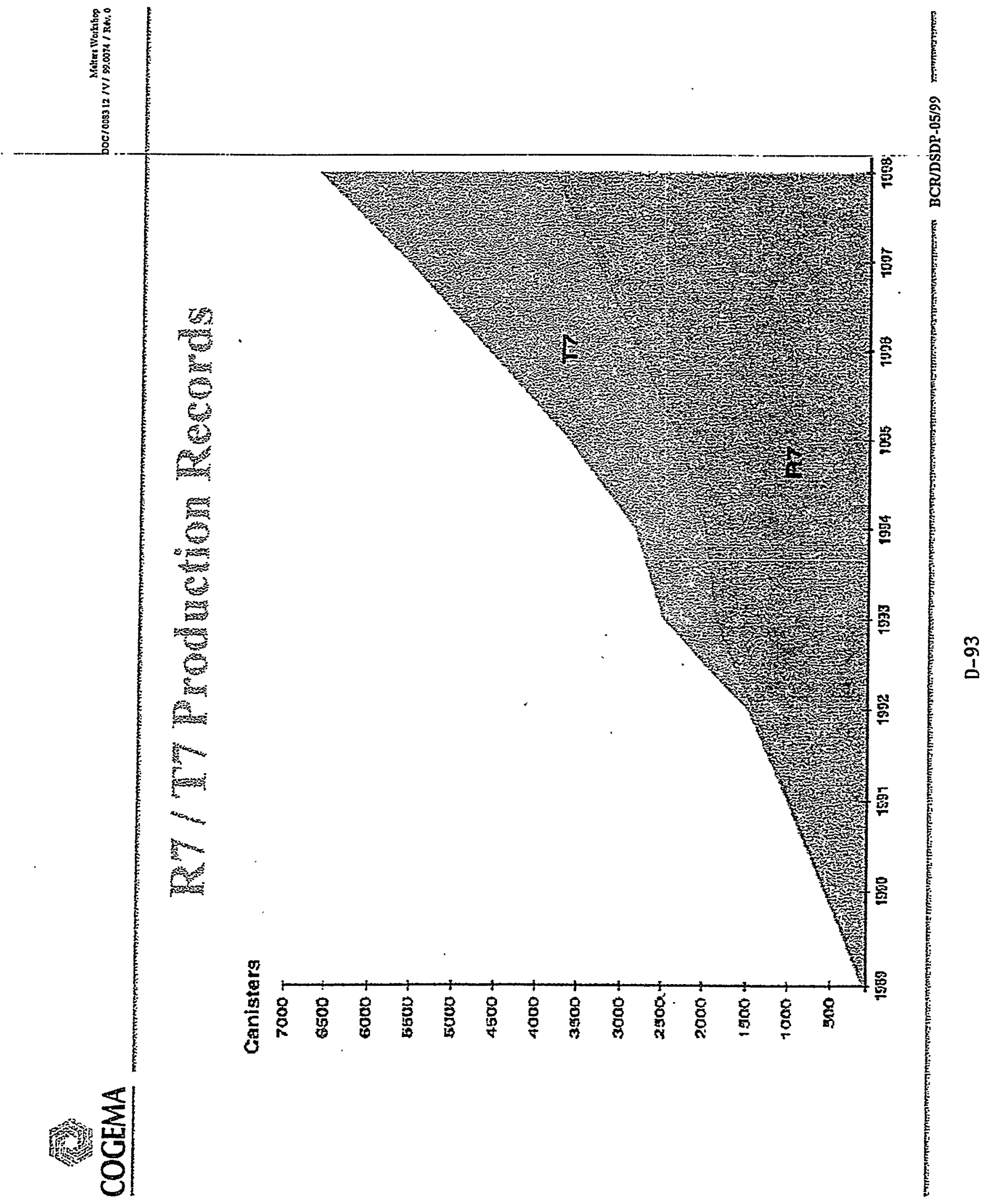



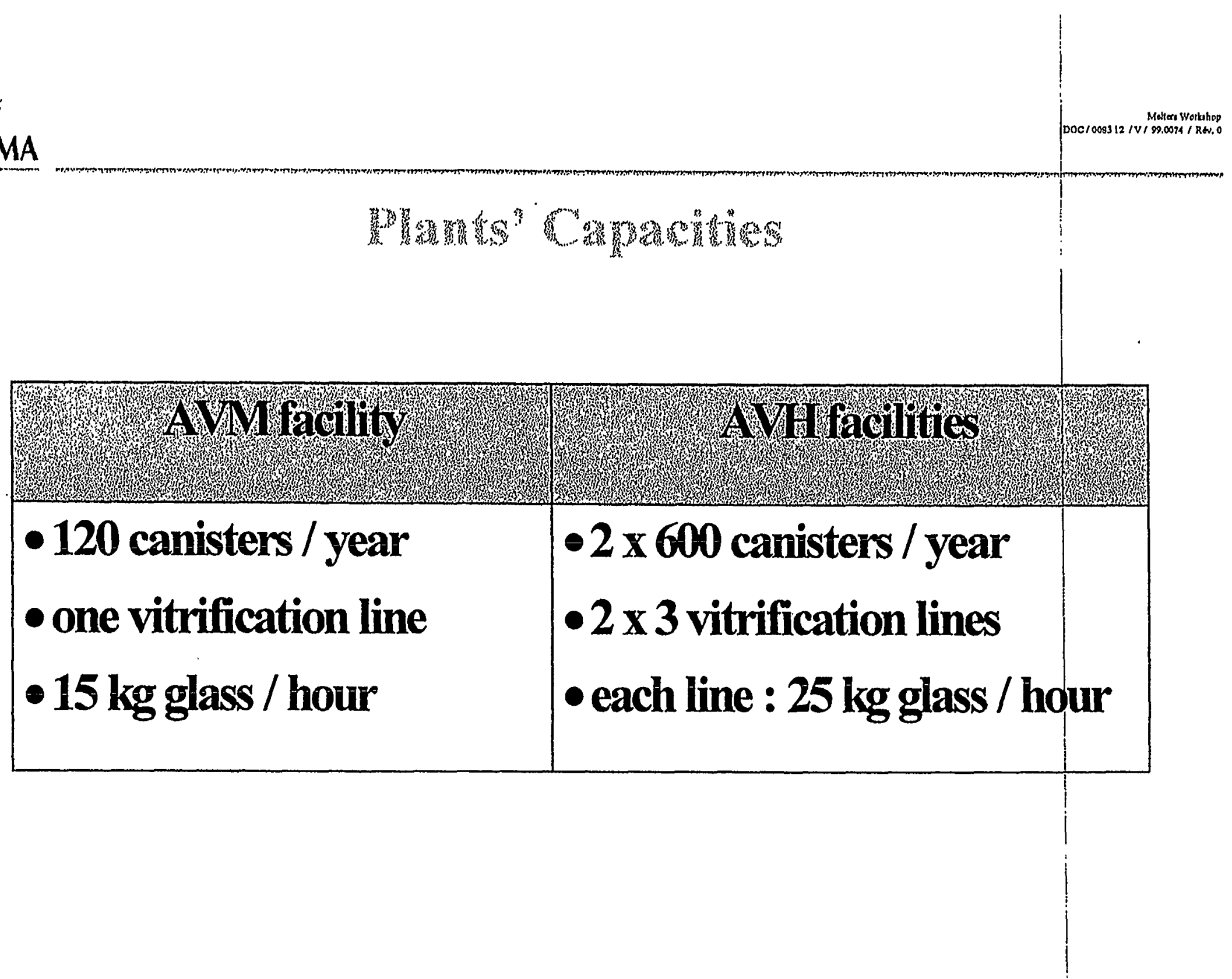


\section{COGEMA}

\section{Dosigng Approad}

Design Requirements

- Production availability,

- Minimize occupational exposure and environmental impact,

- Minamize sccondary solid waste generated by operations

\section{Design Options}

- Modwhar, small size, and maintainable cquipment

- Reliability of process and cquipment

- Optimized maintenance strategy (acconding to cquipment life-time)

- Compact process colls 


\section{Fed 首ach}

The plant design concept facilitates evolution and modification both in process and equipment

R7 was the first vitrification La Hague plant started-up in 1989

Feedback from R7 operations was taken into account in T7 design before hot start-up (1992)

- Hopprover tymamic containucnt in the pone spont bellows asscmbly

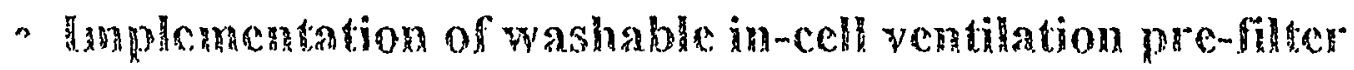

- Horomencol of in-cell remote handling cranes reliability

Upgrading of R7 facility (1994)

- Retrofitting from T7 experience

"Achiever in 9 months with low dose impact to personnd 


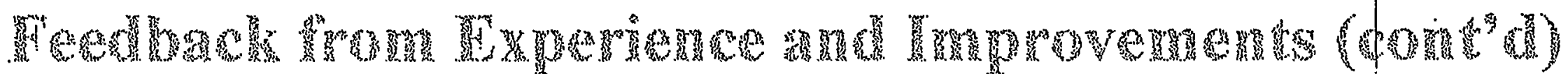

\section{Melter Life-time}

- Meber netime has a grent impact on phant availability and solid waste generated

- Design objective of 2000 hours was difficult to reach at the beginning of $f$ R7 opperation

- Inpprovensents through :

- Comprehensive R\&D program

- Material development (metallurgy, corrosion)

- Engineering design (power control, thermal and structural behavior)

- Present arerage bifeme is greater than 3500 hours 
COGEMA

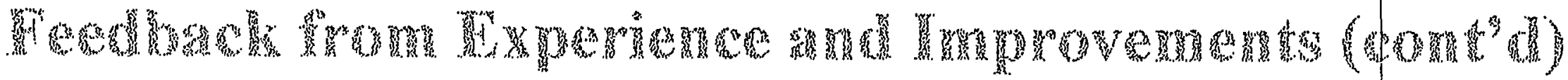

Maximum number of canisters produced with a single melter

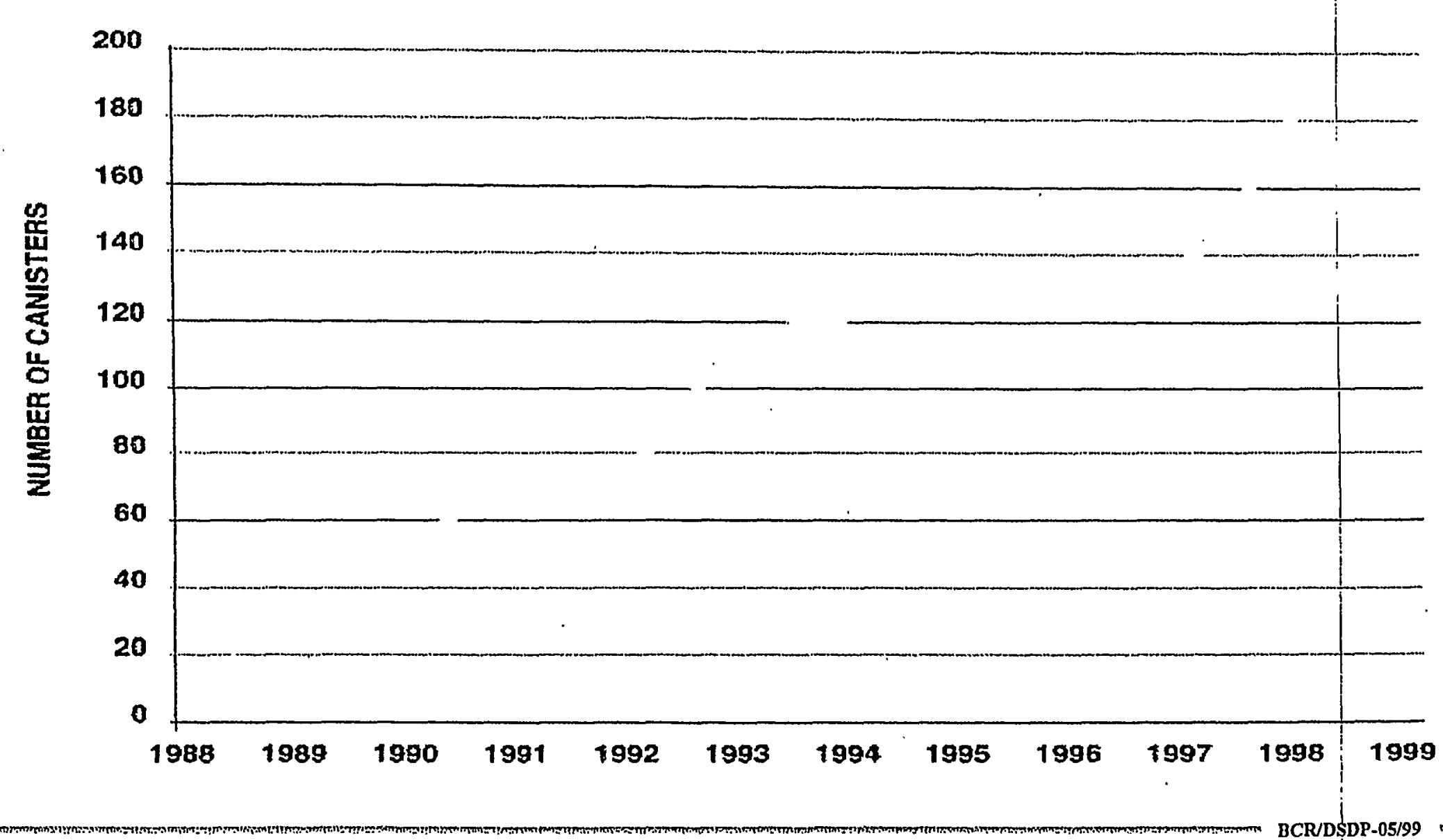




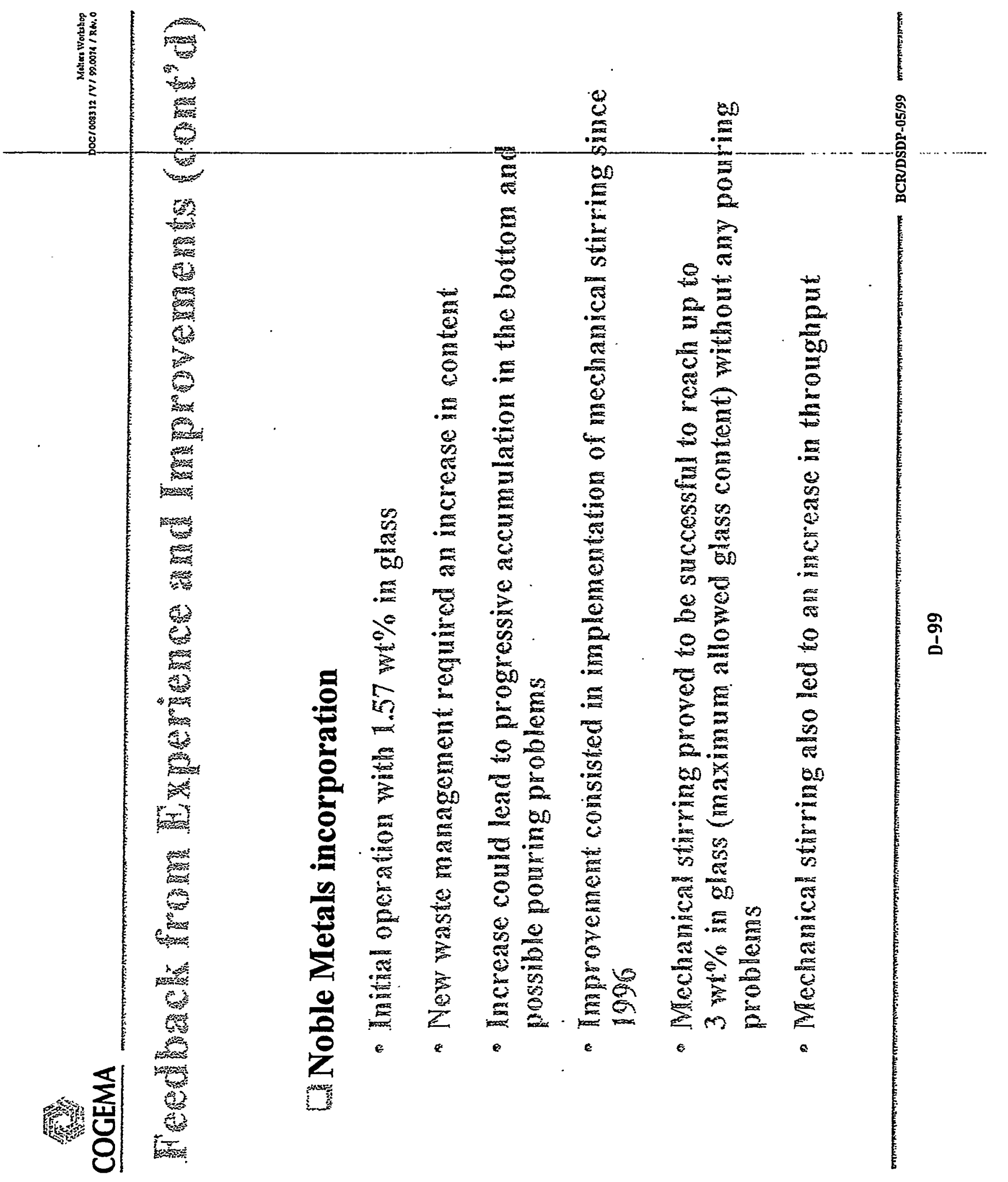




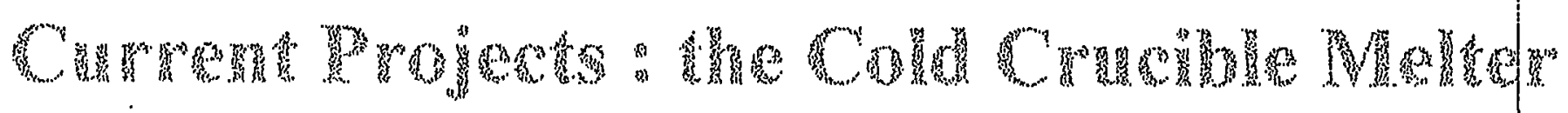

To further enhance the plants' performances COGEMA has selected the Cold Crucible technology developed by CEA

It is a proven technology which has been qualified by CEA in order to vitrify HLW solution as well as ILW or LLW solutions

This technology will overcome difficulties linked with corrosion and high temperature

COGEMA has decided to implement this technology for U-Mo fuel HLW processing

Installation of equipment will be performed remotely inside the existing hot cell

Start-up of one $\mathbf{R 7}$ line is scheduled for 2002 


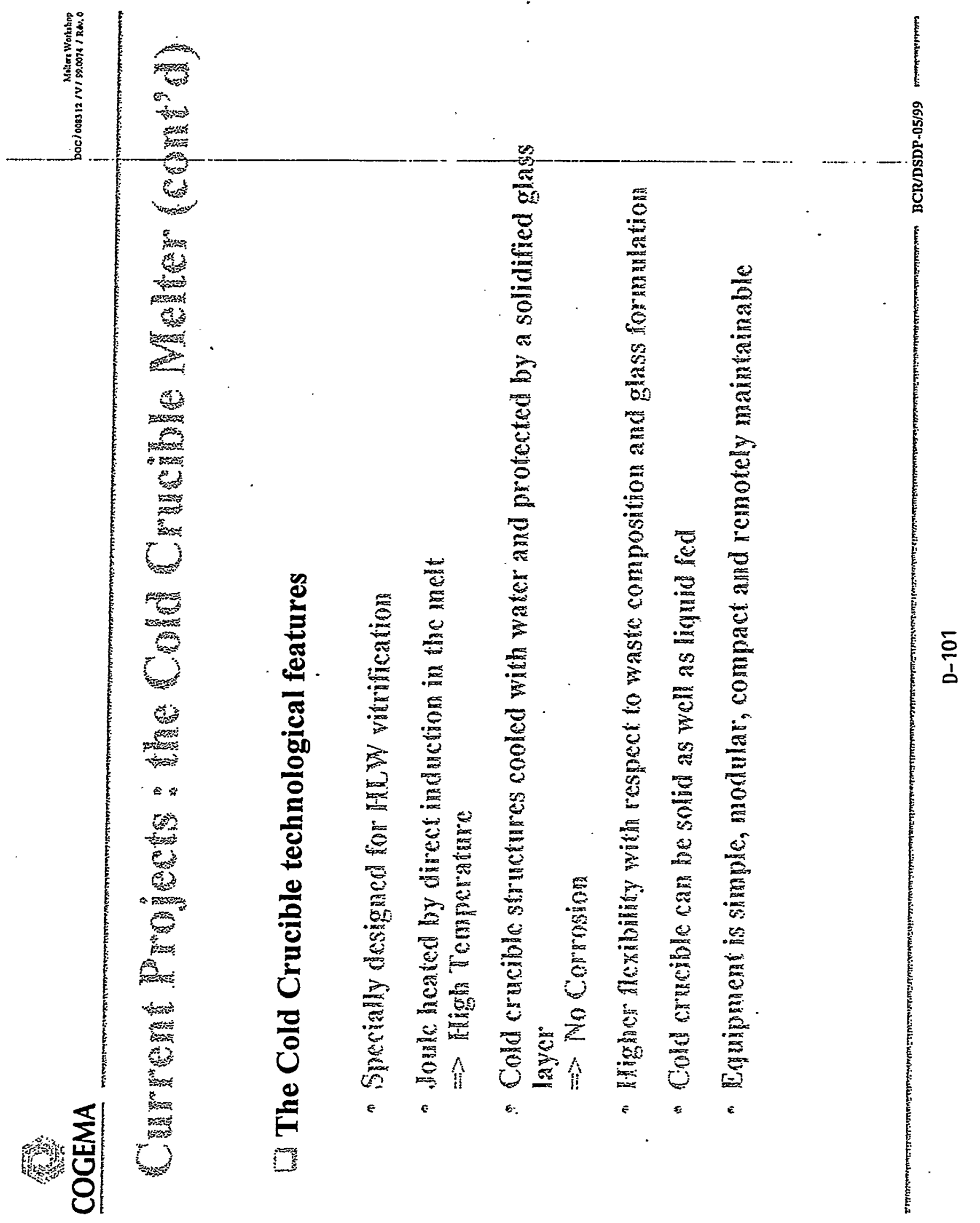




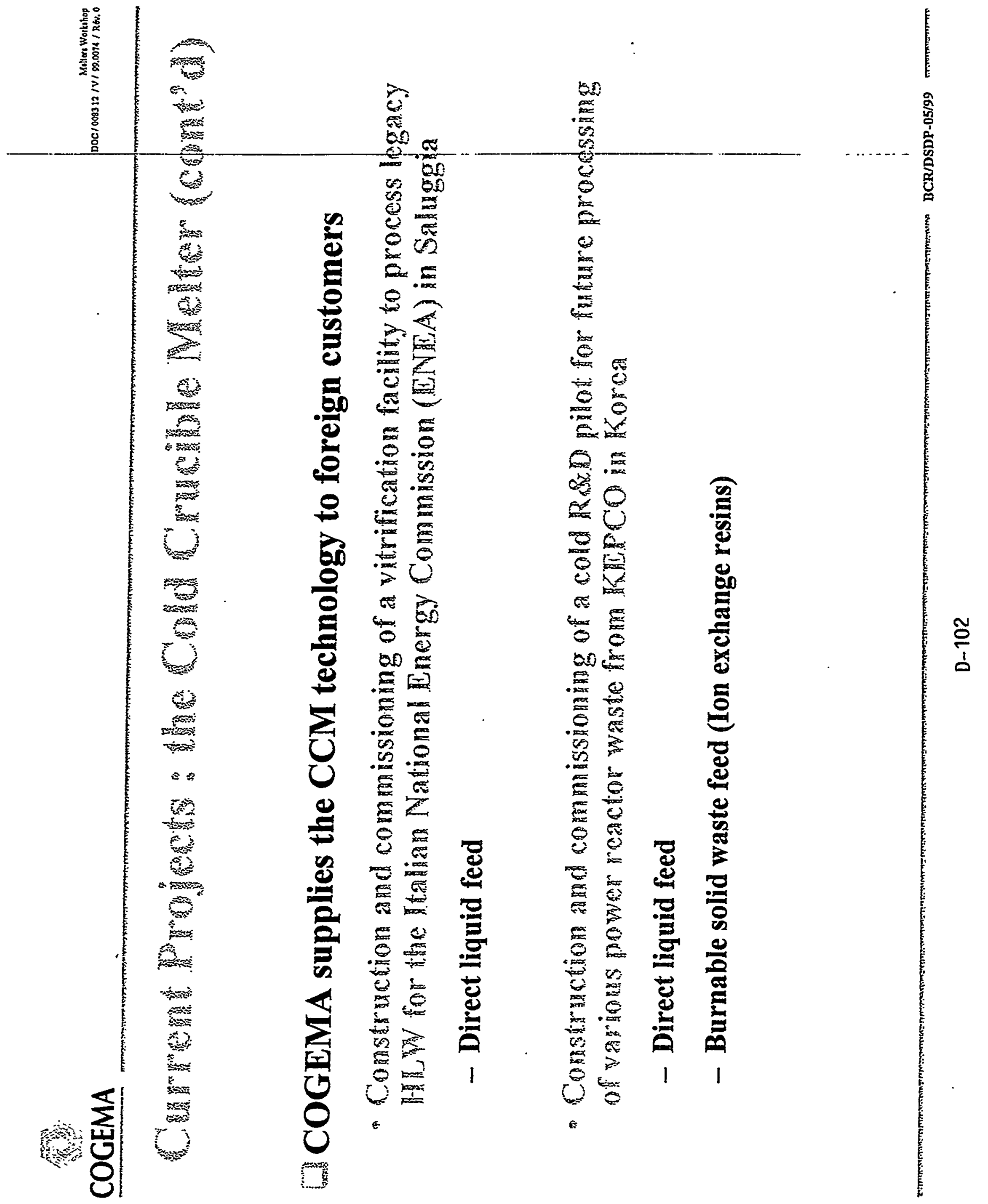


COGEMA

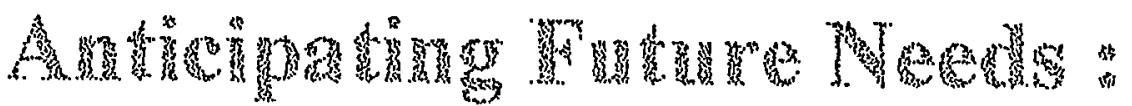 THe Advanded Cold Crmeinge Meller (ACCM)}

CEA and COGEMA have improved the technology a step further in anticipation of future worldwide vitrification needs for HLW as well as LLW

Process technology has been developed on Marcoule pilots since 1995

TCCM advantages

- The CCA advantages

- No Electrodes, No Corrosion, No Wear, Equipped with a stirring device

- A lnigg ger throughput

- Hosier cxtrapolation

- More modularity

- Mevar simpler 


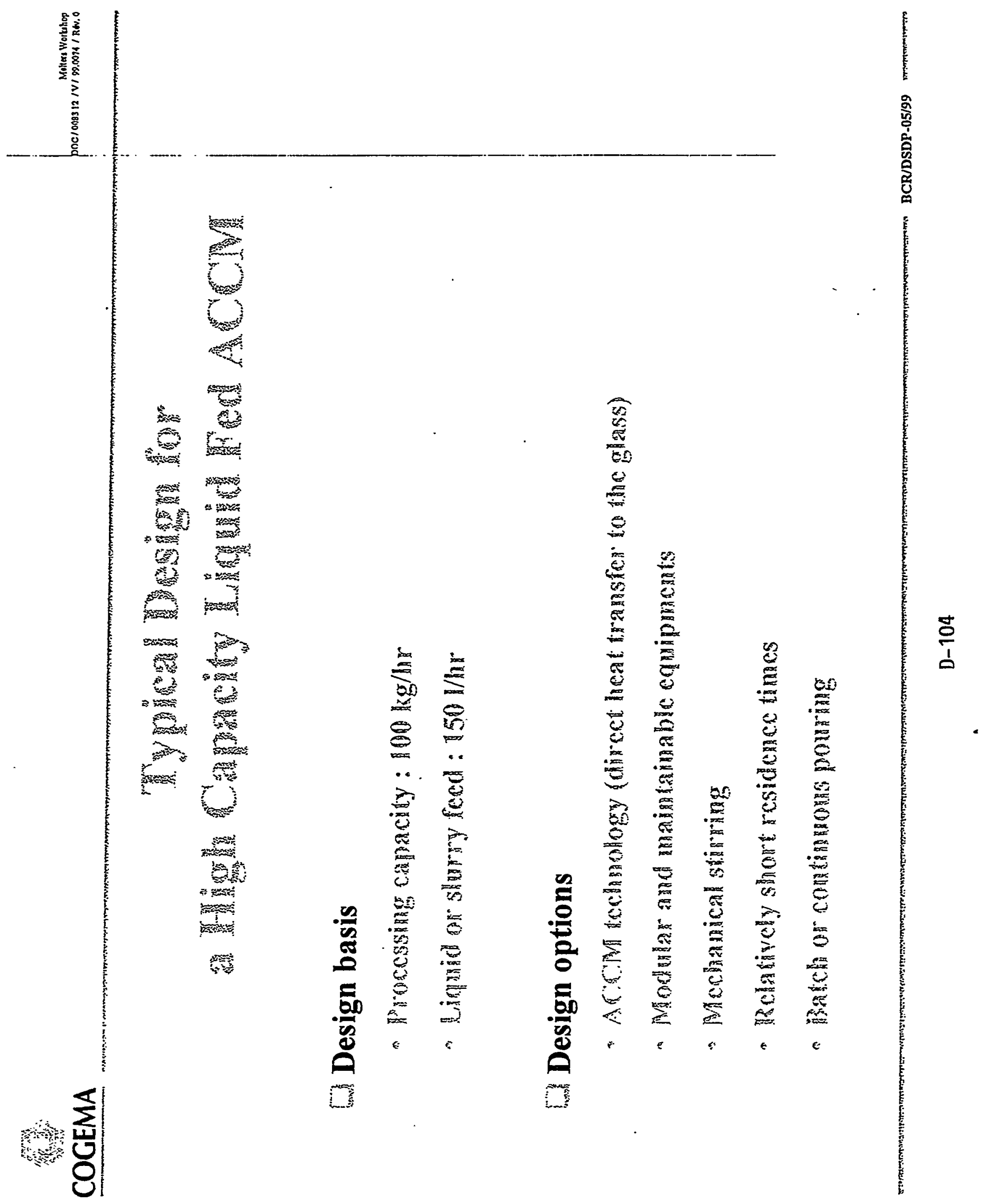




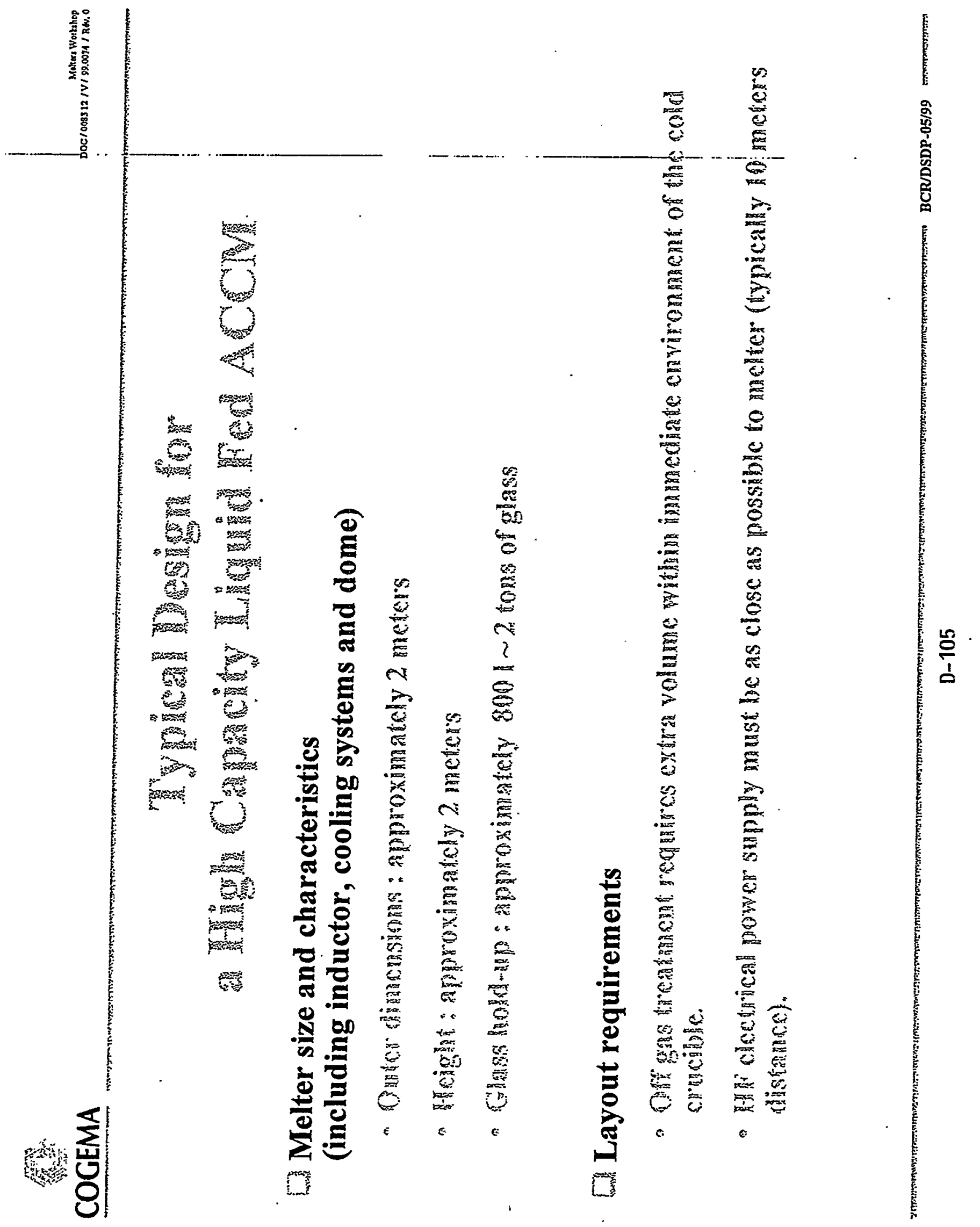




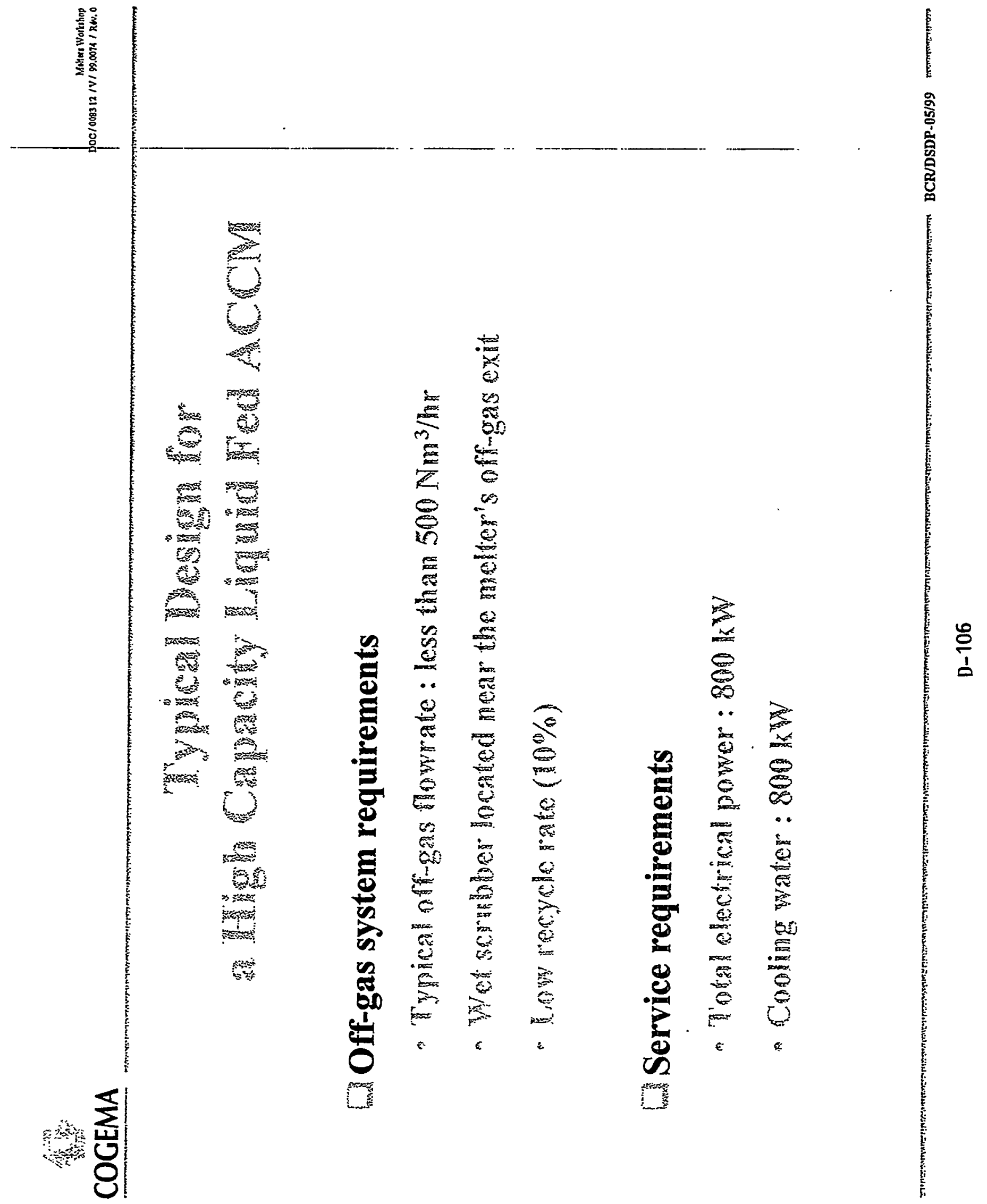




\section{COGEMA}

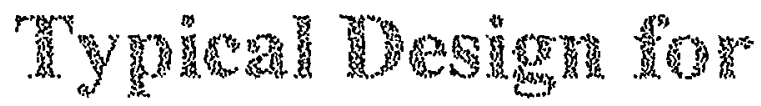

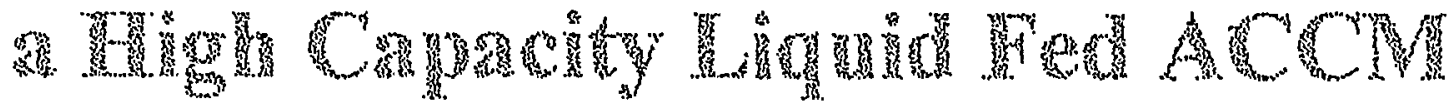

ACCM is modular and all sub-components are designed to be maintained in a remote environment.

ACCM can be completely disassembled from top down with small cranes and manipulators

- Smant sizc and weight of sub-componemis (<1 M

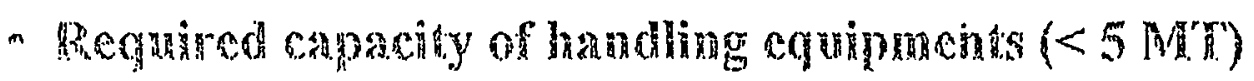

All maintenance is performed in cell with remote handling equipments

- Sufe oparations (minimal porsonnel oxpasare),

- Costerective openations. 


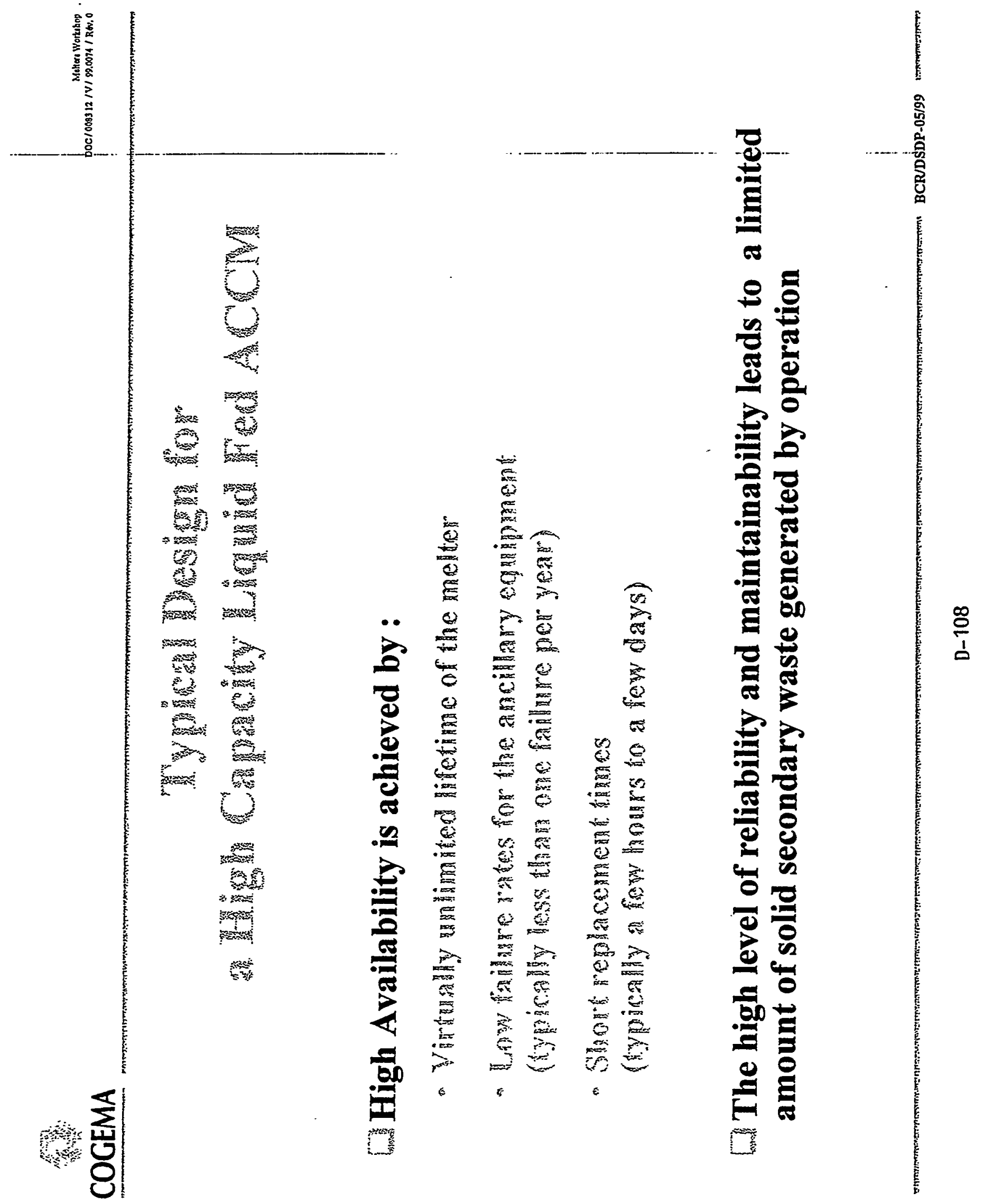


Anp ex amphe of high avallabiluy: COGWMA's approach

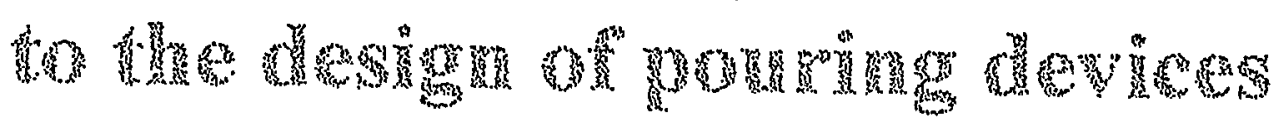

Since the start of industrial operation, COGEMA has always operated batch pouring

COGEMA's experience : 25,000 pouring cycles

A slide valve has been specially developed for the cold crucible technology

The valve is compact, modular and maintainable

- Total weight of valve equipment: less than $100 \mathrm{~kg}$

"Timac reguired for replacement: less than 2 days 


\section{CONCLUSOIN}

Continuous CEA R\&D efforts combined with COGEMA's operating experience have always been the basis for progress

The CCM technology is one significant step in this evolution for waste vitrification

$\square$ The processing of U-Mo HLW at La Hague will confirm the advantages of the CCM technology at an industrial scale as soon as year 2002

COGEMA believes that the Cold Crucible Melter technology will be able to meet most of tomorrow's needs in terms of radioactive waste solidification

The ACCM development being most appropriate for large throughput requirements and especially for US applications 


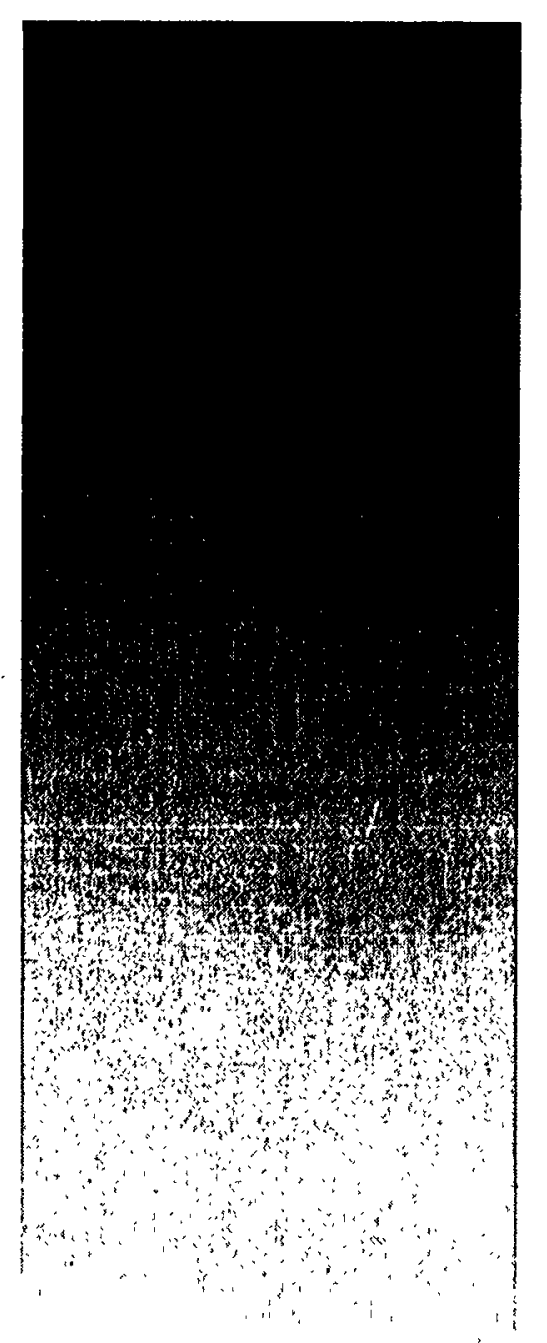

\title{
INEEL High-Level Waste Program Review
}

\author{
J. A. Rindfleisch/LMITCO \\ May 5, 1999
}




\section{Program Goals}

- Waste Reduction-Minimization/Segregation

- Waste Sampling \& Characterization

- Off-Gas Sampling

- Tank Closure \& Closure of Inactive Processes

- Treatment of Liquid \& Solids Wastes

- Environmental Impact Statement (EIS) as Basis for Future Waste Treatment Decisions 


\section{Program Goals (continued)}

- Technical Development in preparation of path forward

- Flowsheet/Mass Balance

- Waste Acceptance Criteria

- Calcine Dissolution

- Solid/Liquid Separation

- RCRA component Disposition

- Separations (Cs, Sr, Actinides/TRU) 

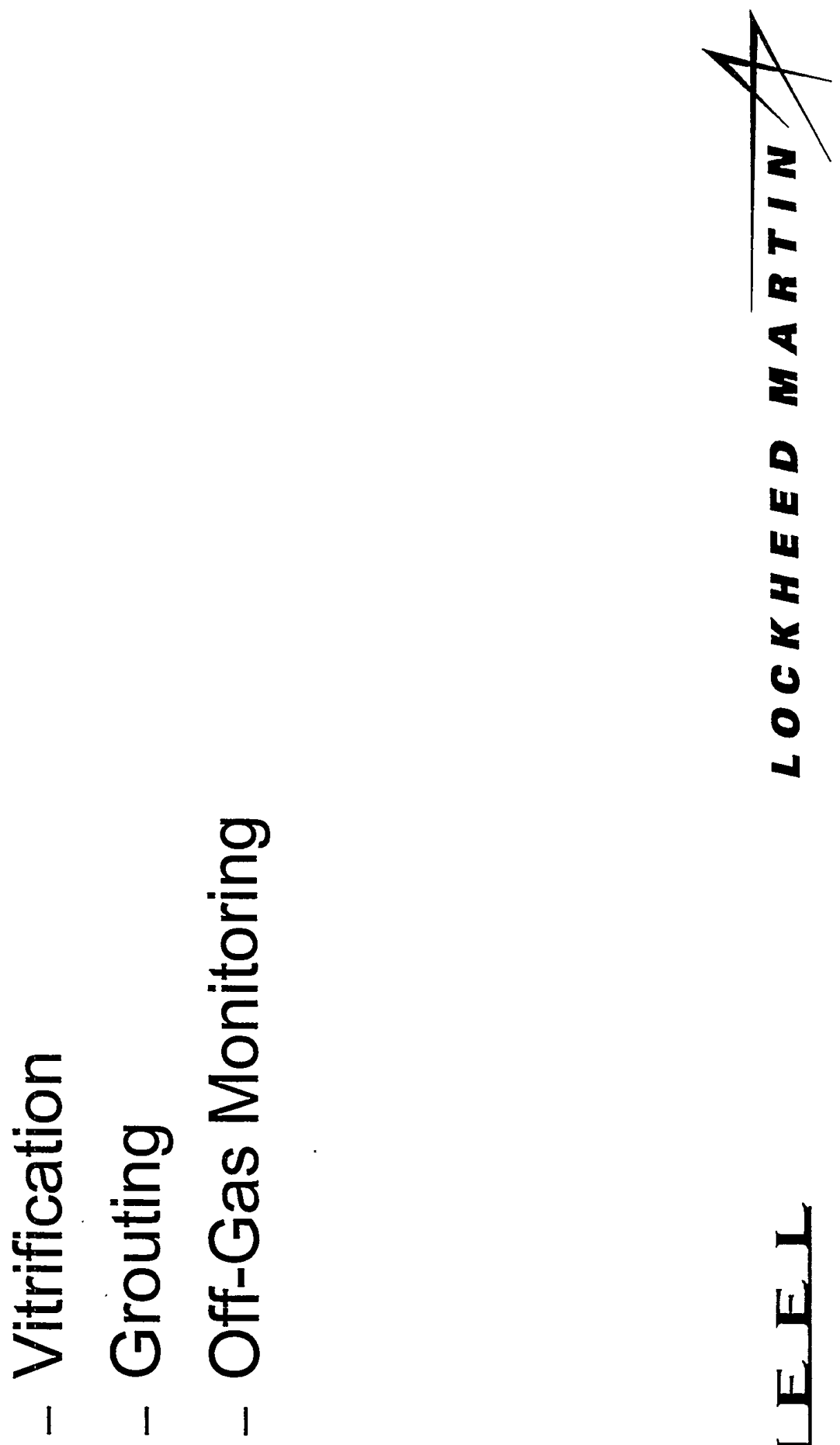

$\frac{8}{1}$

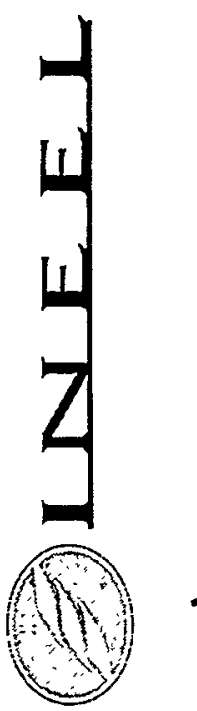




\section{Milestones}

- By July 31, 1999, DOE shall submit a report detailing the past studies, current status, and estimated life of the eleven 300,000-gallon INTEC tanks

- Complete Draft EIS for HLW treatment by Summer 1999

- Complete EIS for HLW treatment by Fall 1999 


\section{Milestones (cont)}

- By November 15, 1999, DOE shall submit report amendment containing a long-term plan for tank inspection and evaluation

- Implement ROD by June 2000

- Calciner required to go into standby by June 1,2000 until it is permitted

- Closure plan for one tank required by December 31, 2000 


\section{Milestones (cont.)}

- Start Facility Conceptual Design 2002

- Cease use of pillar and panel vaulted tanks by June 30, 2003

- Complete Conceptual Design 2004

- Complete Title Design 2008

- Part B Permit 2009

- Complete caicining of sodium-bearing liquid waste by 2012 


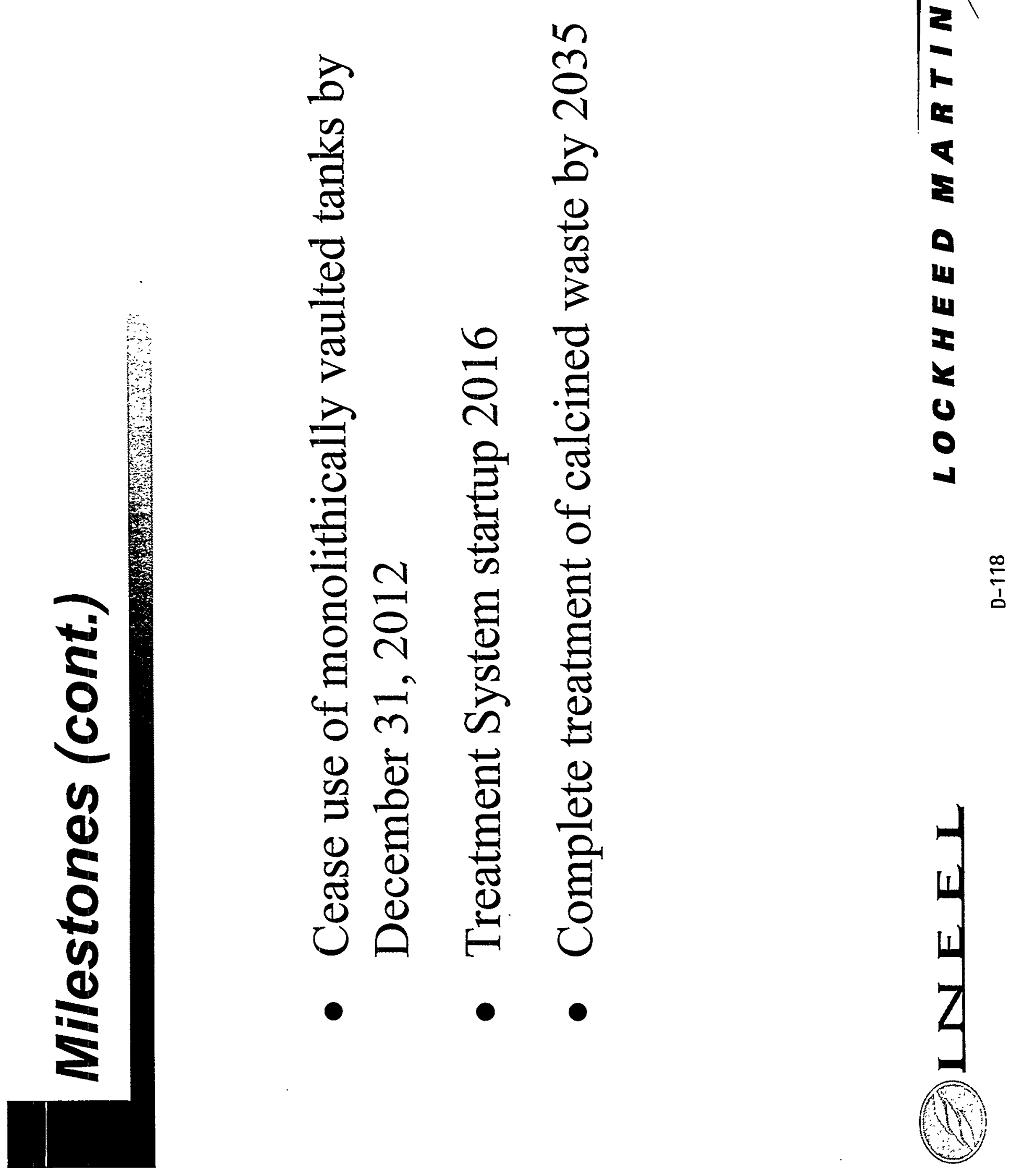




\section{Some Recent Successes}

- First Calciner Off-Gas Data Gathered

- Light Duty Utility Arm Used to Take Four Samples from Tank WM-188.

- Waste Minimization of $44.3 \%$ Reduction in Tank Farm Inputs

- Calciner to operate through June 2000 


\title{
INEEL High Level Waste Program - Project Engineering
}

\author{
Rod Kimmitt/LMITCO
}




\section{High Level Waste Treatment Waste Streams}

- Calcine

- 4,500 cubic meters

- granules include $\mathrm{CaF}_{2}, \mathrm{ZrO}_{2}, \mathrm{Al}_{2} \mathrm{O}_{3}$, heavy metal oxides, nitrates, sulfates

- Liquid Waste (Sodium-Bearing Waste - SBW)

- $\quad \sim 4$ million liters

- $\quad \sim 2$ molar nitric acid

- $\quad$ liquid waste from reprocessing has been calcined

- inventory is decontamination solution 


\section{High Level Waste Treatment Waste Streams (cont'd)}

- High Activity Waste from Separations

- 307,000 liters of liquid HAW from SBW

- 3,020,000 liters of liquid HAW from calcine

- $\quad$ Lockheed Martin Engineering Estimate 


\section{High Level Waste}

- National Environmental Policy Act (NEPA)

- all significant federal activities must evaluate environmental impacts

- Environmental Impact Statement (EIS)

- consider options, including "no action"

- must provide for public input

- concludes with formal "record of decision"

- public comment period starts in Summer, 1999

- record of decision expected in by June, 2000 


\section{High Level Waste (cont'd)}

- DOE Settlement Agreement with State of Idaho

- $\quad$ all liquid waste must be treated by end of 2012

- all HLW treated and ready for movement out of state by end of 2035

- Environmental Protection Agency (EPA)

- requires vitrification for HLW to meet Land Disposal Restrictions 


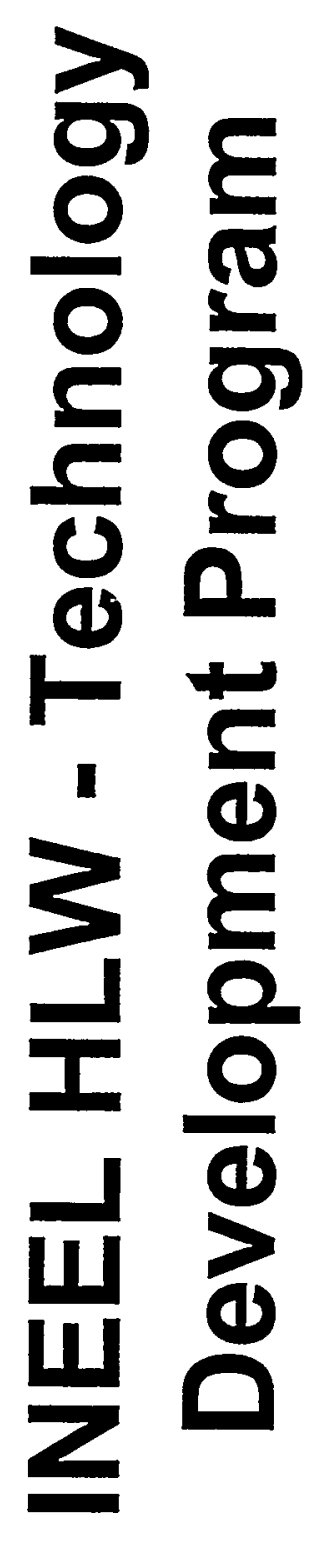

$\frac{5}{n}$
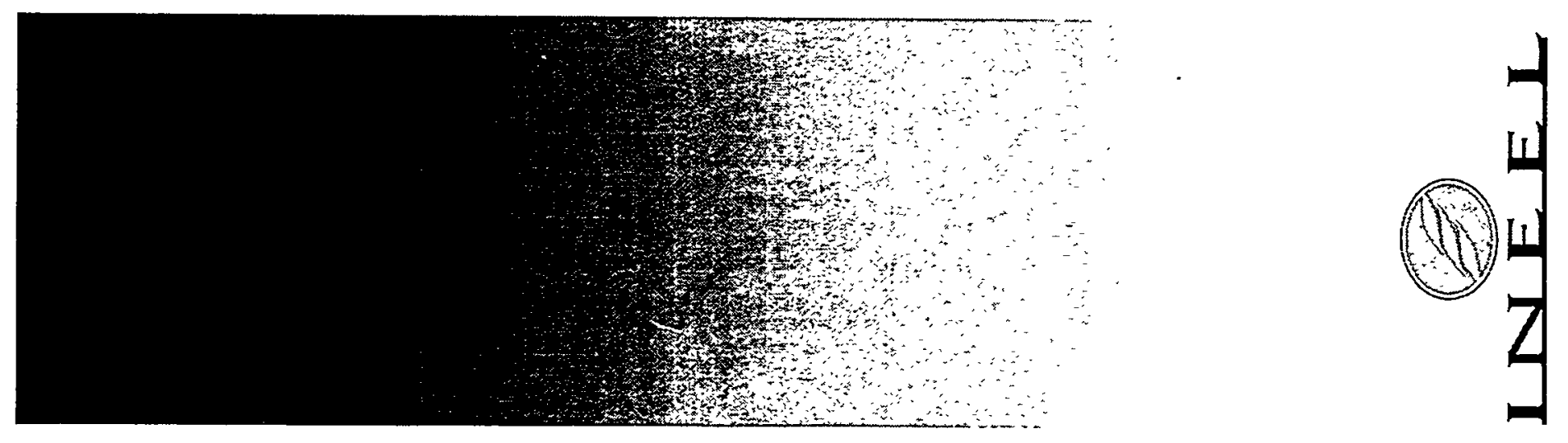


\section{Current Status of INEEL HLW Process Development Program:}

- Conducting Treatability Studies on Direct Vitrification of Calcine and Sodium Bearing Waste.

- Reviewing and Providing Feedback on Baseline. Separation Flowsheet

- Evaluating Vitrification Processes and Gathering Process Data to Support EIS Alternatives. 


\section{Scope of Work for Direct Vitrification:}

- Perform Pilot Scale Melter Testing at Clemson University with Simulated Liquid Sodium Bearing Waste at $1150^{\circ} \mathrm{C}$.

- Perform Pilot Scale Melter Testing at Clemsom University with Simulated Calcine Waste at $1150^{\circ} \mathrm{C}$.

- Perform Pilot Scale Melter Testing at Clemson University with Simulated Calcine Waste at $1450^{\circ} \mathrm{C}$. 


\section{PILOT SCALE MELTER TEST OBJECTIVES WITH SBW:}

- Determine preliminary processing rates of liquid sodium bearing waste.

- Determine if a molten salt " $\mathrm{SO}_{3}$ " is formed in the melter and it's effects to materials of construction/off-gas treatment.

- Can liquid sodium bearing waste be directly vitrified. If so, what is the total volume of glass from SBW processing. 


\section{PILOT SCALE MELTER TEST OBJECTIVES WITH SBW (Cont):}

- Determine, if any, the pretreatment requirements for processing SBW?

- Utilize Experimental Test results, with respect to nitrates and water, for determinng processing rate of SBw and HAW.

- Determine volatile species from processing the liquid SBW. 


\section{PILOT SCALE MELTER TEST FOR PROCESSING SIMULATED CALCINE AT $1150^{\circ}$ AND $1450^{\circ} \mathrm{C}$}

\section{Objectives:}

- Determine preliminary processing rates for treating calcine at $1150^{\circ} \mathrm{C}$ and $1450^{\circ} \mathrm{C}$.

- Evaluate the behavior of Fluorine in the melter. How much stays in the glass?

- Corrosion of melter materials of construction and off-gas components.

- What are the volatile species from processing the calcine. 
Pilot Scale Melter Test Objectives for Processing Simulated Calcine at $1150^{\circ} \mathrm{C}$ and $1450^{\circ} \mathrm{C}$ (Cont):

- Can calcine be immobilized via vitrification at $1150^{\circ} \mathrm{C}$ and $1450^{\circ} \mathrm{C}$ ?

- Advantages/Disadvantages of processing calcine at $1150^{\circ} \mathrm{C}$ and $1450^{\circ} \mathrm{C}$.

- Determine total glass volumes from vitrifying INEEL calcine.

- Determine if any pretreatment of calcine is required prior to vitrification. 


\section{GENERAL MELTER OPERATIONS}

1. A re steps routinely taken to control redox potential in the melt? If so, how is it done? A re oxidizing or reducing conditions $\mathrm{m}$ ain tained?

2. INEEL high level waste compositions consist of high am ounts of $\mathrm{CaF}_{2}$ and $\mathrm{P}_{2} \mathrm{O}_{5}$, will $1450^{\circ} \mathrm{C}$ processing tem perature result in higher waste loading's than $1150^{\circ} \mathrm{C}$ processing tem perature?

3. Fluorine volatility presents serious corrosion issues to the materials of construction of melter components. (i.e. Off-gas, refractory, etc.) A ssuming cold-cap operations, will fluorine volatility be greater at $1450^{\circ} \mathrm{C}$ operating tem peratures as compared to $1150^{\circ} \mathrm{C}$ operations?

4. The total $\mathrm{HAW}$ from calcine that requires im mobilization is $1.83 \mathrm{x}$ $10^{6}$ liters (Does not include UDS). The HAW fraction consists of 5 molar nitric acid, what are the advantages and disadvantages of denitration prior to feeding the melter?

5. A re their test data and safety analysis documents available that address the use of catalysts (i.e sugar, activated carbon, urea, etc.) for denitrating the feed in a glass melter? 


\section{Joule Heated Melting}

1. What is the expected operating life of a production melter?

2. What operations problems have been encountered with the DWPF melter?

3. How does DWPF plan to decontaminate, dismantle, and dispose of a melter(s) taken out of service?

4. What is the temperature in the melter lid during operation at DWPF? The TVS seemed to have a large amount of air in-leakage when it operated in Oak Ridge. What is the air in-leakage rate in the DW PF melter? 


\section{Induction Melting}

1. Can waste be fed as a liquid/slurry?

2. Can an induction melter be operated on a continuous basis rather than batch? If so, can a "cold cap" be maintained?

3. For a cold crucible melter, what is the typical heat loss in the cooling system, as a percentage of the energy fed to the melter?

4. W hat is the typical temperature rise for the cooling water?

5. It is my understanding that cold crucible melters have been studied for at least 10 years. Have any units been employed in a production environment? 


\section{Induction Melting}

1. How large are the cold crucible melters that have been developed (physical dimensions, glass production capacity)?

2. What operational problems have been encountered with cold crucible melters?

3. How is the cold crucible affected by changes in feed composition? What species would be of greatest concern?

4. Is there a cold crucible melter that is available for testing surrogate materials?

5. Is the solidified material (cold wall) difficult to maintain if the feed composition varies? 


\section{Waste Certification}

1. How does DWPF implement certification?

2. What changes in the current certification methodology would be required to feed dry waste to the melter? 


\section{VITRIFICATION FORMULATION DEVELOPMENT ACTIVITIES FOR INTEC HLW}

Bruce Staples/LMITCO 


\title{
Technical Collaborators/Contributors
}

\author{
INTEC/INEEL \\ C. A. Musick \\ B. A. Scholes \\ B. A. Staples \\ PNNL \\ G. F. Piepel \\ J. D. Vienna \\ SRTC \\ T. B. Edwards \\ C. M. Jantzen \\ D. K. Peeler
}




\section{INTEC WASTE COMPOSITIONS}

Calcines

High in $\mathrm{Zr}, \mathrm{Ca}, \mathrm{F}$ and/or Al, Noble Metals

HAWs

High in $\mathrm{Zr}, \mathrm{Al}, \mathrm{K}, \mathrm{P}, \mathrm{MO}, \mathrm{Sr}, \mathrm{F}$, Noble Metals 


\section{COMPOSITION VARIATION STUDY (CVS) APRROACH}

1. EM50/TFA Funding begins in FY98

2. April 1997 estimate of HAW composition used

3. PNNL mixture analysis techniques applied to HAW component ranges

4. Phase 1 formulation matrix results 


\section{INTEC GLASS COMPOSITION VARIATION STUDY (CVS)}

Phase 1: To define glass propertycomposition relations for HAW

Phase 2: To define glass propertycomposition relationships for direct vitrification \& HAW 
$\omega$

山

c

क

$\frac{5}{01}$

山

क

$\frac{T}{2}$

4

$N$

a

W

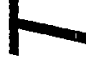

0

$\nabla$

난

$\checkmark$

$\frac{1}{0}$
(2)

(1)

$\sigma_{0} \frac{\omega}{00}$

$\infty$

$\mathrm{O}$

()

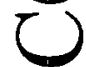

()

$\overbrace{0}^{0}$

$\sum_{0}^{1} \underbrace{\infty}_{0} \underbrace{\infty}_{0}$

$\sum_{0}^{\infty}$

- 0 \% 00

$\sum_{0}^{\infty} \sum_{0}^{0}$

i $\dot{r} \dot{\nabla}$

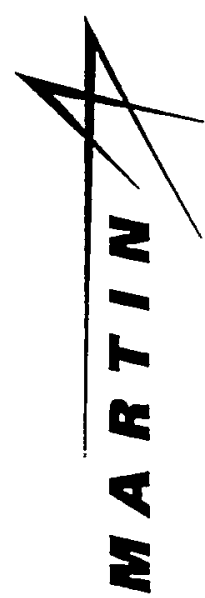

a

III

III

2

1

(b)

0

-

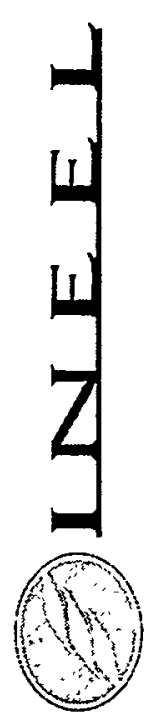




\section{PCT-A Results}

(Log NL elements $g / L$ Ranges)

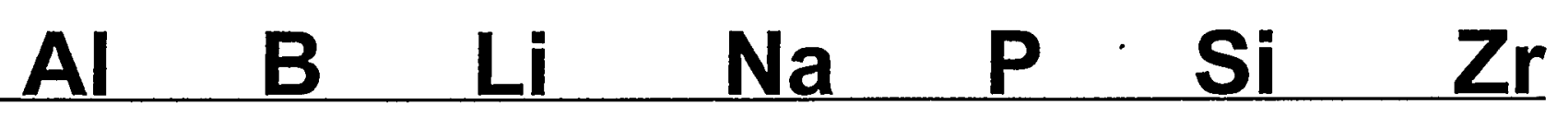

$\begin{array}{llllllll}\text { High } & -0.15 & 1.77 & 1.67 & 1.76 & 1.62 & 1.60 & -0.33\end{array}$

$\begin{array}{llllllll}\text { Low } & -1.47 & -0.52 & -0.98 & -0.94 & -0.73 & -0.66 & -2.75\end{array}$ 


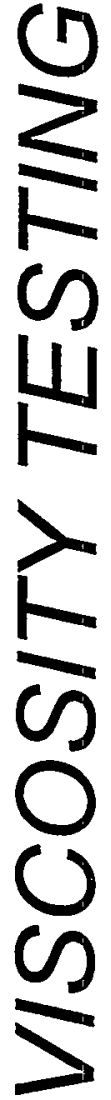

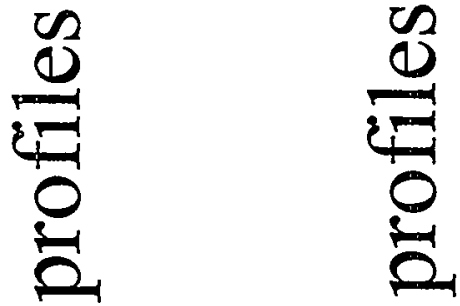

0

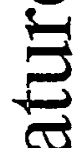

(1)

E

7

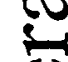

(1)

$p$

0

-

in

0

N 0

A $\frac{0}{0}$

d

$\frac{1}{B}$

08

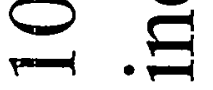

$\dot{1}$

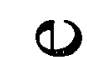

$\$$

ช

(1)

E

(1)

8

U ob

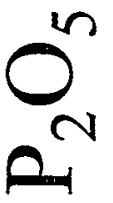

일

$+\frac{\theta}{\beta}$

$\infty 8$

$\rightarrow 0$

ก.

i

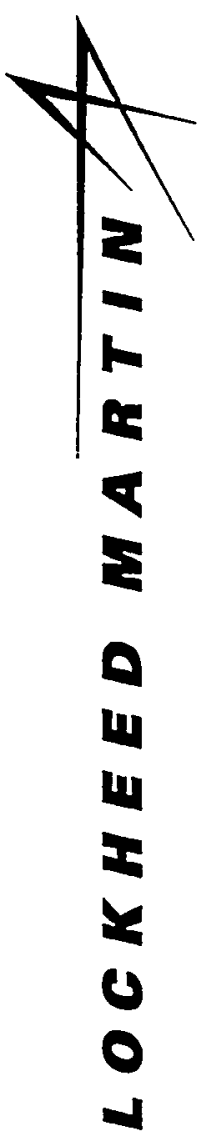

$\frac{⿱}{d}$

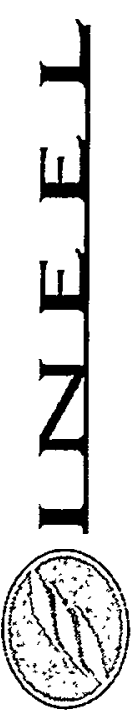




\section{$T_{L}$ Results}

Glasses with $\mathrm{P}_{2} \underline{\mathrm{O}}_{\underline{5}}$

1. $\mathrm{Li}_{3} \mathrm{PO}_{4}$, sometimes $\mathrm{Na}_{3} \mathrm{PO}_{4}, \mathrm{Li}_{2} \mathrm{NaPO}_{4}$ are primary phases

2. $T_{L}$ ranges from $811^{\circ} \mathrm{C}$ to $954^{\circ} \mathrm{C}$

3. Minor amounts of alkali silicates, alkali zirconium silicates 


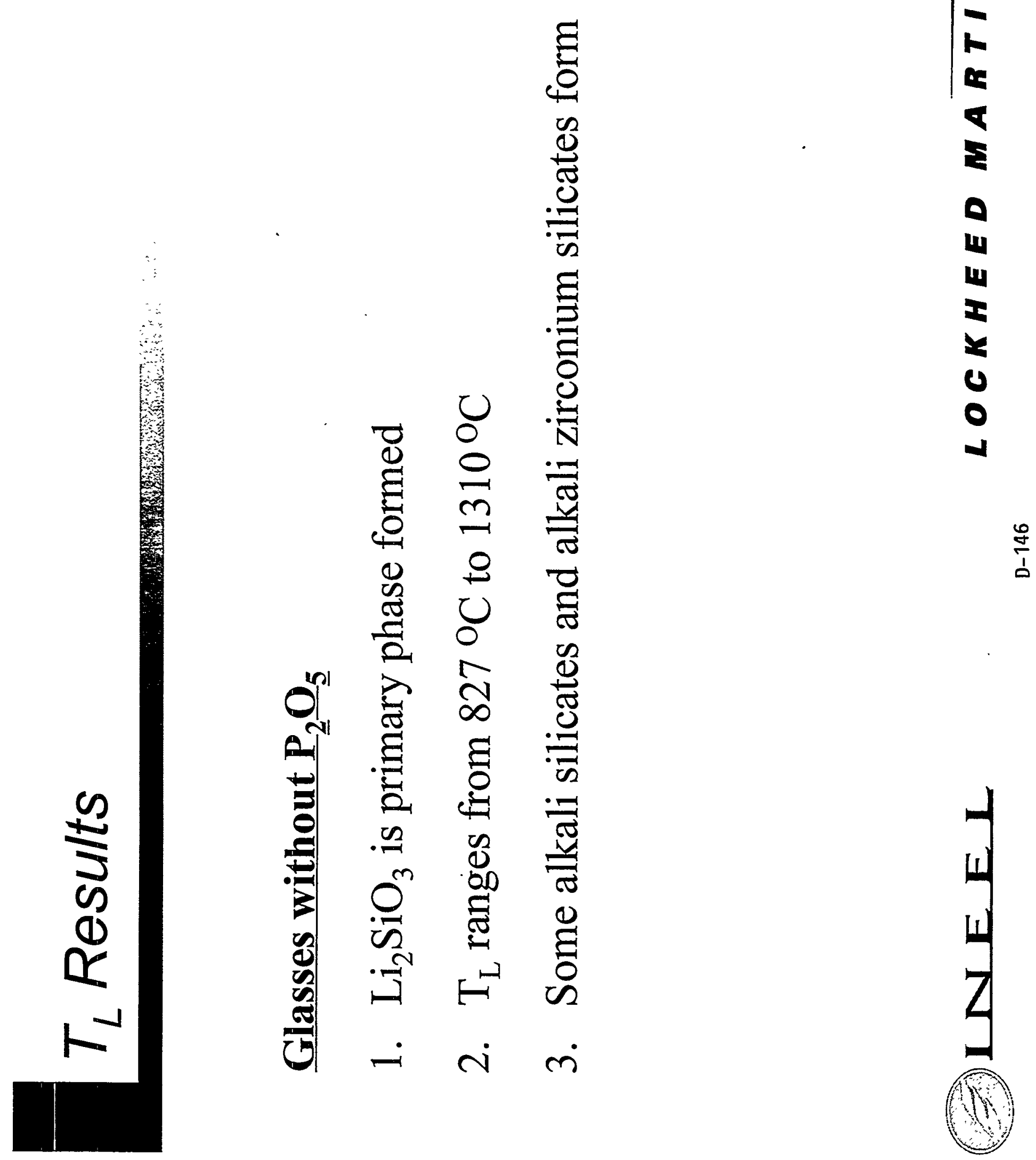




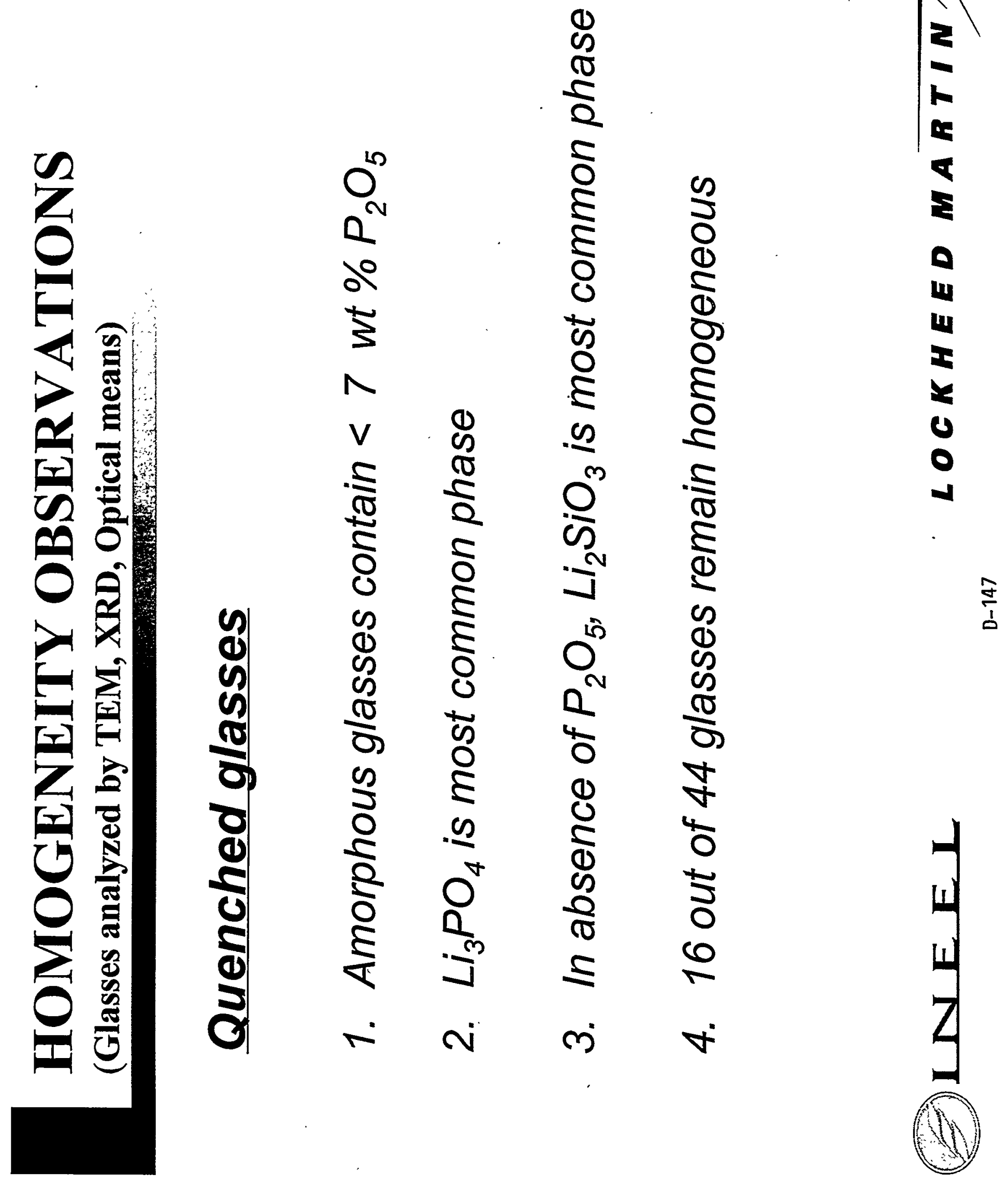



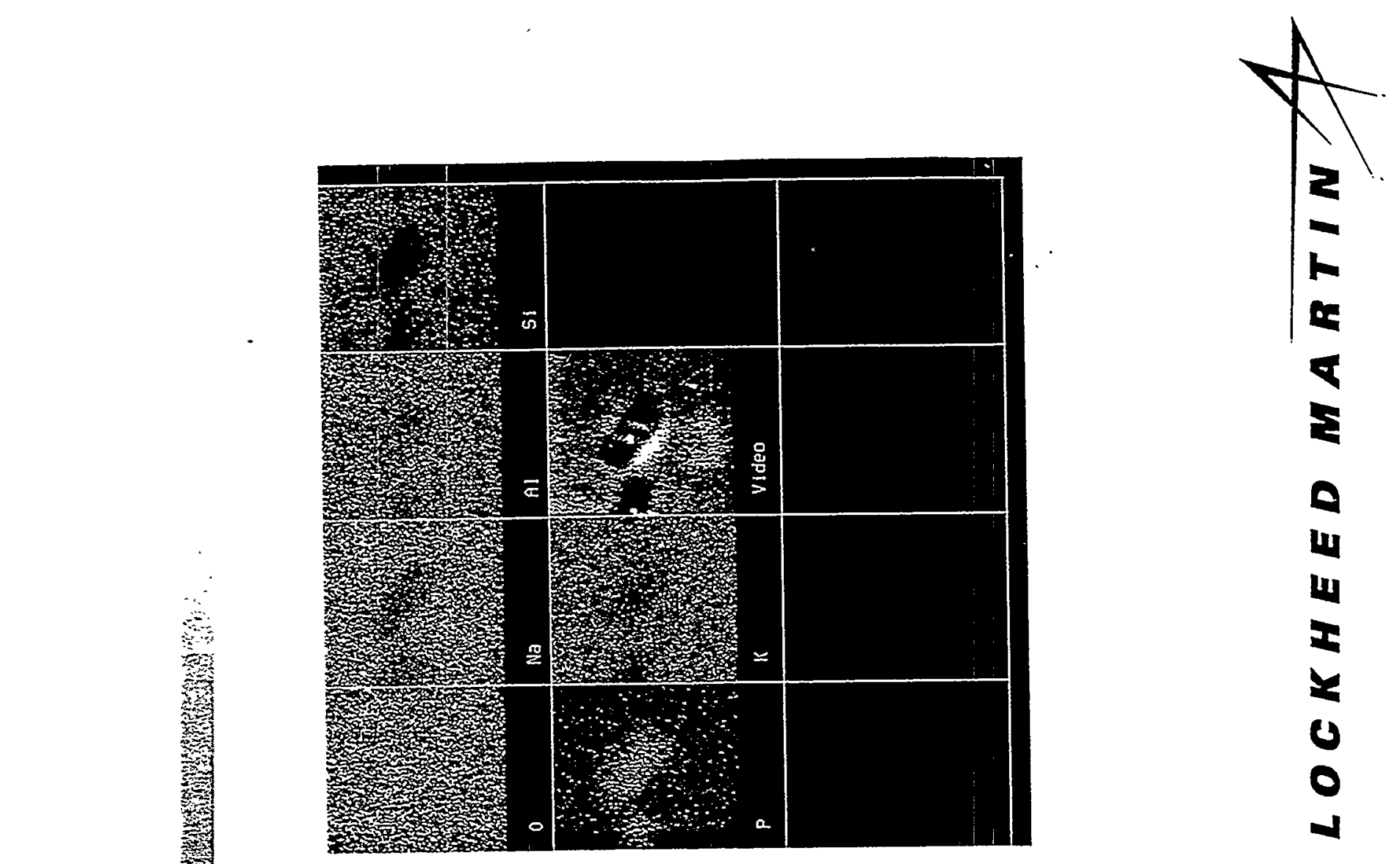

$\frac{\infty}{\stackrel{D}{\sigma}}$
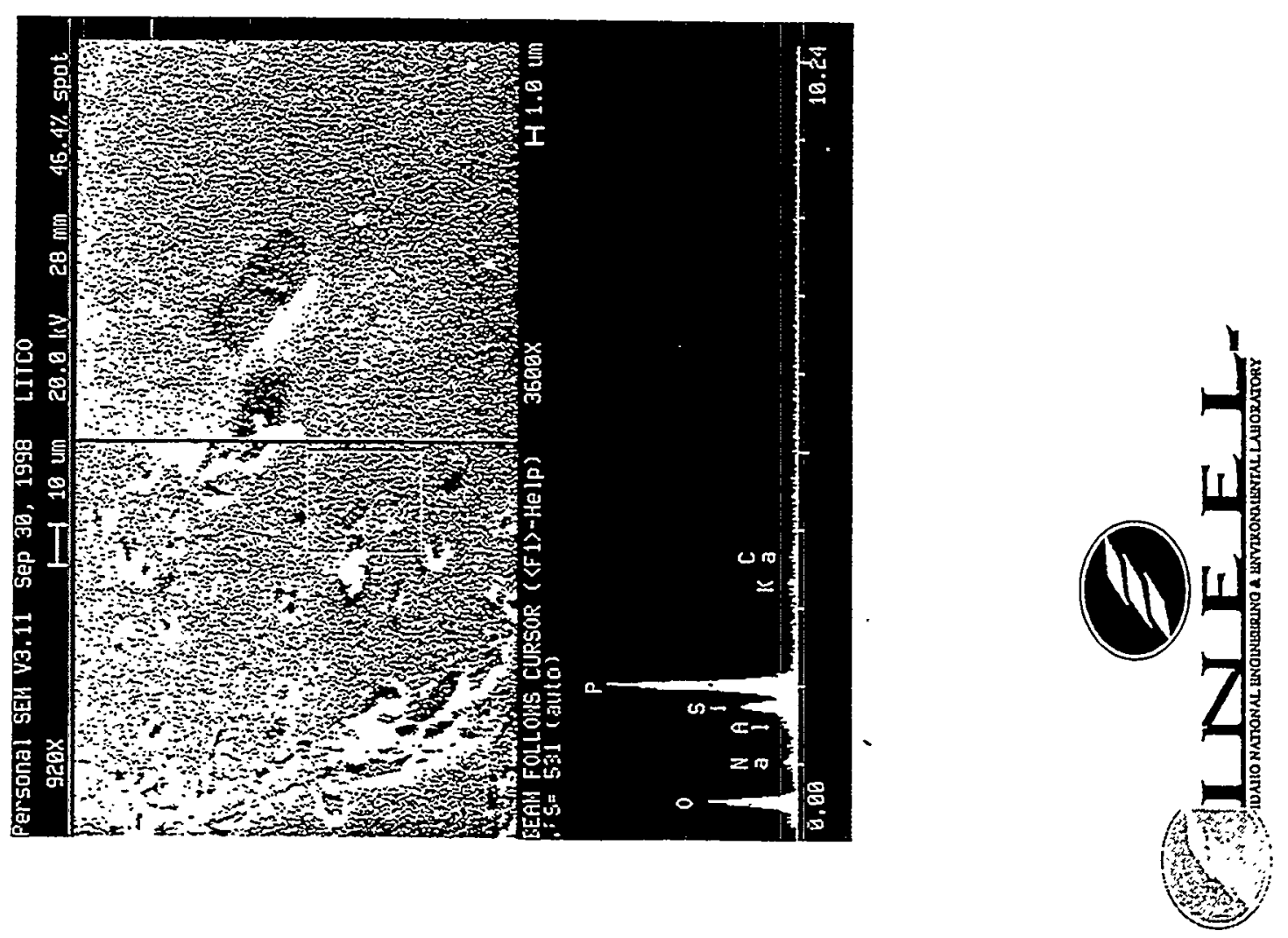

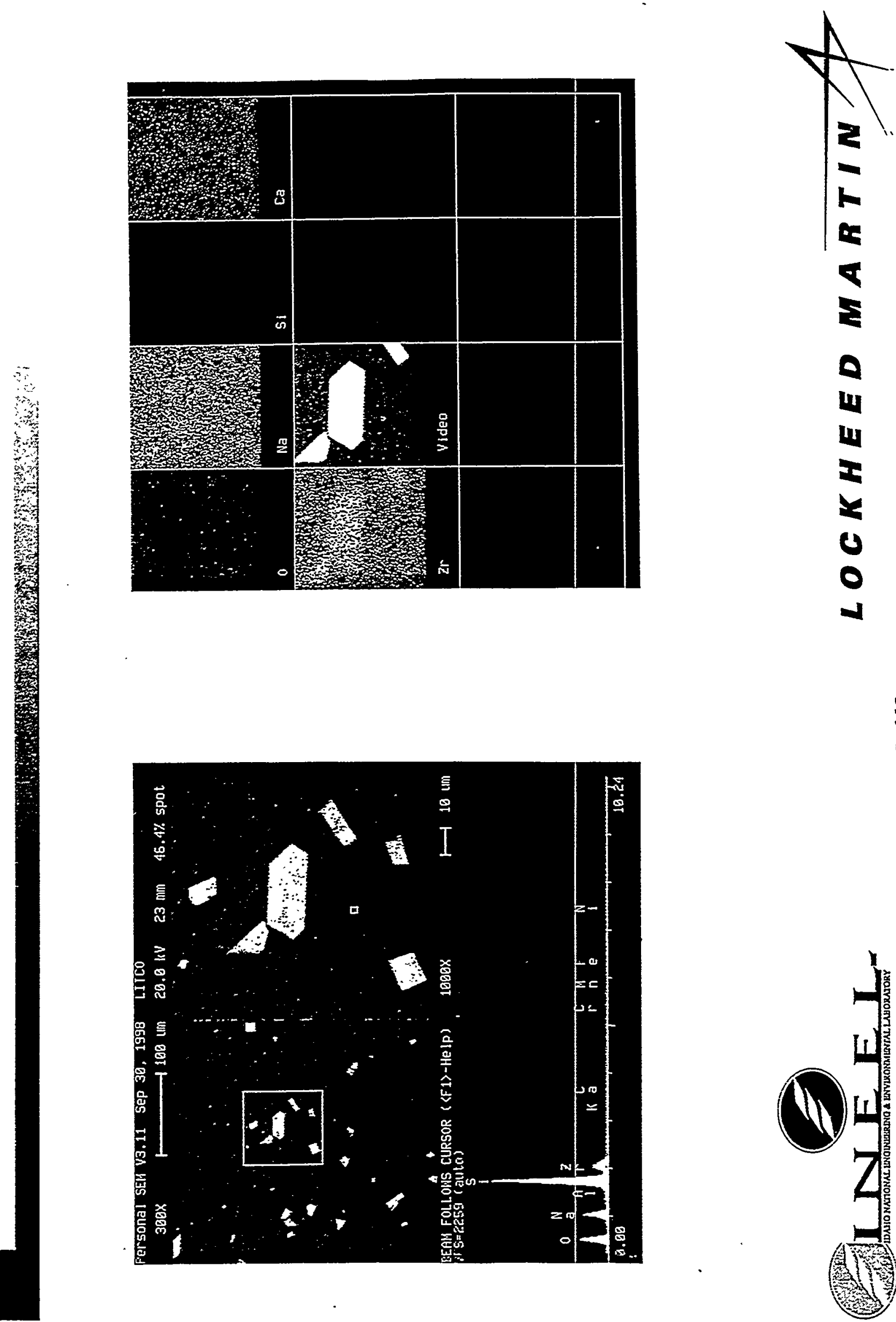

$\frac{g}{d}$

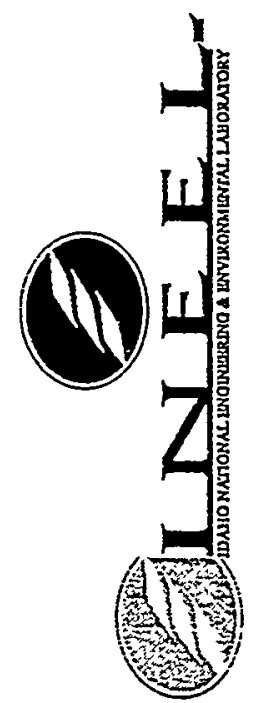




\section{HOMOGENEITY OBSERVATIONS}

(Glasses analyzed by TEM, XRD, Optical means)

Glasses cooled at canister centerline rate

1. Only two of eight glasses remained homogeneous

2. Homogeneous glasses have $<1.25$ wt $\% \mathrm{P}_{2} \mathrm{O}_{5}$

3. $\mathrm{Li}_{3} \mathrm{PO}_{4}$ is most common crystalline phase to form 


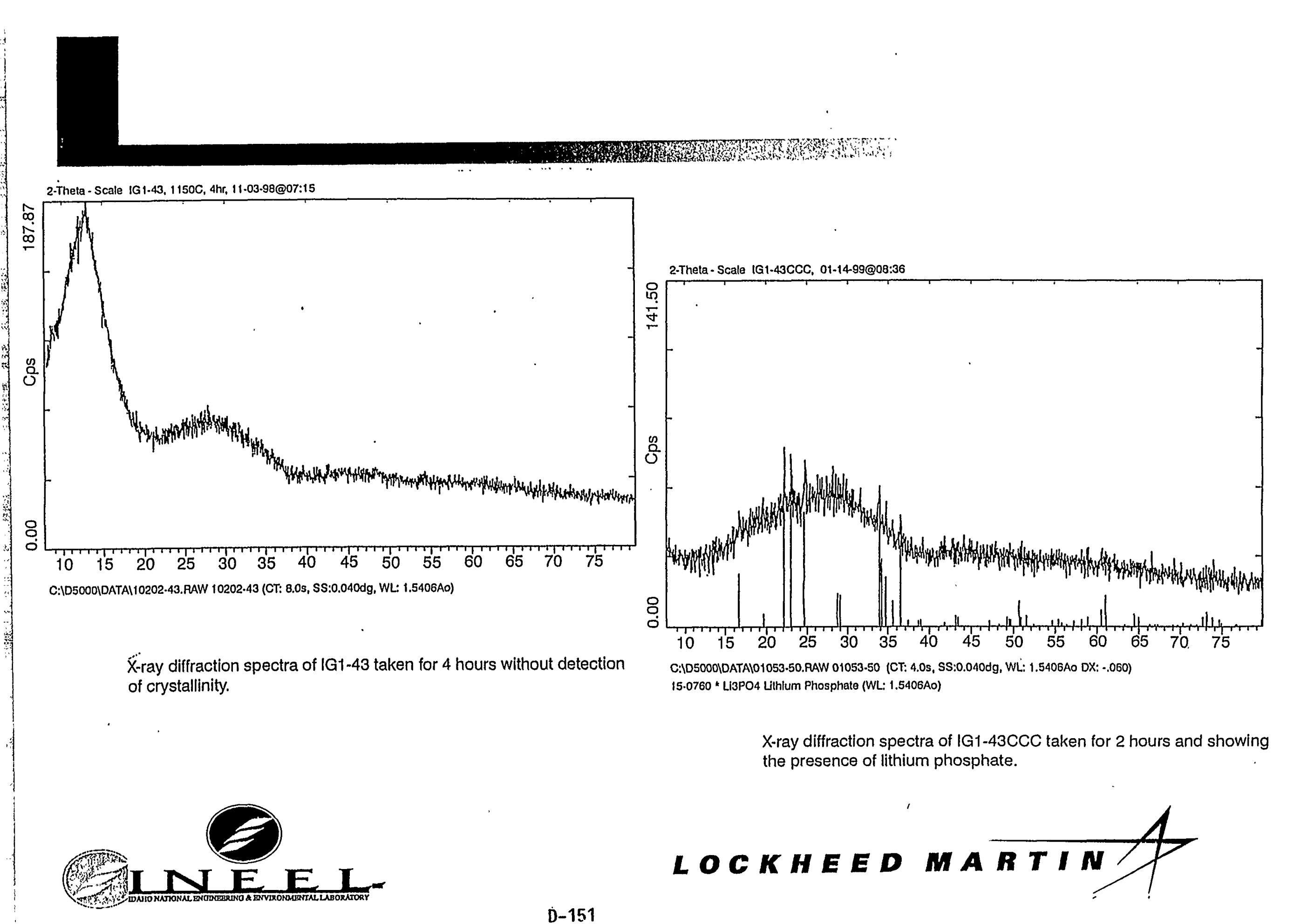




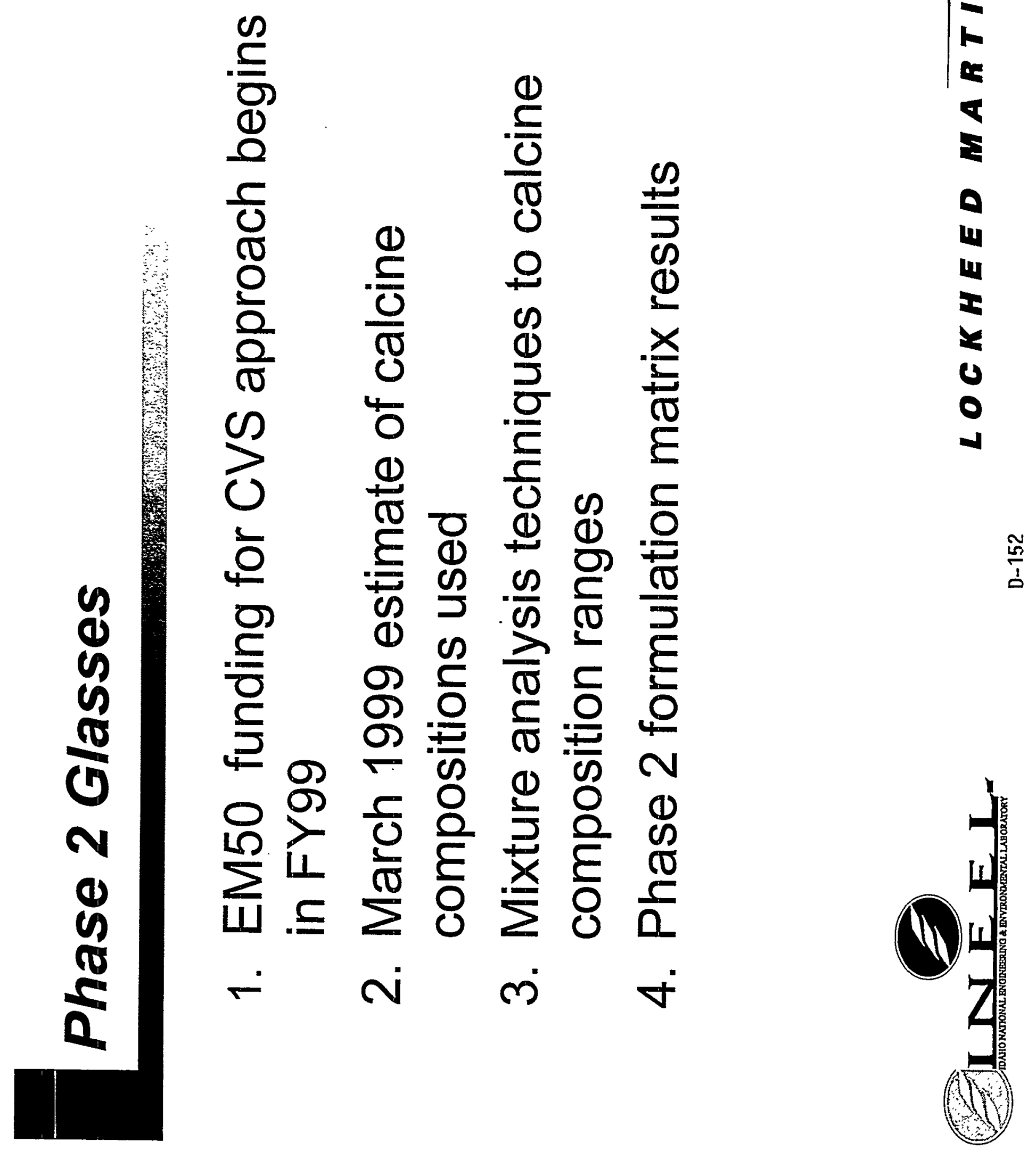




\section{Characterization Protocol}

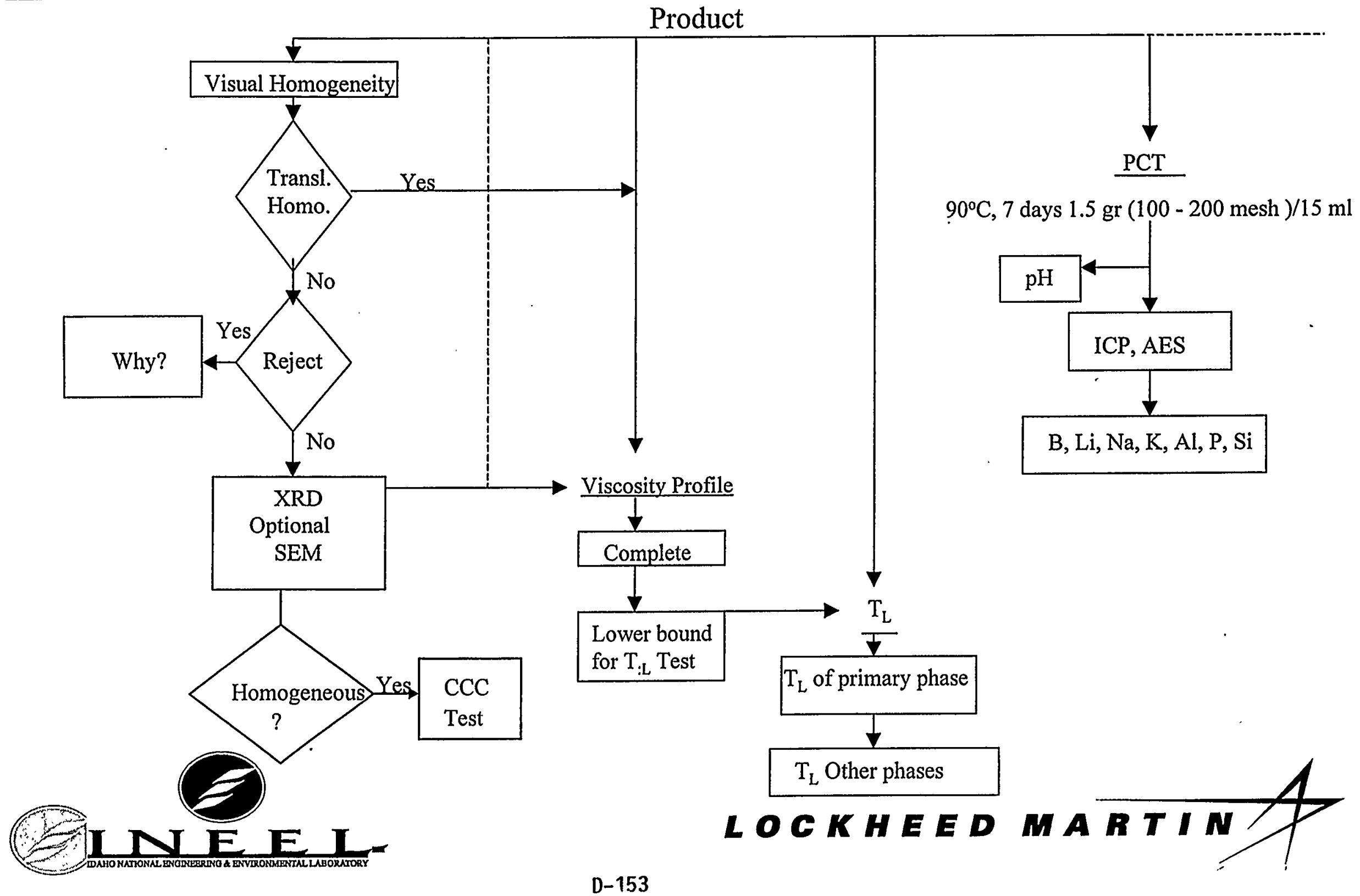



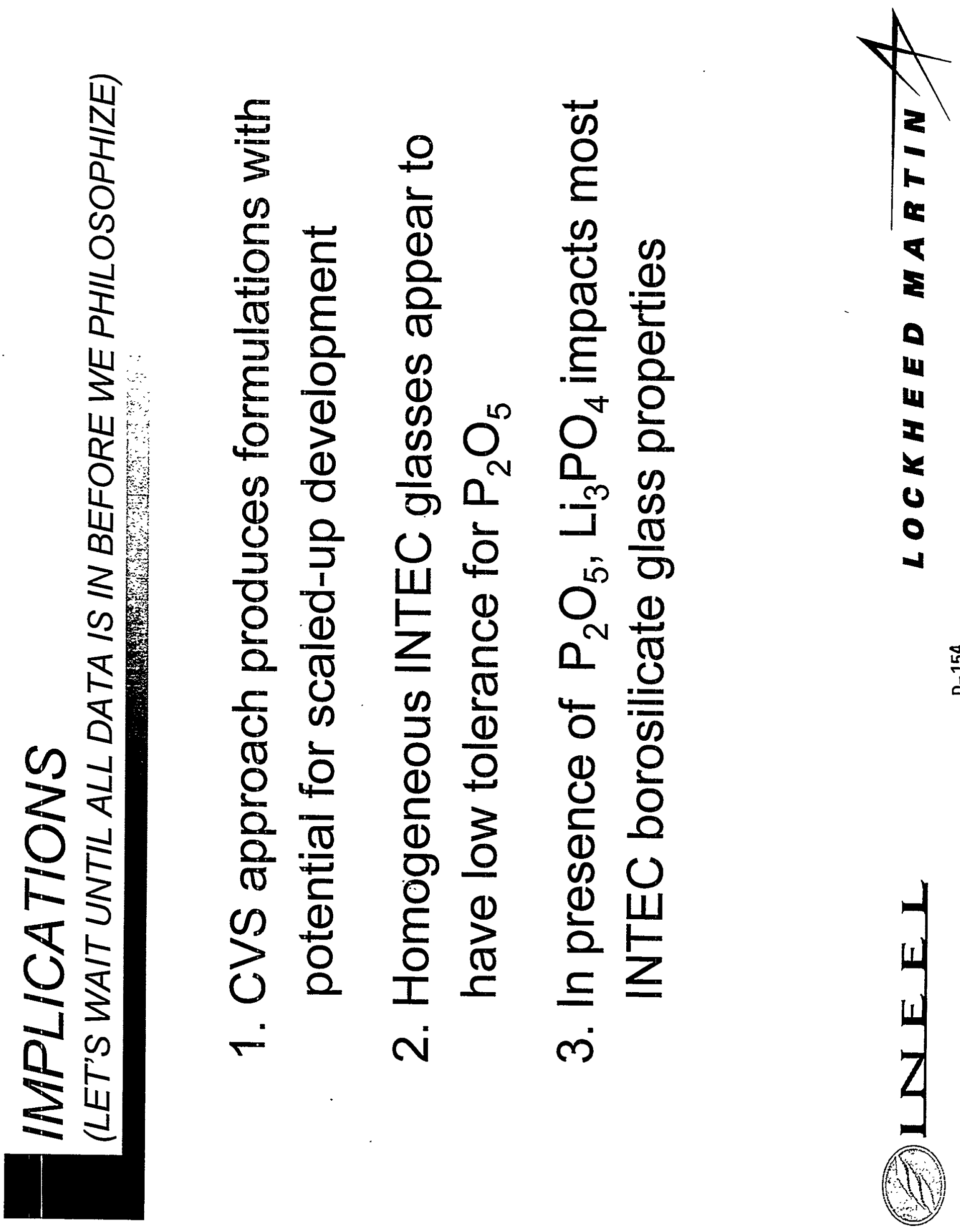


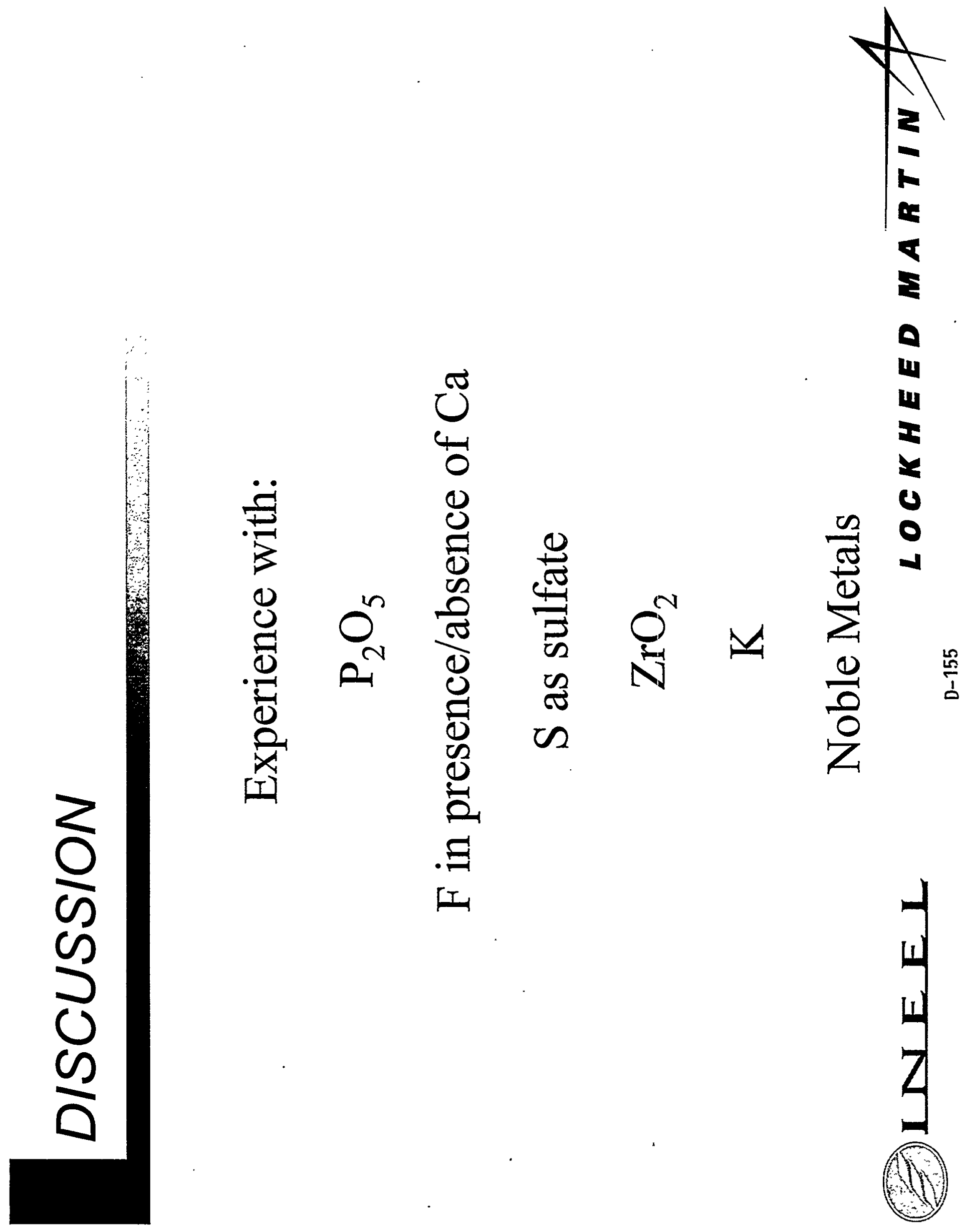



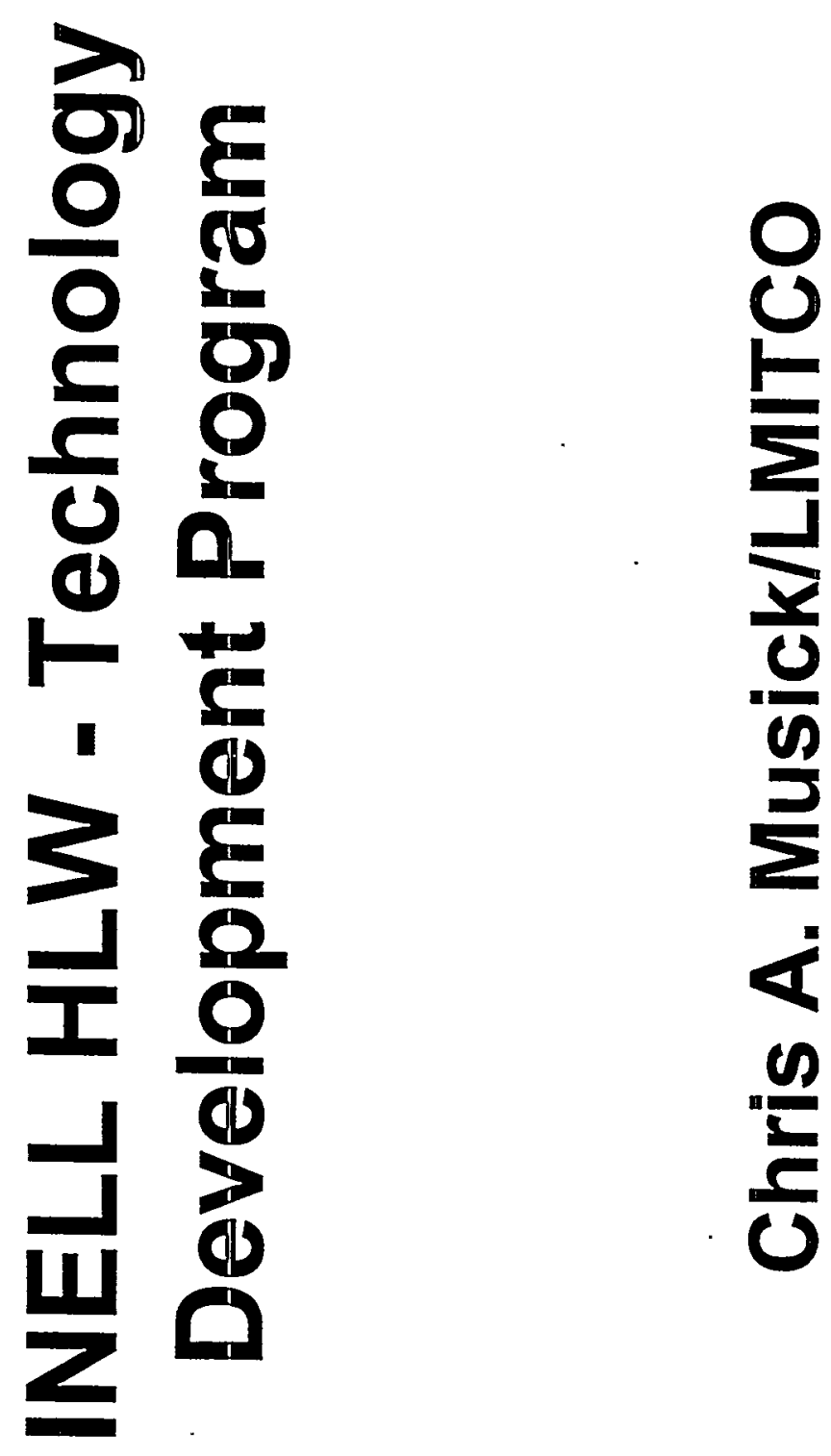

$\frac{n}{5}$
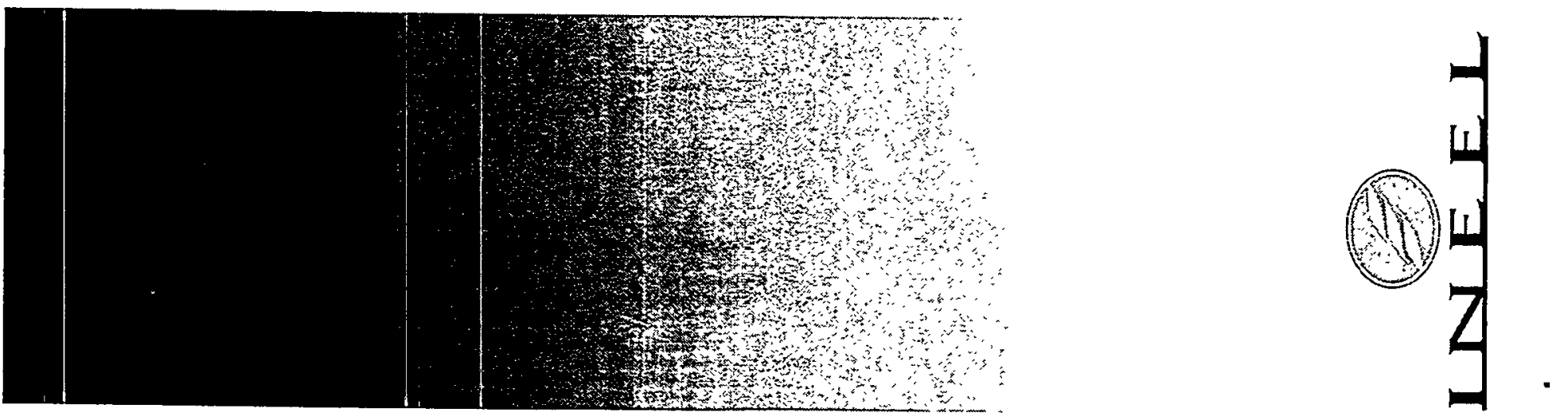


\section{WHAT IS SEPARATIONS:}

- Chemical Process that dissolves existing and future calcines to separate the radioactive elements

- Processes that removes actinides, strontium, cesium, and technetium into a High Activity Waste (HAW) fraction. The HAW fraction also includes undissolved solids from calcine dissolution.

- The remaining waste is considered Low Activity Waste (LAW), which will be immobilized via Grout. 
975

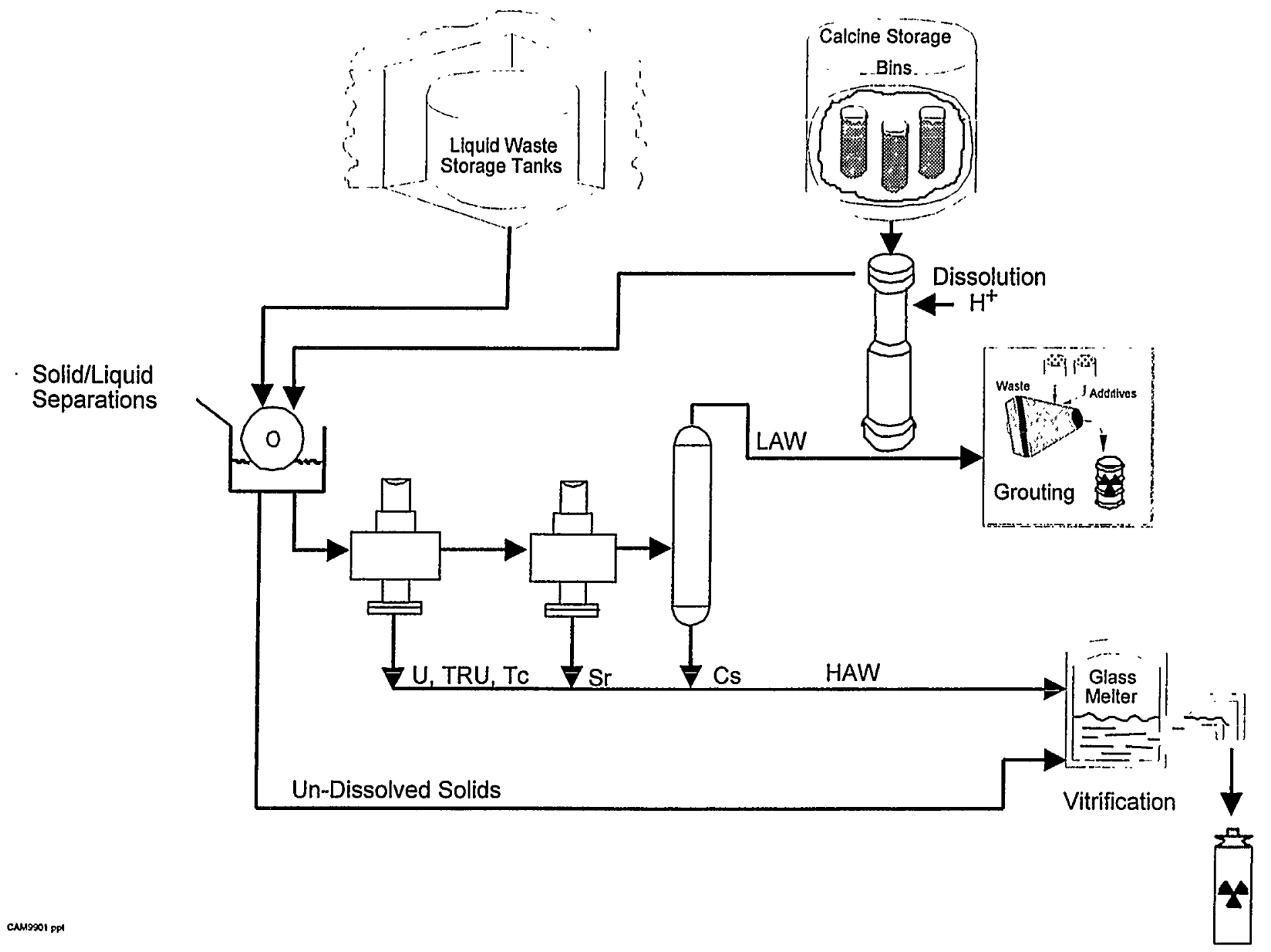




\section{HAW Vitrification Off-Gas System}

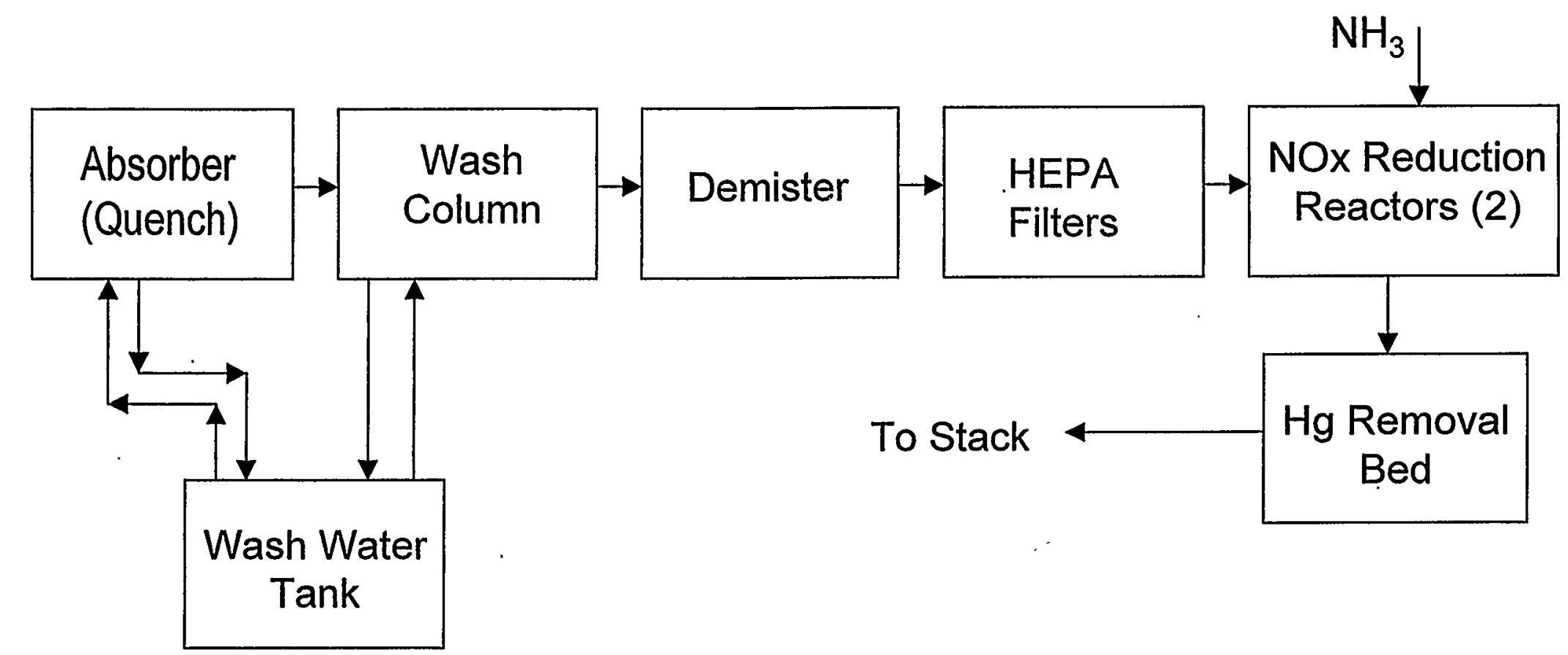




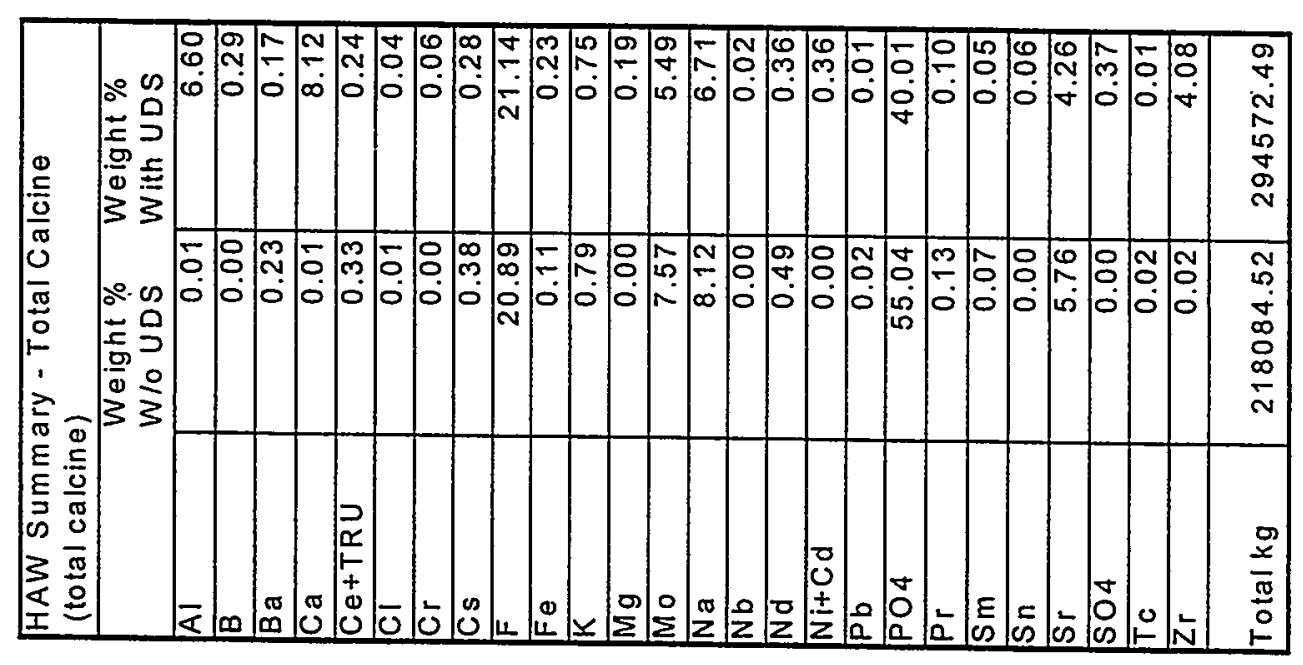

$\frac{8}{6}$ 


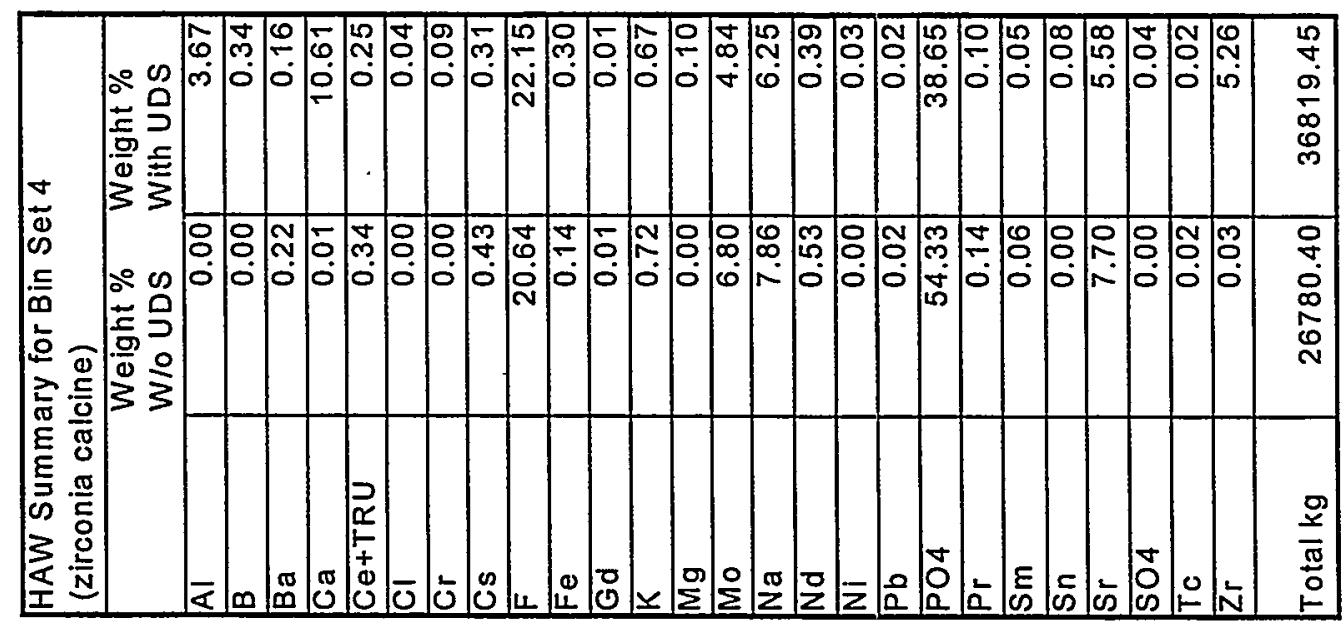

$\frac{5}{1}$ 


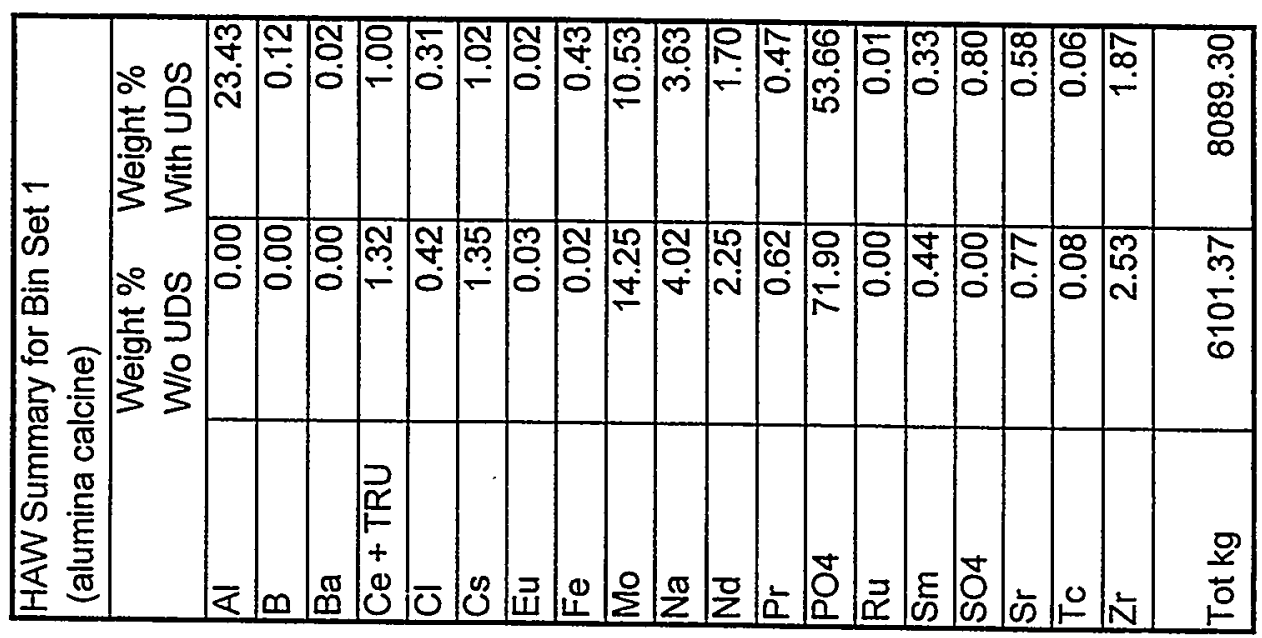

$\frac{1}{1}$

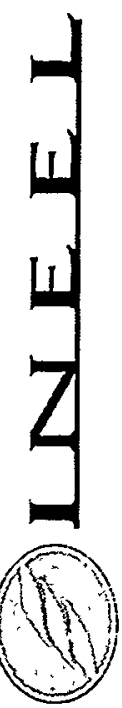




\section{High Activity Waste Composition - SBW - HAW}

\begin{tabular}{|c|c|c|}
\hline \multicolumn{3}{|c|}{ HAW Summary - SBW } \\
\hline \multicolumn{3}{|c|}{$\begin{array}{c}\text { w/o UDS } \\
\text { wt } \%\end{array}$} \\
\hline Al & $\begin{array}{c}\text { w/ UDS } \\
\text { wt } \%\end{array}$ \\
\hline $\mathrm{B}$ & 0.01 & 1.17 \\
\hline $\mathrm{Ba}$ & 0.10 & 1.94 \\
\hline $\mathrm{Ca}$ & 0.00 & 0.05 \\
\hline $\mathrm{Cd}+\mathrm{Ni}$ & & 1.05 \\
\hline $\mathrm{Ce}+\mathrm{TRU}$ & 0.18 & 0.09 \\
\hline $\mathrm{Cl}$ & 0.08 & 1.81 \\
\hline $\mathrm{Cr}$ & & 0.15 \\
\hline $\mathrm{Cs}$ & 0.13 & 0.07 \\
\hline $\mathrm{F}$ & 0.00 & 1.73 \\
\hline $\mathrm{Fe}$ & 0.10 & 1.67 \\
\hline $\mathrm{K}$ & 22.04 & 12.36 \\
\hline $\mathrm{Mg}$ & & 1.05 \\
\hline $\mathrm{Mn}$ & & 0.25 \\
\hline $\mathrm{Mo}$ & 5.43 & 3.84 \\
\hline $\mathrm{Na}$ & 16.09 & 11.09 \\
\hline $\mathrm{Nd}$ & 0.21 & 0.11 \\
\hline $\mathrm{Pb}$ & 0.60 & 0.41 \\
\hline $\mathrm{PO} 4$ & 31.08 & 24.70 \\
\hline $\mathrm{Ru}$ & & 1.05 \\
\hline $\mathrm{Si}$ & & 2.65 \\
\hline $\mathrm{SO} 4$ & & 9.59 \\
\hline $\mathrm{Zr}$ & 23.77 & 21.27 \\
\hline $\mathrm{Tot} \mathrm{kg}$ & 10286.70 & 20023.34 \\
\hline & & \\
\hline
\end{tabular}




\section{What is Direct Vitrification:}

- No dissolution or radionuclide partitioning prior to vitrification.

- Retrieve and directly vitrify the calcine ad liquid sodium bearing waste.

- Direct Vitrification of the liquid SBW may include evaporation/denitraiton

- Direct Vitrification of calcine may include minor pretreatment steps (i.,e. mixing, etc.) for waste qualification.

@NEEL 


\section{Direct Vitrification}

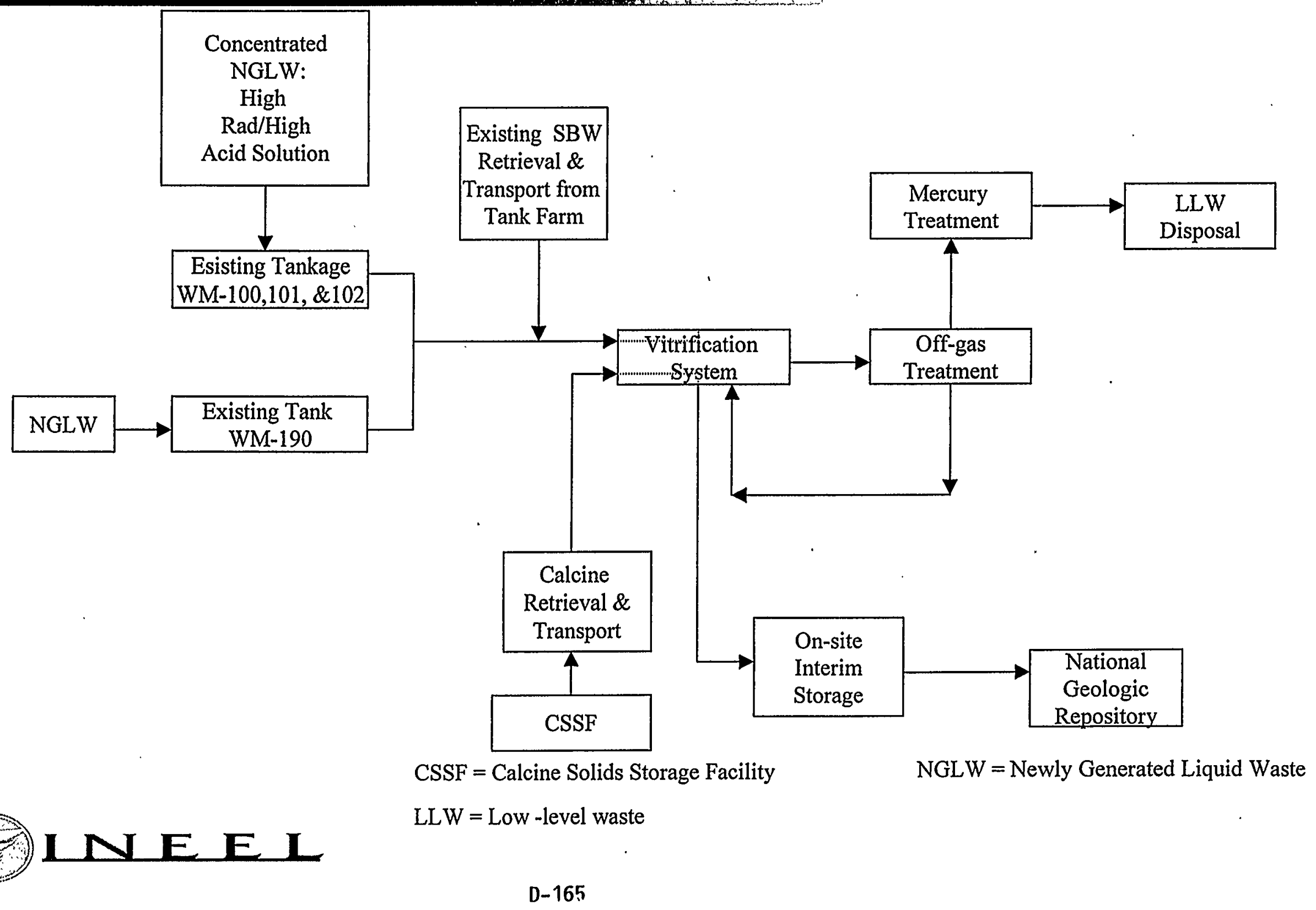




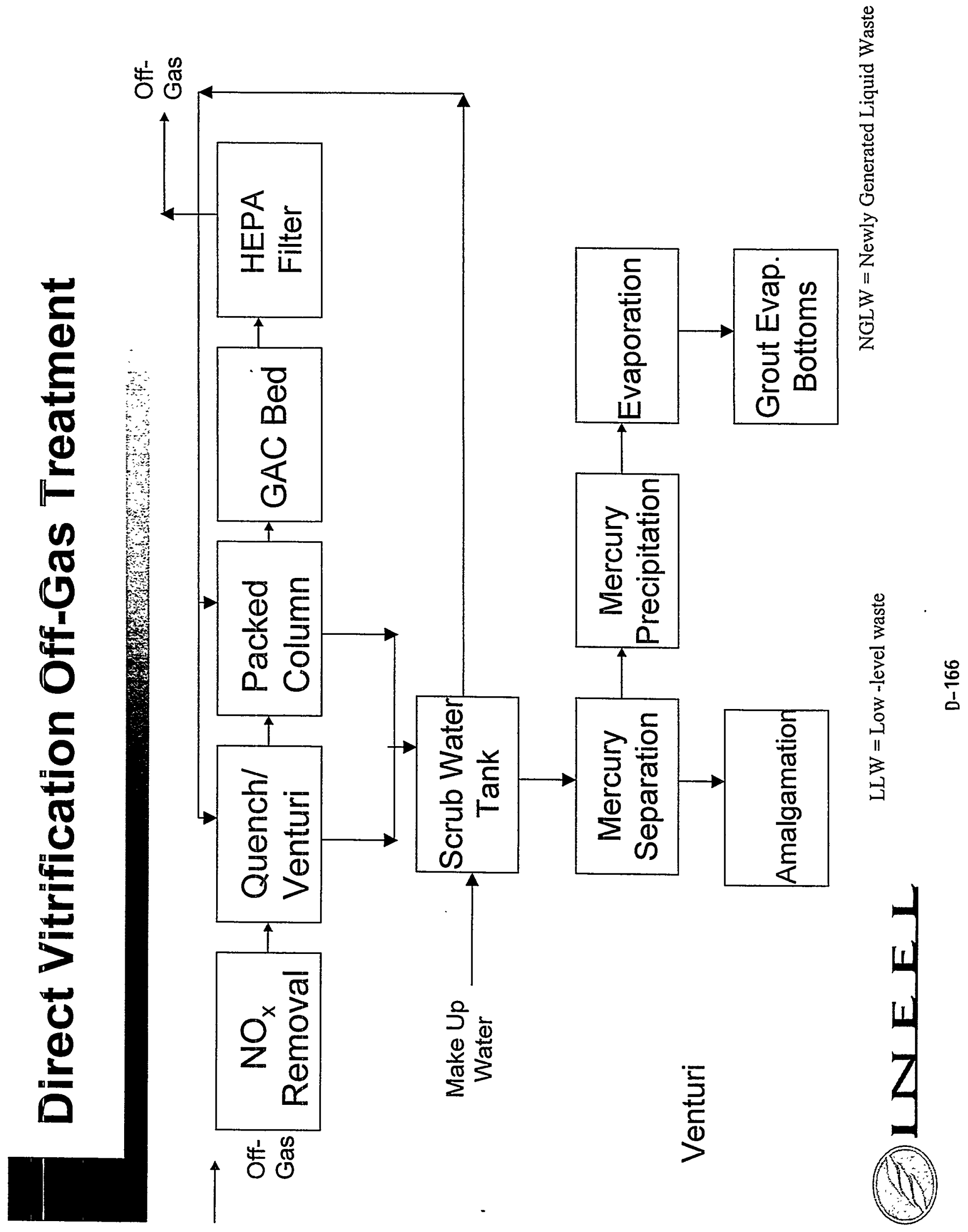




\section{High Level Waste Compositions of Calcine and SBW}

\begin{tabular}{|c|c|c|c|c|c|c|c|}
\hline Element & B inset \# 1 & B inset \#2 & B inset \# 3 & B inset \#4 & B inset \# 5 & B inset \# 6 & S B W \\
\hline $\mathrm{Ni}$ & 0.0 & 0.0 & 0.0 & 0.1 & 4.00 & 1.75 & 0.60 \\
\hline $\mathrm{Pb}$ & 0.0 & 0.0 & 0.0 & 0.0 & 0.00 & 0.00 & 0.40 \\
\hline $\mathrm{Pd}$ & 0.0 & 0.0 & 0.0 & 0.0 & 0.00 & 0.00 & 0.00 \\
\hline $\mathrm{PO}_{4}$ & 2.0 & 0.4 & 1.2 & 0.0 & 0.24 & 0.54 & 2.23 \\
\hline $\operatorname{Pr}$ & 0.0 & 0.0 & 0.0 & 0.0 & 0.01 & 0.01 & 0.00 \\
\hline $\mathrm{R} \mathrm{b}$ & 0.0 & 0.0 & 0.0 & 0.0 & 0.00 & 0.00 & 0.00 \\
\hline $\mathrm{Rh}$ & 0.0 & 0.0 & 0.0 & 0.0 & 0.00 & 0.00 & 0.00 \\
\hline $\mathrm{Ru}$ & 0.0 & 0.0 & 0.0 & 0.0 & 0.01 & 0.01 & 0.05 \\
\hline $\mathrm{Si}$ & 0.0 & 0.0 & 0.0 & 0.0 & 0.00 & 0.00 & 0.12 \\
\hline $\mathrm{Sm}$ & 0.0 & 0.0 & 0.0 & 0.0 & 0.00 & 0.00 & 0.00 \\
\hline Sn & 0.0 & 0.2 & 0.3 & 0.2 & 0.21 & 0.07 & 0.02 \\
\hline $\mathrm{SO}_{4}$ & 3.0 & 0.6 & 0.6 & 0.1 & 2.72 & 2.19 & 6.24 \\
\hline $\mathrm{Sr}$ & 0.0 & 0.2 & 0.3 & 0.3 & 0.35 & 0.13 & 0.00 \\
\hline $\mathrm{Tc}$ & 0.0 & 0.0 & 0.0 & 0.0 & 0.01 & 0.00 & 0.00 \\
\hline $\mathrm{Te}$ & 0.0 & 0.0 & 0.0 & 0.0 & 0.00 & 0.00 & 0.00 \\
\hline $\mathrm{U}$ & 0.0 & 0.0 & 0.0 & 0.0 & 0.02 & 0.16 & 0.00 \\
\hline $\mathrm{Y}$ & 0.0 & 0.0 & 0.0 & 0.0 & 0.01 & 0.00 & 0.00 \\
\hline $\mathrm{Zr}$ & 0.1 & 14.3 & 19.0 & 18.1 & 13.79 & 4.10 & 1.03 \\
\hline Total & 100.0 & 100.0 & 100.0 & 100.0 & 100.00 & 100.00 & 100.00 \\
\hline $\begin{array}{l}\text { Total } \\
(\mathrm{kg})\end{array}$ & $9.71 \mathrm{E}+04$ & $7.58 \mathrm{E}+05$ & $1.08 \mathrm{E}+06$ & $5.02 \mathrm{E}+05$ & $1.03 E+06$ & $3.57 \mathrm{E}+05$ & $2.76 \mathrm{E}+05$ \\
\hline
\end{tabular}




\title{
Melter Conference Off-Gas Monitoring and Control
}

\author{
Sam Ashworth/COGEMA \\ Technologies/LMITCO Augusta, GA, \\ May 4-7, 1999
}




\section{AGENDA}

- Background

- Control and Treatment of Volatile Components (e.g., Hg, Organics, Tc)

- Regulatory Compliance

- Wastewater Treatment

- Uncertainties/Current Development at NWCF 


\section{Background}

- NWCF at INEEL calciner currently operating. Future operation to meet incinerator requirements (e.g., MACT)

- Future design/operations anticipate thermal systems like vitrification, afterburners and new calciners 


\section{Background}

- INEEL has generated large quantities of highlevel wastes that have been in storage at the INTEC for many years

- The DOE is preparing HLW Environmental Impact Statement (EIS) to identify alternative management strategies for the high-level waste 


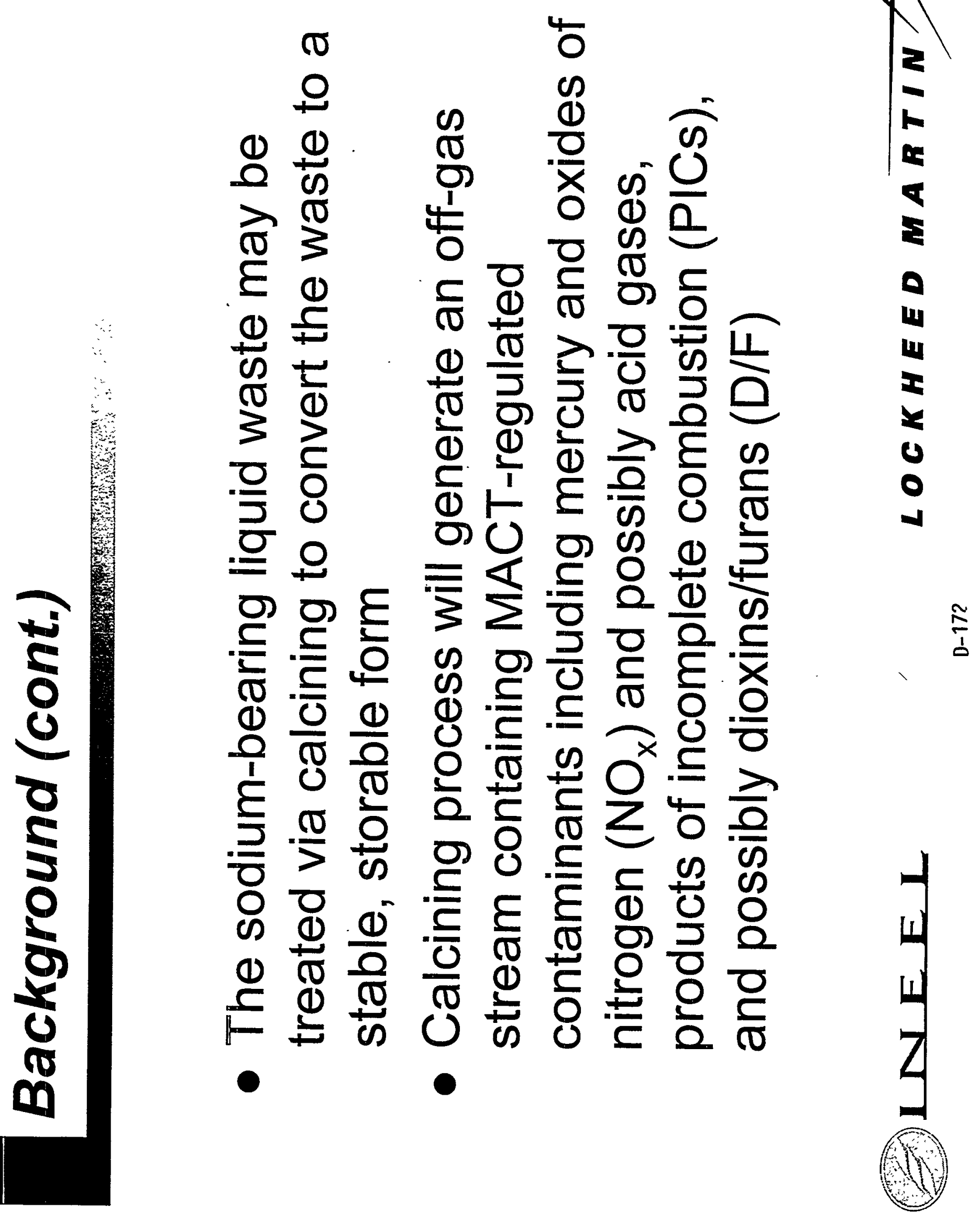




\section{Background (cont.)}

- The feed from the tank farms to the calciner has significant mercury present from past operations

- The EIS has several options including direct vitrification of calcine

- Process design for this will have some unique requirements based on INEEL wastes and environmental regulatory requirements 


\section{Control and Treatment of Volatile Comoonents (cont)}

- For generic thermal system, what constitutes offgas components?

- Potentials include

$\bullet \mathrm{Hg}$

- Entrained radionuclide/non-rad particles

- Volatile Tc, Cs, Ru, I

- $\mathrm{HNO}_{3} / \mathrm{NOx}, \mathrm{HCL} / \mathrm{Cl}_{2}$ 


\section{Control and Treatment of Volatile}

\section{Components (cont)}

Oganics

- Solvent decomposition Products (e.g., TBP)

$\bullet \mathrm{D} / \mathrm{F}$

-PCB

-SVOC

$-\mathrm{VOC}$

-PAH

$\mathrm{HF} / \mathrm{F}_{2}$ 


\section{Control and Treatment of Volatile Components (cont.)}

- Materials of Construction

- Special Materials to withstand acid/HF environment and temperature

- Hastelloys, Titanium, Ceramics? 

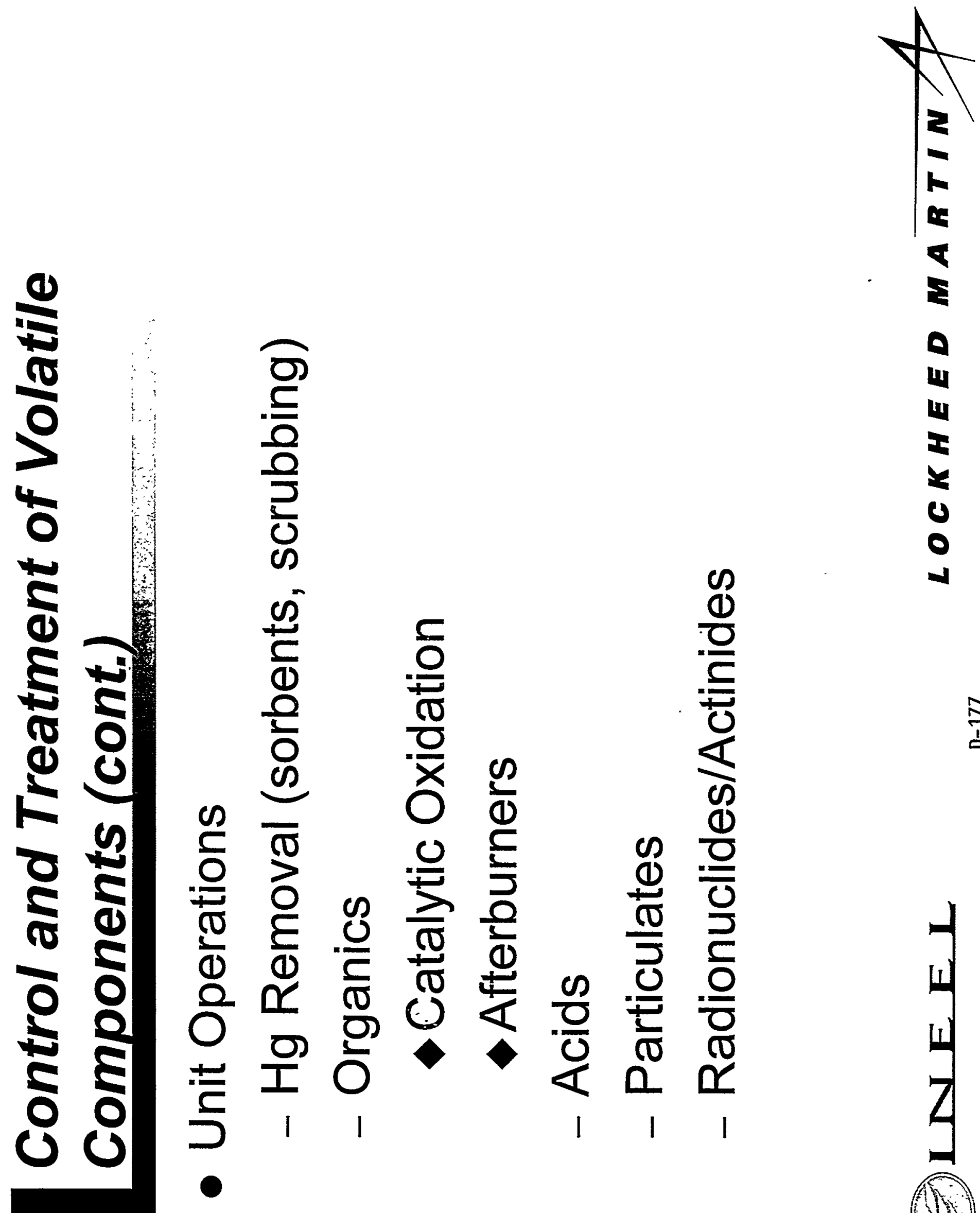

$\frac{1}{b}$

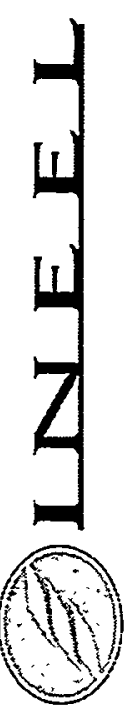




\section{Control and Treatment of Volatile Components (cont).}

- How does a typical melter impact speciation

- $\mathrm{CaF}_{2}$ (HF emissions)

- Nitrates

- Reducing or Oxidizing from melter? 


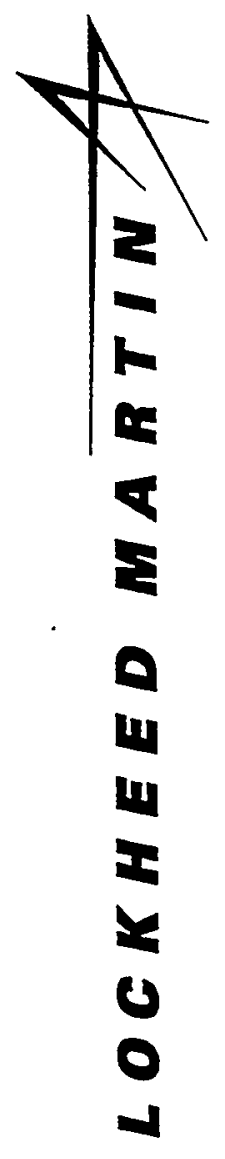

$\frac{9}{1}$
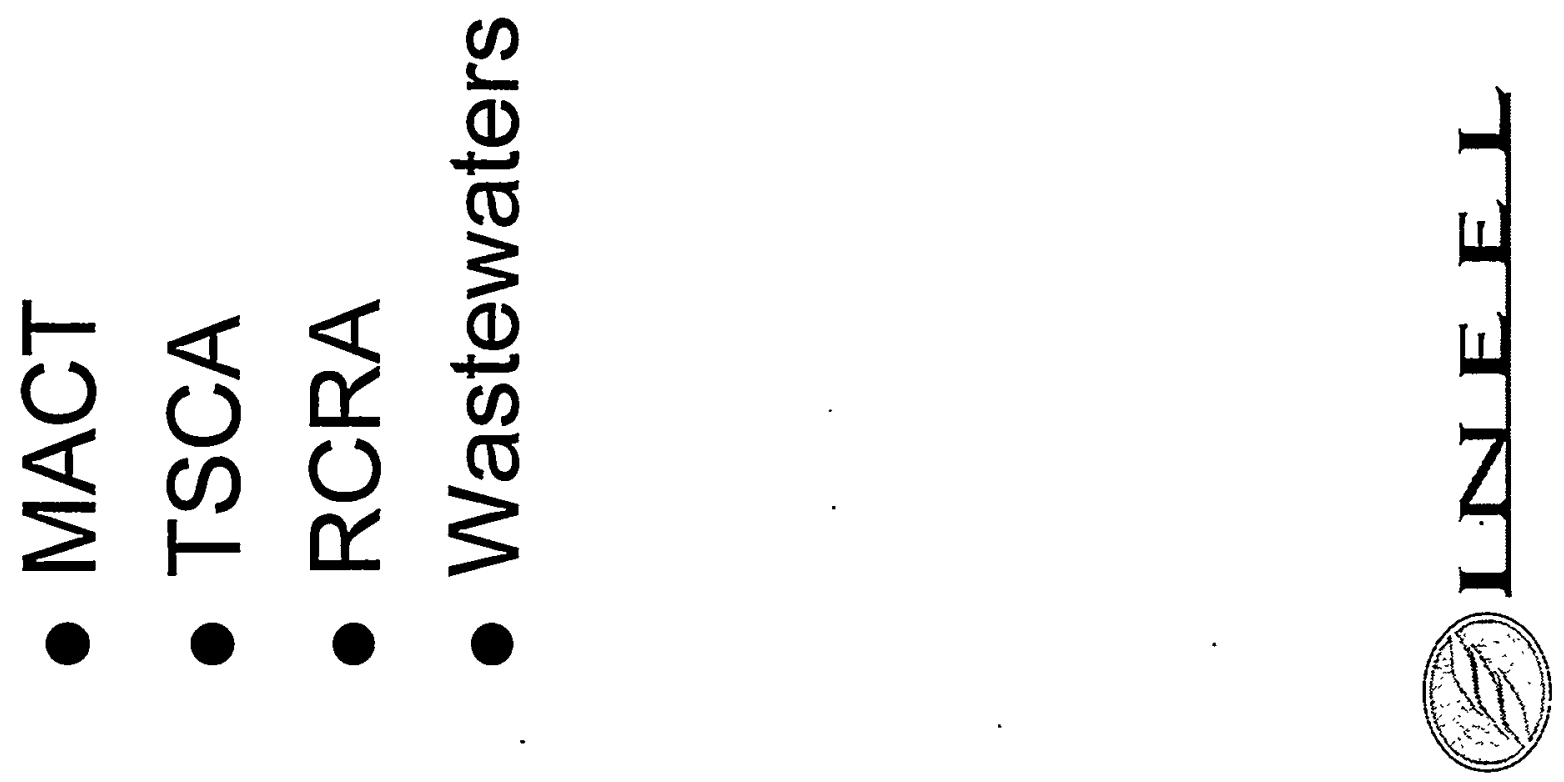


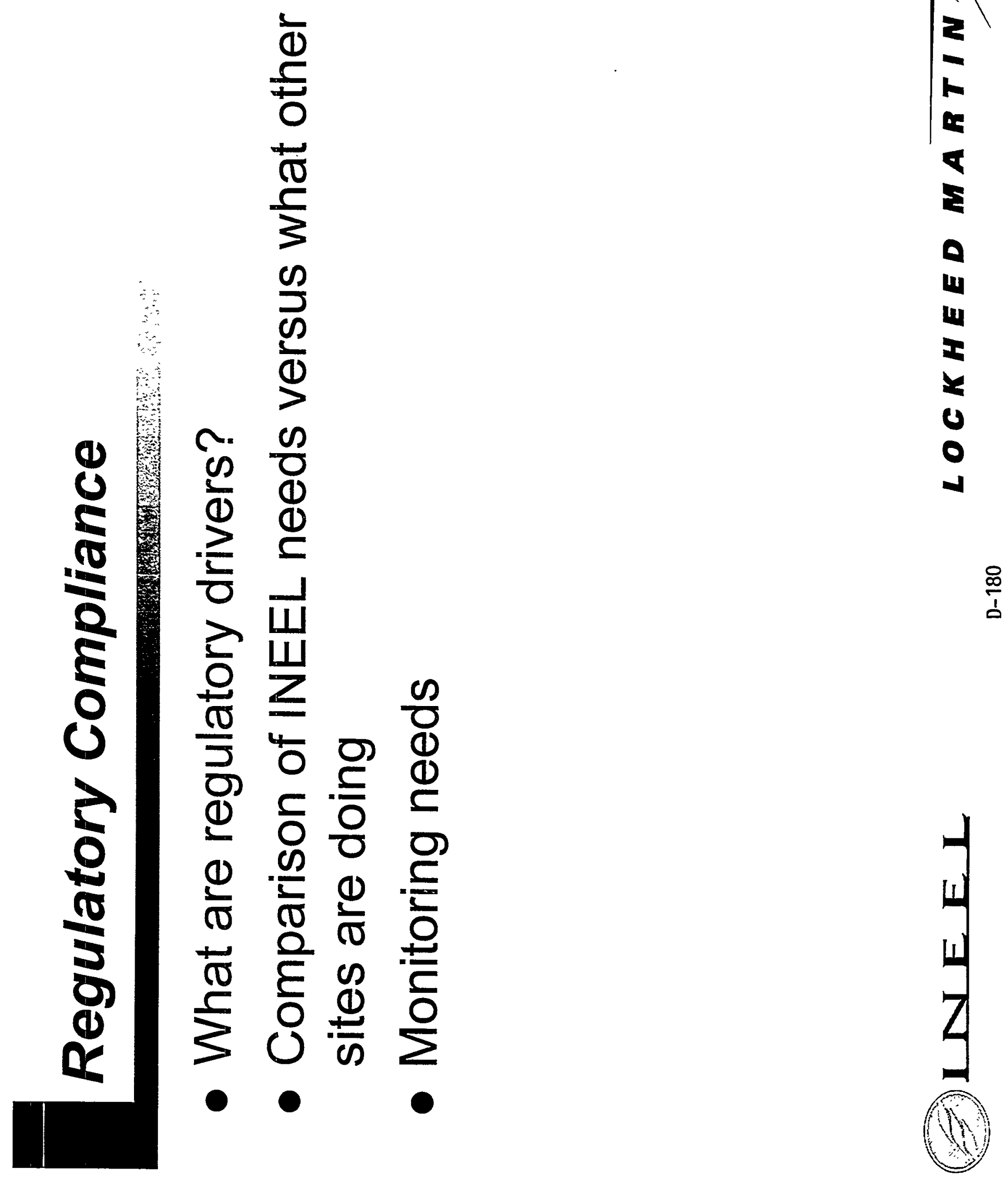




\section{Regulatory Compliance}

\section{MACT}

- The proposed, revised technical standards would limit emissions of dioxins and furans, mercury, semi-volatile metals (cadmium and lead), lowvolatile metals (arsenic, beryllium, chromium, and antimony), particulate matter, acid gas emissions (hydrochloric acid and chlorine), hydrocarbons, and carbon monoxide. 


\section{Regulatory Compliance (cont) MACT}

- Under this proposed rule, continuous emissions monitors (CEMs) would be required for particulate matter and mercury. Prior to this rule, CEMs were required to be installed at these facilities for only carbon monoxide, total hydrocarbons and oxygen 


\section{Regulatory Compliance (cont)}

MACT

- This proposed rule would apply to hazardous waste incinerators, cement kilns, and lightweight aggregate kilns that burn hazardous waste as fuel. 


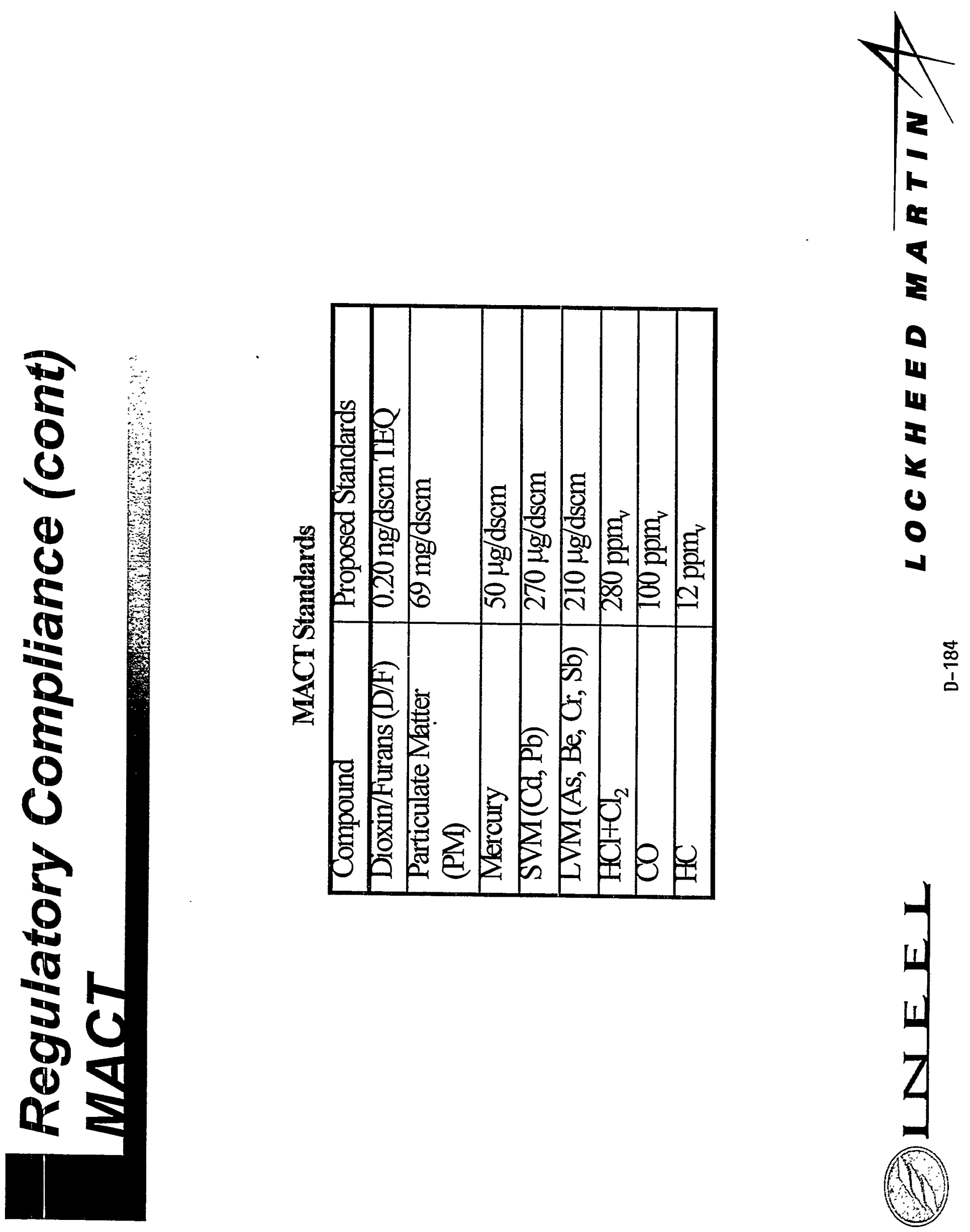




\section{Regulatory Compliance (cont)}

TSCA

- TSCA applies to PCBs and requires specific treatment or equivalent to obtain DRE of 99.9999\%

- Equivalent performance means PCB removal or destruction so PCBs cannot be quantified in residual waste or release to air, water or land 
Regulatory Compliance (cont)

RCRA

- Need to identify RCRA and CAA for continuous on-line monitoring and sample requirements.

- How have other sites approached this? 


\section{Regulatory Compliance (cont) Wastewaters}

- Wastewaters can be potentially generated that will contain radionculides, $\mathrm{Hg}, \mathrm{Tc}$, etc

- Regulatory requirements need addressing for these potential effluents 


\section{Uncertainties/Current Develonmentat NWCF}

- Potential volatile species include Tc, Cs, F, I, Hg and possibly others

- Difficult to estimate speciation for some of the volatile components

- Off-gas system may have wet process (i.e., scrubber) and will therefore involve liquid treatment 


\section{Uncertainties/Current \\ Development at NWCF (cont)}

- Studies indicate Tc follows Hg somewhat so separation difficulty likely

- In liquid process $\mathrm{HTcO}_{4}$ is volatile species anticipated

- Need thermodynamic data to estimate $\mathrm{HTcO}_{4}$ fate and transport through system (e.g., full separations) 

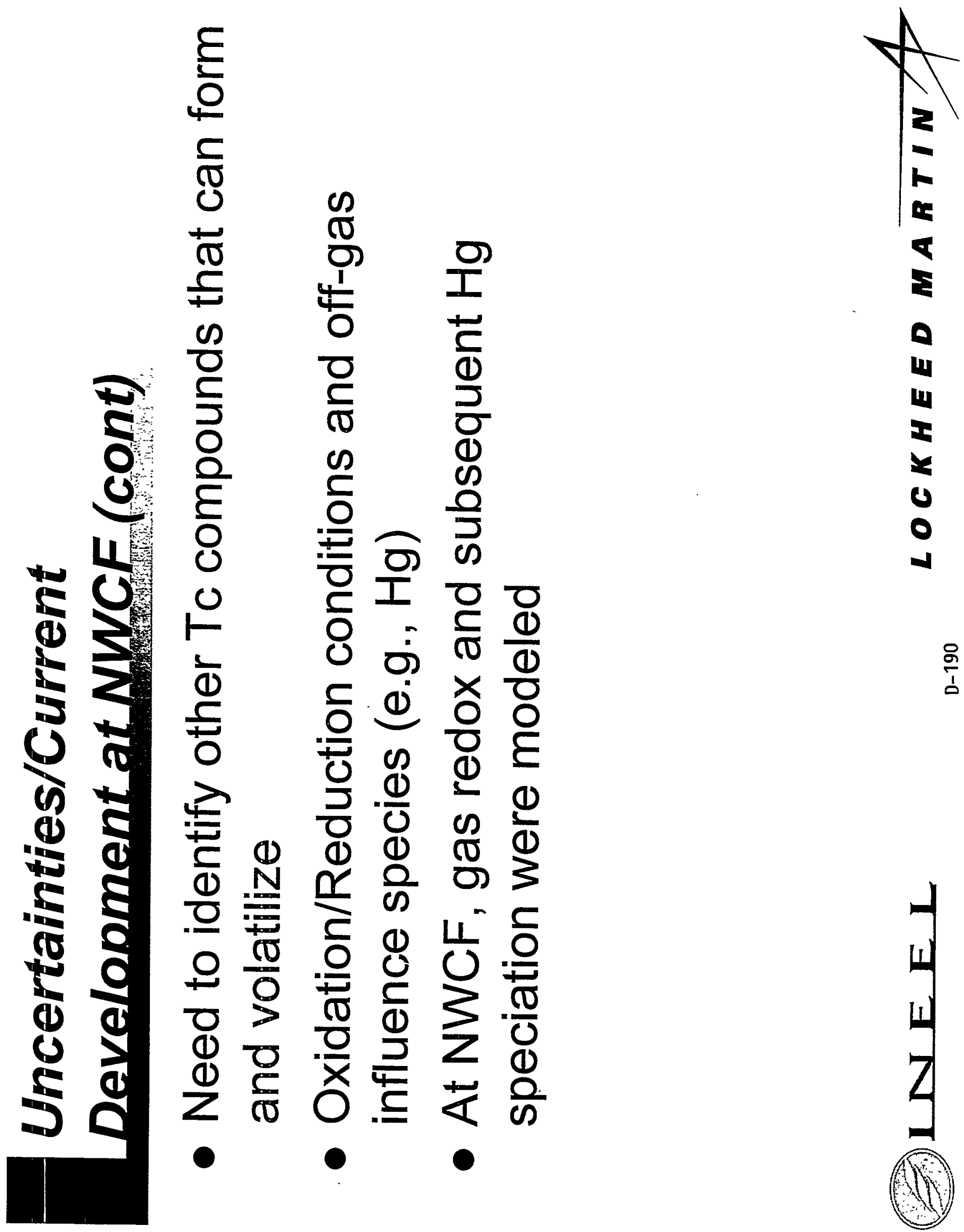

$\frac{\circ}{d}$

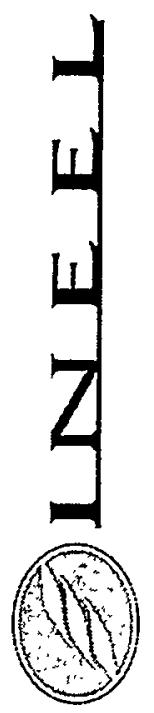




\section{Uncertainties/Current \\ Develooment at NWCF (cont)}

- NWCF gas is uncertain for gas phase reactions, thermodynamics vs kinetics

- Offgas from NWCF has $\mathrm{N}_{2} \mathrm{O}, \mathrm{NO}, \mathrm{NO}_{2}, \mathrm{O}_{2}, \mathrm{~N} 2, \mathrm{H}_{2}$, $\mathrm{CO}, \mathrm{CO}_{2}$ and $\mathrm{H}_{2} \mathrm{O}$

- Equilibrium thermodynamic computer model predicts $\mathrm{HgO}$ in this atmosphere 


\section{Uncertainties/Current Development at NWCF (cont)}

- If chlorides present, mercury prefers $\mathrm{HgCl}_{2}$ (aqueous phase) form and is also volatile

- $\mathrm{HgCl}_{2}$ can be scrubbed via wet process where $\mathrm{Hg}$ cannot

- Modeling at NWCF indicates most $\mathrm{HgCl}_{2}$ can be scrubbed by multi-stage system or modification to current equipment 


\section{Uncertainties/Current Development at NWCF (cont)}

- One goal is heel reduction of mercury in Tank Farms

- Target stream is scrub liquor that presents a large challenge to determine a process (e.g., high $\mathrm{HNO}_{3}$ )

- Only process found so far is electro-chemical unless partial neutralization 


\section{Uncertainties/Current \\ Development at NWCF (cont)}

- Other Scrub liquor treatment examined

- IX/Aqueous phase sorbents

- Membranes

- Reduction

- Cu/Zn

- Precipitation

- UV/Ti 


\section{Uncertainties/Current \\ Develooment at NWCF (cont)}

- At NWCF, $\mathrm{NO}_{\mathrm{x}}$ will impact gas-phase sorption of $\mathrm{Hg}$

- Planning testing of $\mathrm{NO}_{x}$ idizer combustion unit to remove $95+\%$ of $\mathrm{NO}_{x}$

- $\mathrm{NO}_{\mathrm{x}}$ already within permit so reason for removal is: make easier for $\mathrm{Hg}$ removal and easier to monitor $\mathrm{Hg}$ and burn organics 


\section{Uncertainties/Current Development at NWCF (cont)}

- Future thermal systems face same problem, i.e., $\mathrm{NO}_{\mathrm{x}}$ and $\mathrm{Hg}$

- Future design needs integration so that $\mathrm{Hg}$ waste form and path are defined 


\title{
Status of NWCF Offgas Monitoring
}

\author{
Andrea Chambers
}




\section{NWCF Offgas Emissions Inventory Program}

- Calciner operated under interim RCRA permit

- Now under Consent Order that requires continued emissions inventory testing with State of Idaho

- Measurements of NWCF offgas emissions are necessary to verify site-specific risk assessment calculations

- Provide data needed for decision-making regarding management of stored wastes

- Assist in meeting milestones 


\section{Background of NWCF Offgas Characterization Studies}

- Calcination of nitric acid wastes produces offgas with high levels of $\mathrm{NO}_{x}$

- EPA's standard methods weren't developed or validated for offgas with high $\mathrm{NO}_{x}$ levels

- Significant sampling problems and erroneous measurements occur in presence of high $\mathrm{NO}_{x}$ concentrations

- Poor surrogate recoveries

- $\mathrm{NO}_{x}$ reactions with XAD-2 and Tenax sorbents in SVOC and VOC sample trains

- Corrosion and increased maintenance 


\section{Non-radioactive Bench \& Pilot= scale Tests (FY-98)}

- Investigate whether standard EPA methods could be used to sample calciner offgas for D/Fs, PAHs, PCBs, SVOCs, VOCs, and metals

- Determine if potential modifications to sample collection and analysis methods would improve sampling results

- Successful demonstration of test methods may lead to demonstration and emissions inventory on NWCF 


\section{Scope of Offgas Emissions Inventory}

- Monitoring and control of typical NWCF operating conditions

- Manual offgas sampling and analysis for $\mathrm{PM}, \mathrm{HCl}, \mathrm{Cl}_{2}$, selected metals including $\mathrm{Hg}$, VOCs, D/Fs, PAHs, PCBs, SVOCs, \& TO

- Offgas continuous emissions monitoring for gaseous species

- $\mathrm{O}_{2}, \mathrm{CO}_{2}, \mathrm{CO}, \mathrm{NO}, \mathrm{NO}_{2}, \mathrm{HCl}, \mathrm{THC}$

- Sample collection \& analysis of feed, scrub solution, calcine product, \& condensate 


\section{Challenges of Monitoring NWCF Offgas}

- The need to mitigate worker exposure to, and releases of, $\mathrm{NO}_{x}, \mathrm{HCl}, \mathrm{CO}$, and radioactivity was unprecedented

- Concentrations of $\mathrm{NO}_{2}, \mathrm{HCl}$, and $\mathrm{CO}$ were above IDLH limits

- Other unquantified IH hazards

- Serious radiological concerns

- Modifications of standard sampling and analysis procedures were required

- Non-standard sample access

- Need to mitigate $\mathrm{NO}_{x}$ interference

- Protect against offgas releases or worker exposure 


\section{Challenges of Monitoring NWCF Offgas (cont).}

- Project organization and implementation was very complex

- LMITCO project mgmt, engineers, technicians

- LMITCO RadCon engineers and RCTs

- LMITCO IS\&H

- LMITCO Safety engineers

- LMITCO Permitting

- LMITCO SMO, QA office, Shipping

- Testing subcontractor (SAIC)

- Analytical lab with necessary rad licenses and analytical capabilities (Quanterra Env. Services)

- Waste Generator Services 


\section{Challenges of Monitoring NWCF Offgas (cont.)}

- Work control documents were required:

- Test plan

- Quality assurance project plan

- NEPA/Environmental checklist

- Technical procedures for CEMs, port access

- MCP for sample shipping

- Emergency response procedures

- Training

- Rad Worker II

- Compressed gas

- Fire extinguisher

- Waste handling, etc. 


\section{Summary of Offgas Measurements}

- Gas velocity, temperature, swirl angle [2]

- SVOCs, PAHs, TCO and GRAV [0010/modified CARB 429]

- D/Fs and PCBs [0023A/CARB 428 (d)]

- Multiple metals including $\mathrm{Hg}$ [0060]

- $\mathrm{HCl}, \mathrm{Cl}_{2}, \mathrm{PM}$ [0050 modified for PM]

- VOCs [0030 and 0031]

- $\mathrm{O}_{2}, \mathrm{CO}_{2}, \mathrm{NO}, \mathrm{NO}_{2}, \mathrm{CO}, \mathrm{THC}, \mathrm{HCl}[3 \mathrm{~A}, 7 \mathrm{E}$, $10,25 \mathrm{~A}]$ 


\section{Representative Estimated NWCF Offaas Composition}
- $\mathrm{O}_{2}$
$17-18 \%$
- $\mathrm{CO}_{2}$
4-6\%
- $\mathrm{CO}$
1,000-5,000 ppm

- Primarily PIC of kerosene fuel due to low temp $\left(600^{\circ} \mathrm{C}\right)$ combustion

- NO

2,000-4,000 ppm

- $\mathrm{NO}_{2}$

$15,000-25,000 \mathrm{ppm}$

- 20 ppm IDLH, 1 ppm administrative limit

- THC 40-200 ppm

- Primarily PIC of kerosene fuel due to low temp $\left(500^{\circ} \mathrm{C}\right)$ combustion 


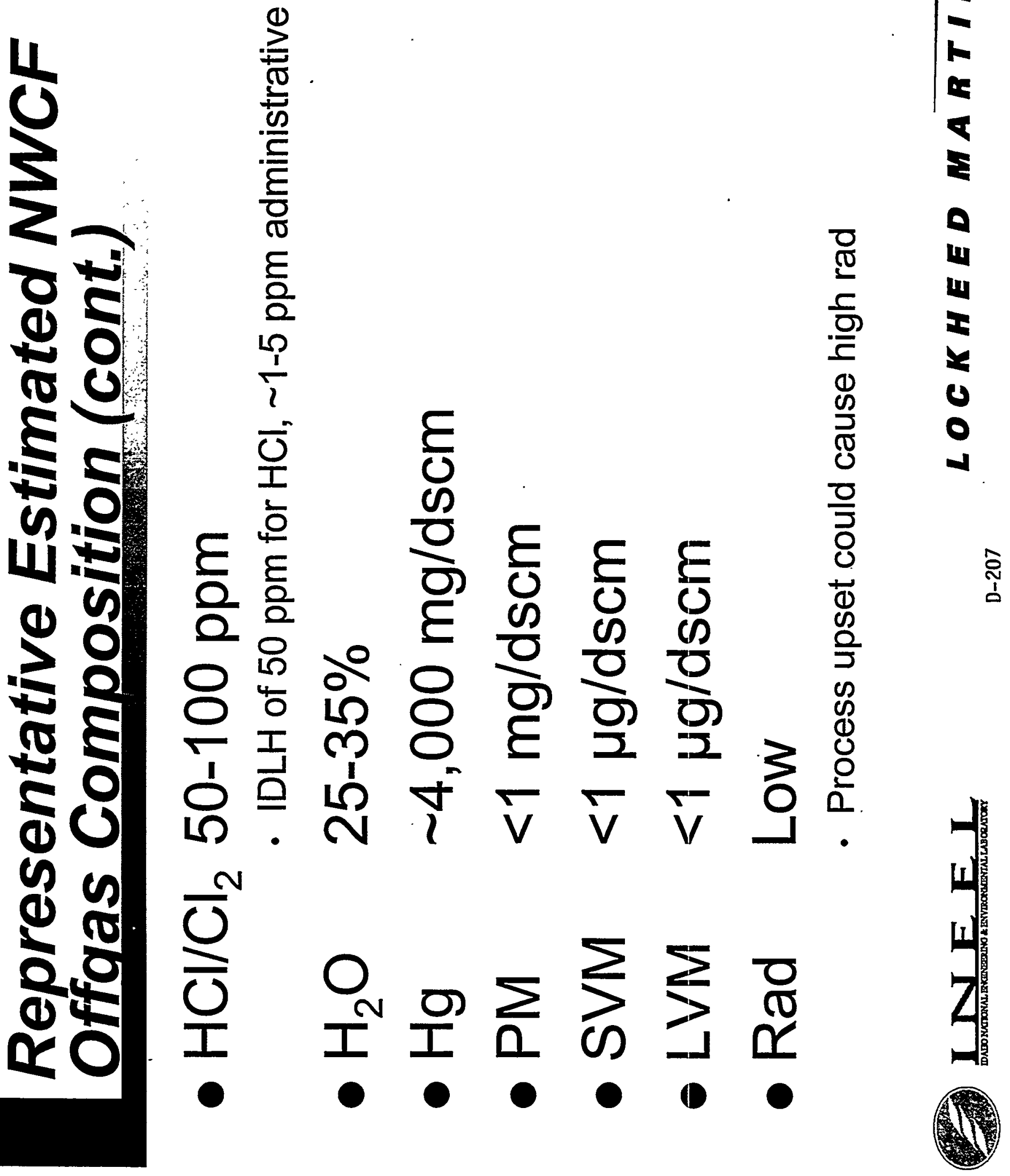




\section{Outcome of NWCF Offgas Emissions Inventory Project}

- Demonstrated technical feasibility of offgas measurements in high $\mathrm{NO}_{x}$ gas stream

- Established unprecedented procedures for safe sampling and analysis with acceptable data quality

- Supported screening level risk assessment

- Provide information about emissions during high temperature $\left(600^{\circ} \mathrm{C}\right)$ calciner operation 

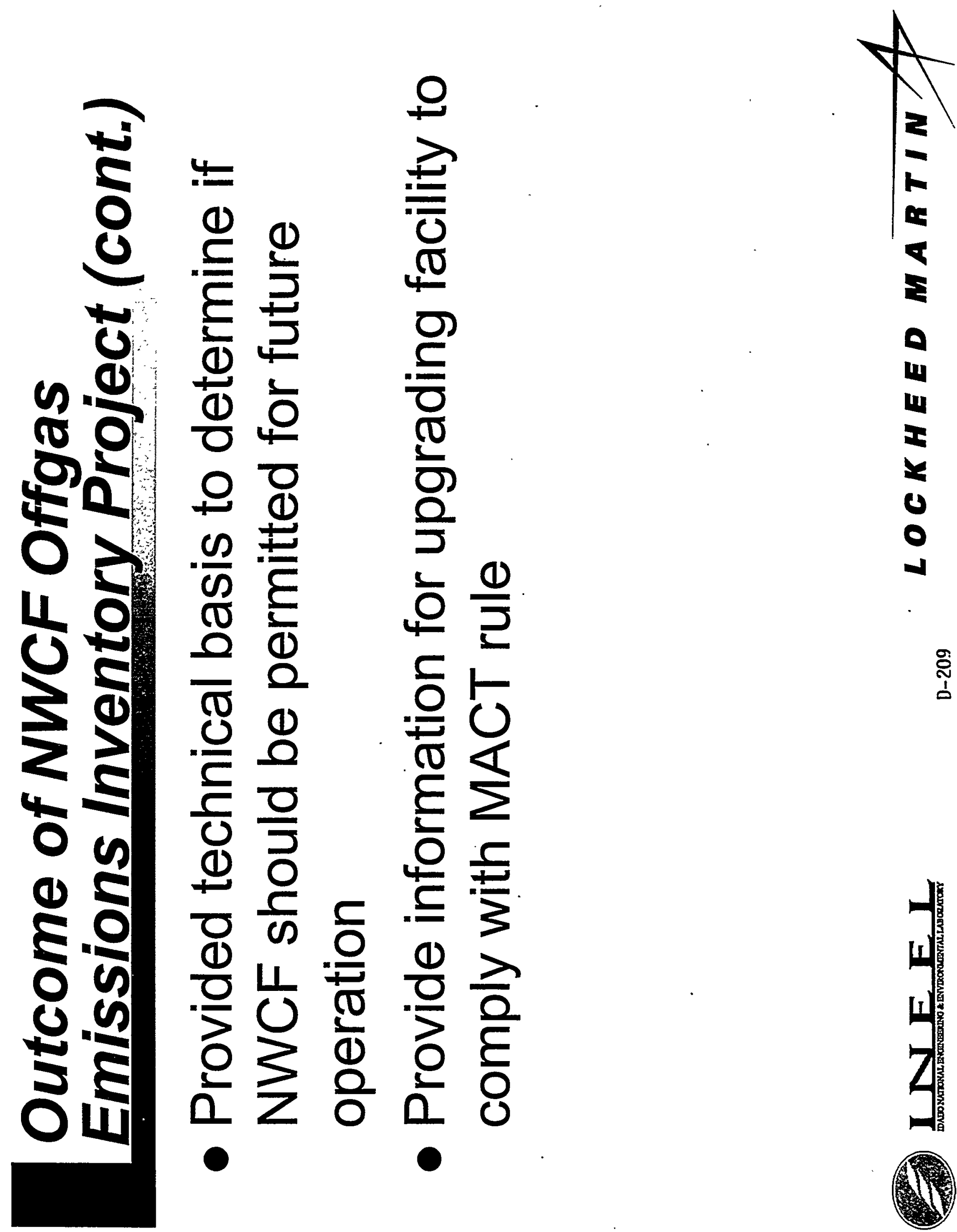


\section{Benefits of Emissions Inventory}

- Material balances used to improve current knowledge of fate of specific constituents

- Presence and fate of hazardous organic compounds in feed are better established

- Disposition of $\mathrm{Hg}$ in calcine solids, scrub, condensate, \& offgas will aid in developing a dynamic Hg mat'l balance model for NWCF

- Design Hg removal technology strategies

- Control $\mathrm{Hg}$ accumulation in tank farm wastes

- Continued NWCF operation under Consent Order 


\section{Requirements of Melter Offgas Treatment Systems}

- Mercury

- Rad components control

- Tc, Cs, Ru, I, others (volatilized or entrained)

- Particulate matter

- $\mathrm{HNO}_{3} / \mathrm{NO}_{\mathrm{x}}$

- $\mathrm{HCl} / \mathrm{Cl}_{2}$

- Organics

- D/Fs, PCBs, SVOC, VOC, PAH

- $\mathrm{HF} / \mathrm{F}_{2}$ 

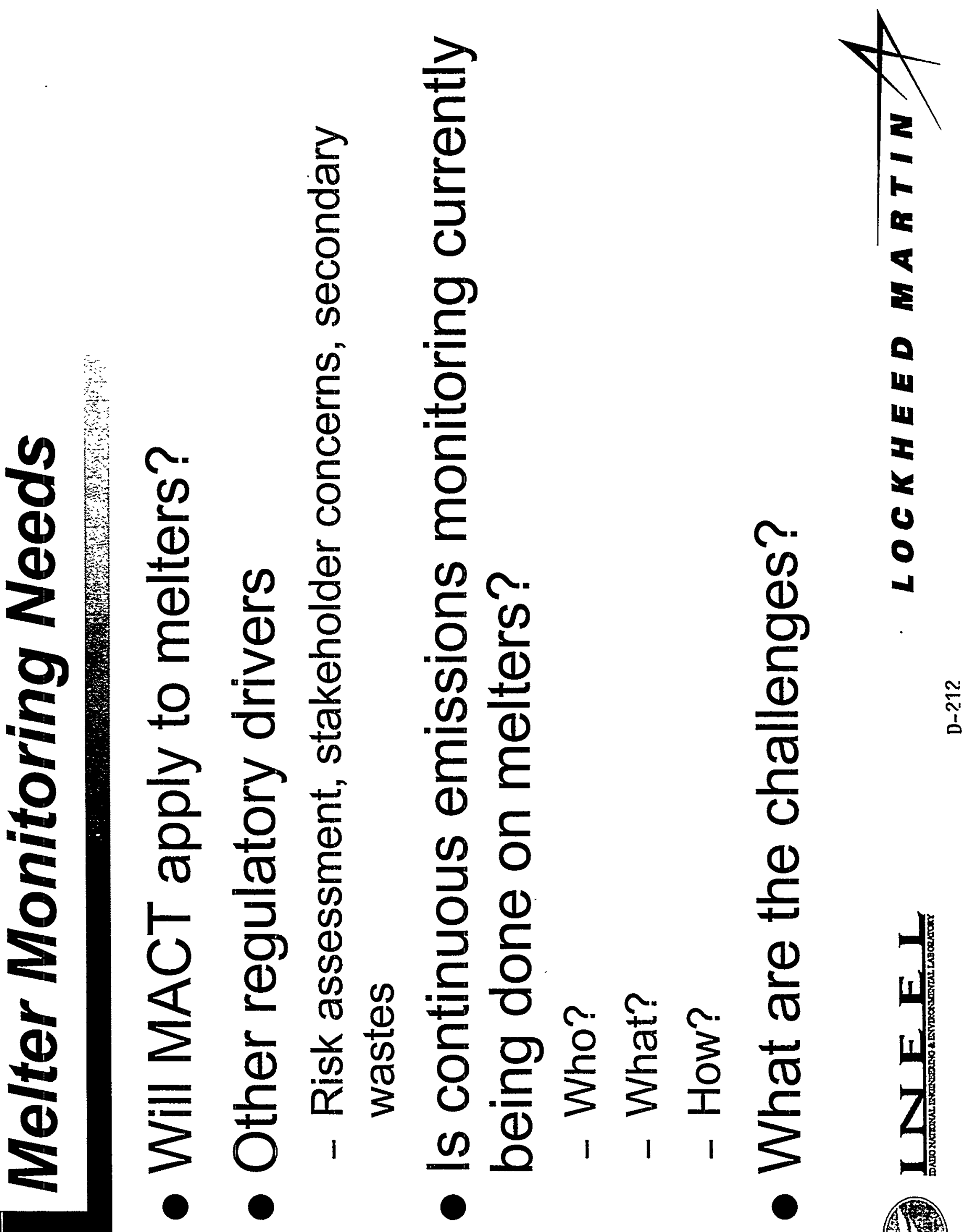


\section{Melter Monitoring Needs (cont.)}

- Which radioisotopes are most often seen in the offgas?

- Tc, Cs, I, Ru, others?

- To what extent do these isotopes volatilize?

- Entrainment?

- Form of mercury entering the offgas

- Elemental

- Salt

- $\mathrm{HF} / \mathrm{F}_{2}$ control

- Needs for further development 


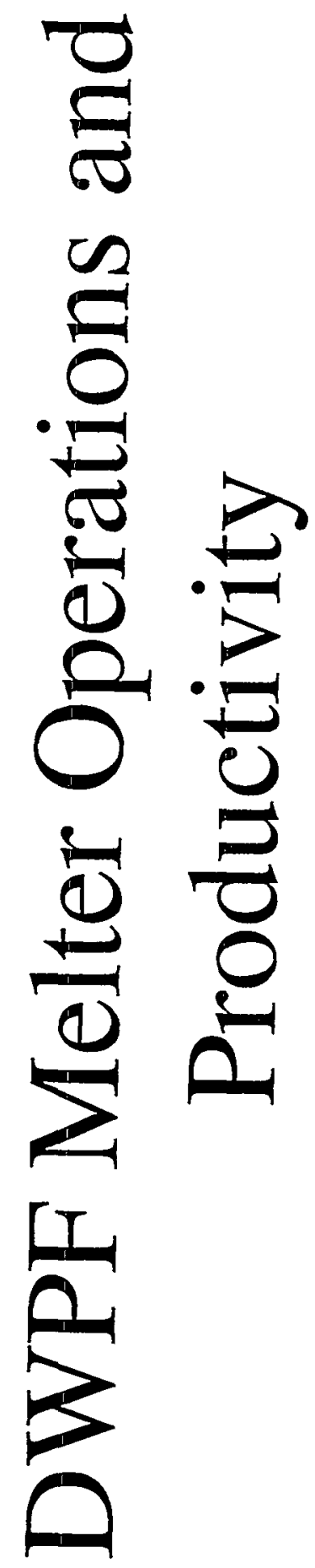




\section{HIGH LEVEL WASTE STORAGE}

51 Waste Tanks (originally; 2 closed 1997)

34 Million gallons in storage

Received as a liquid waste

Sludge Waste

$10 \%$ of the volume

$70 \%$ of the radioactivity

Salt Waste

$90 \%$ of the volume

$30 \%$ of the radioactivity 


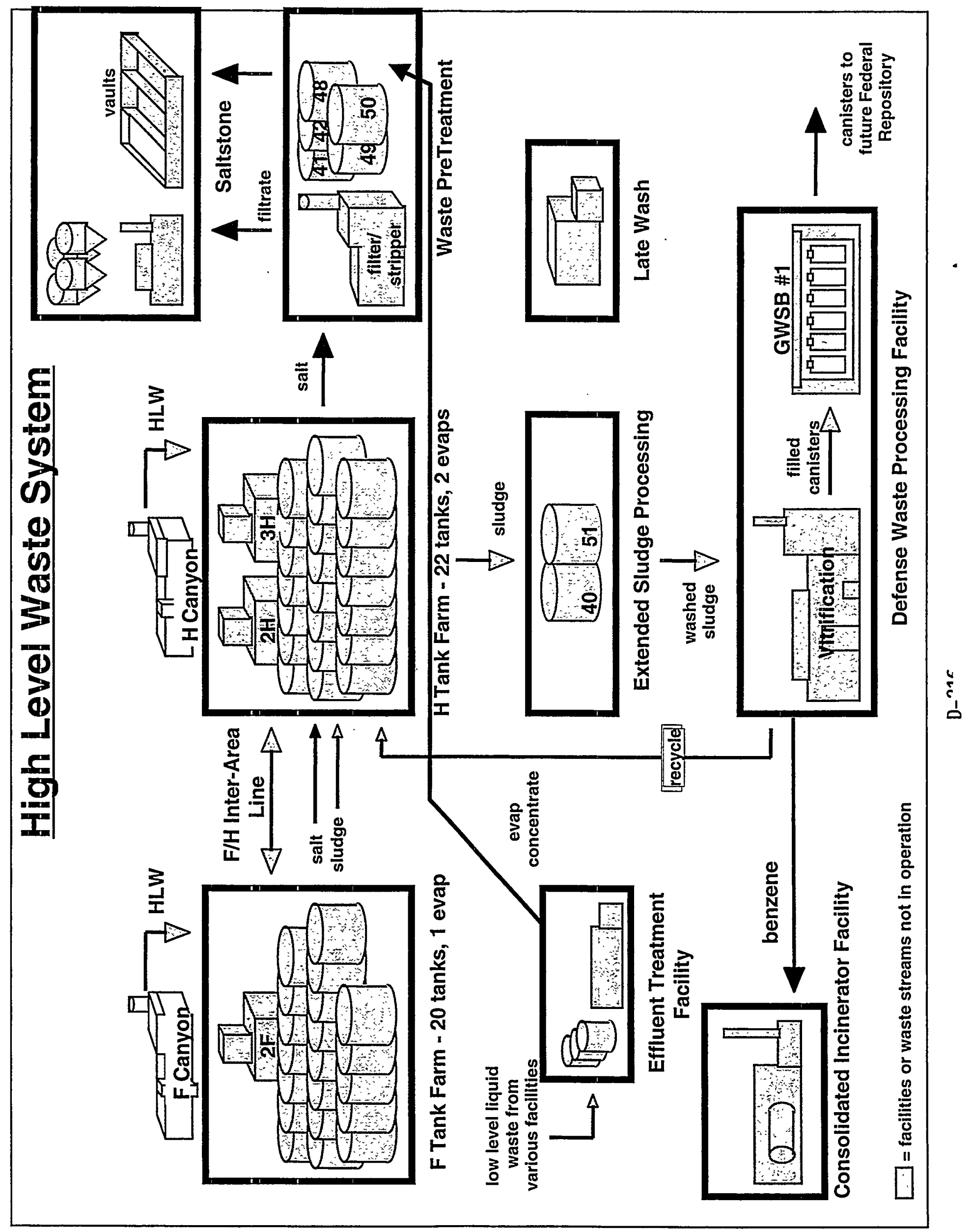




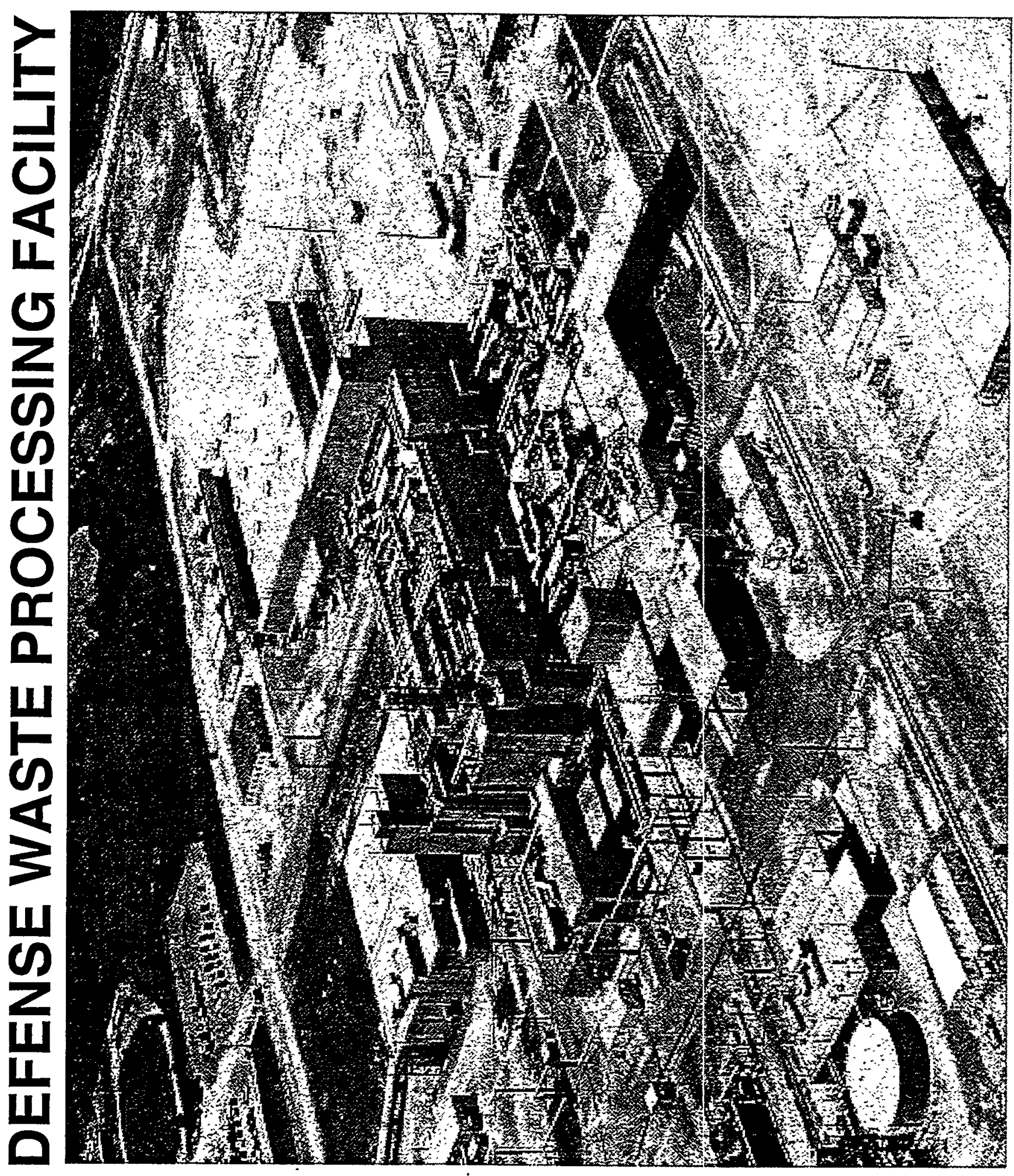

$\frac{1}{2}$ 


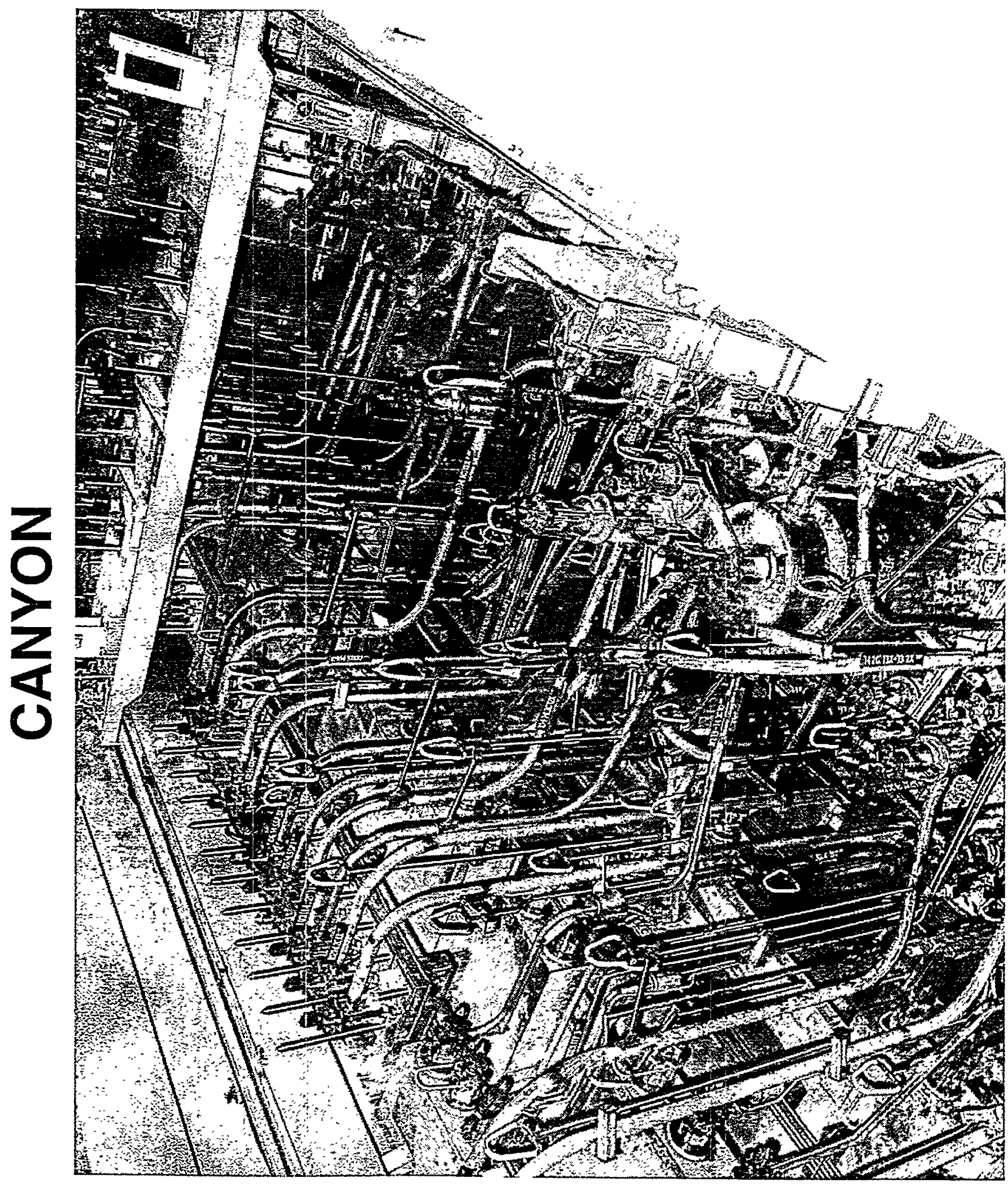



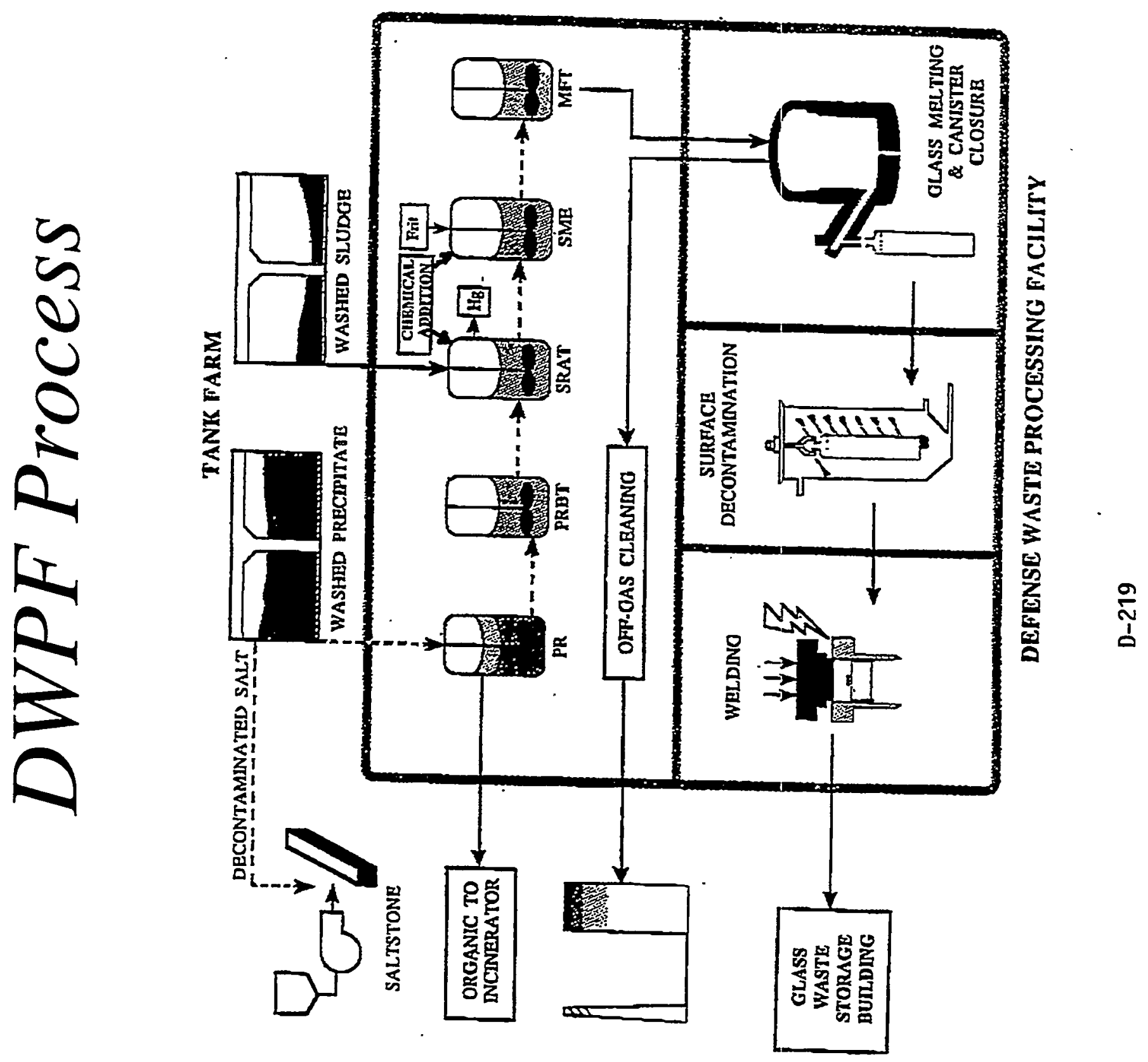

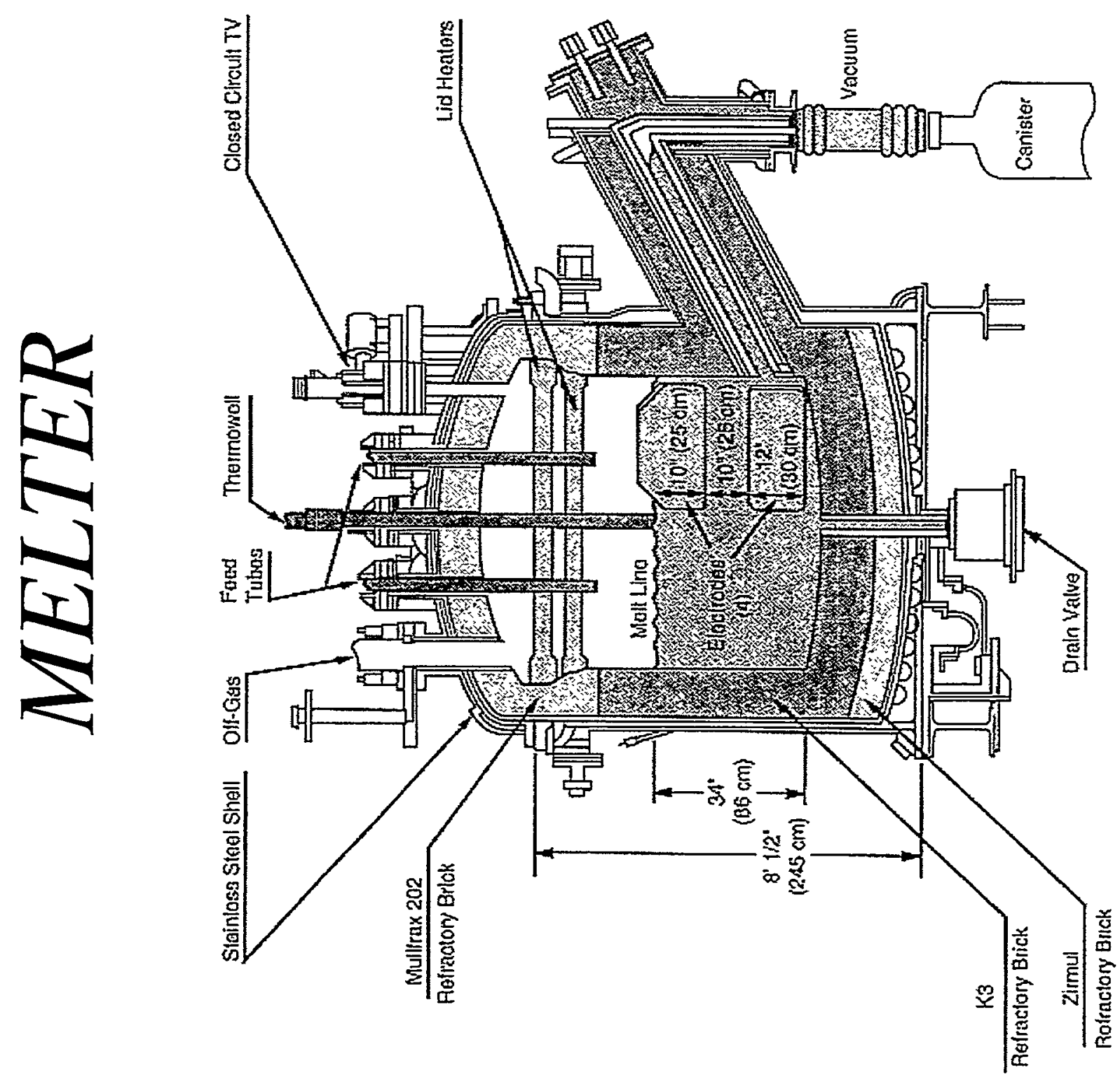


\section{DWPF Performance (Fiscal Years)}

- Actual Production

$\begin{array}{lcc} & \text { Goal } & \text { Actual } \\ \text { FY96* } & 60 & 64 \\ \text { FY97 } & 150 & 169 \\ \text { FY98 } & 200 & 250 \\ \text { FY99 } & 250 & 150 \\ & & \begin{array}{c}\text { (Thru 1 } \\ \text { st } \\ \text { months) }\end{array}\end{array}$

- Glass: 3800 pounds (1727 kg) per canister -Waste Processing: about 28 wt\% waste oxides

(*Commenced Radioactive Operations in 3/96) 


\section{DWPF Performance (Sludge Macrobatches)}

$\begin{array}{cccl}\text { Macrobatch } & \underline{\text { Dates }} & \text { Canisters } & \text { Characteristics } \\ 1 & 3 / 96-10 / 98 & 495 & \begin{array}{l}\text { Low Noble Metals } \\ \text { Low Mercury }\end{array} \\ 2 & 10 / 98 & \sim 600 & \begin{array}{l}\text { Low Noble Metals } \\ \text { Some Mercury }\end{array} \\ 3 & \text { (Actual Start) } & & \begin{array}{l}\text { Design Noble Metals } \\ \text { D/01 }\end{array} \\ & \text { (Projected Start) } & \sim 575 & \begin{array}{l}\text { Design Mercury } \\ \text { Design Radionuclides }\end{array}\end{array}$




\section{Melter Operation Timeline}

\begin{tabular}{|c|c|c|c|c|c|}
\hline \multirow[b]{2}{*}{ Dates } & \multirow[b]{2}{*}{ Event } & \multicolumn{2}{|c|}{ Non-Radioactive Glass } & \multicolumn{2}{|c|}{ Radioactive Glass } \\
\hline & & $\underline{\text { Cans }}$ & Pounds & $\underline{\text { Cans }}$ & $\underline{\text { Pounds }}$ \\
\hline $5 / 11 / 94$ & Initial Joule Heating & & & & \\
\hline $5 / 27 / 94$ & First Pour & & & & \\
\hline $6 / 94-2 / 96$ & $\begin{array}{l}\text { Cold runs, Waste } \\
\text { Quals, Proficiency } \\
\text { Runs }\end{array}$ & 80 & $\begin{array}{l}304,000 \\
\text { (138 metric tons) }\end{array}$ & & \\
\hline $3 / 96-5 / 97$ & $\begin{array}{l}\text { Macrobatch } 1 \text { Sludge } \\
\text { (w/o Inserts) }\end{array}$ & & & 131 & 529,000 \\
\hline $5 / 97-10 / 98$ & $\begin{array}{l}\text { Macrobatch } 1 \text { Sludge } \\
\text { (w/Inserts) }\end{array}$ & & & 364 & $1,434,000$ \\
\hline $10 / 98-4 / 99$ & $\begin{array}{l}\text { Macrobatch } 2 \text { Sludge } \\
\text { (w/Inserts) }\end{array}$ & & & 150 & 525,000 \\
\hline & D & & Total: & 645 & $\begin{array}{r}\mathbf{2 , 4 8 8 , 0 0 0} \\
(1,131 \text { metric } \\
\text { tons })\end{array}$ \\
\hline
\end{tabular}




\section{Melter Design Basis}

\section{Design Life}

- 2 year operating life

- $228 \mathrm{lb} / \mathrm{hr}(100 \mathrm{~kg} / \mathrm{hr})$ glass pour rate $\left(8 \mathrm{lbs} / \mathrm{hr} \mathrm{ft}^{2}-38 \mathrm{~kg} / \mathrm{hr} \mathrm{m}^{2}\right)$

- 2.0 million pounds (900 metric tons) glass (100\% facility attainment for 2 years)

\section{Melter \# 1}

- 5 years at operating temperature

- Glass pour rates at $180-240 \mathrm{lb} / \mathrm{hr}(80-110 \mathrm{~kg} / \mathrm{hr})$

- Nominal production of $\sim 1$ canister/day

- 2.8 million pounds of glass poured thru 4/30/99 


\section{DWPF Canister Production Using Melter Pour Spout Inserts}

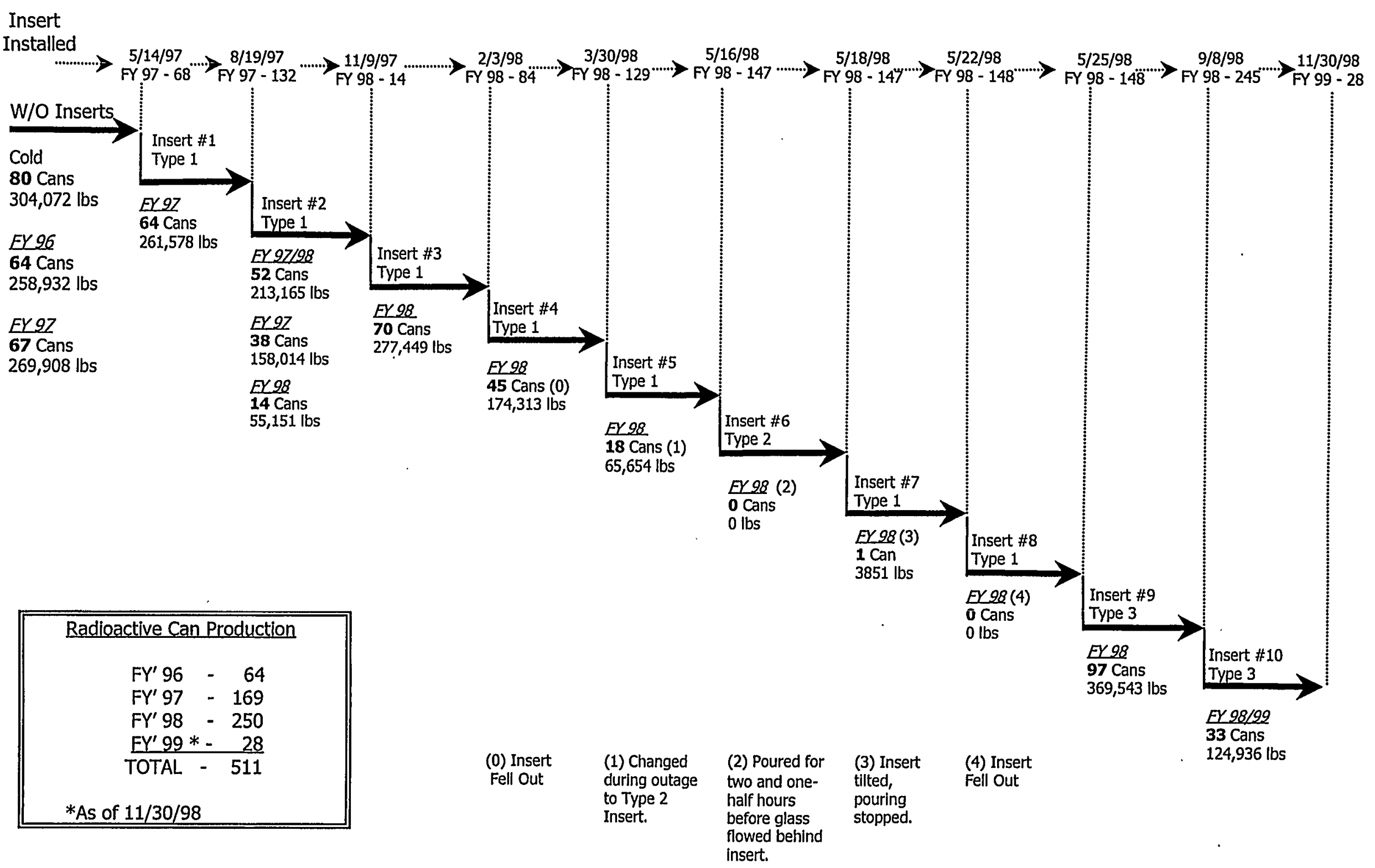




\section{DWPF Glass Processing Constraints}

- Durability

- Product Consistency Test (PCT) results 2 standard deviations less than Environmental Assessment (EA) glass

- Liquidus

$-<1050^{\circ} \mathrm{C}$

- Glass Viscosity

- 20 - 100 poise

- Solubility Limits

- $\mathrm{TiO}_{2}<1 \mathrm{wt} \%$

$-\mathrm{Na}_{2} \mathrm{SO}_{4}<0.59 \mathrm{wt} \%$

$-\mathrm{P}_{2} \mathrm{O}_{5}<2.25 \mathrm{wt} \%$

$-\mathrm{Cr}_{2} \mathrm{O}_{3}<0.3 \mathrm{wt} \%$

$-\mathrm{N}_{\mathrm{a}} \mathrm{Cl}<1.0 \mathrm{wt} \%$

$-\mathrm{N}_{\mathrm{a}} \mathrm{F}<1.0 \mathrm{wt} \%$

$-\mathrm{Cu}<0.5 \mathrm{wt} \%$ 


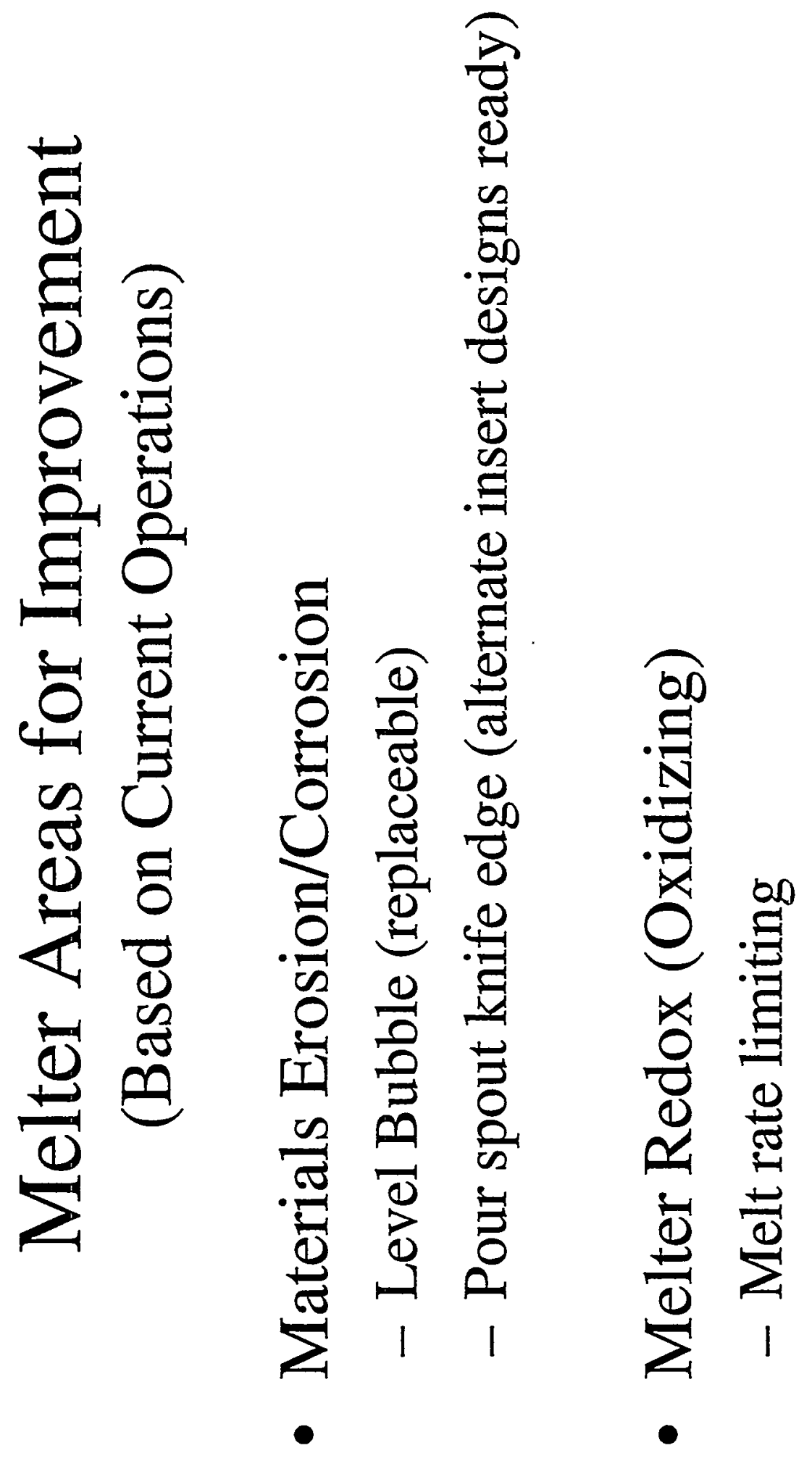



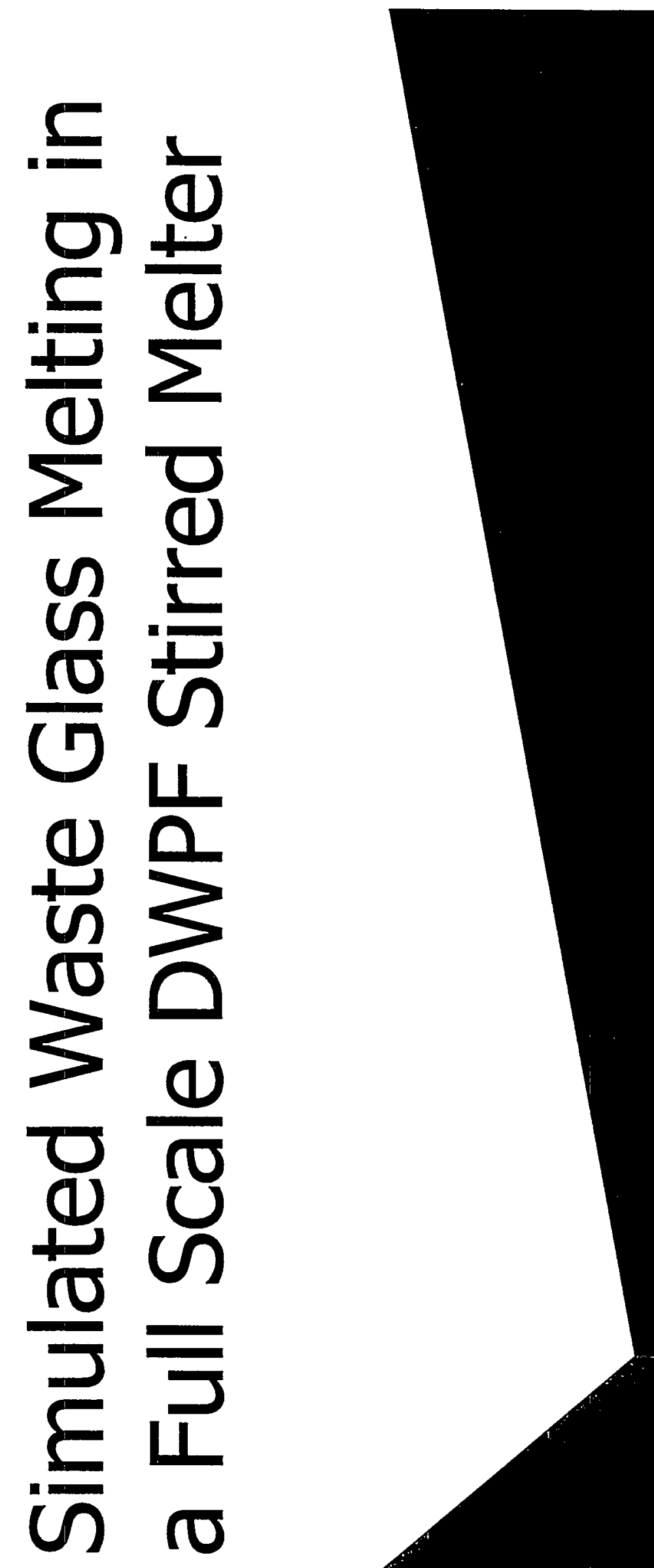

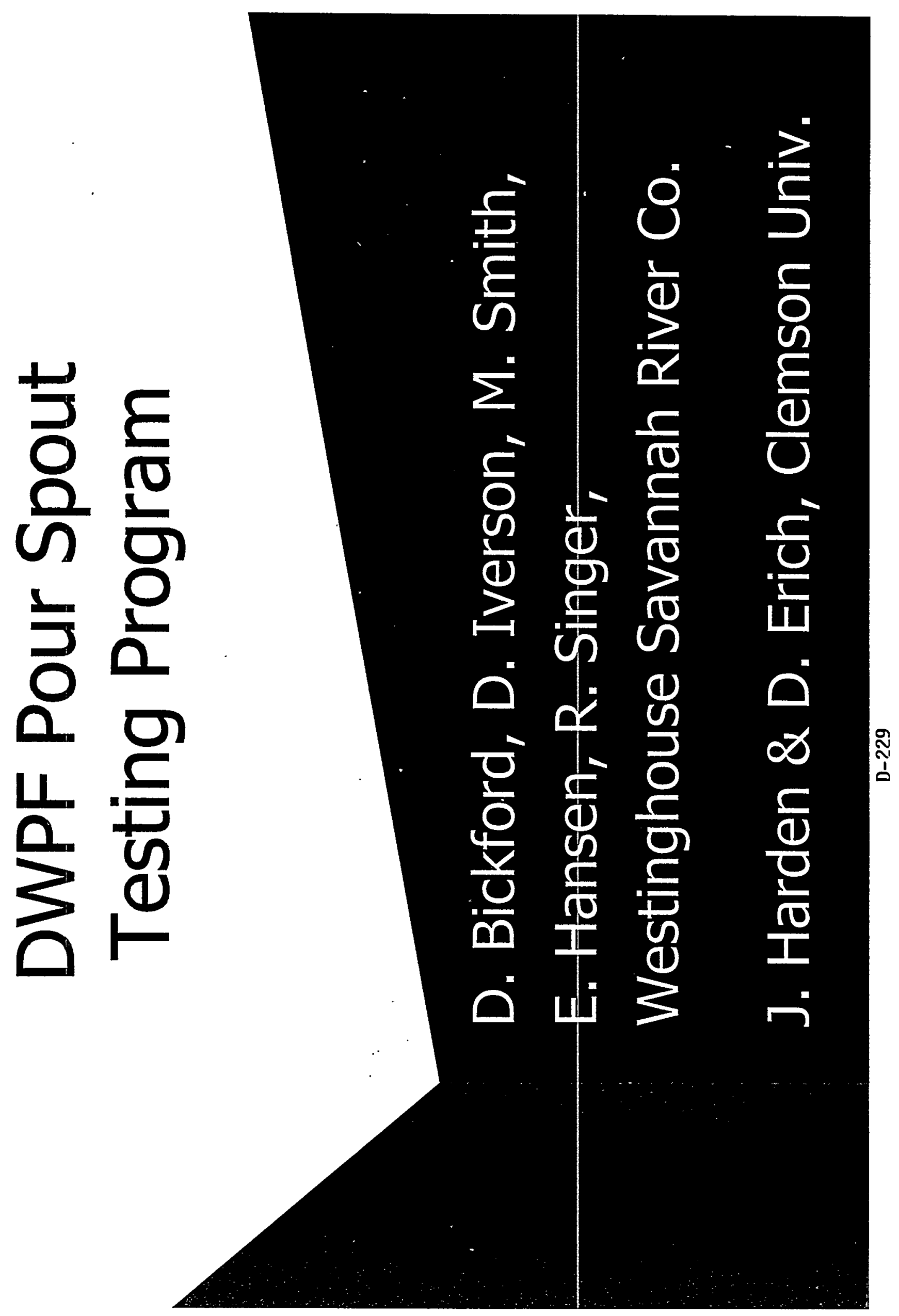


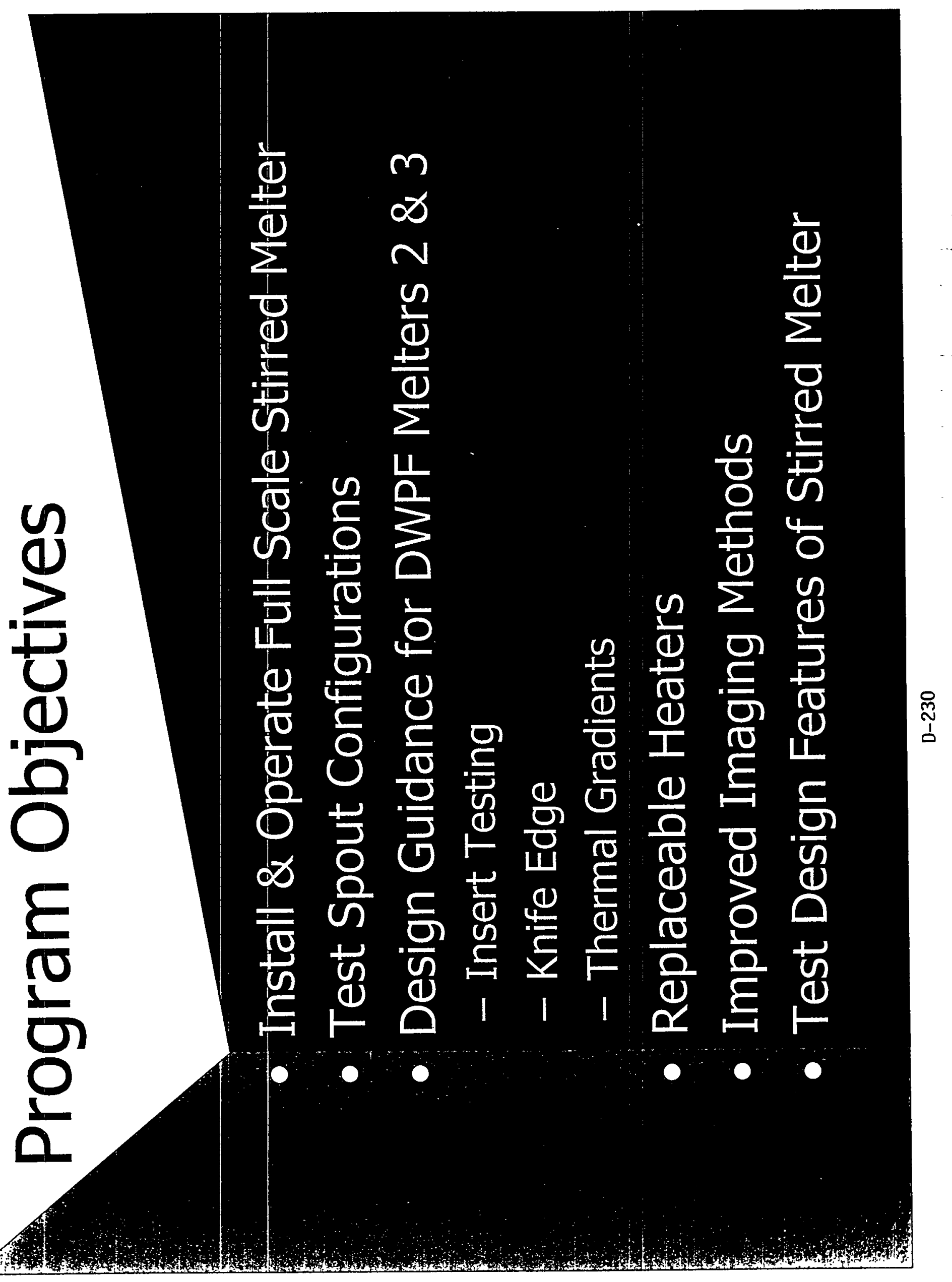




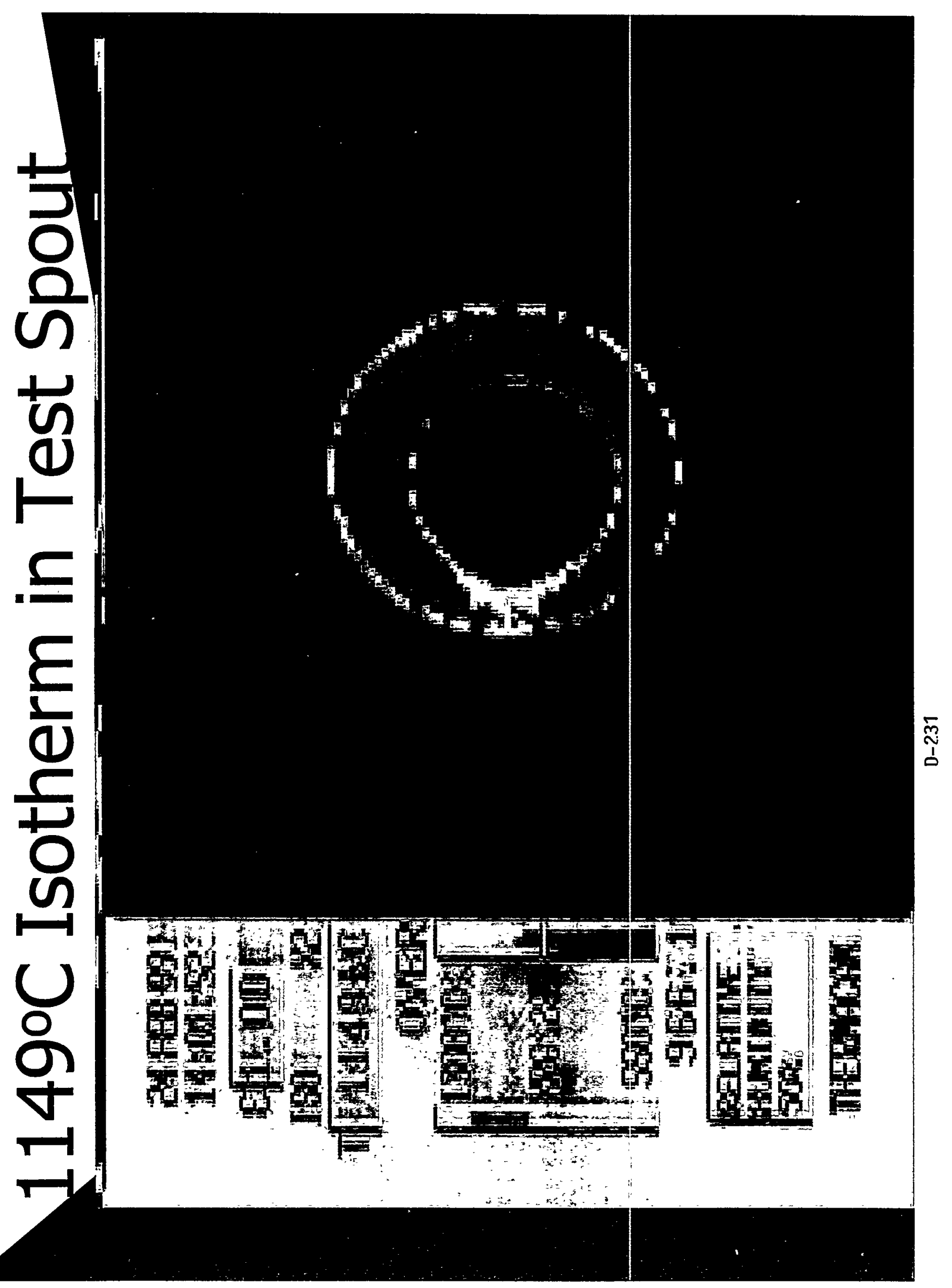




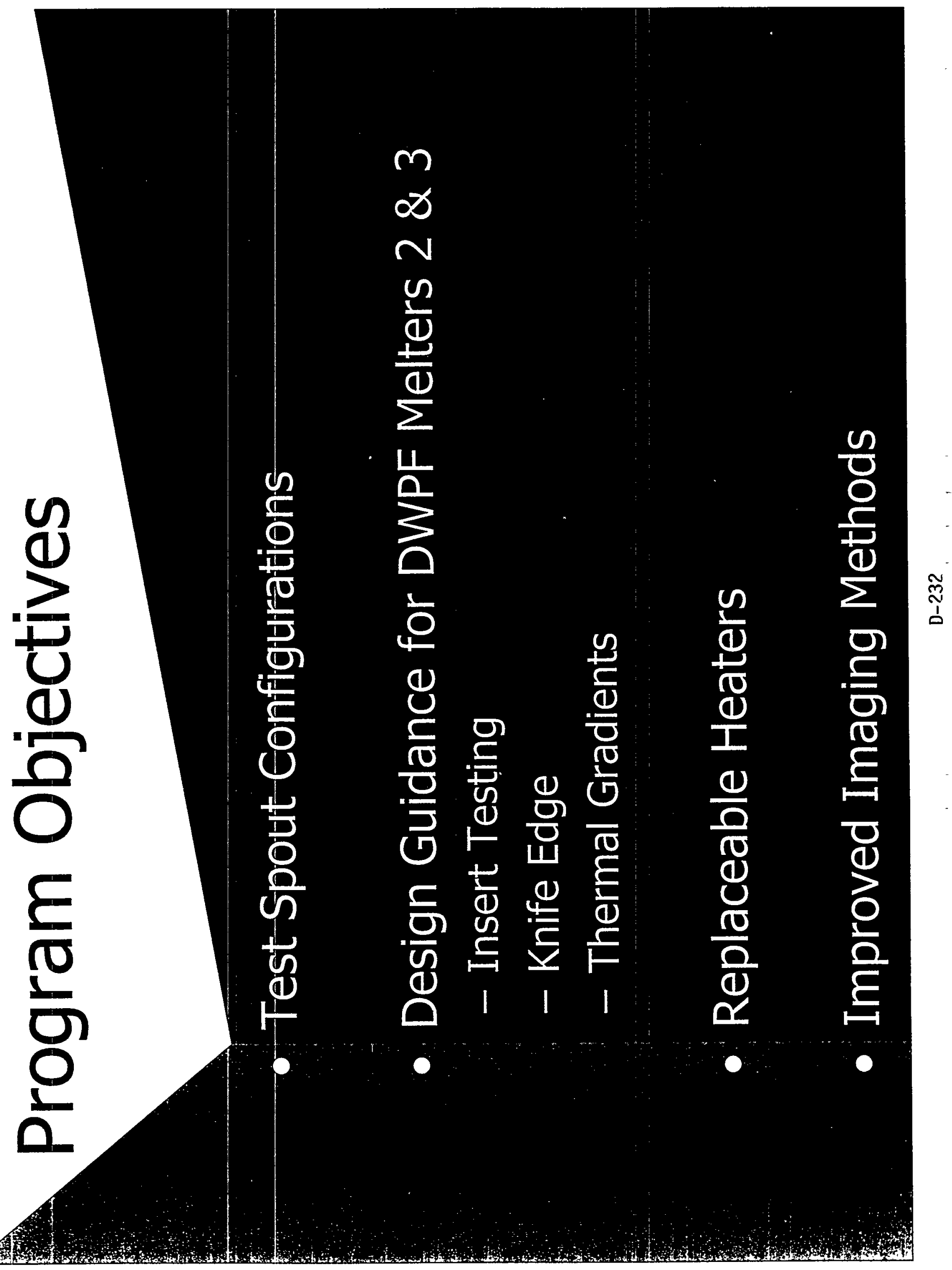




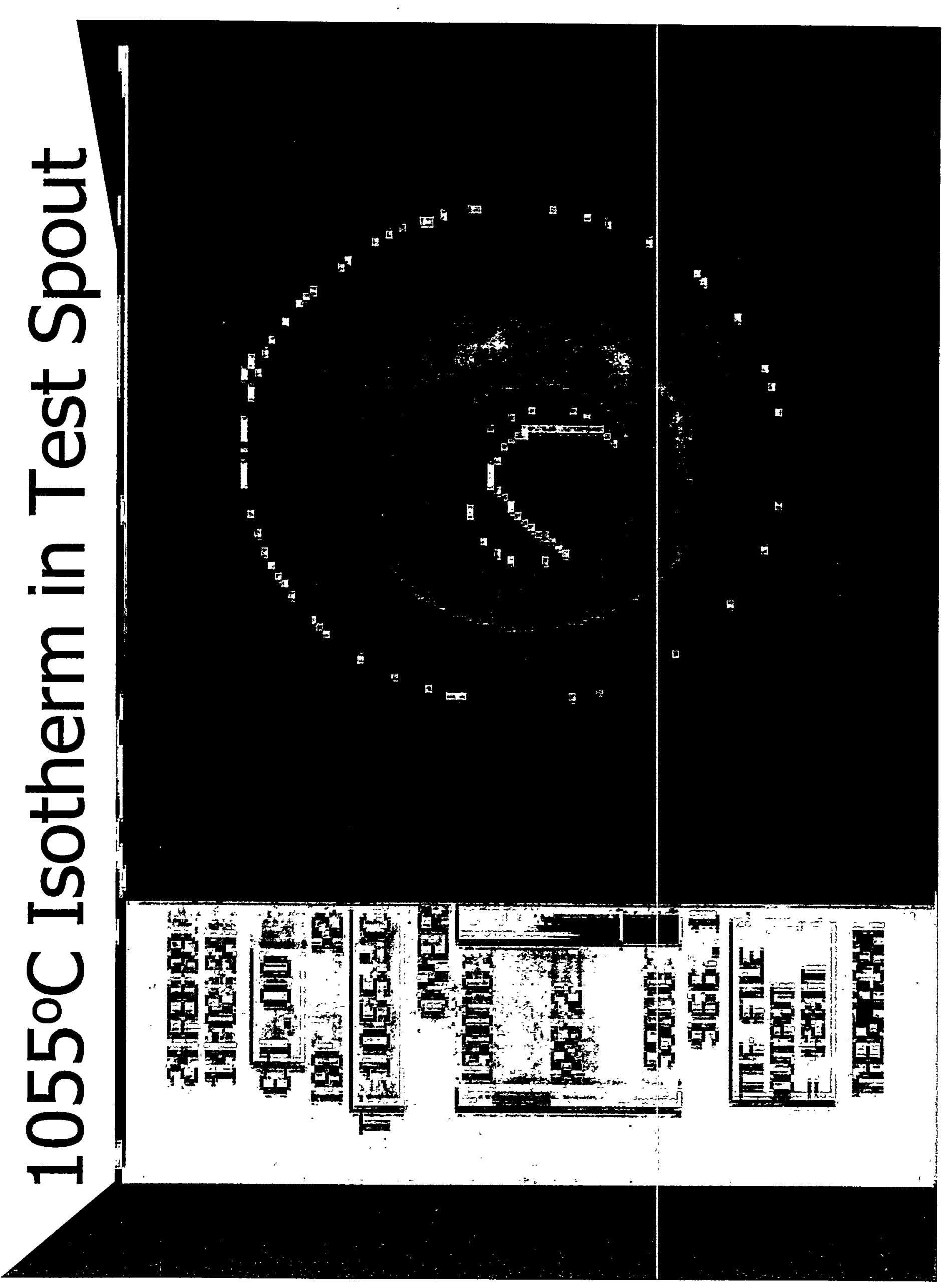




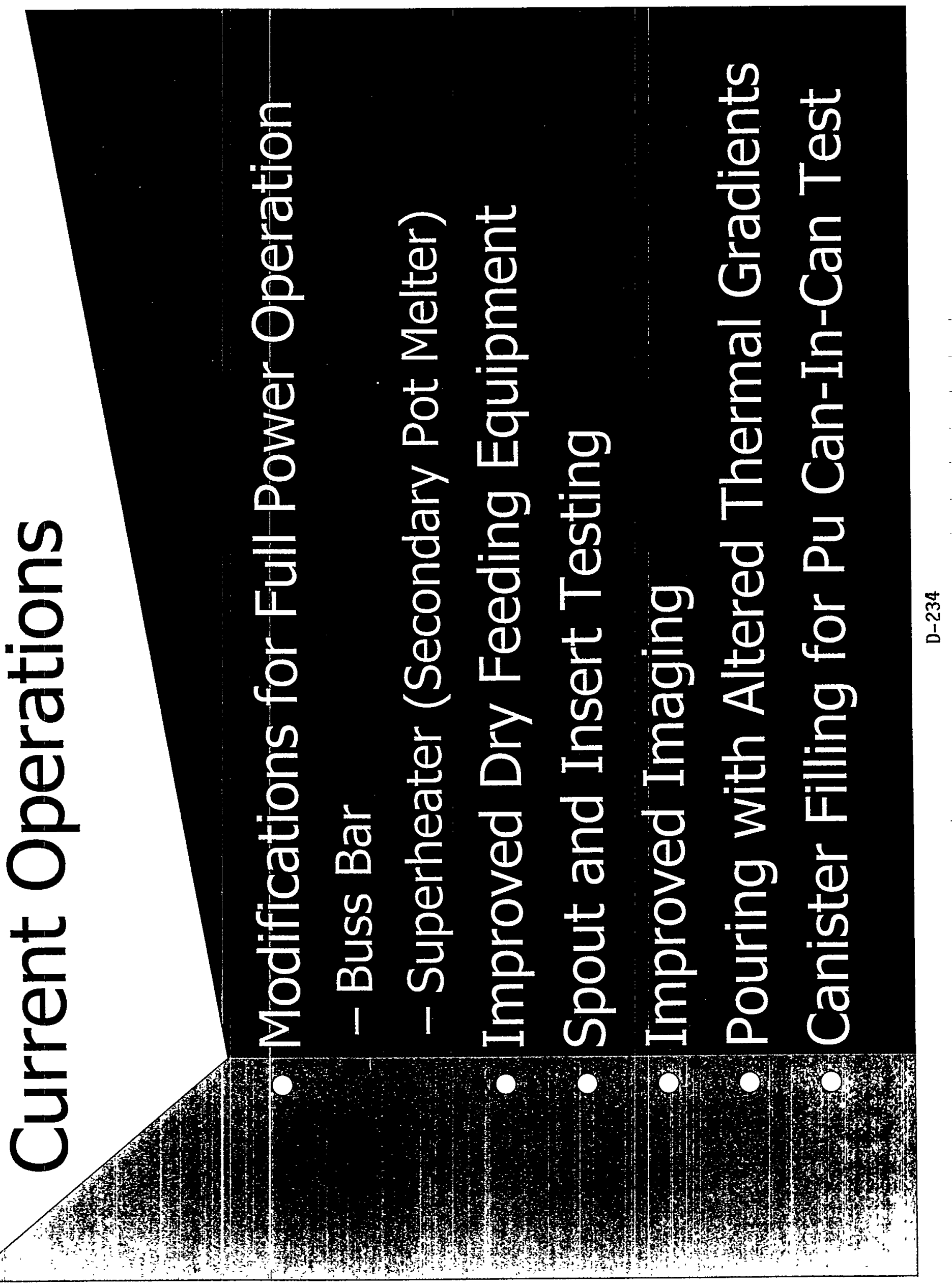




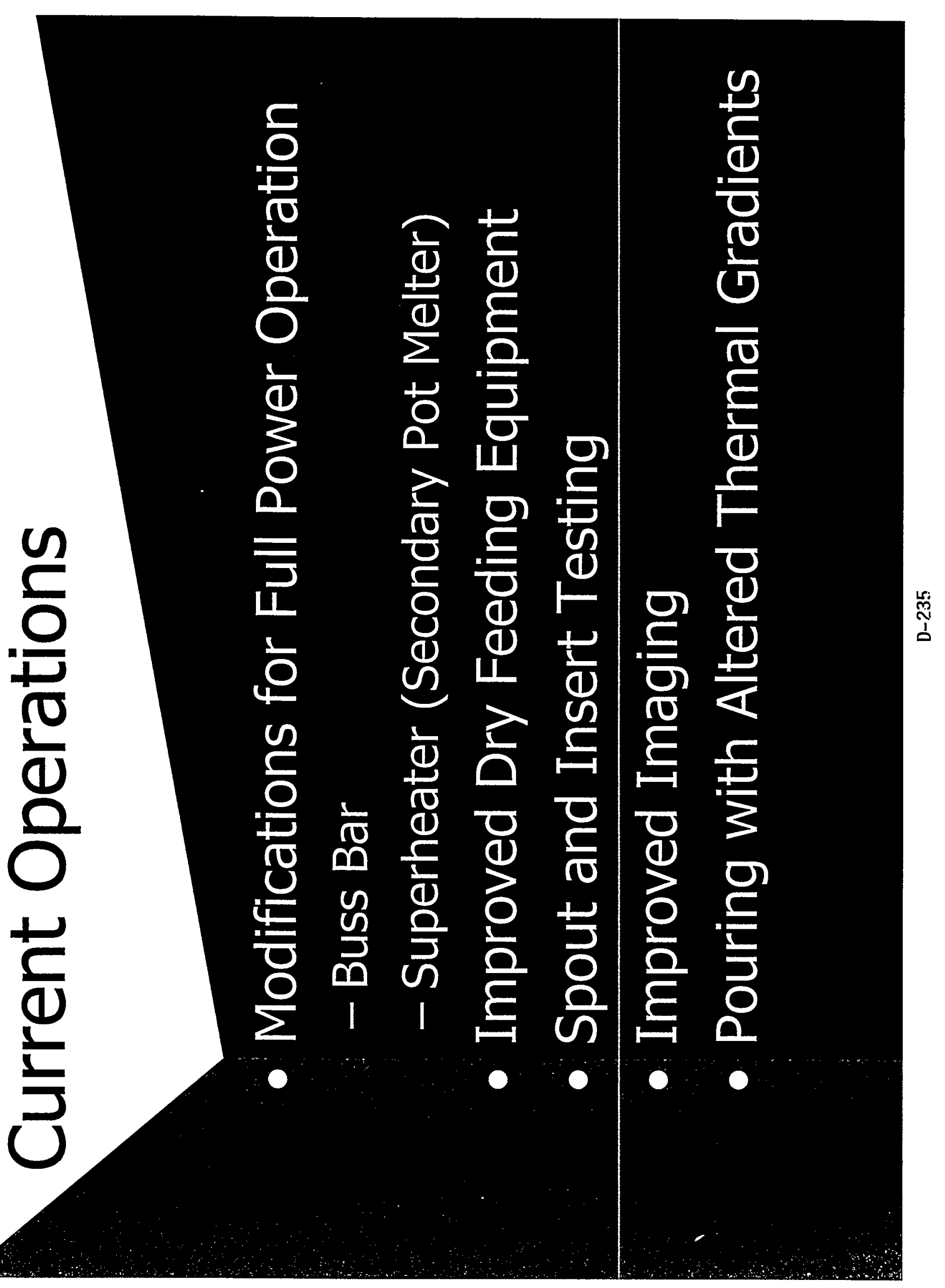




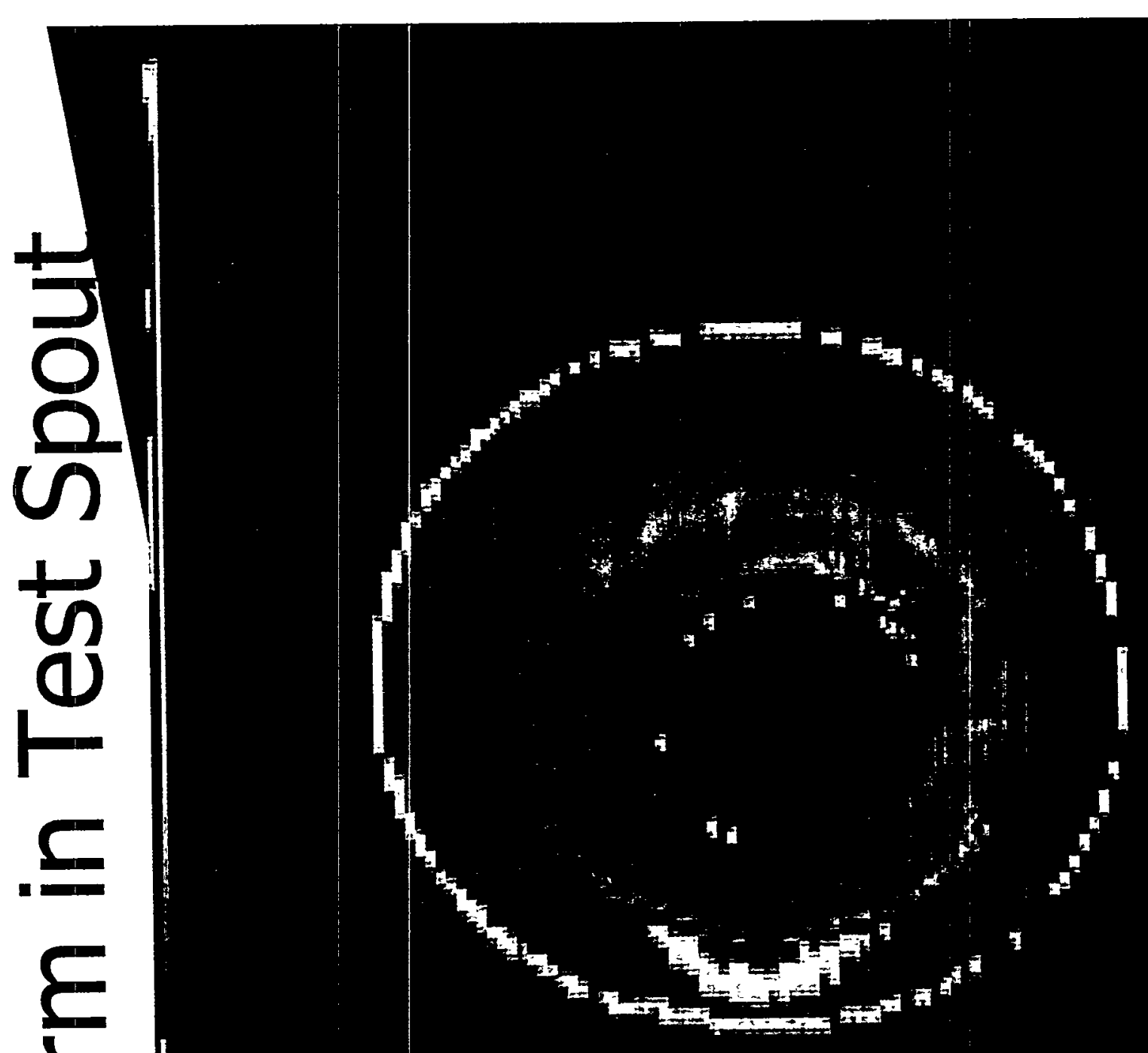

$\underset{\mathscr{N}}{\stackrel{\sim}{d}}$ ates aj
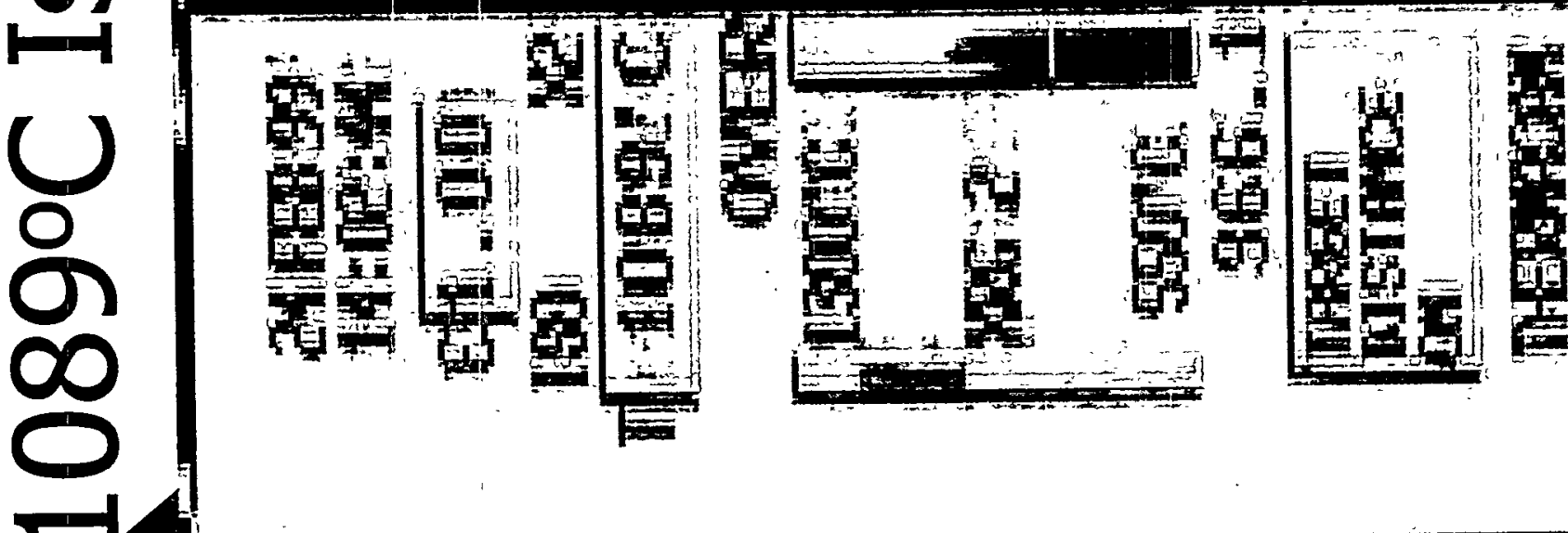


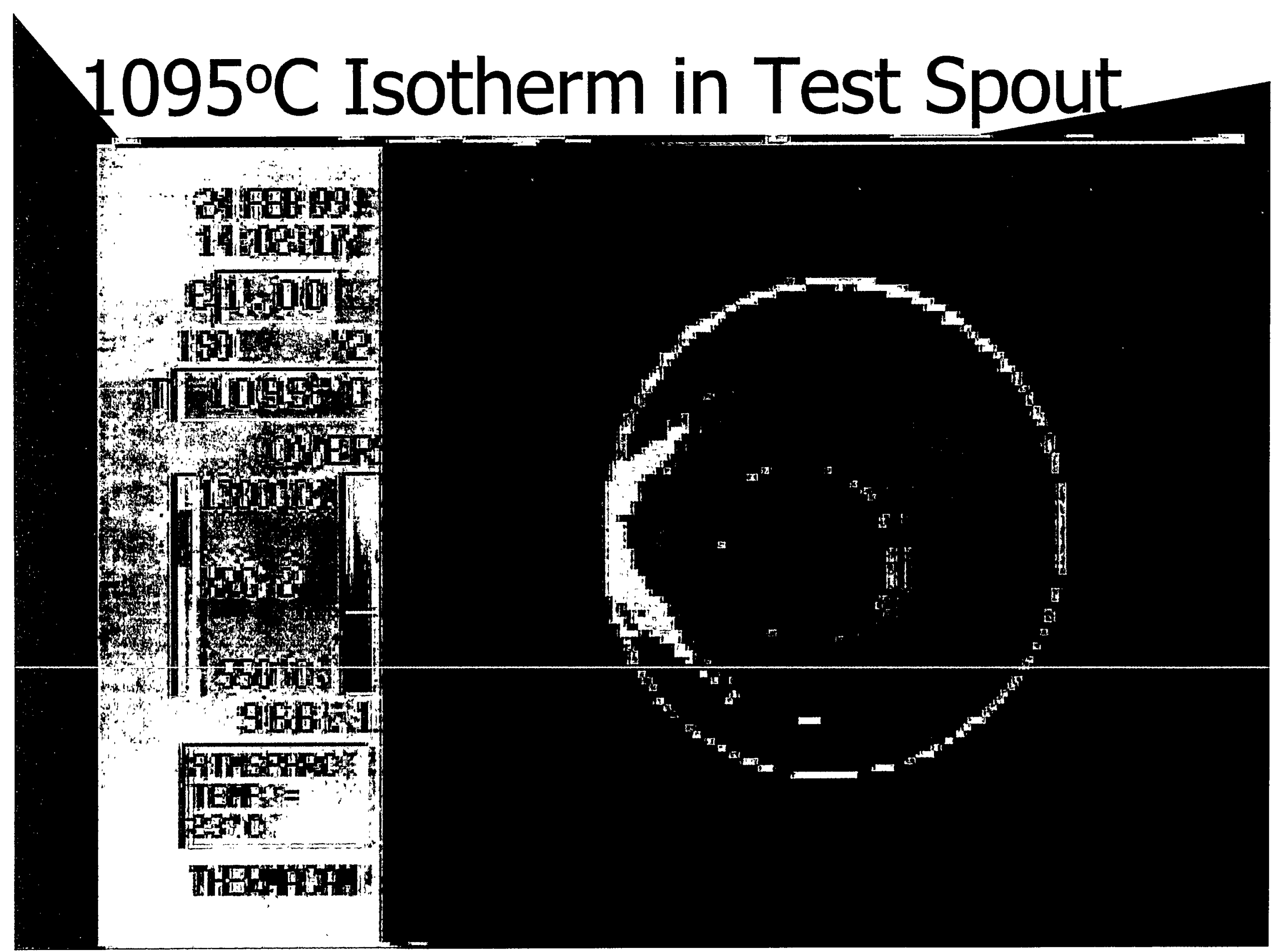




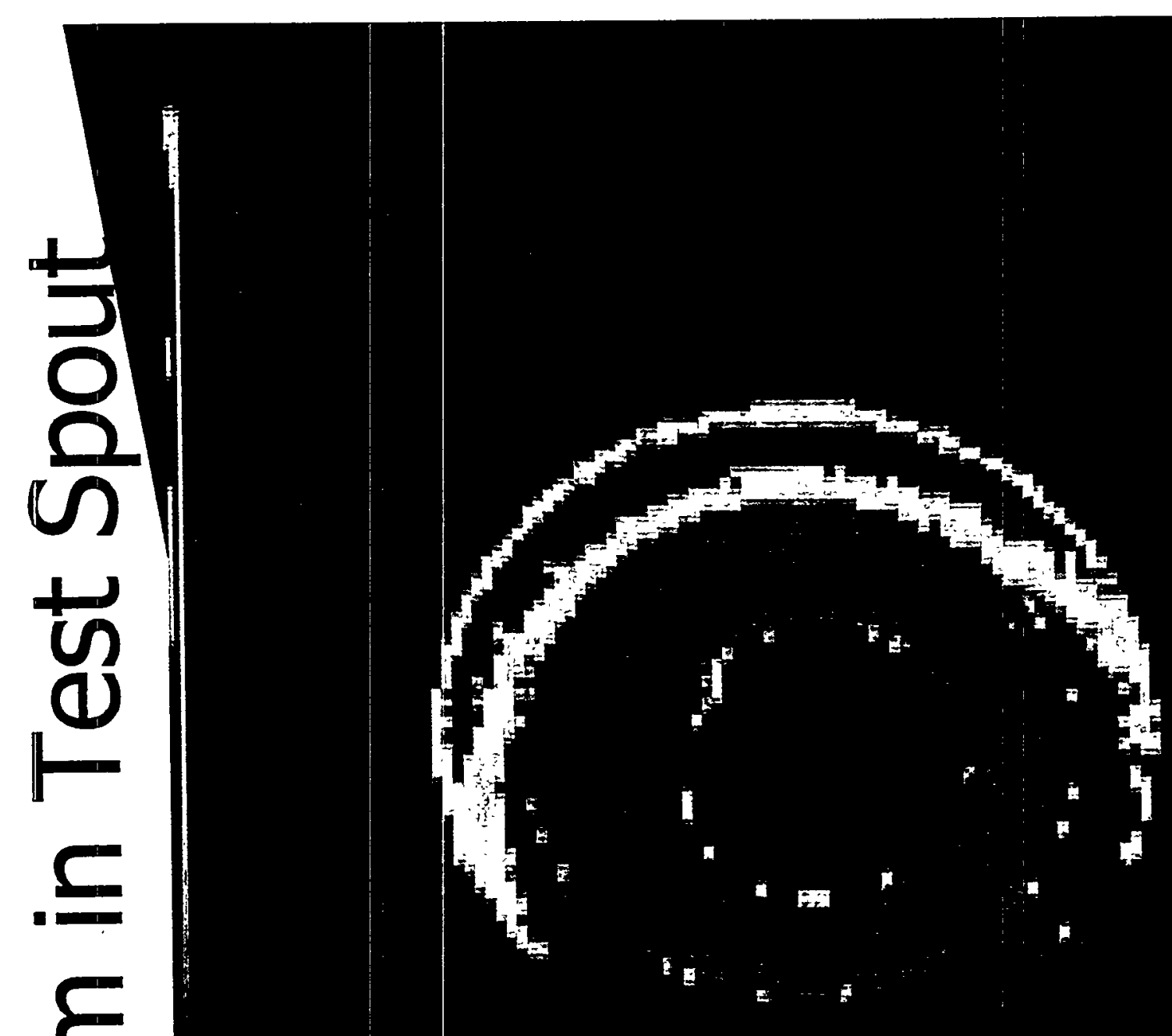

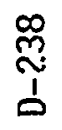




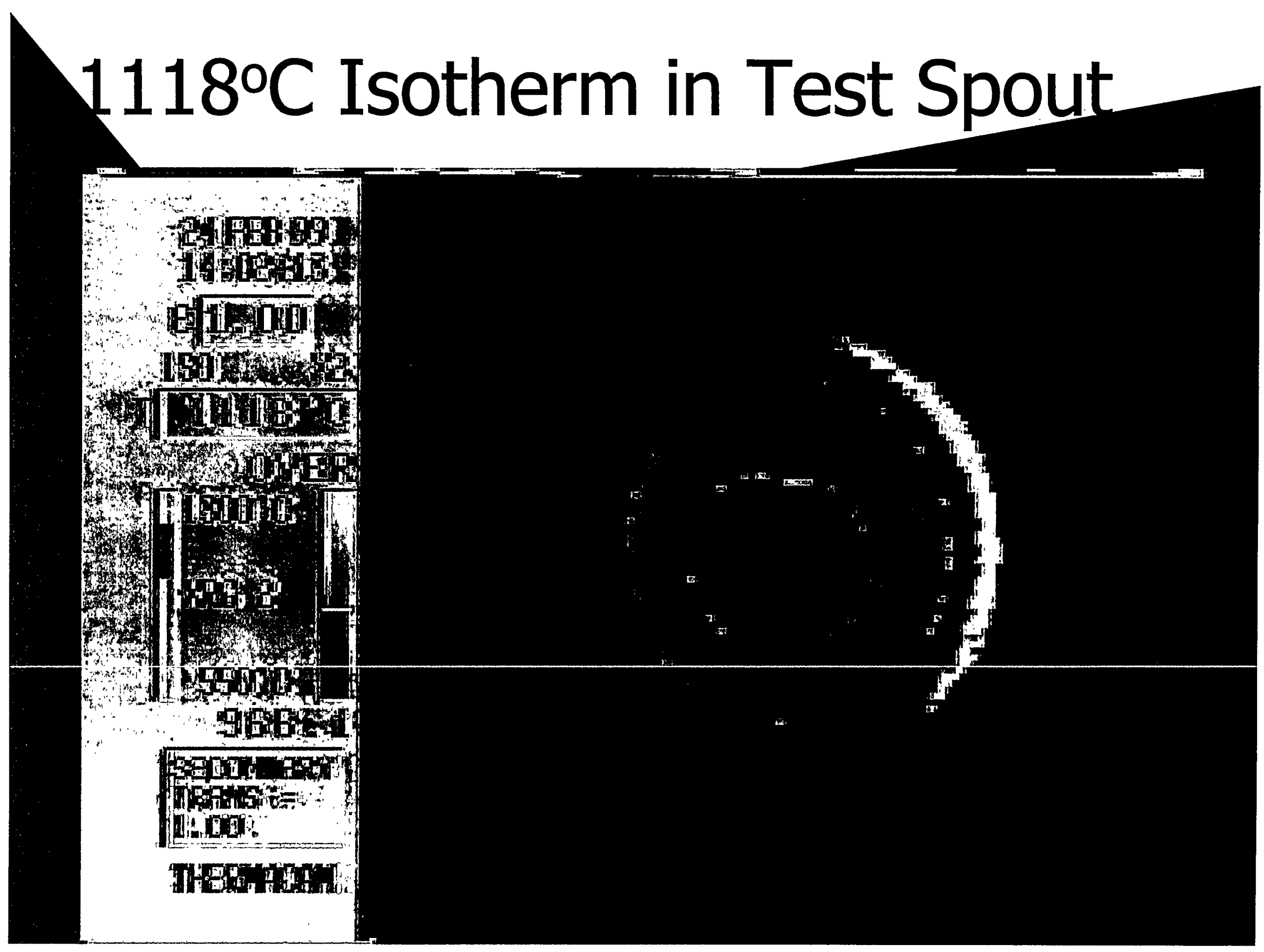




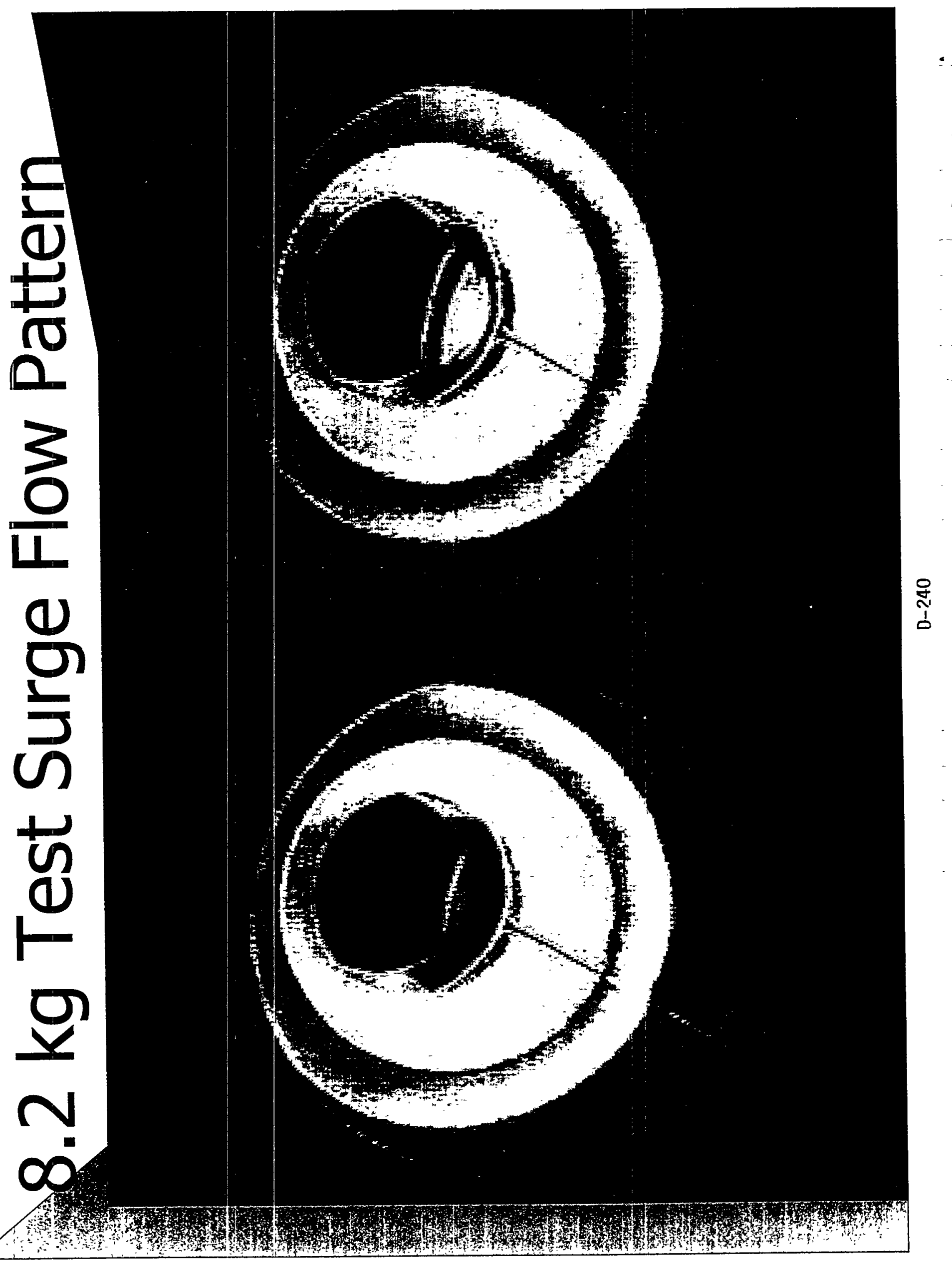




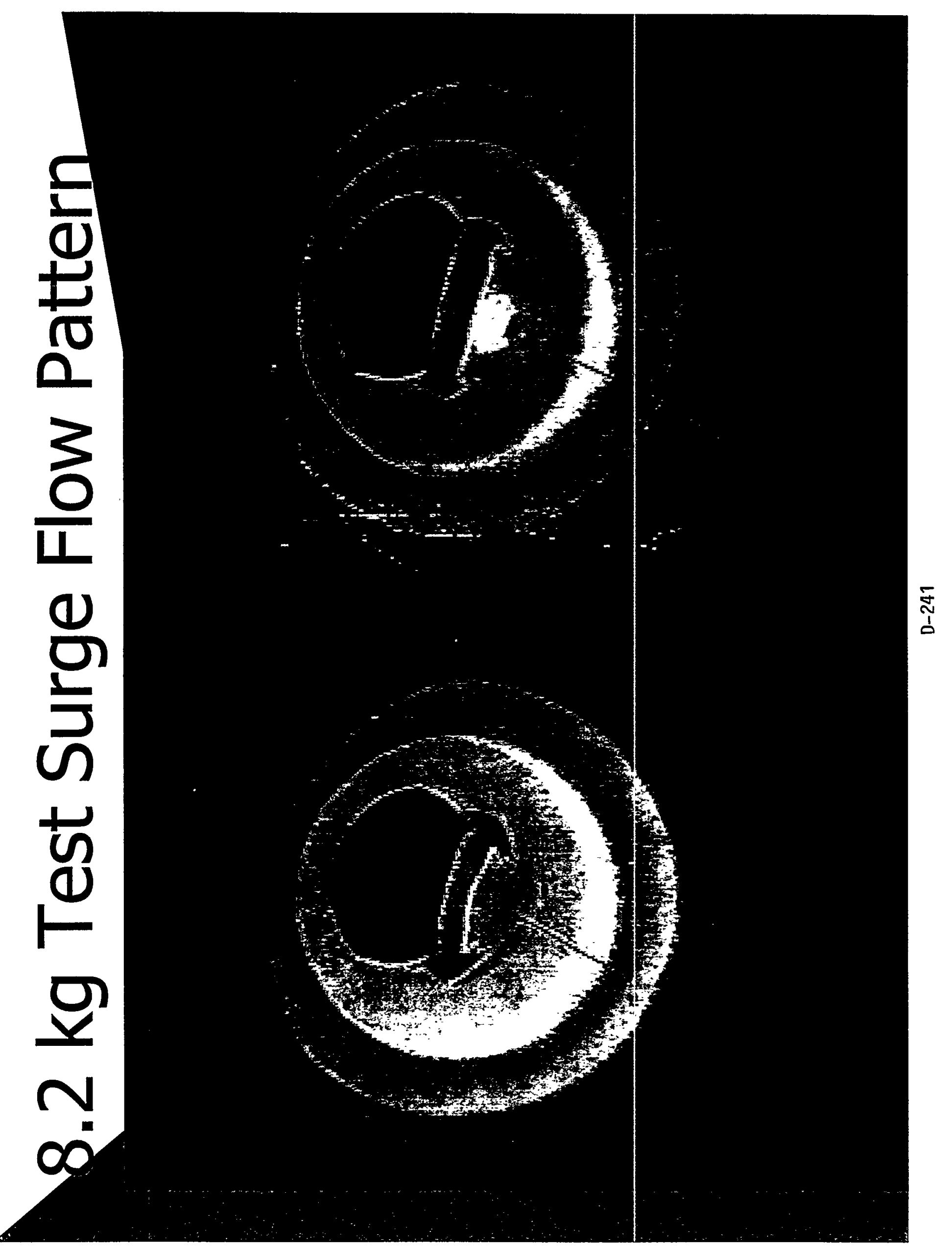




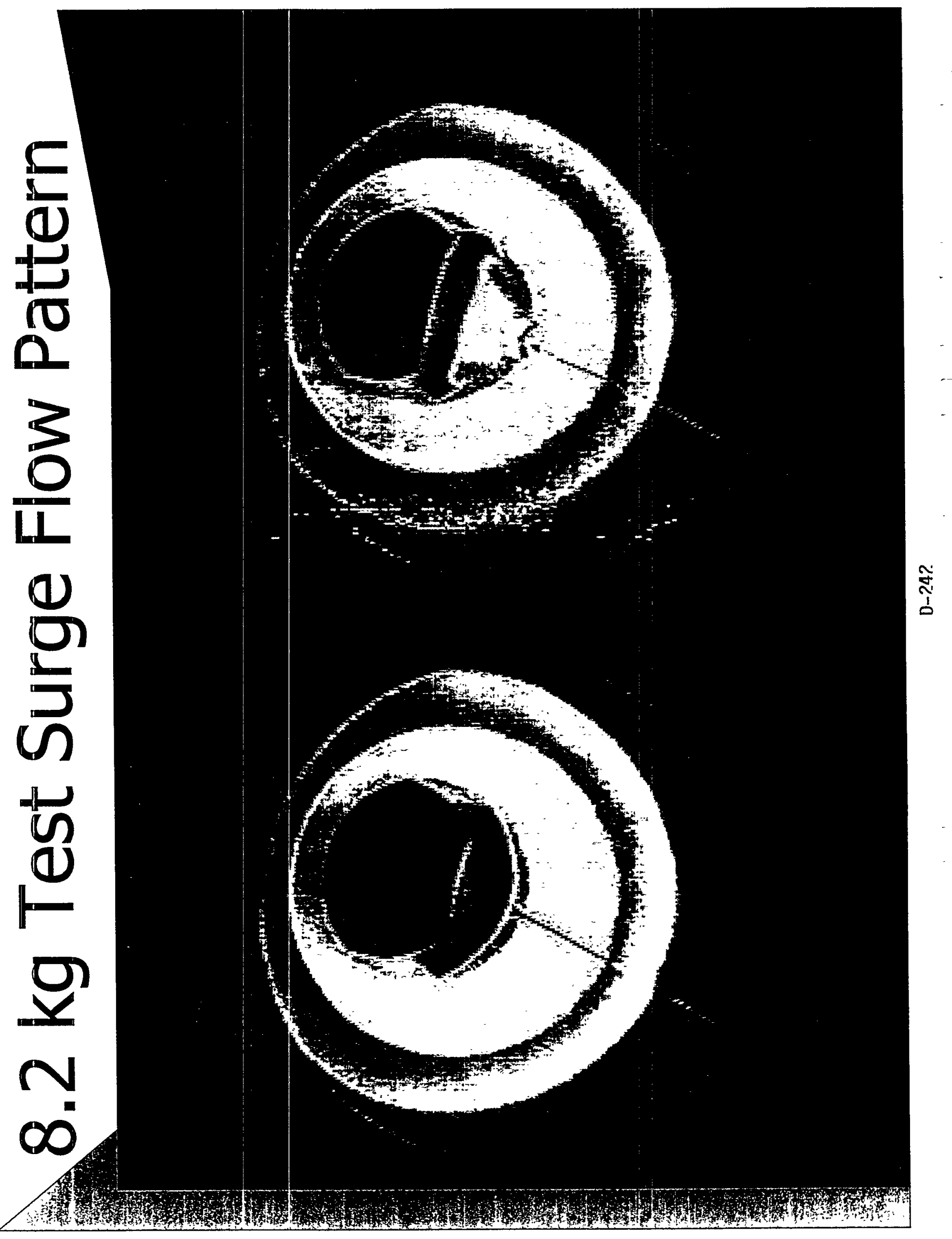




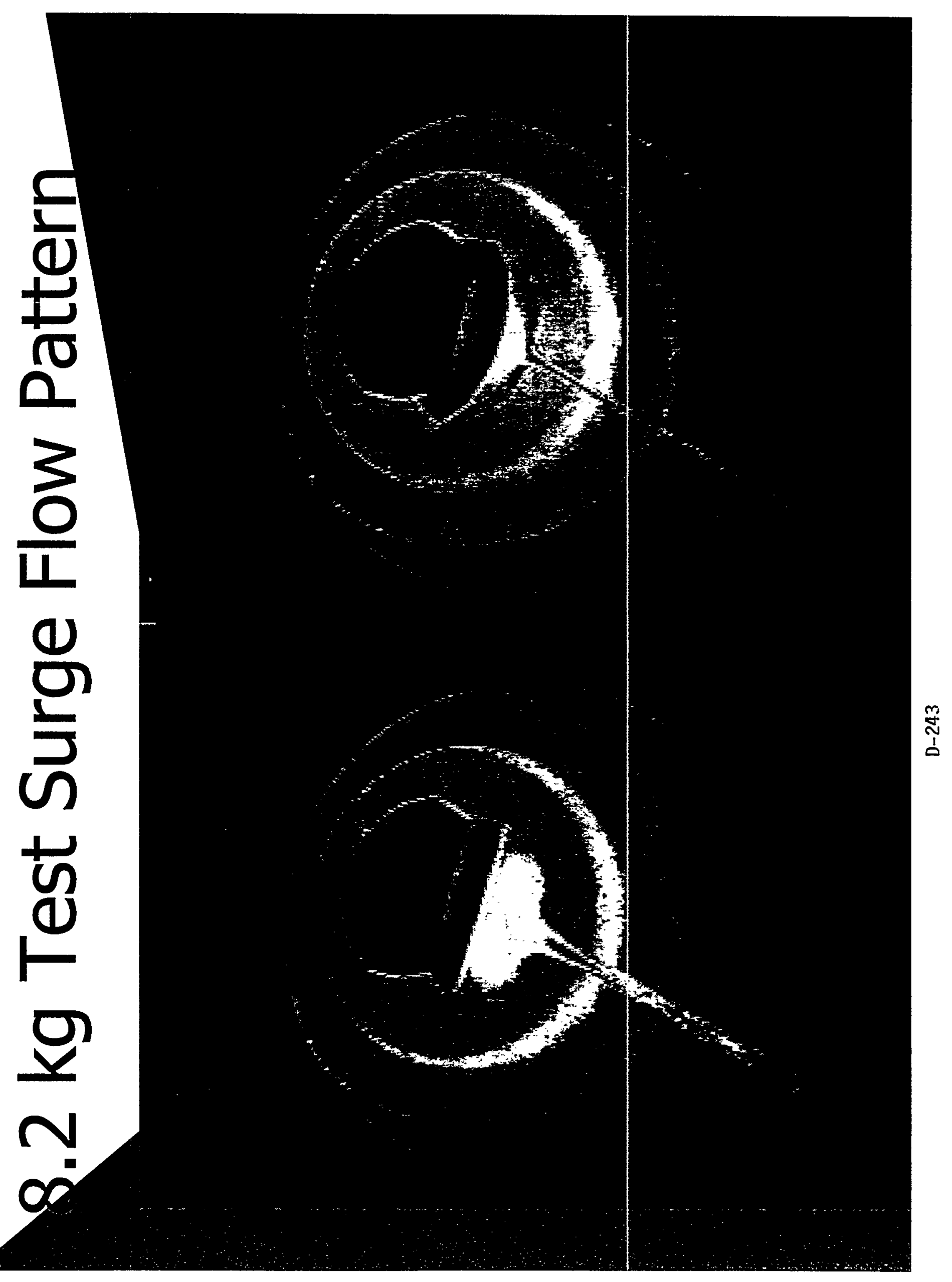



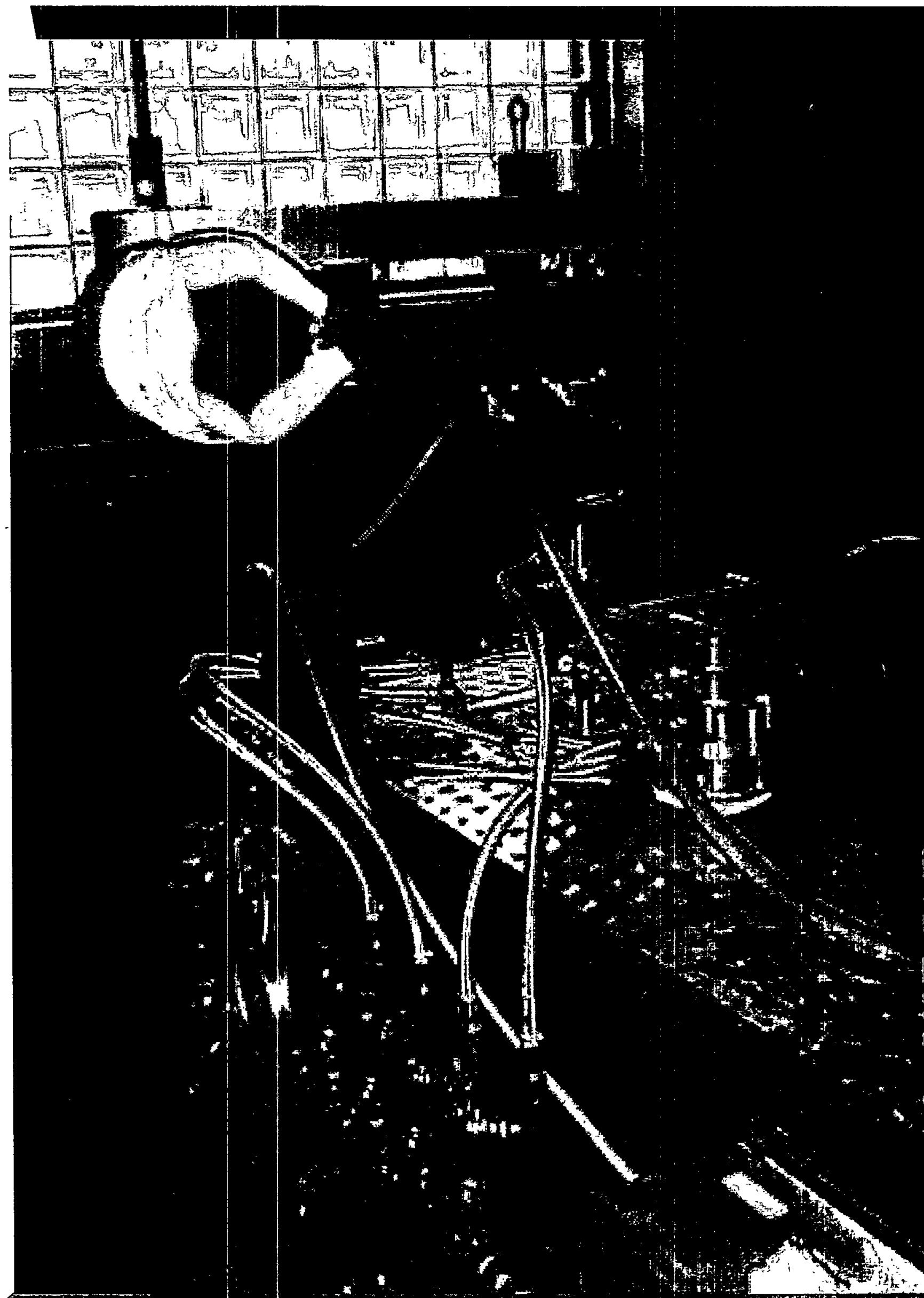

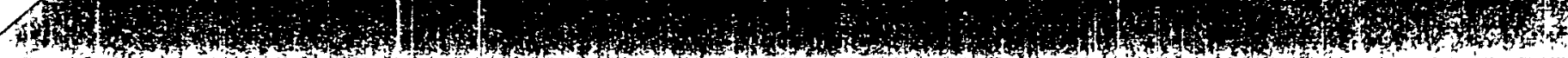




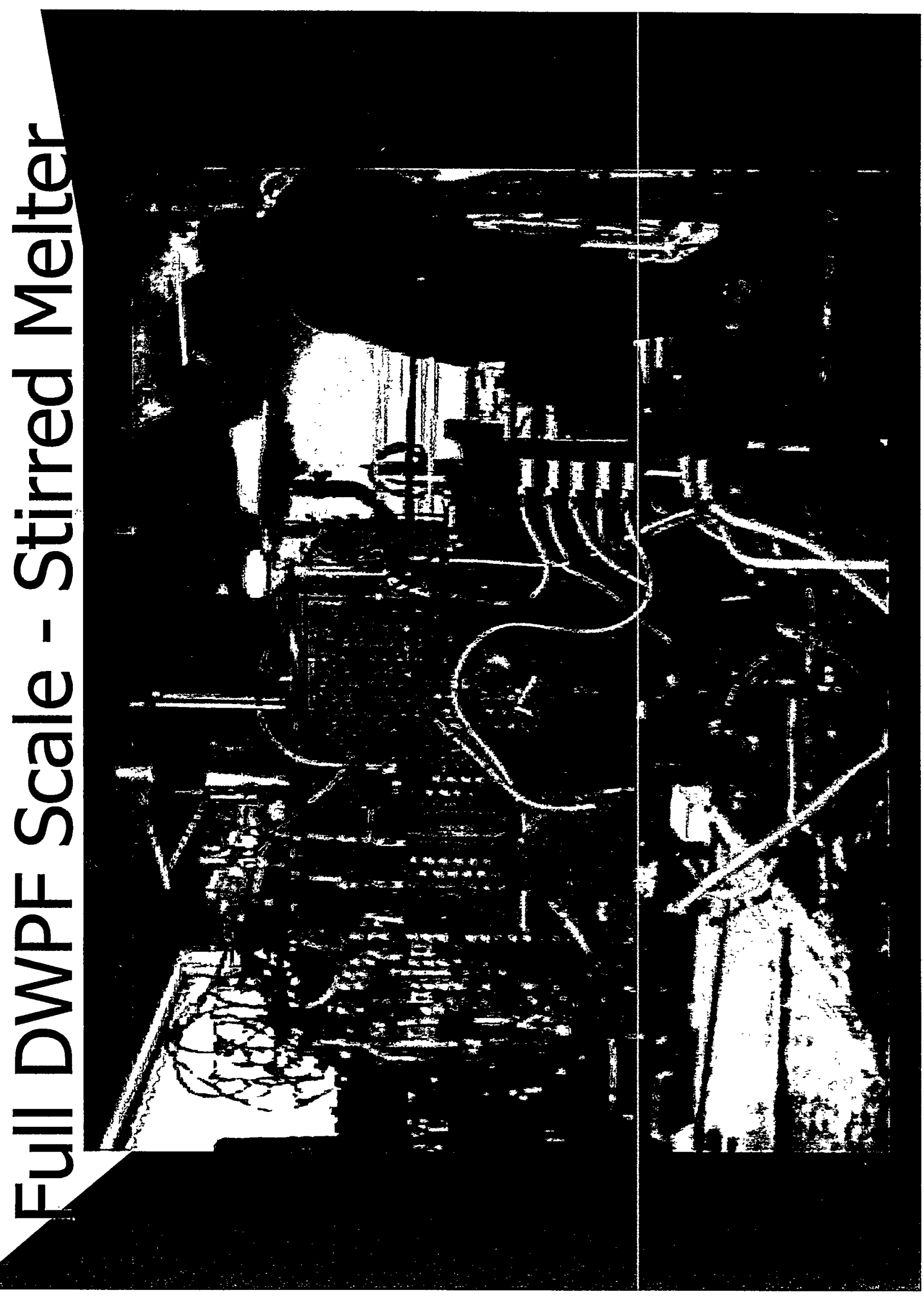




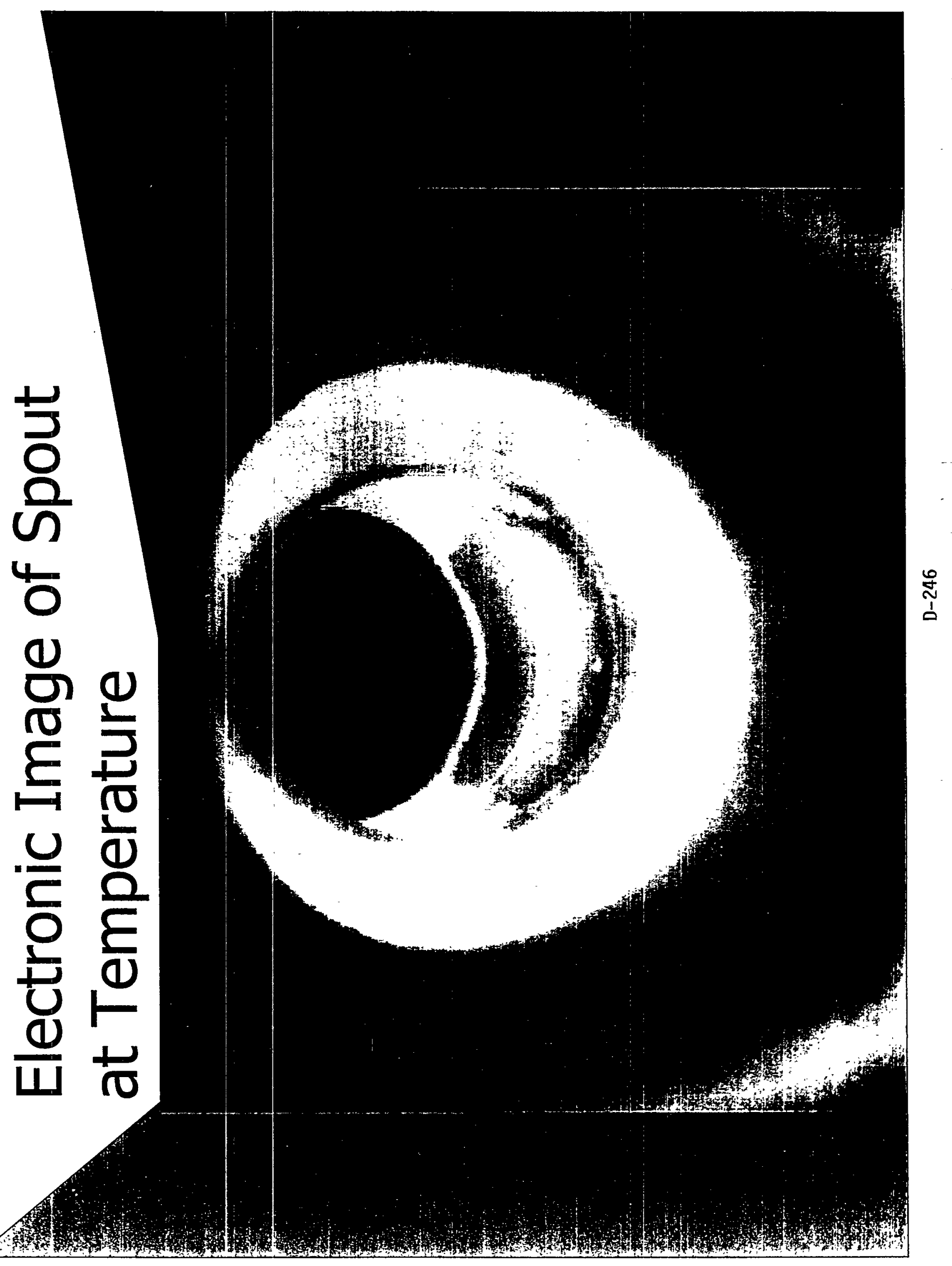




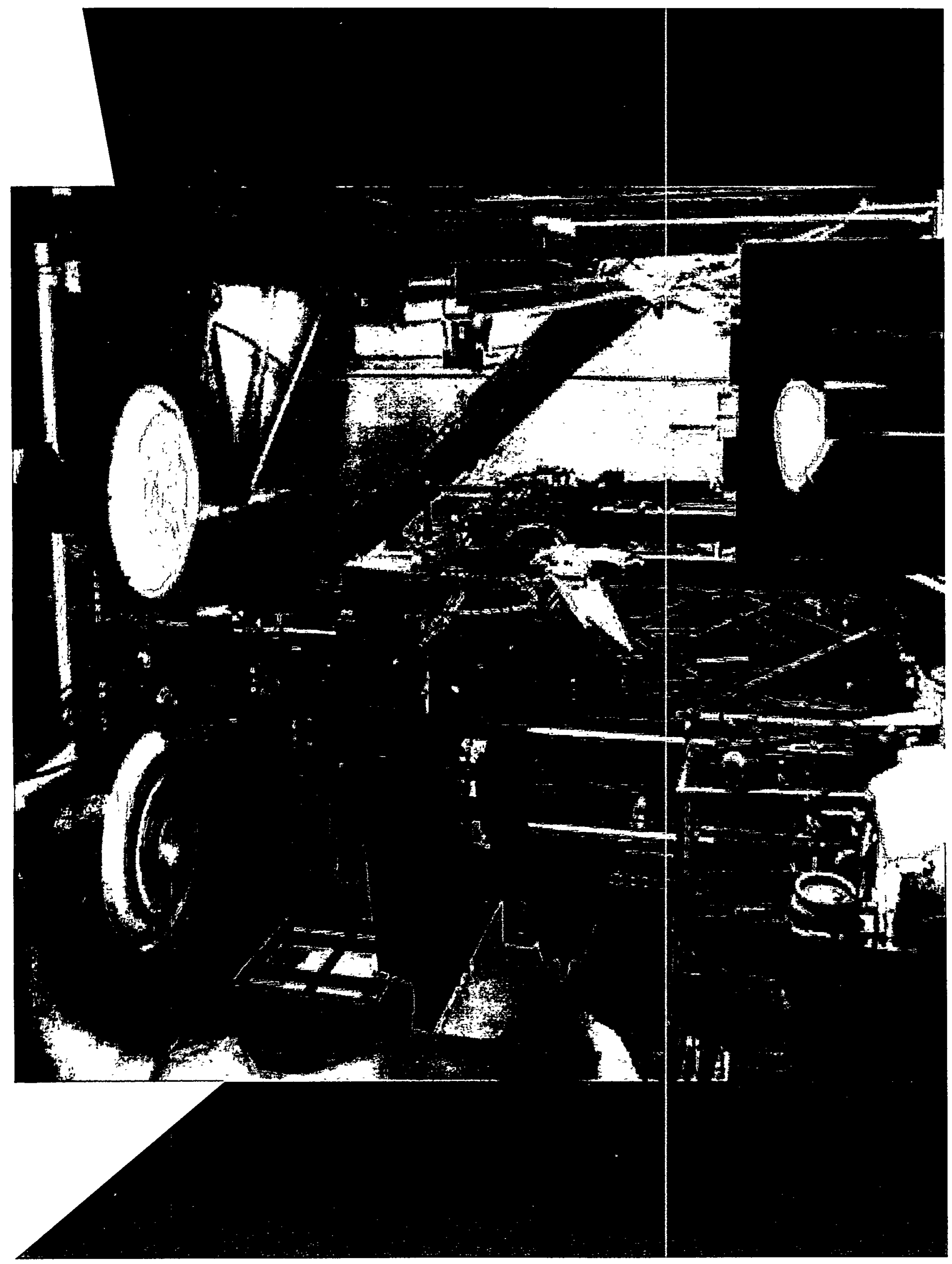




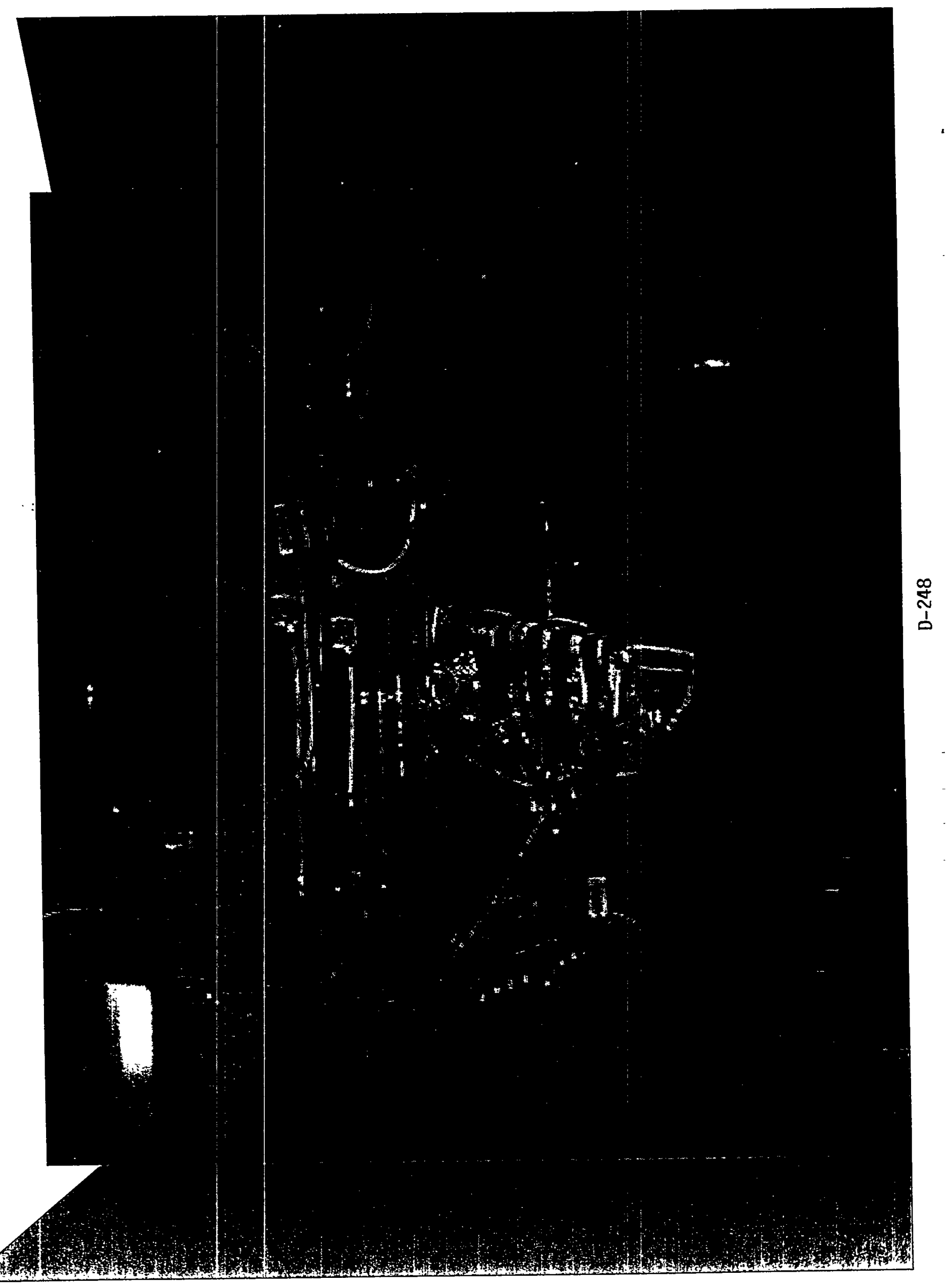




\title{
The Behavior and Effects of the Noble Metals in the Integrated DWPF Melter System
}

\author{
Mike E. Smith \\ Westinghouse Savannah River Company \\ Savannah River Technology Center \\ Aiken, SC 29808
}

Work done under Contract No. DE-AC09-96SR18500 with the U.S. Department of Energy 


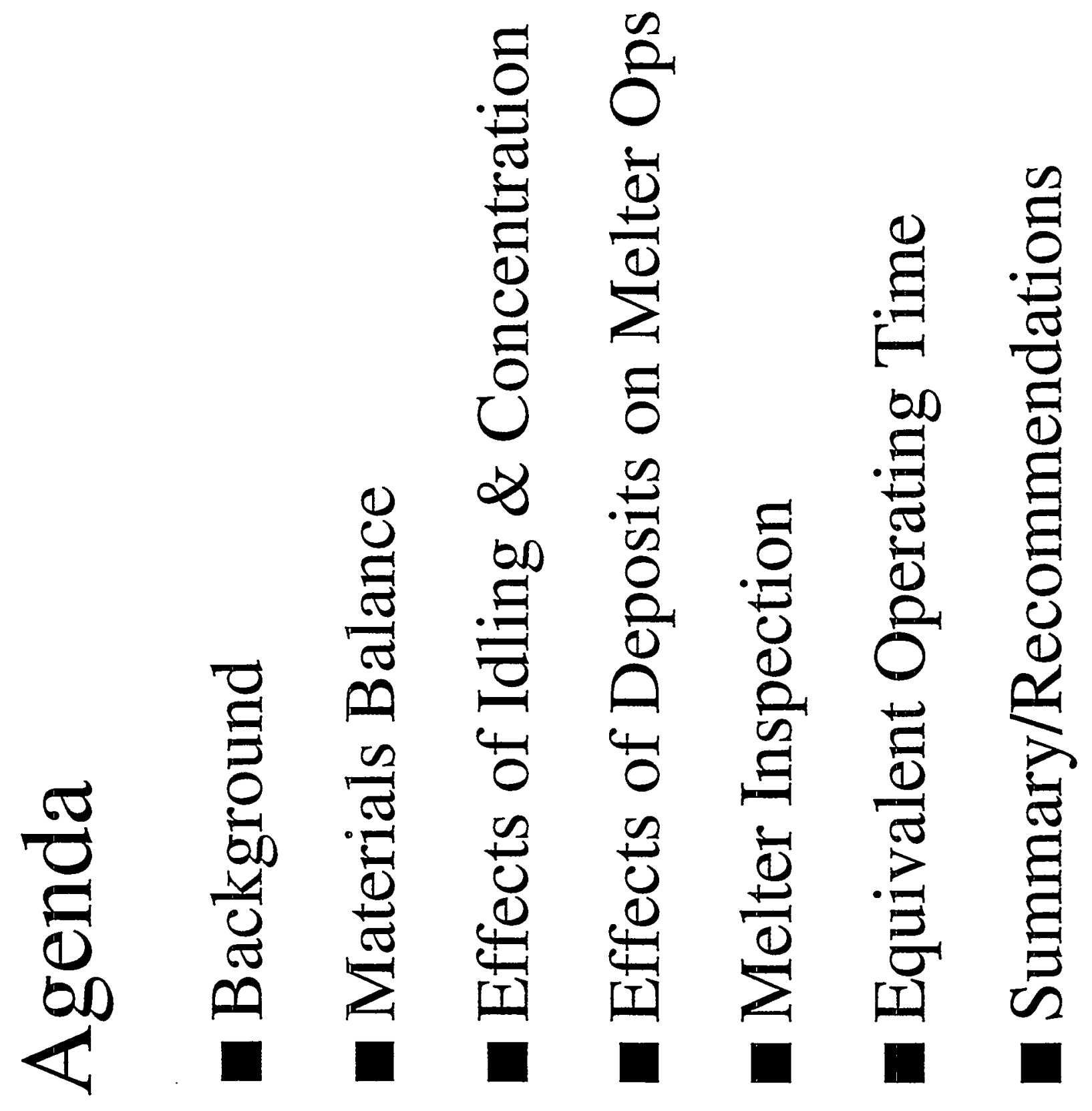

윰 


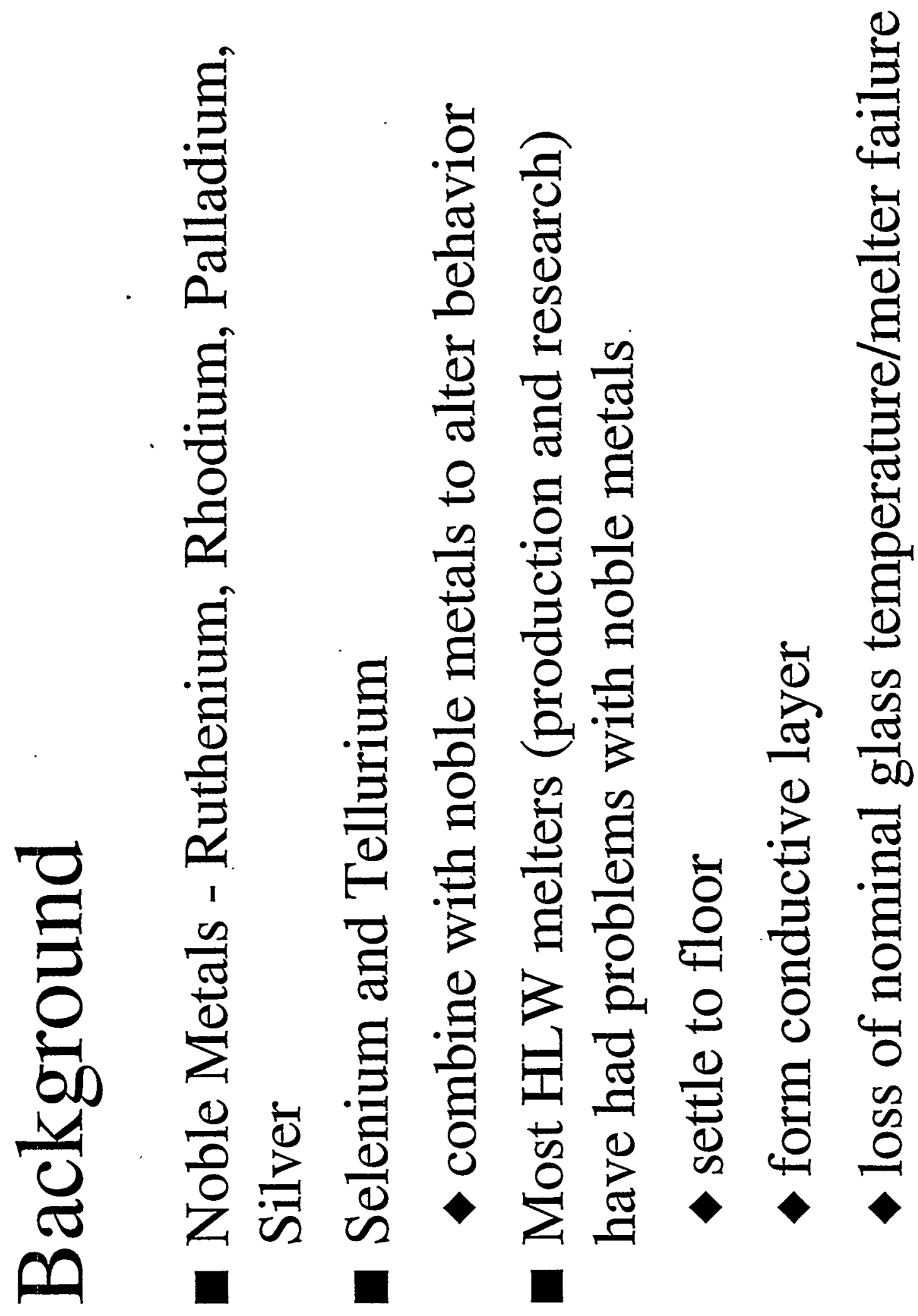



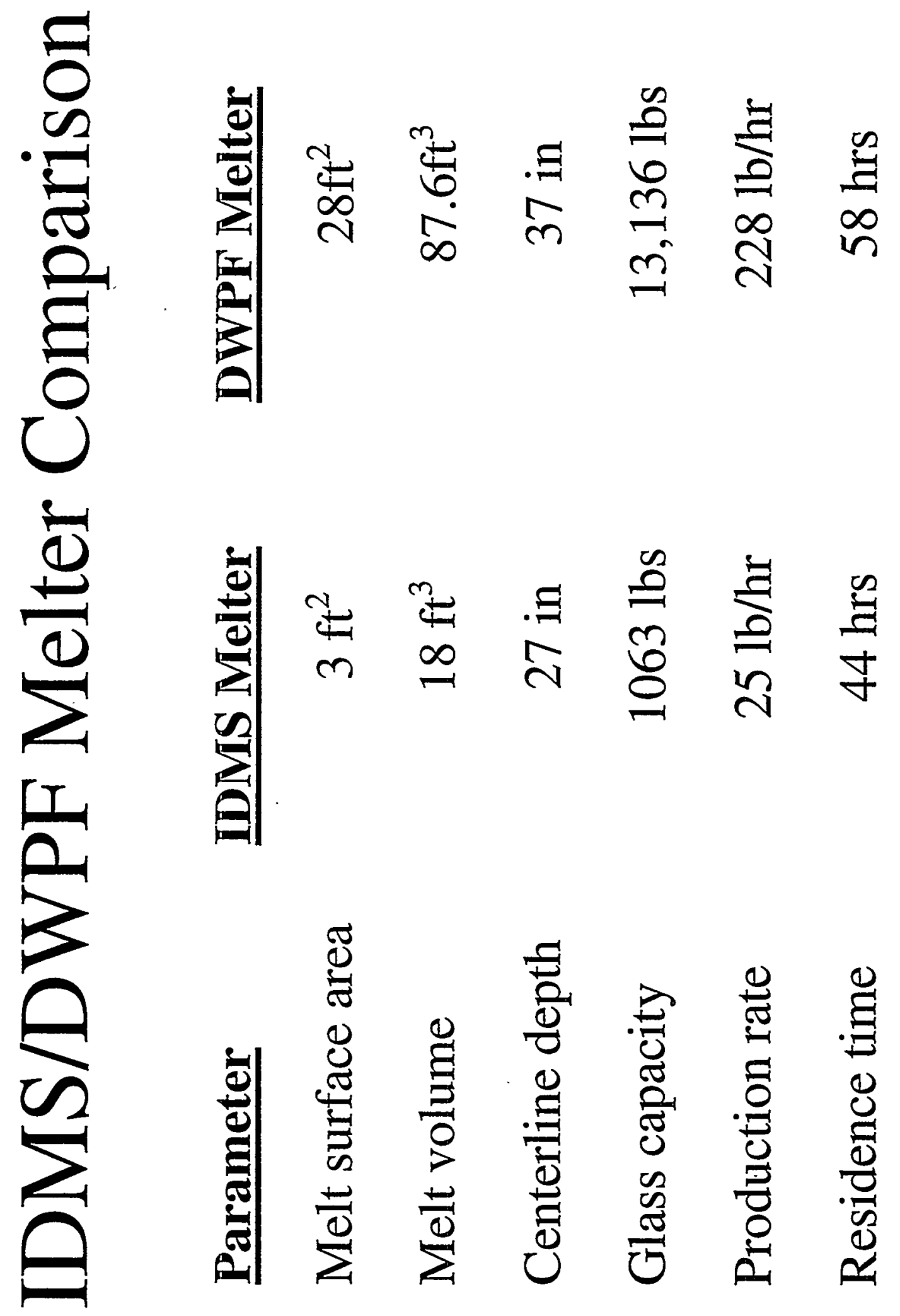


\section{Melter Electrode Designs}

Electrode Design

Upper surface area $\left(\mathrm{ft}^{2}\right)$

Lower surface area $\left(\mathrm{ft}^{2}\right)$

Electrode power/pair (kw) 20

Distance between

electrodes

Across melter (in)

Top and bottom (in)
IDMS

1.0

0.74

17.2

6.75
DWPF

9.49

11.00

80 


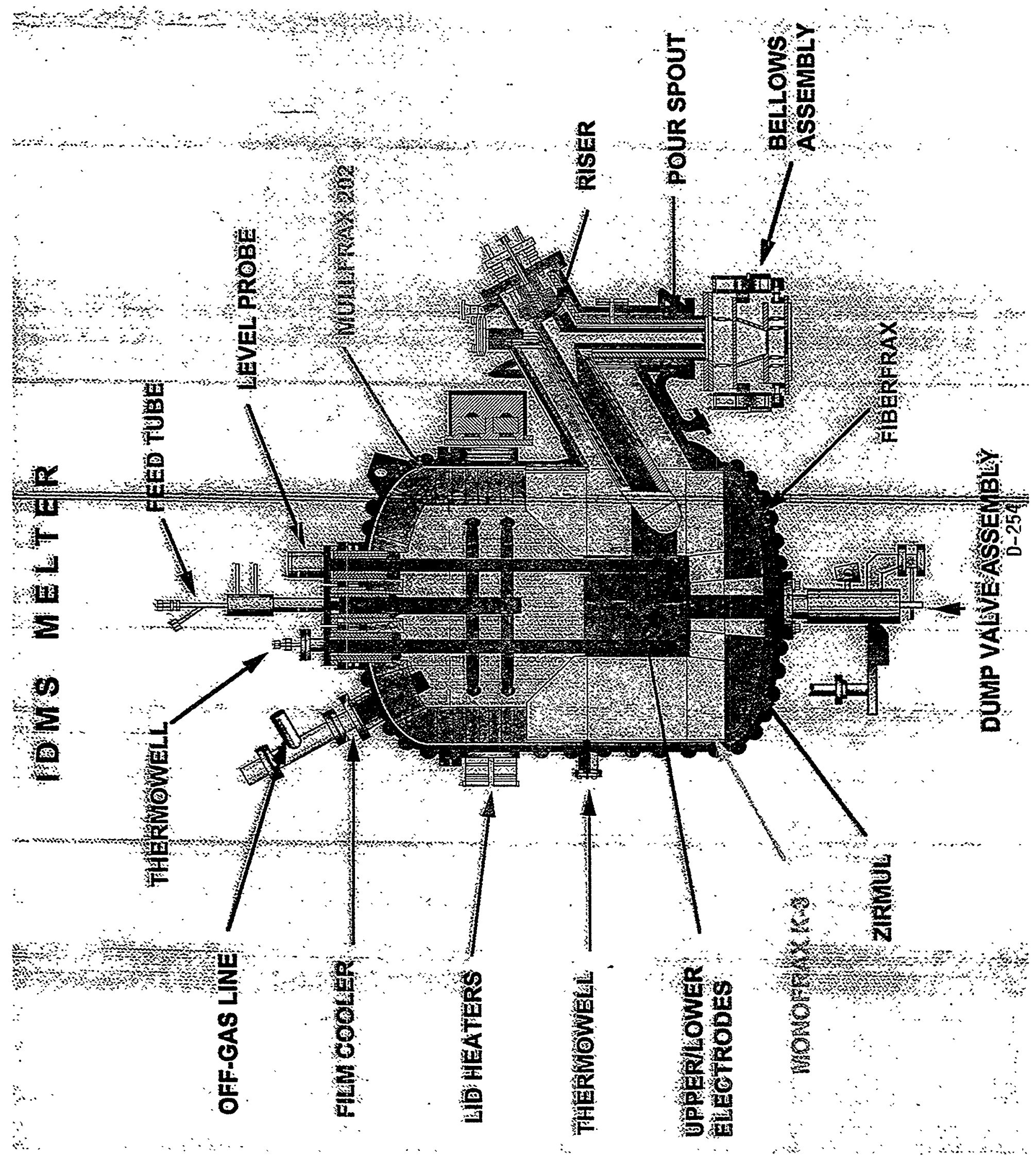




\section{Sludge Noble Metals Concentration}

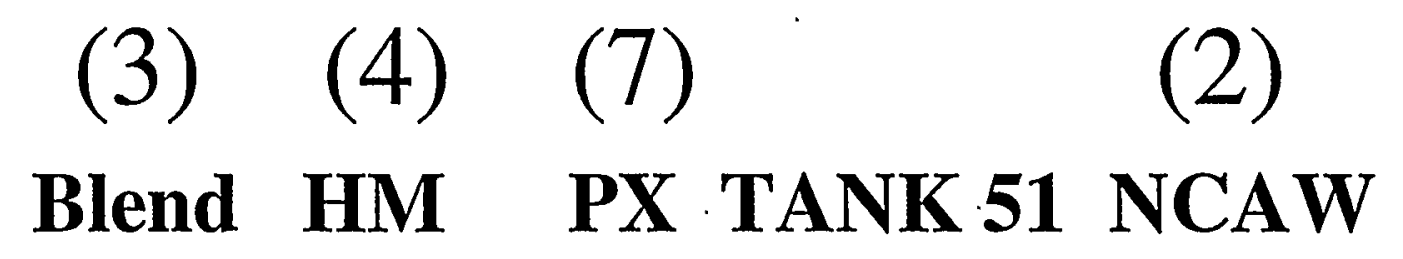

Element wt\% wt\% wt\% wt\% wt\%

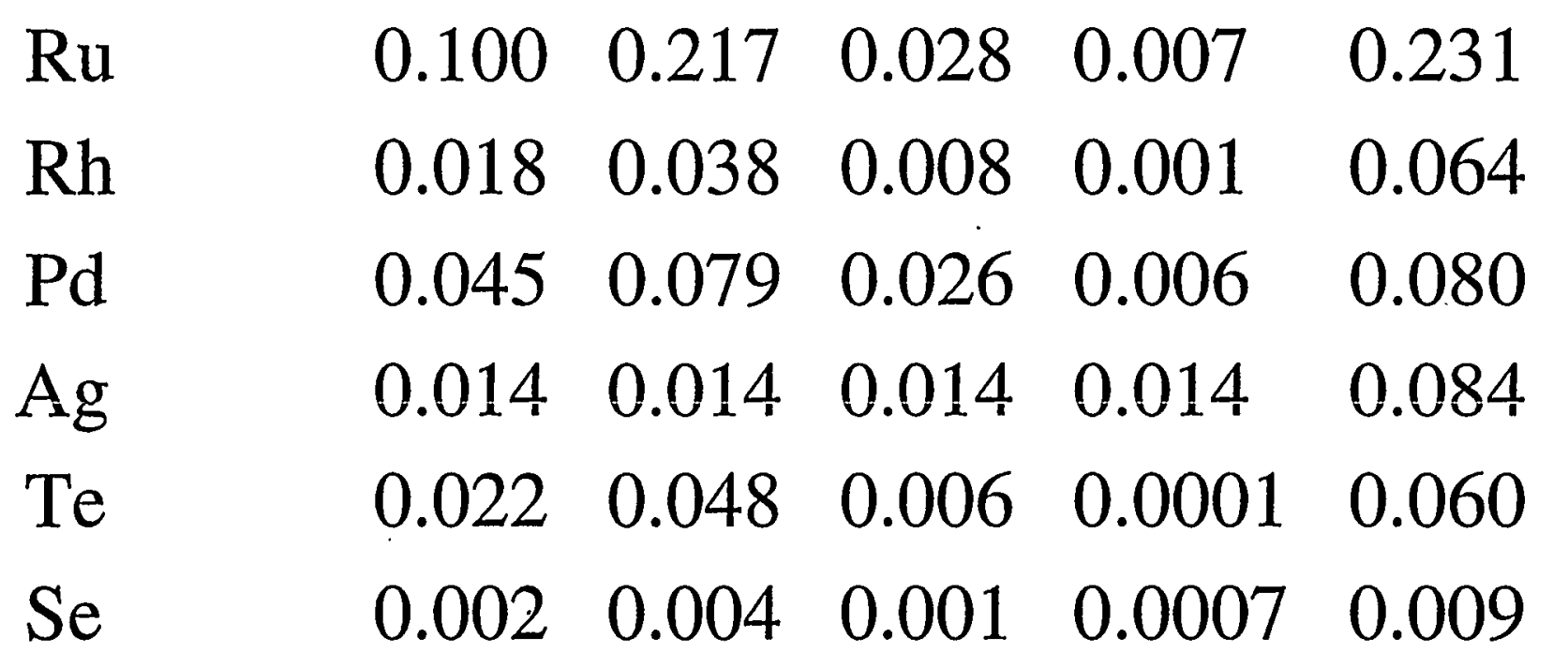

(\#) indicates number of IDMS runs 


\section{Additive Form of Noble Metals}

$\underline{\text { Element }}$

$\mathrm{Ru}$

$\mathrm{Rh}$

$\mathrm{Pd}$

$\mathrm{Ag}$

$\mathrm{Se}$

$\mathrm{Te}$
Form

Nitrosylruthenium Hydroxide

Rhodium Nitrate

Palladium Nitrate

Silver Nitrate

Selenium Oxide

Tellurium Oxide 


\section{Noble Metals Form/Size}

- Cold Cap

- RuO2 needles (20 microns/20-50 micron clusters)

- RuS2, Pd tellurides and selenides, AgI salts (1 micron)

E Off-Gas

- RuO2, spinels, insoluble Ag halide salts 


\section{Noble Metals Form/Size (cont.)}

- Glass Product

- mostly RuO2 clusters (<10 microns)

- $\mathrm{RuO} 2$ with (Ni,Mn)Fe2O4 \& (Ni,Mn)Cr04 spinels 


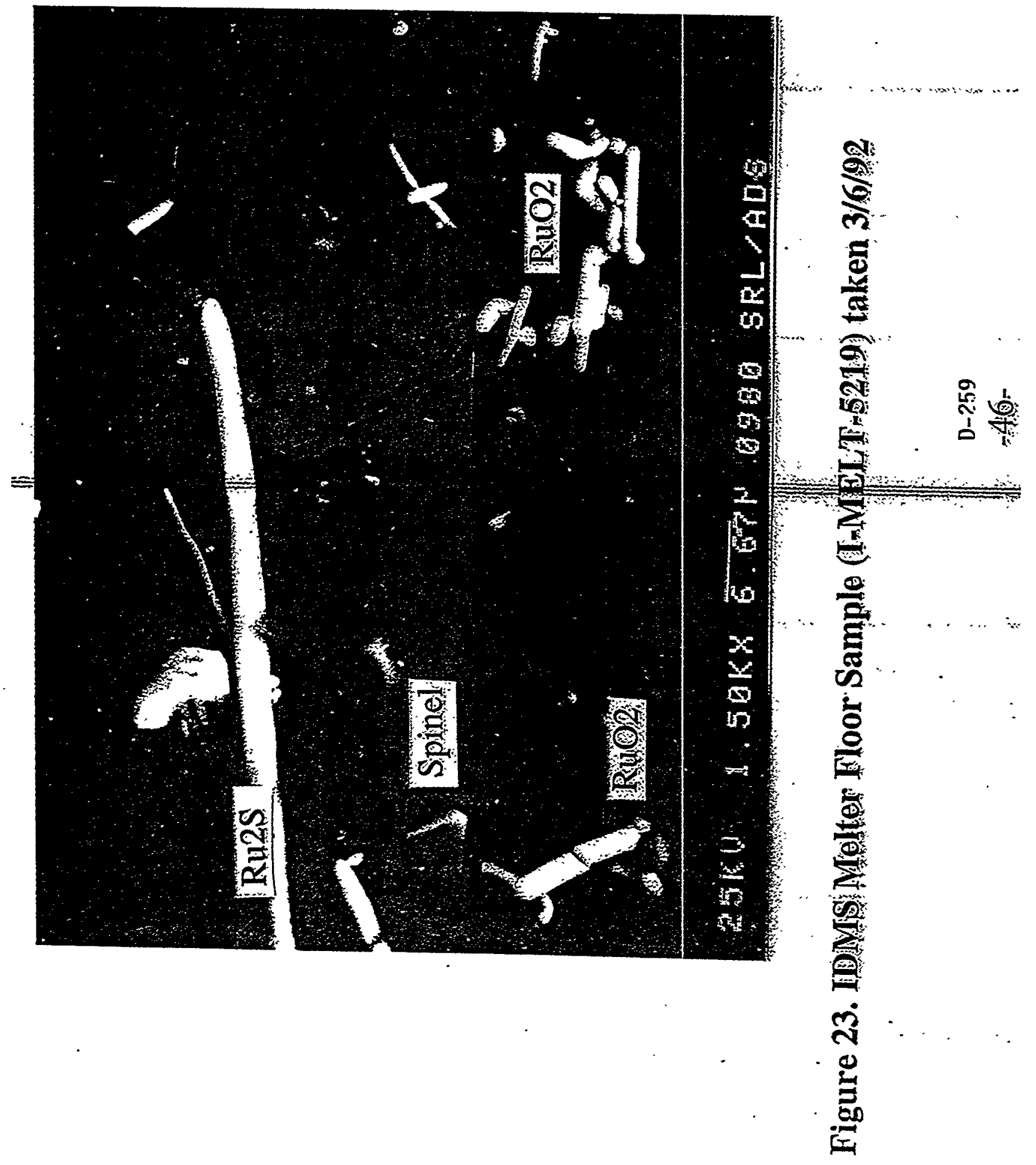




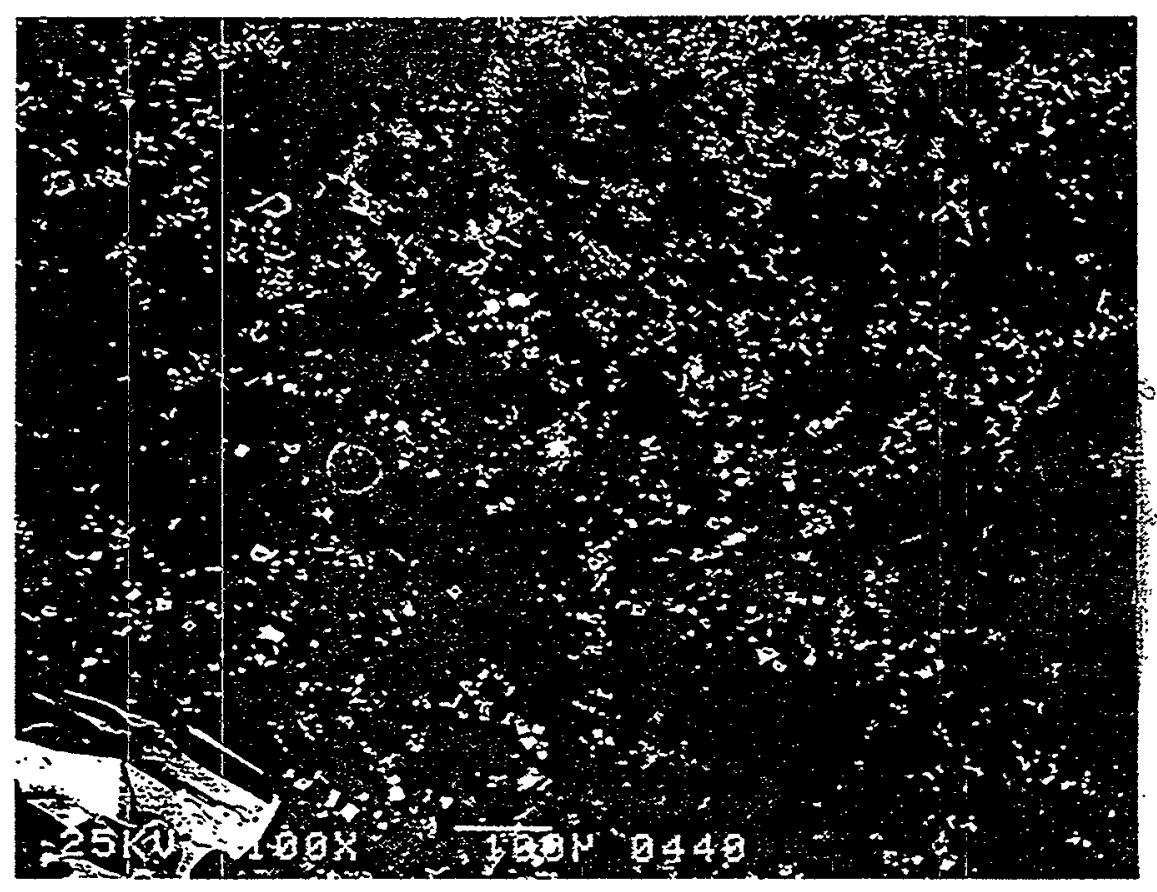

Figure 18. EDMS Melter Floor Sample (I-MELT-4790) taken 10/15/91

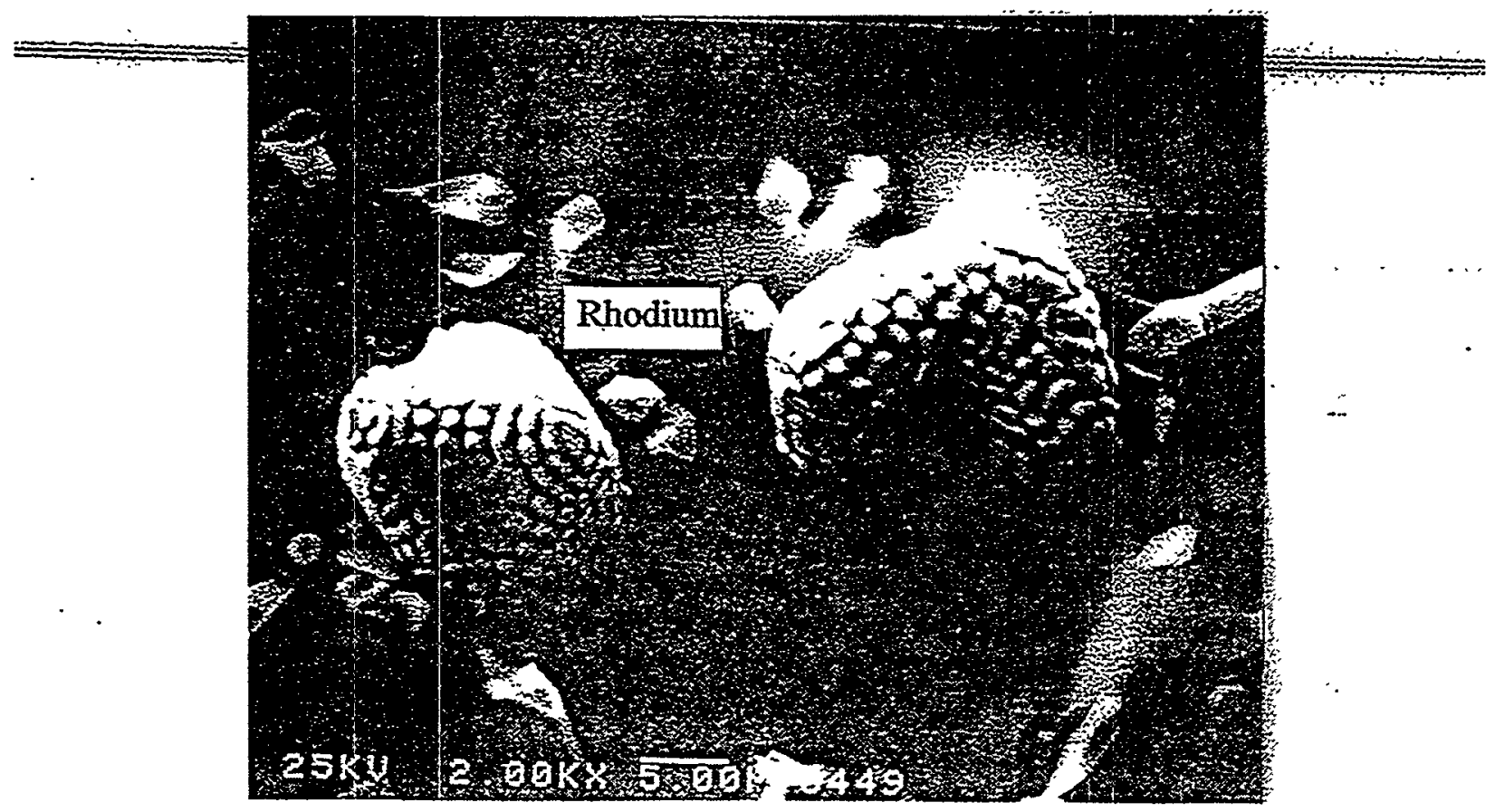

Figure 19. IDMS Melter Floor Sample (I-MELT-4790) taken 10/15/91 


\section{Noble Metals Material Balances}

- Compared amount fed versus amount exiting melter

- Amounts retained

- $\mathrm{Ru}-35 \%$

- $\mathrm{Rh}-21 \%$

- Pd - less than $10 \%$

- Ag - $0 \%$ 


\section{Ruthenium Material Balance}

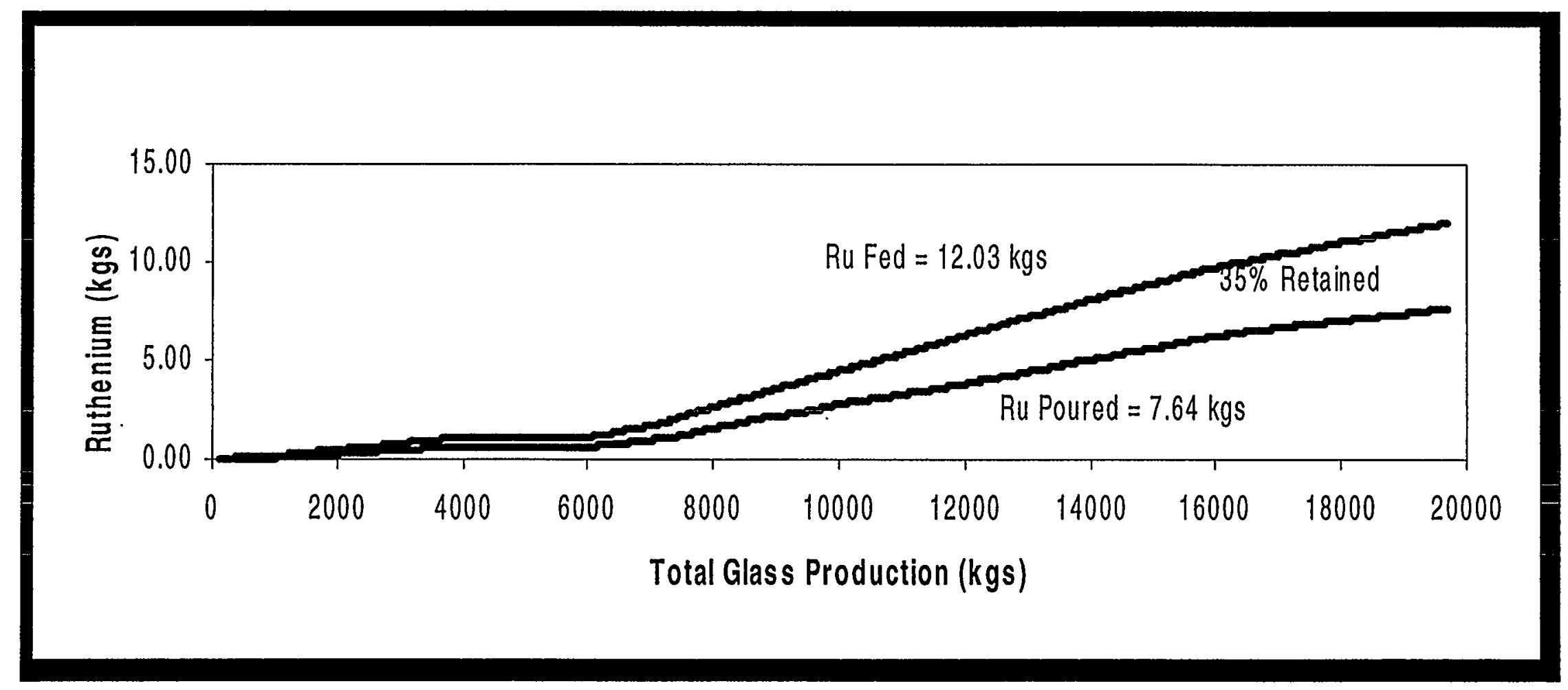



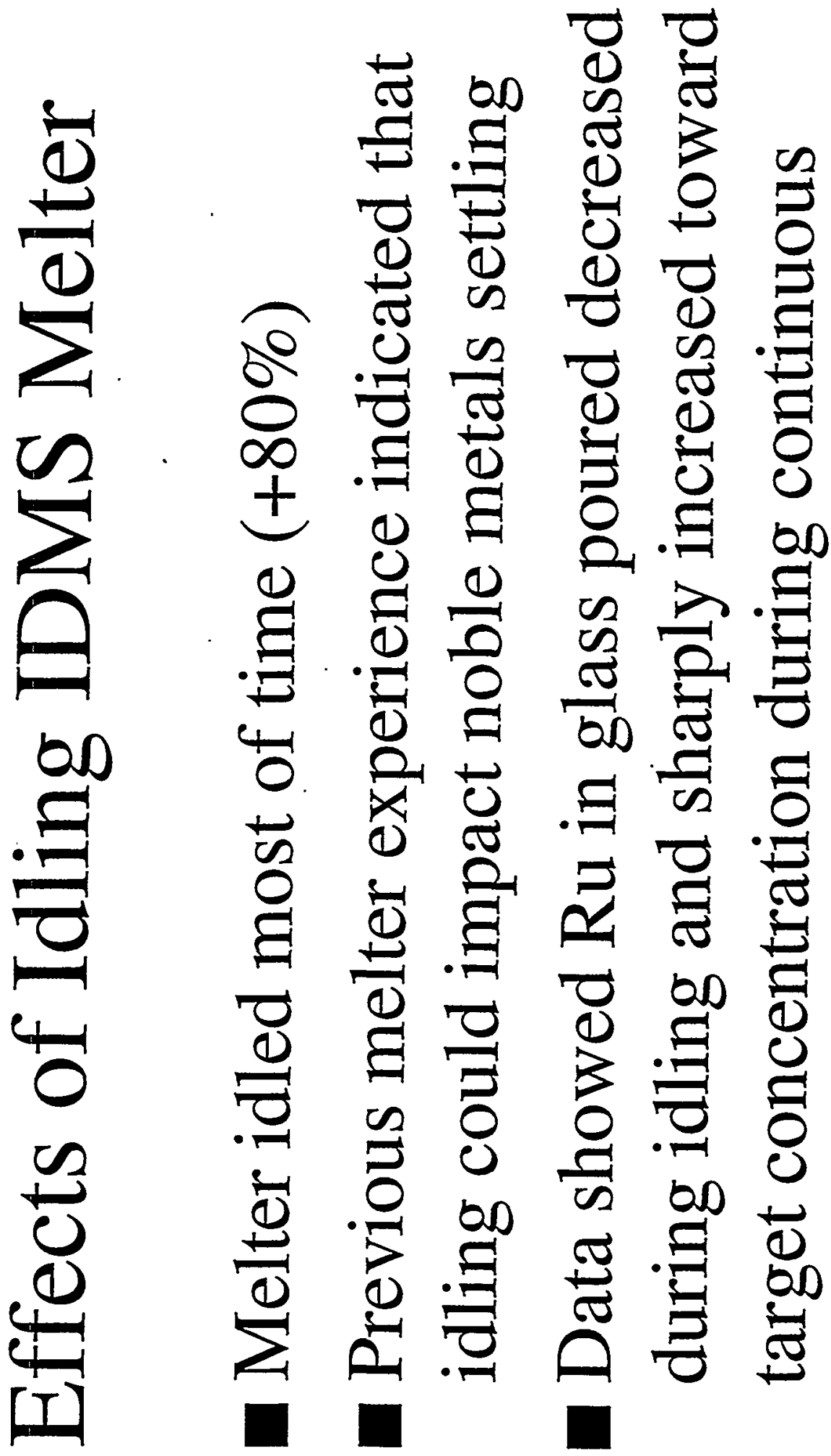

$$
\text { I O D o }
$$

থิ

.$+ \exists$ 。 0

() 仓 o

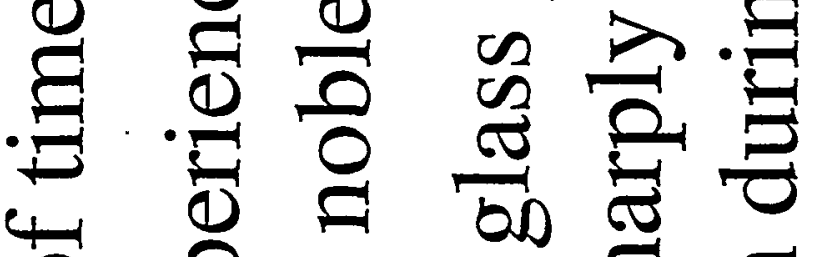

․

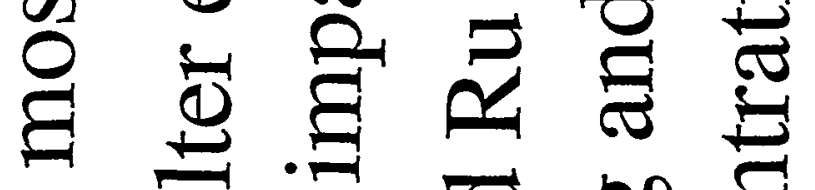

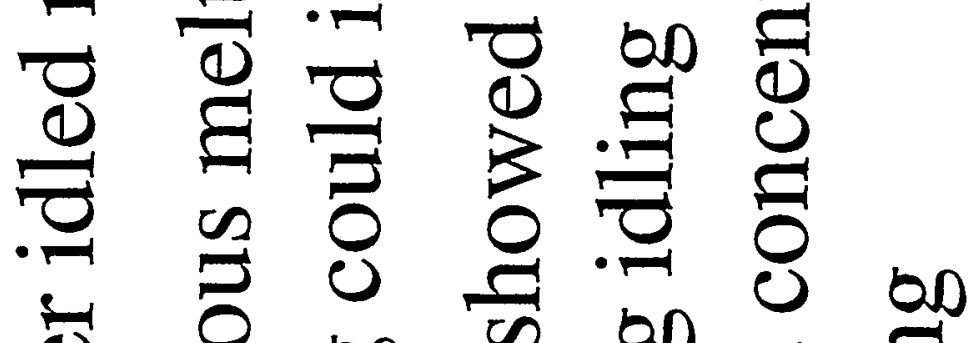

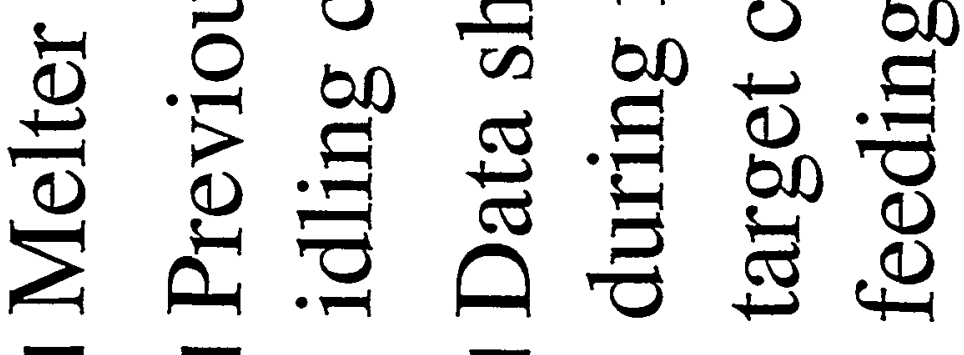




\section{$\mathrm{Ru}$ Concentration in Glass versus Idling Time}

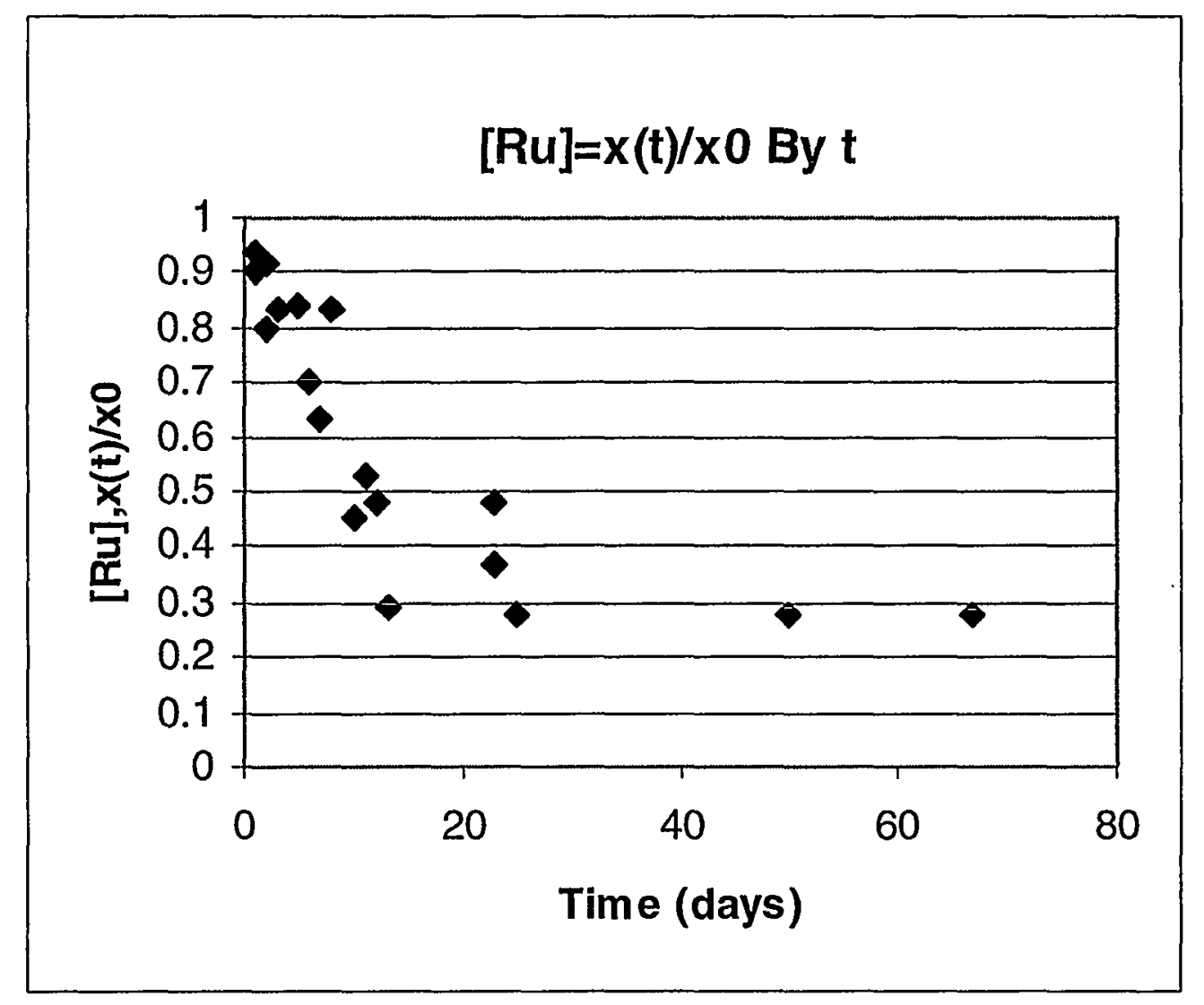




\section{Effects of Concentration}

- Greatest increase in amount of glass in floor samples (0.02 to $4.7 \mathrm{wt} \% \mathrm{Ru})$ occurred when noble metals in feed increased from Blend to HM levels

- Occurred even though idling time relatively short

- Agrees with Research Scale Melter PNNL data (non-linear relationship) 


\section{Effects of Deposition on IDMS Melter Operation}

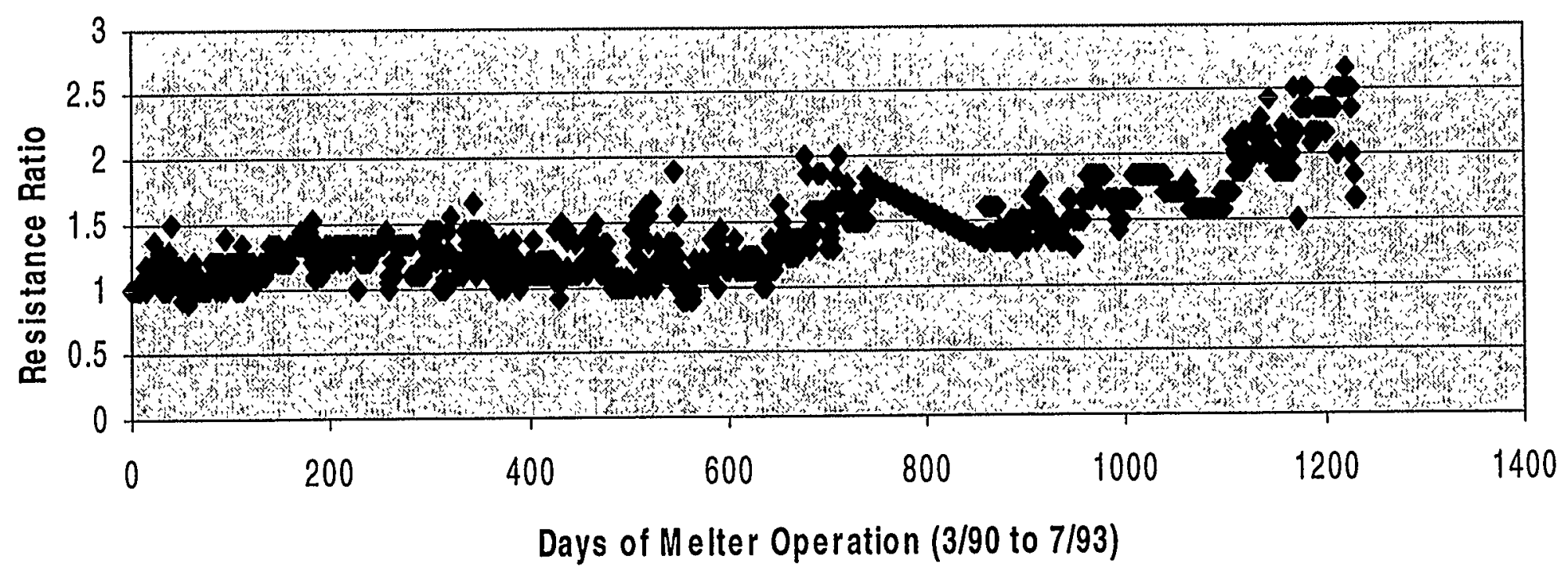




\section{IDMS Melter Post Shutdown Inspection}

- Bottom core samples had:

- 27 to 66 wt \% spinel

- 0.16 to $7.74 \mathrm{wt} \% \mathrm{Ru}(\mathrm{RuO} 2)$

$\bullet 0.026$ to $1.21 \mathrm{wt} \% \mathrm{Rh}$

- Five $\mathrm{cm}$ of material lost from bottom face of lower electrodes

- probably due to high current densities

- detailed metallurgical examination not done 


\section{Wt \% of Spinel \& Noble Metals}

\begin{tabular}{|c|c|c|c|c|}
\hline Sample & Spinel Wt \% & $\underline{\mathrm{Ru} W t} \%$ & Rh Wt\% & Pd Wt \% \\
\hline 1 & 42 & 0.33 & 0.078 & 0.68 \\
\hline 2 & 66 & 1.12 & 0.026 & 0.062 \\
\hline 3 & 33 & 5.37 & 0.069 & 0.041 \\
\hline 4 & 29 & 7.74 & 1.21 & 0.066 \\
\hline 5 & 27 & 5.66 & 1.00 & 0.160 \\
\hline 6 & 51 & 1.19 & 0.210 & 0.083 \\
\hline 7 & 48 & 0.16 & 0.062 & 0.075 \\
\hline 8 & 27 & 0.41 & 0.130 & 0.031 \\
\hline 9 & 36 & 1.60 & 0.39 & 0.14 \\
\hline 10 & 44 & 1.7 & 0.410 & 0.170 \\
\hline
\end{tabular}




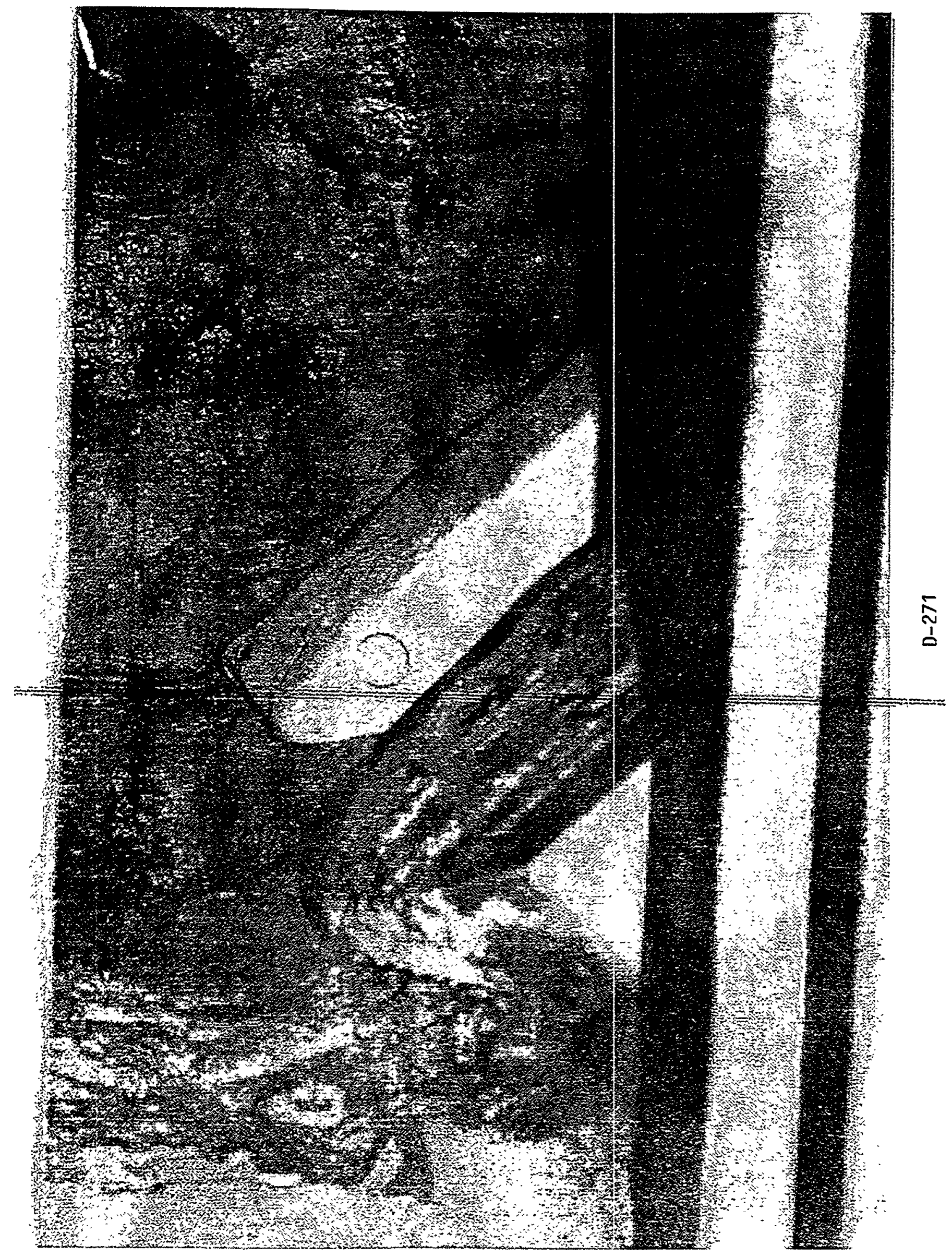




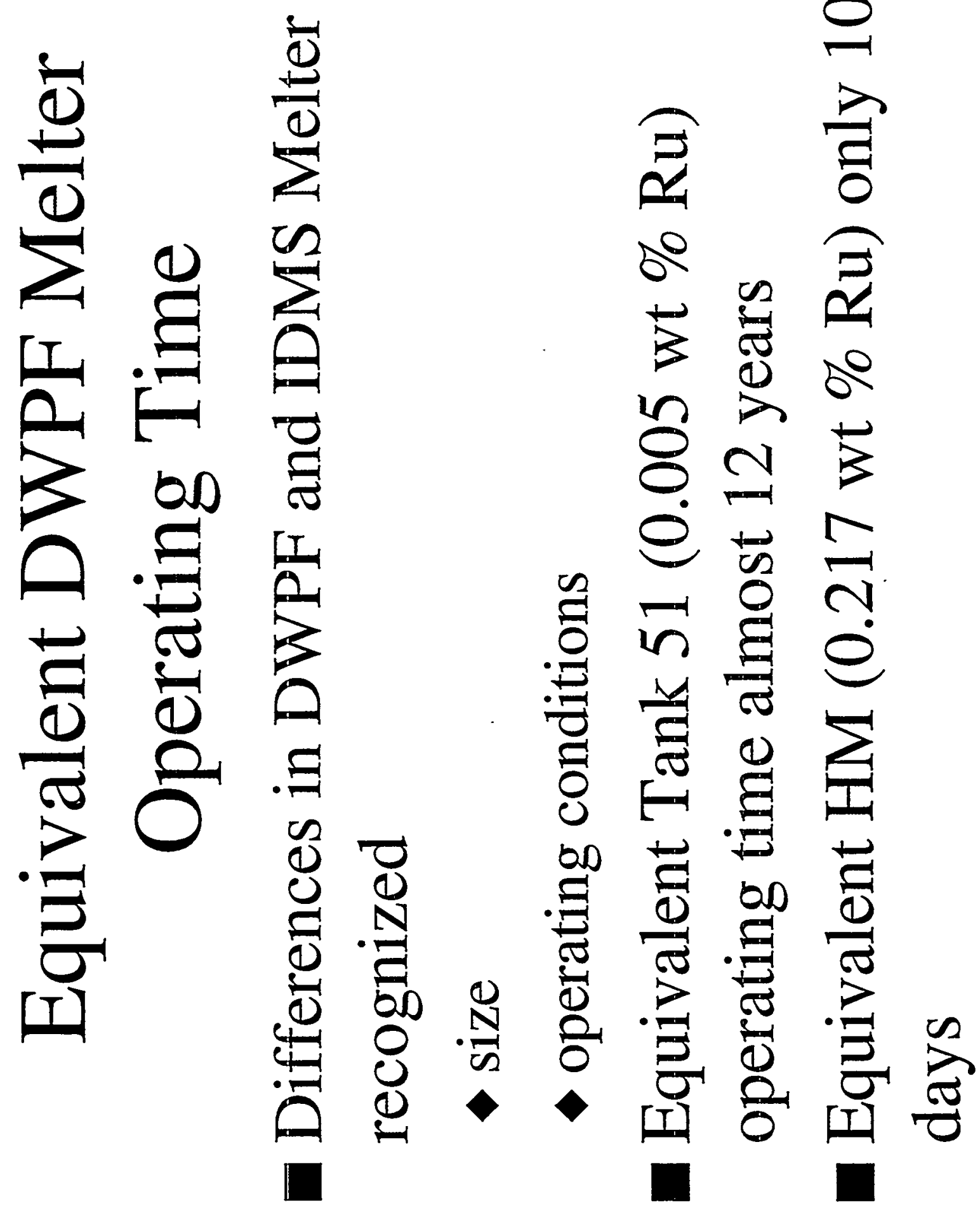

$\stackrel{N}{N}$ 


\section{Summary/Recommendations}

- Noble metals negatively impacted melter

- Settling much less during feeding/pouring

- Settling heavily influenced by noble metals concentration in feed

- $35 \%$ of $\mathrm{Ru}, 21 \%$ of $\mathrm{Rh}, 10 \%$ of $\mathrm{Pd}$, and $0 \%$ of $\mathrm{Ag}$ retained in melter

- Equivalent Tank 51 IDMS Melter operation time was 12 years, only 100 days for HM

- Modifications to DWPF Melter and blending of DWPF sludge tanks should be considered 


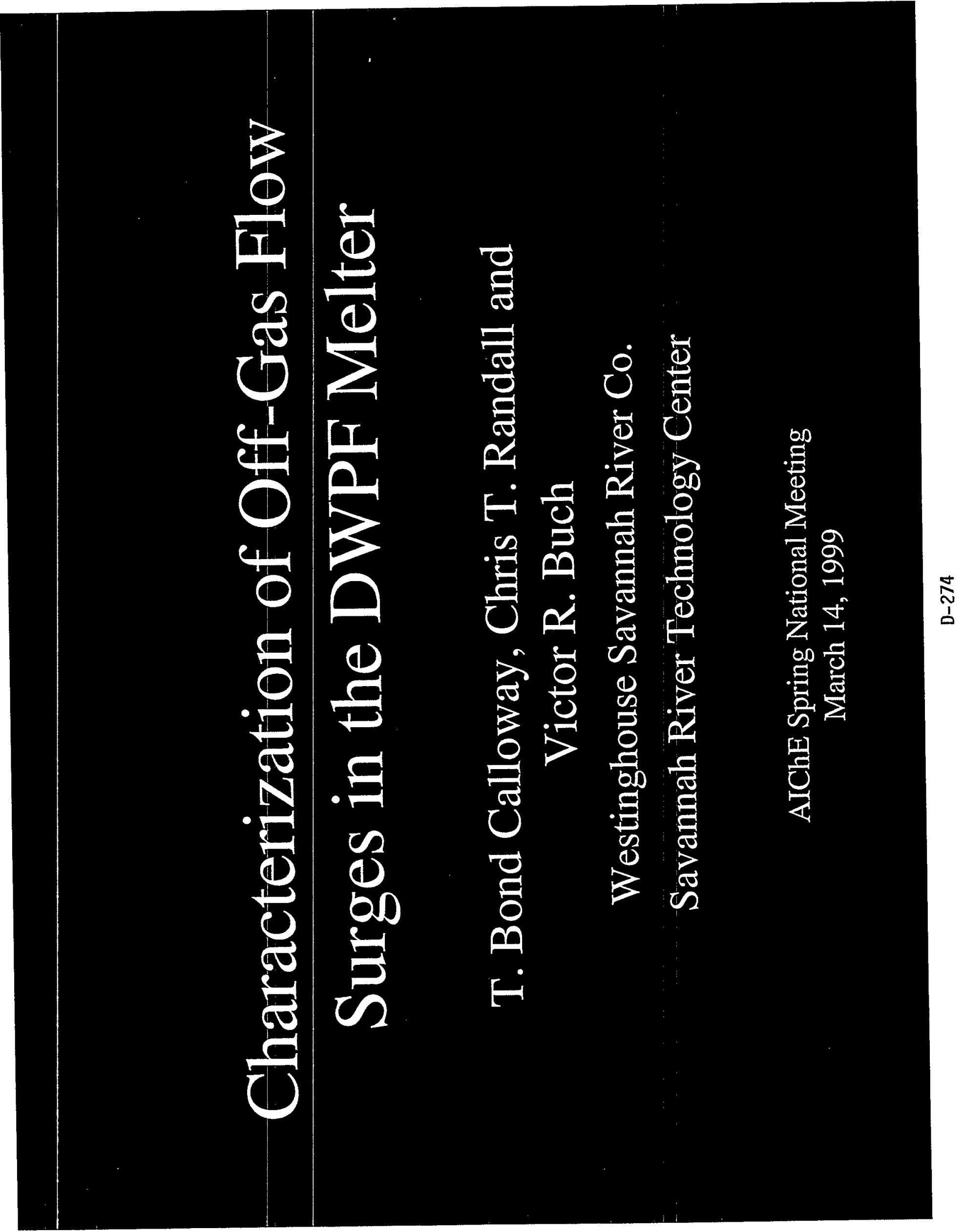




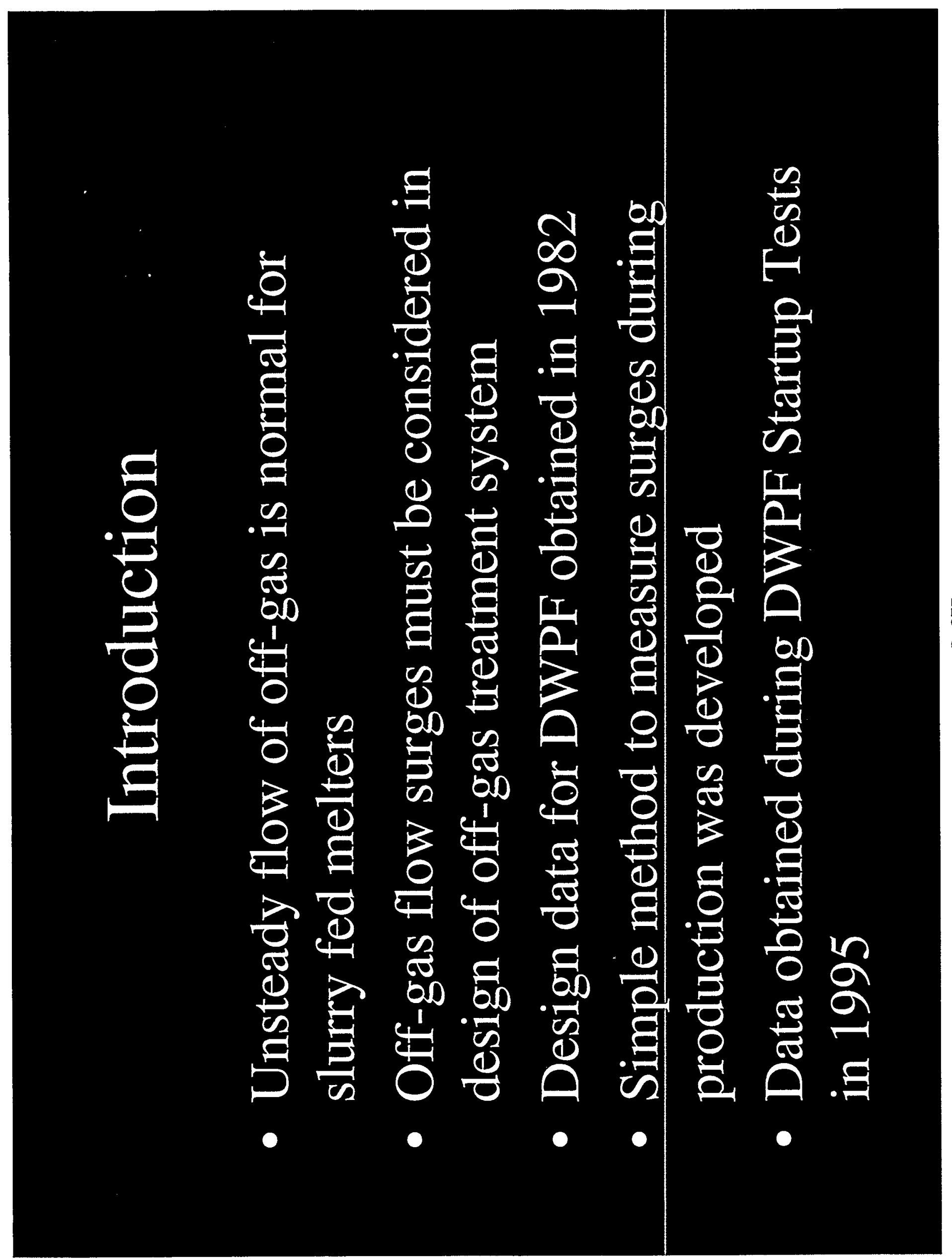




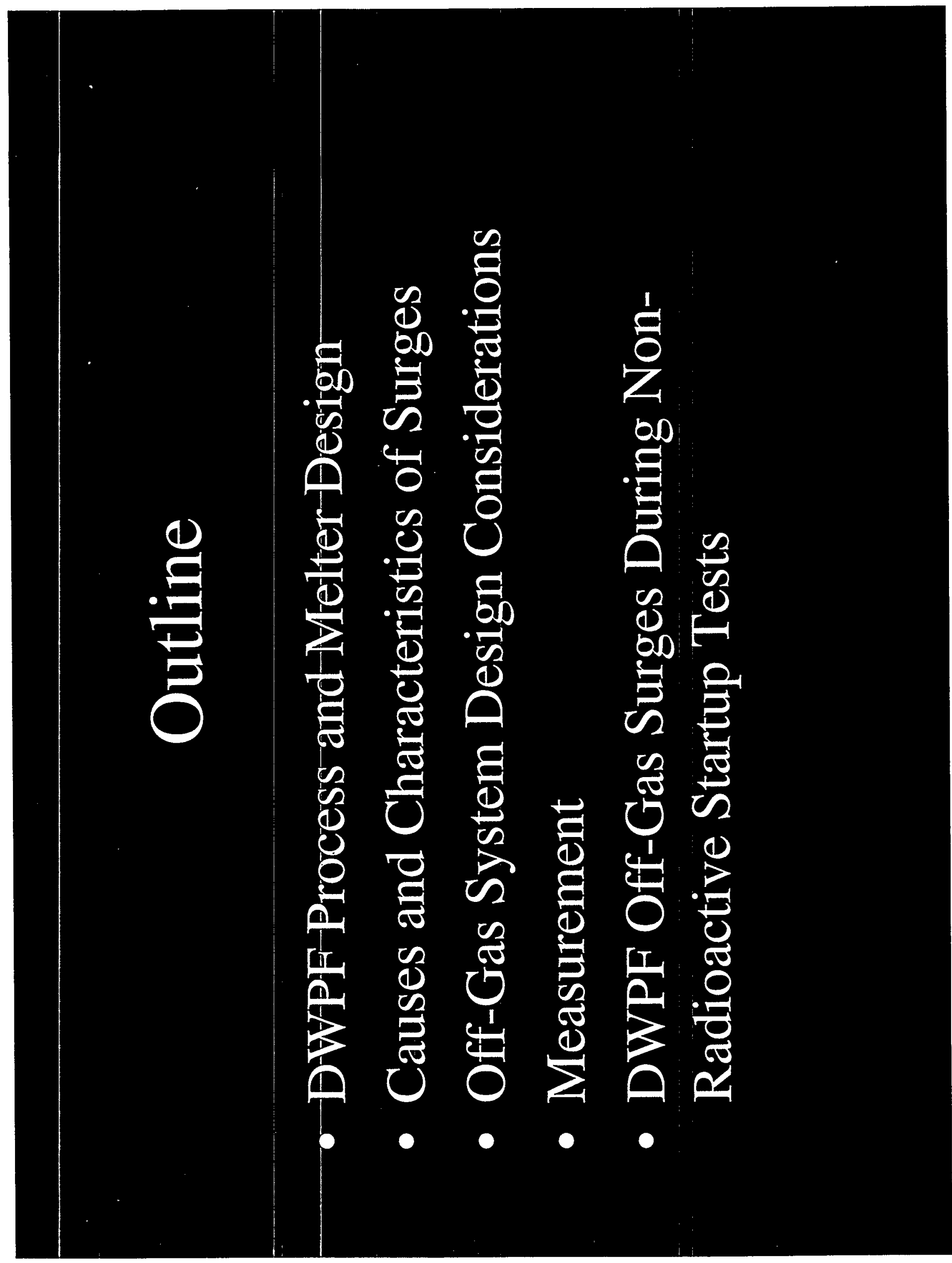




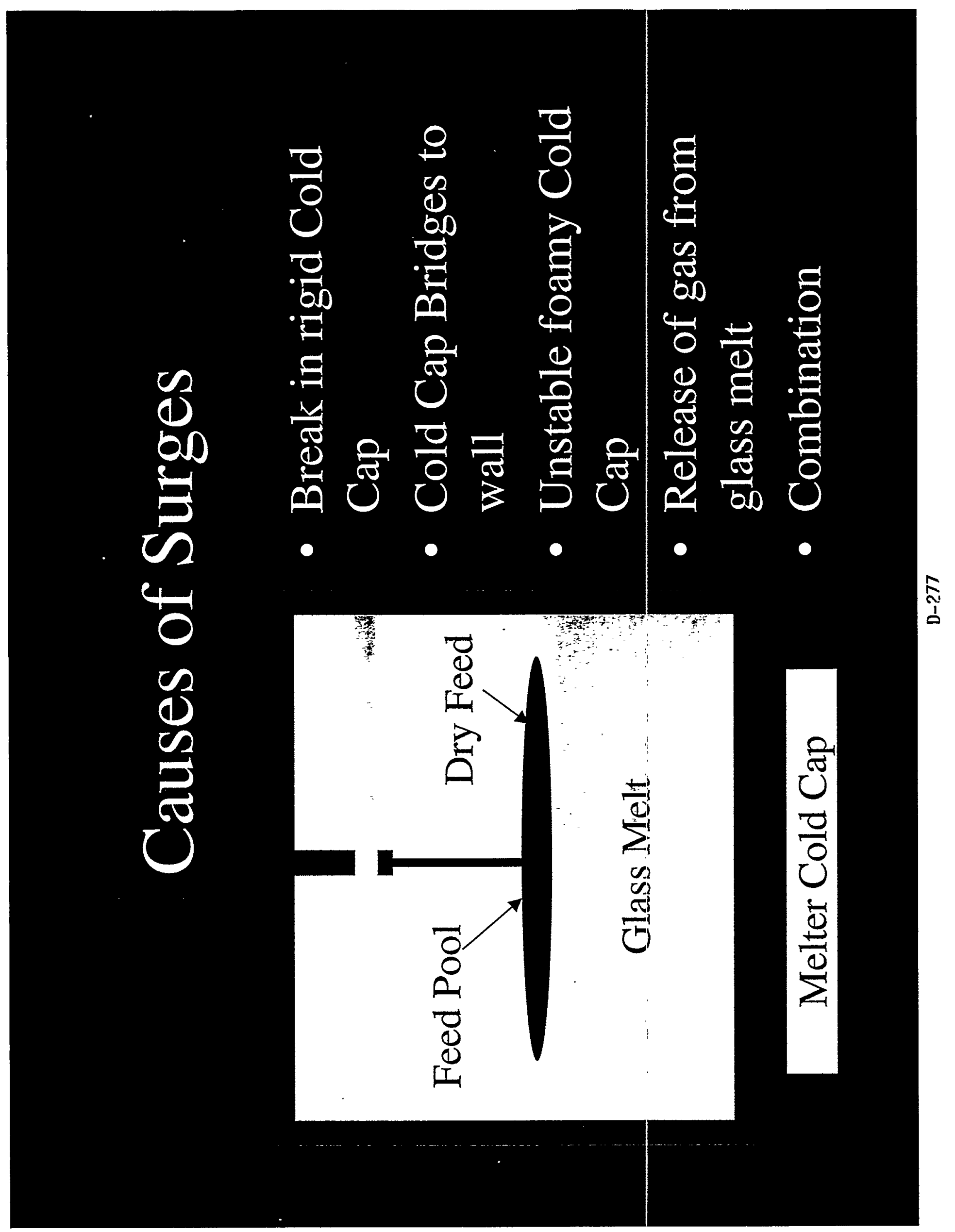



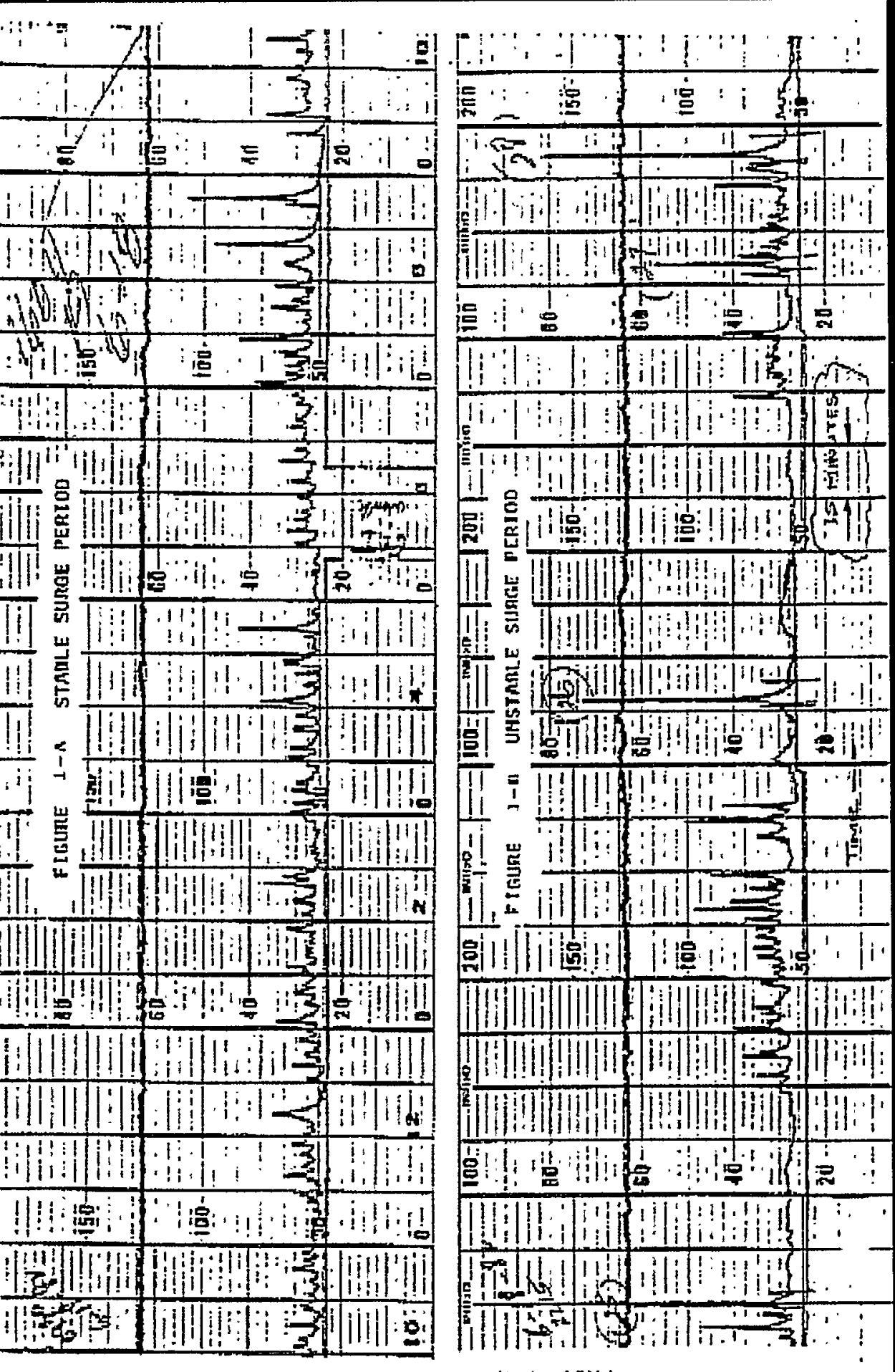

$\underset{\substack{\vdots \\ \vdots}}{\stackrel{\infty}{\vdots}}$ 

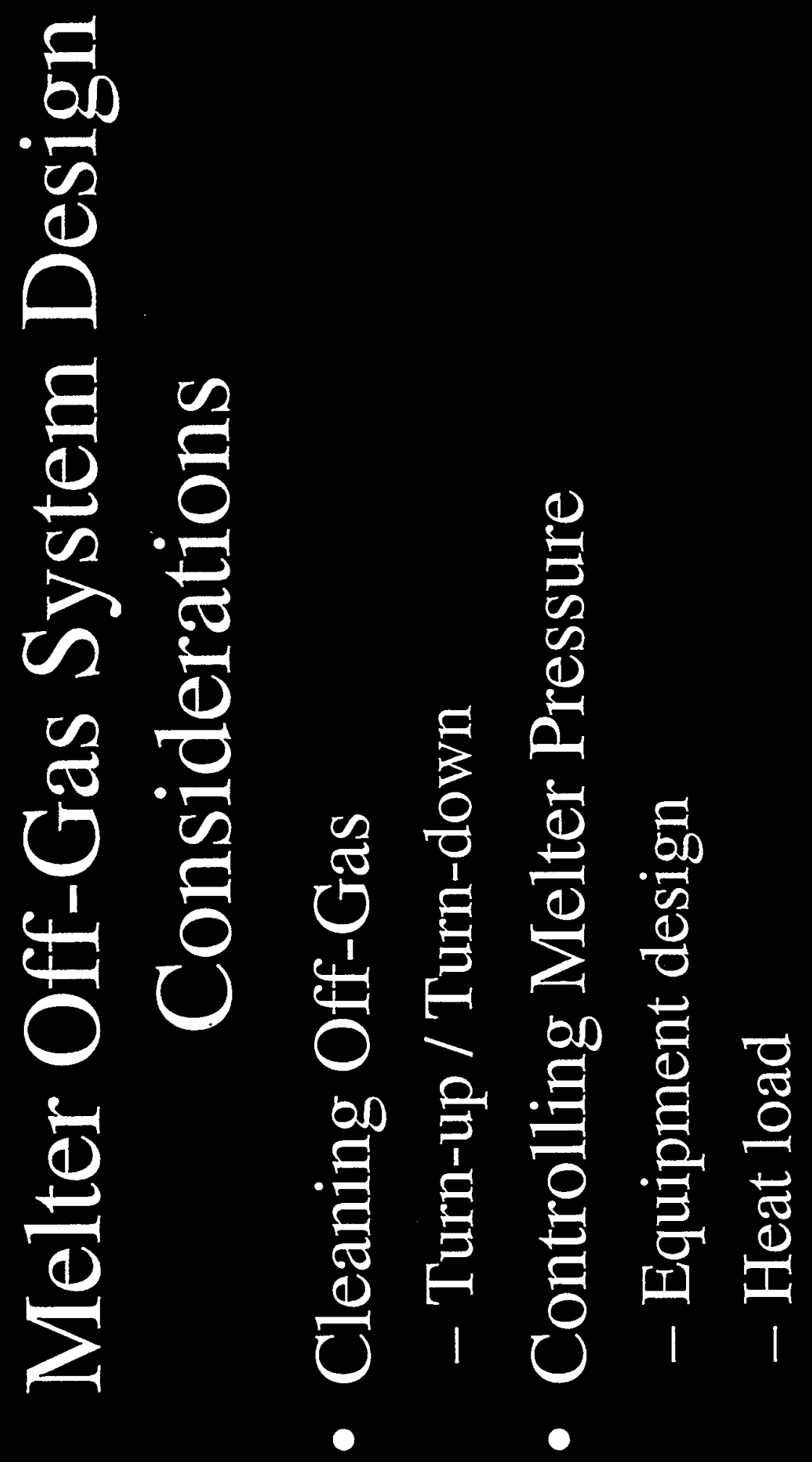

.

0
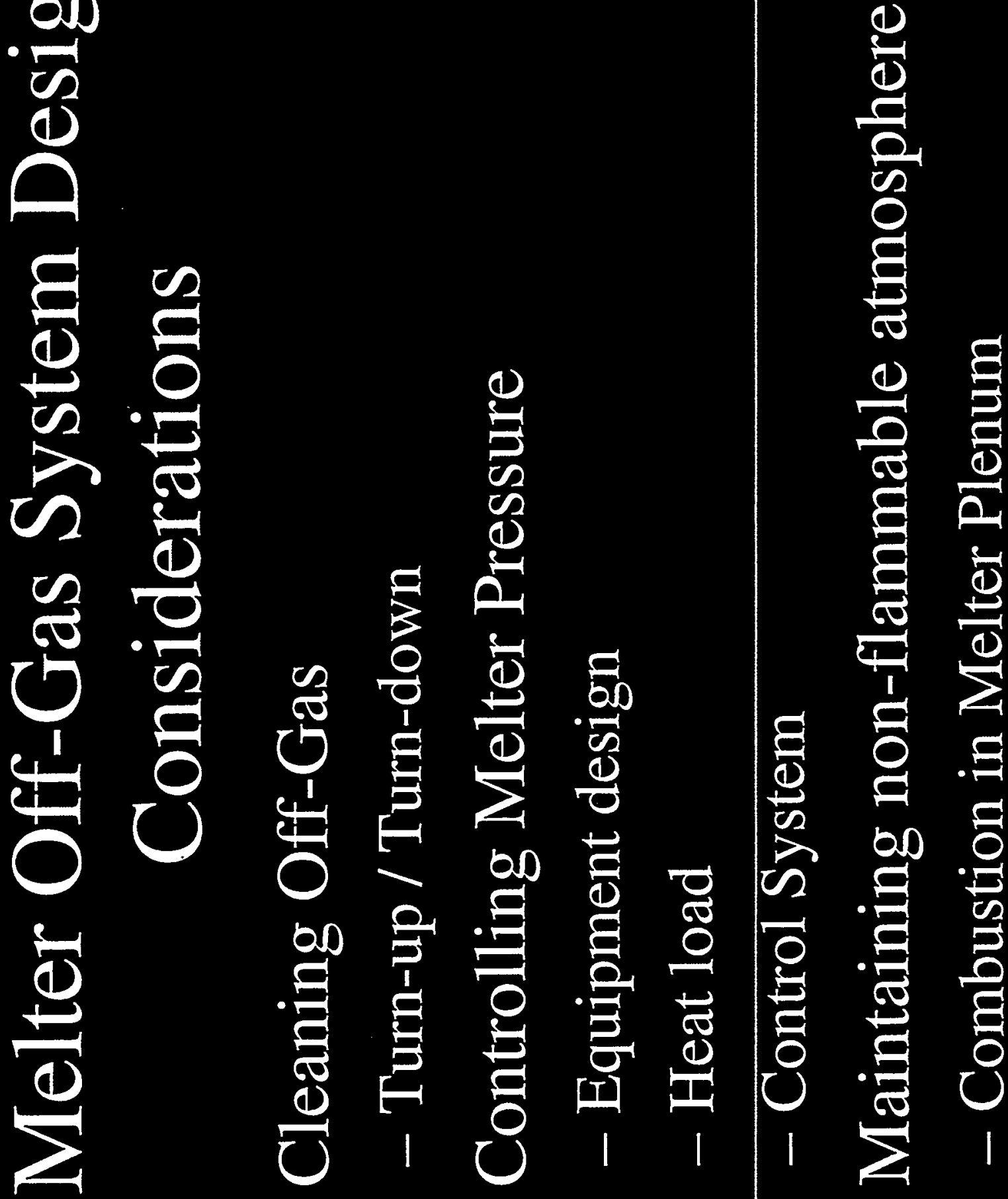


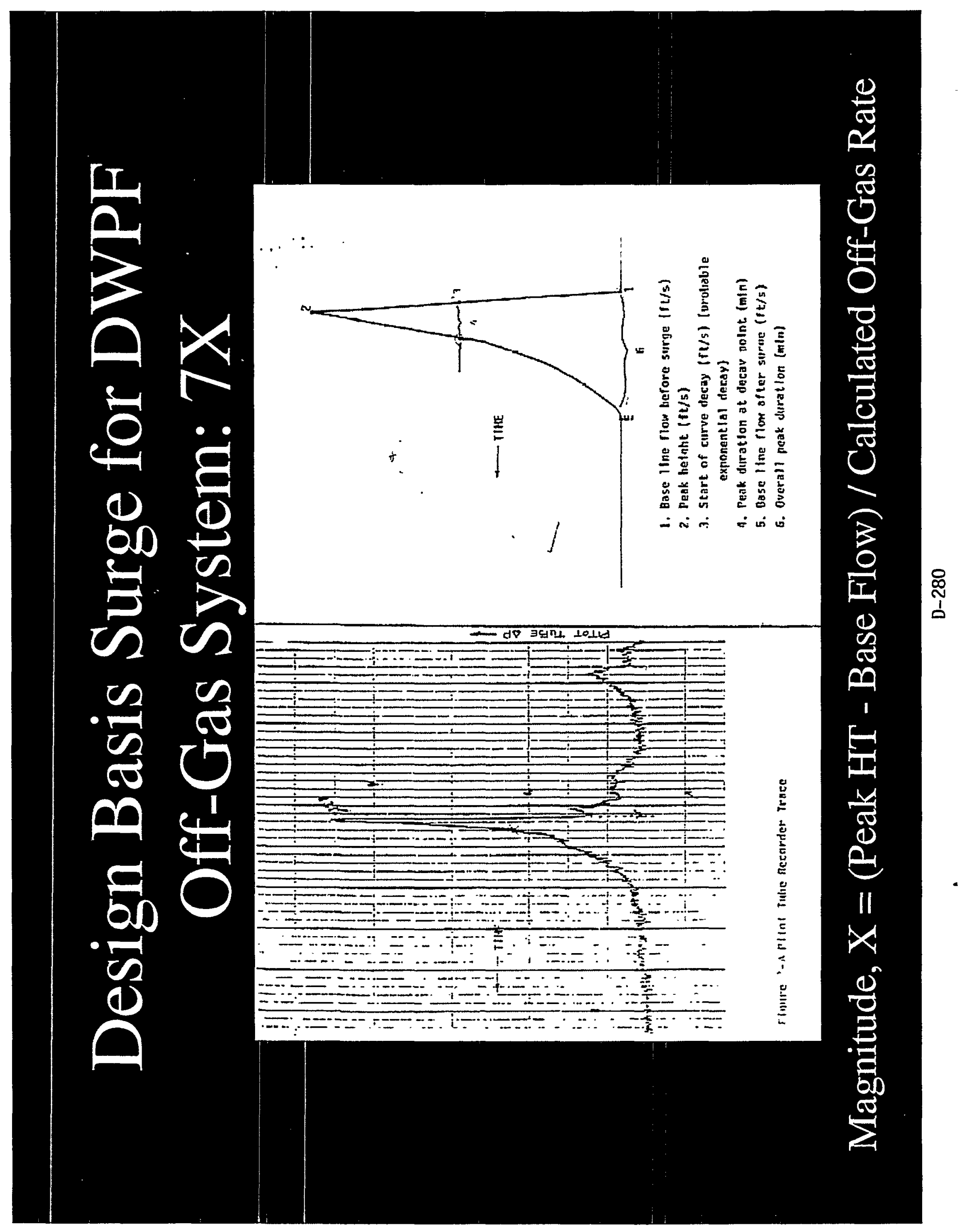



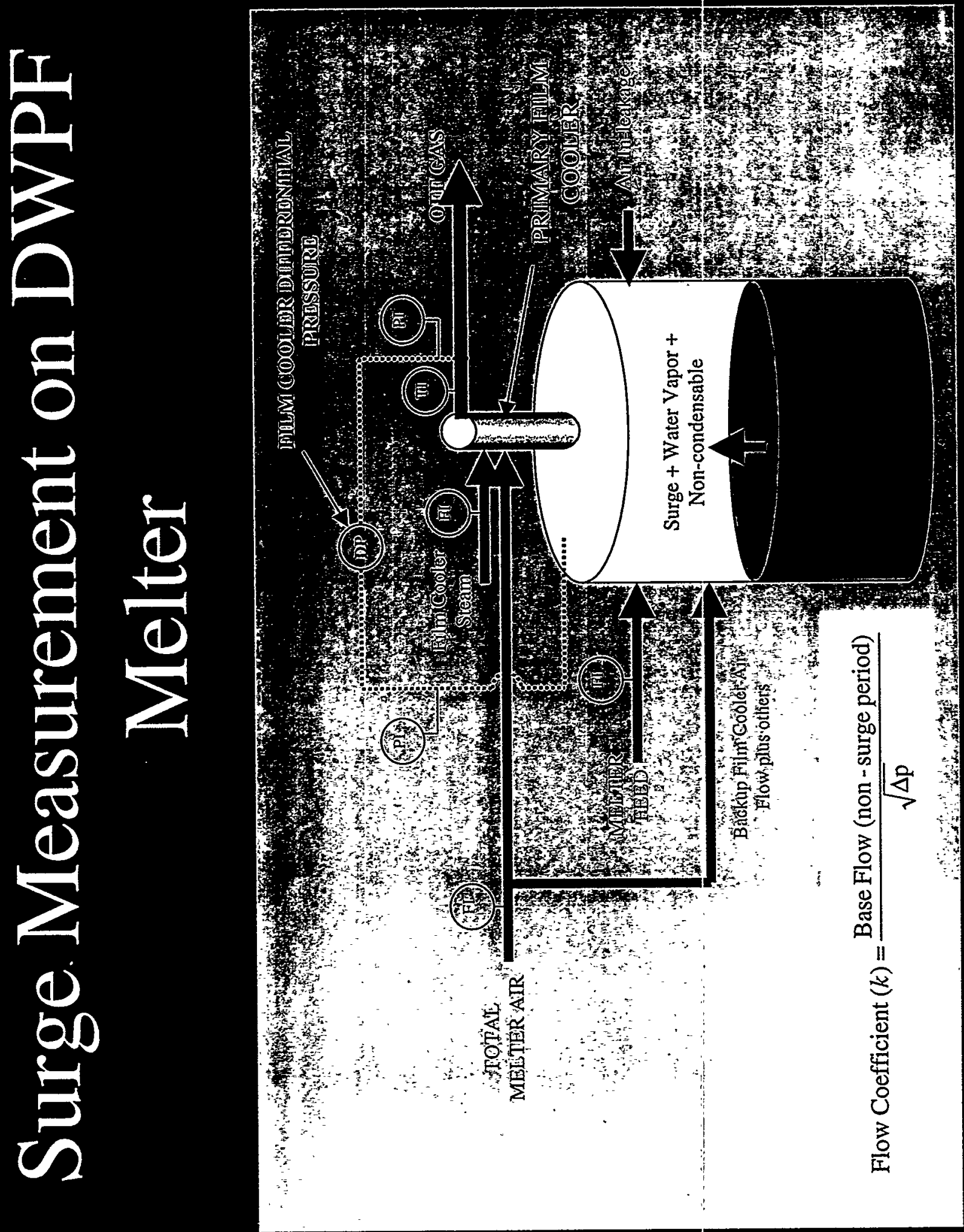

ণ্ৰ 


\section{DWPF Surge During Cold Runs: 9X}

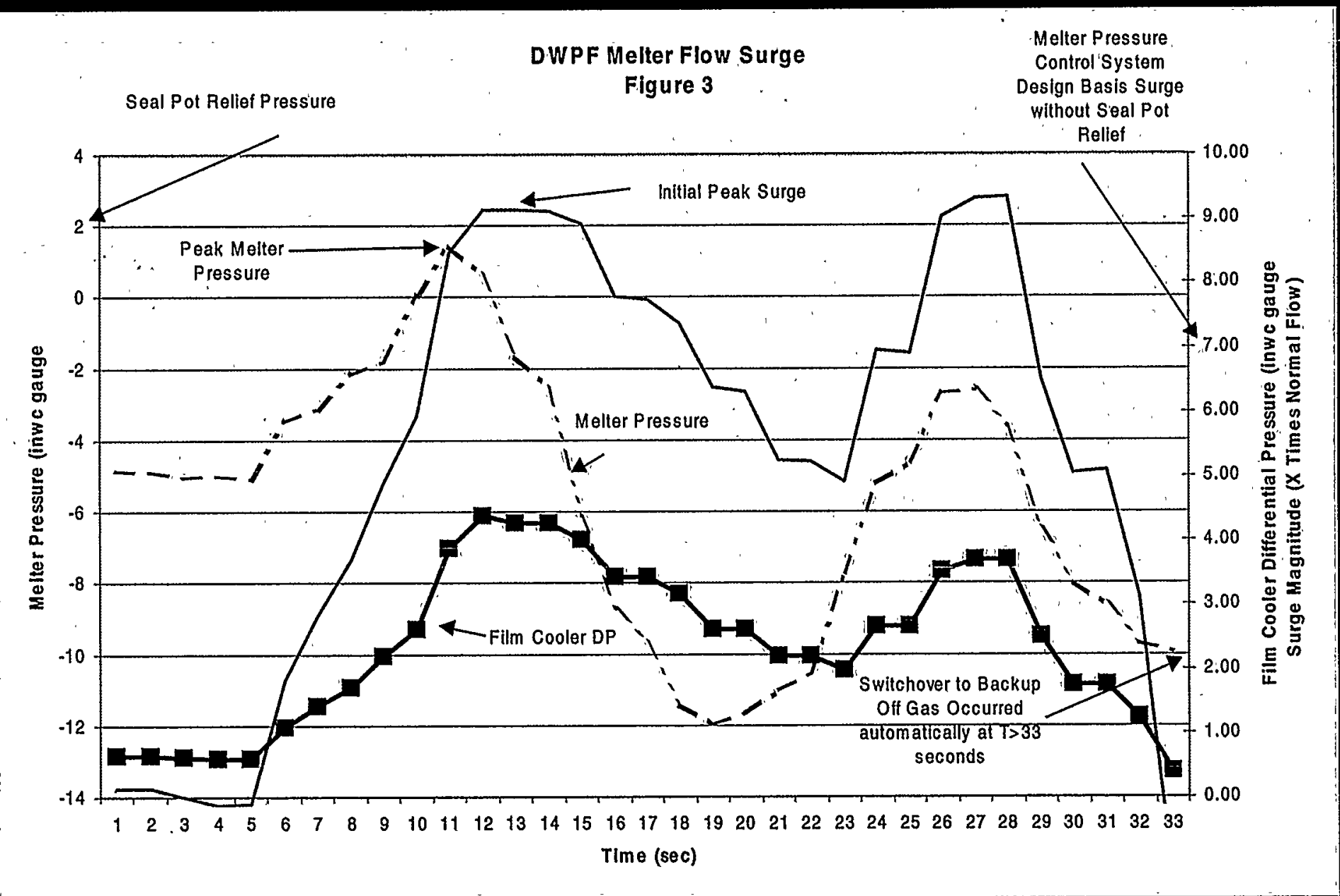




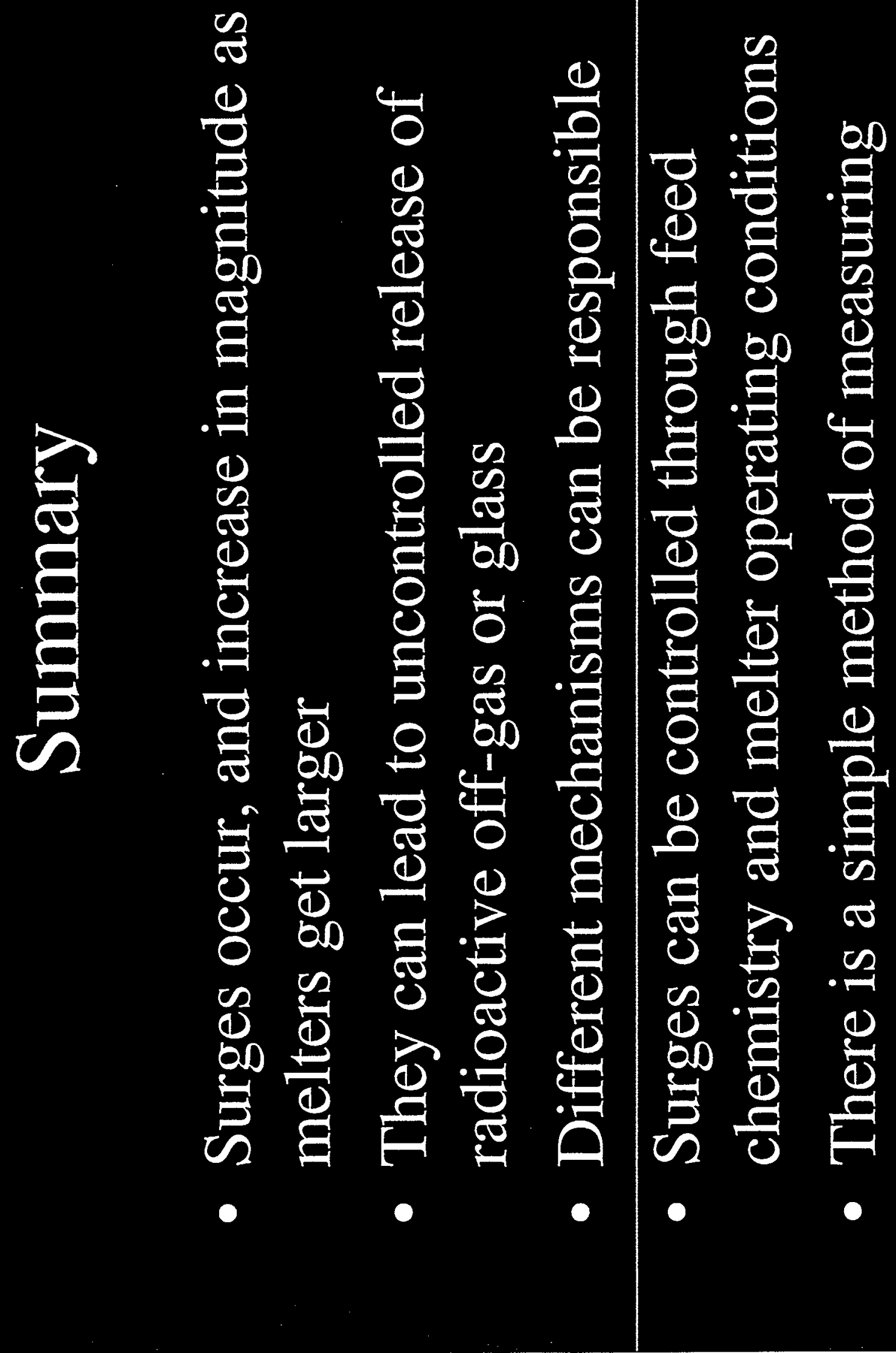




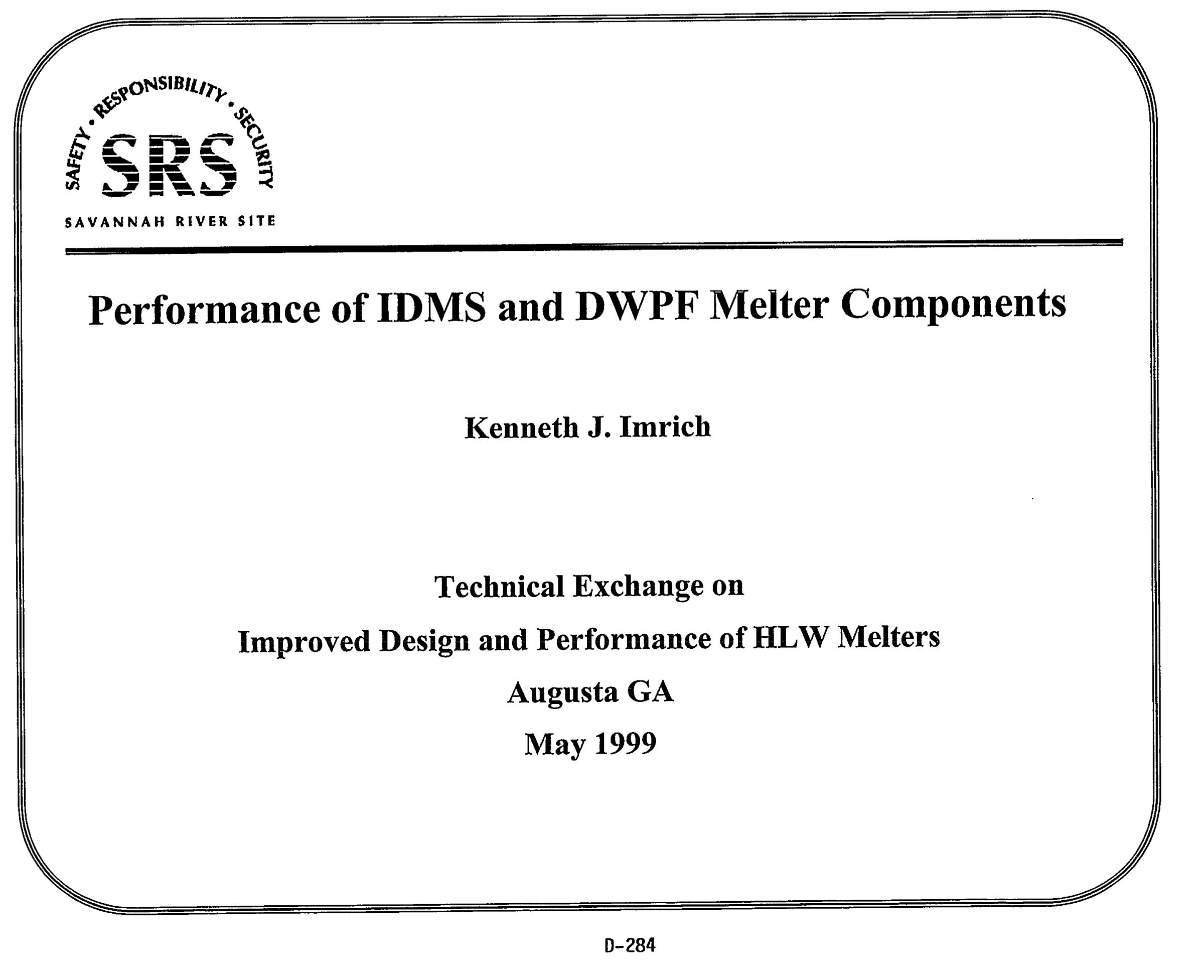




\section{Schematic of the DWPF \& IDMS Melters}

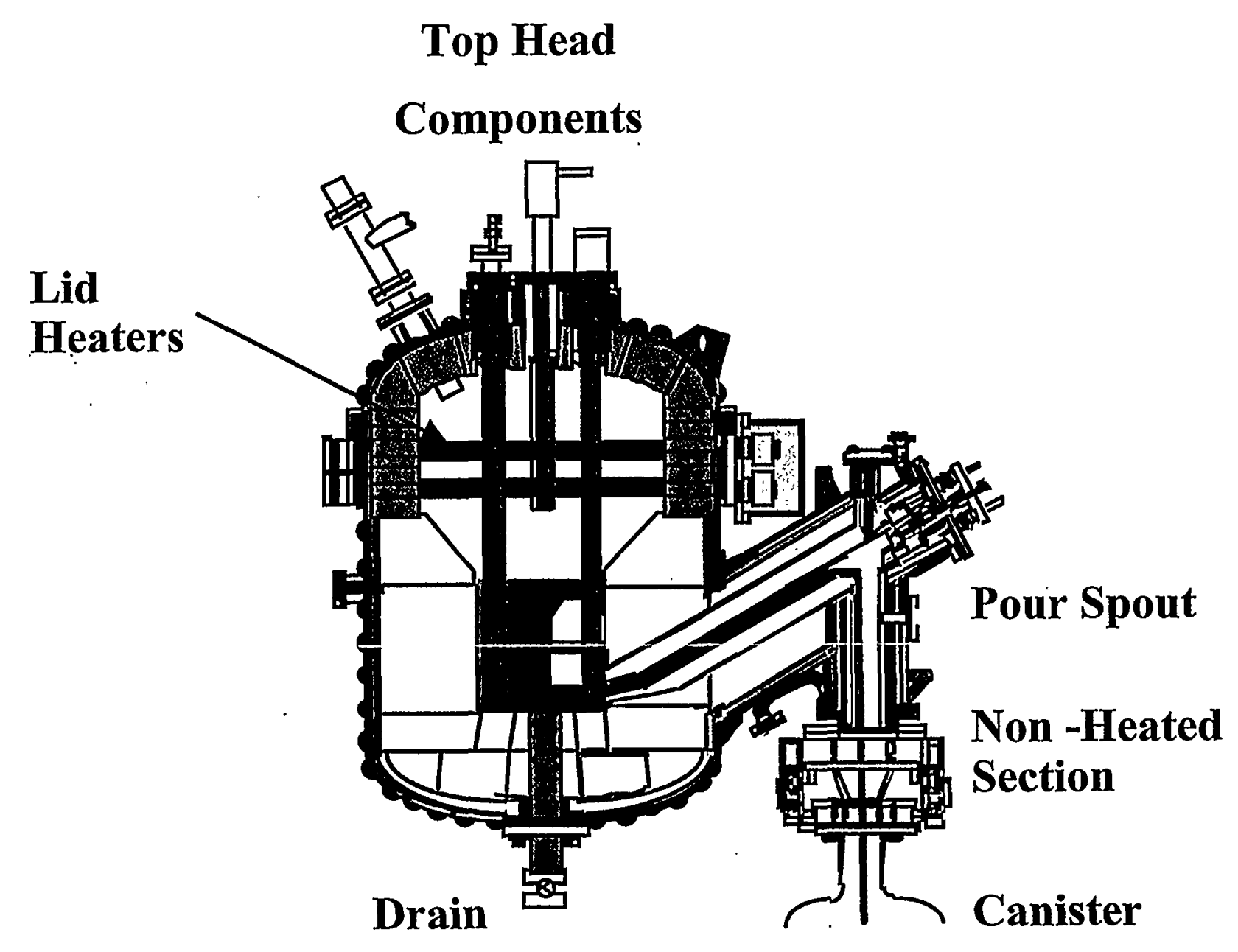




\section{Visual Examinations}

of

DWPF Melter Top Head and Off-Gas Components

\section{DWPF (10 months)}

- Top Head Components (1 690)

- Vapor space \& melt pool thermowells

- Backup film cooler $\&$ brush

- Level probe

- Borescopes (severe oxidation/corrosion)

- Primary film cooler \& brush (severe pitting)

- Feed tubes (end grain attack of core end piece)

- Pour spout (pitting)

- Off-Gas Components (I 690, Allcorr, \& C-276)

- Backup off-gas line

- Isolation valves

- Primary quencher

- Primary off-gas line (pitting) 


\title{
DWPF
}

\section{Top Head \& Off-Gas Components}

\author{
(Satisfactory Performance - 10 months)
}

- Vapor Space, Center \& Melt Pool Thermowells (I 690)

- Level Probe (1 690)

- Primary Quencher (Allcorr)

- Backup Film Cooler \& Brush (I 690)

- Melter Off Gas Line (I 690) 


\section{DWPF Vapor Space Thermowell}

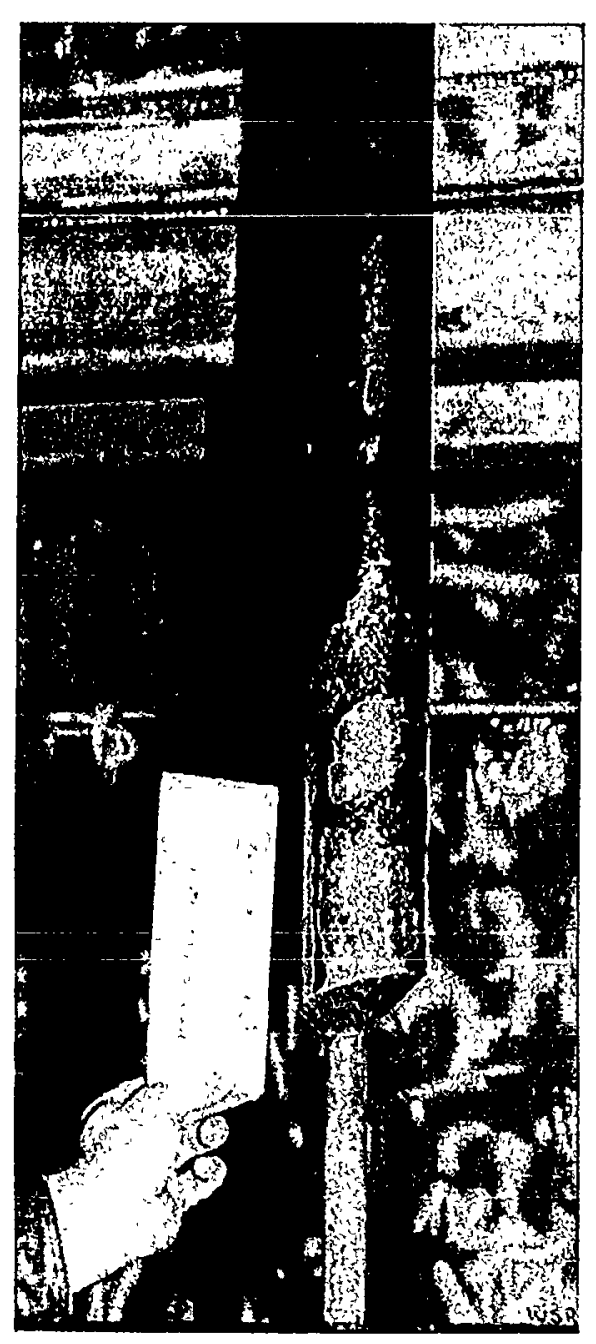




\section{DWPF}

\section{Melter Off-Gas Line}

- Component Background

- Inconel 690

- 10 months service

- Dilution of gas with air from film cooler

- High temperature (gas)

- Corrosive vapors / salt deposits

- Problem

- Severe pitting near inlet 


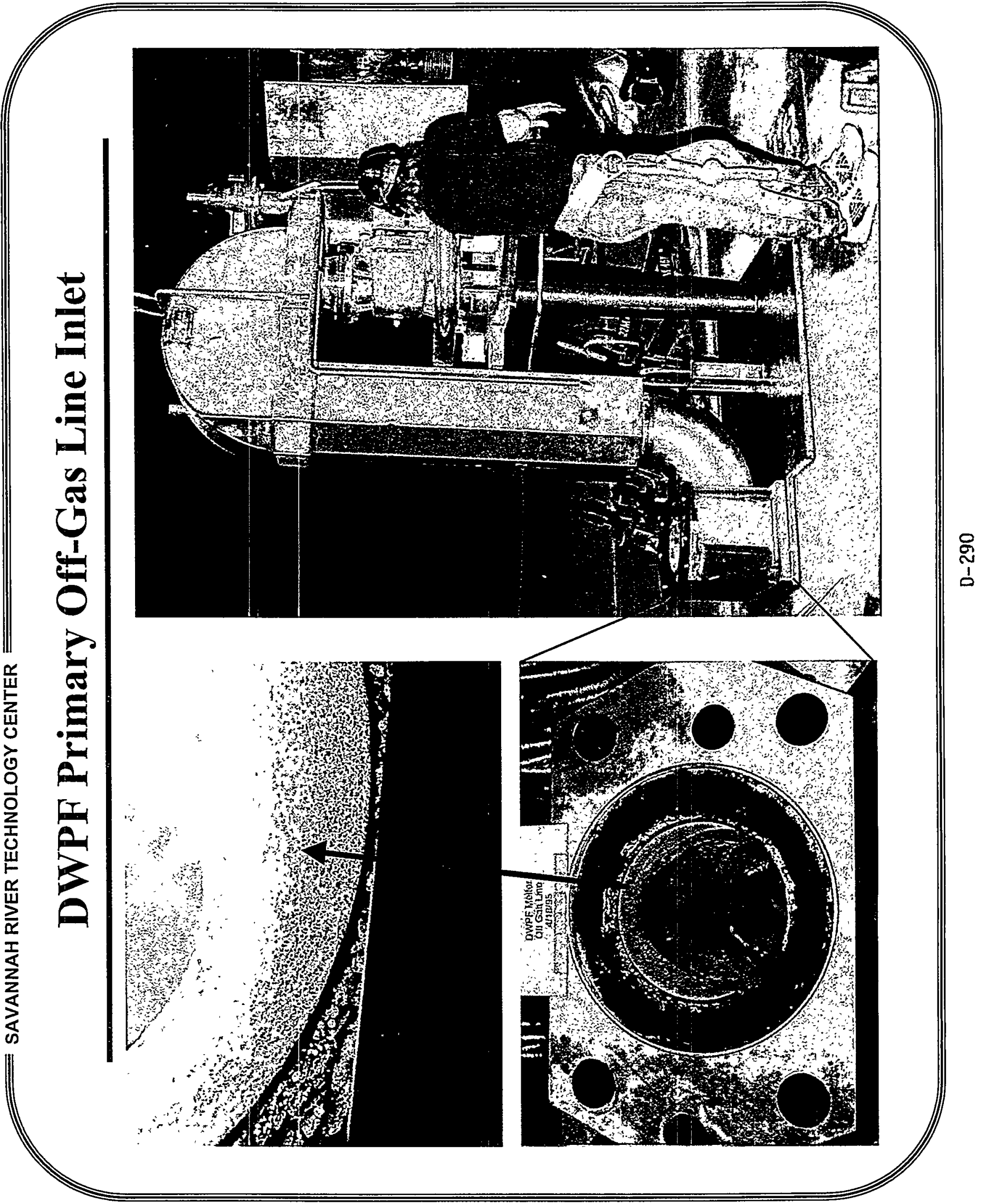




\section{DWPF}

\section{Film Cooler}

- Component Background

- Inconel 690

- 10 months service

- Air purge

- High temperature (gas and radiant heat from lid heaters and molten glass)

- Corrosive vapors and salt deposits

- Problem

- Oxidation / corrosion

- Proposed Solution

- Alternate material - coating or Inconel 690M 


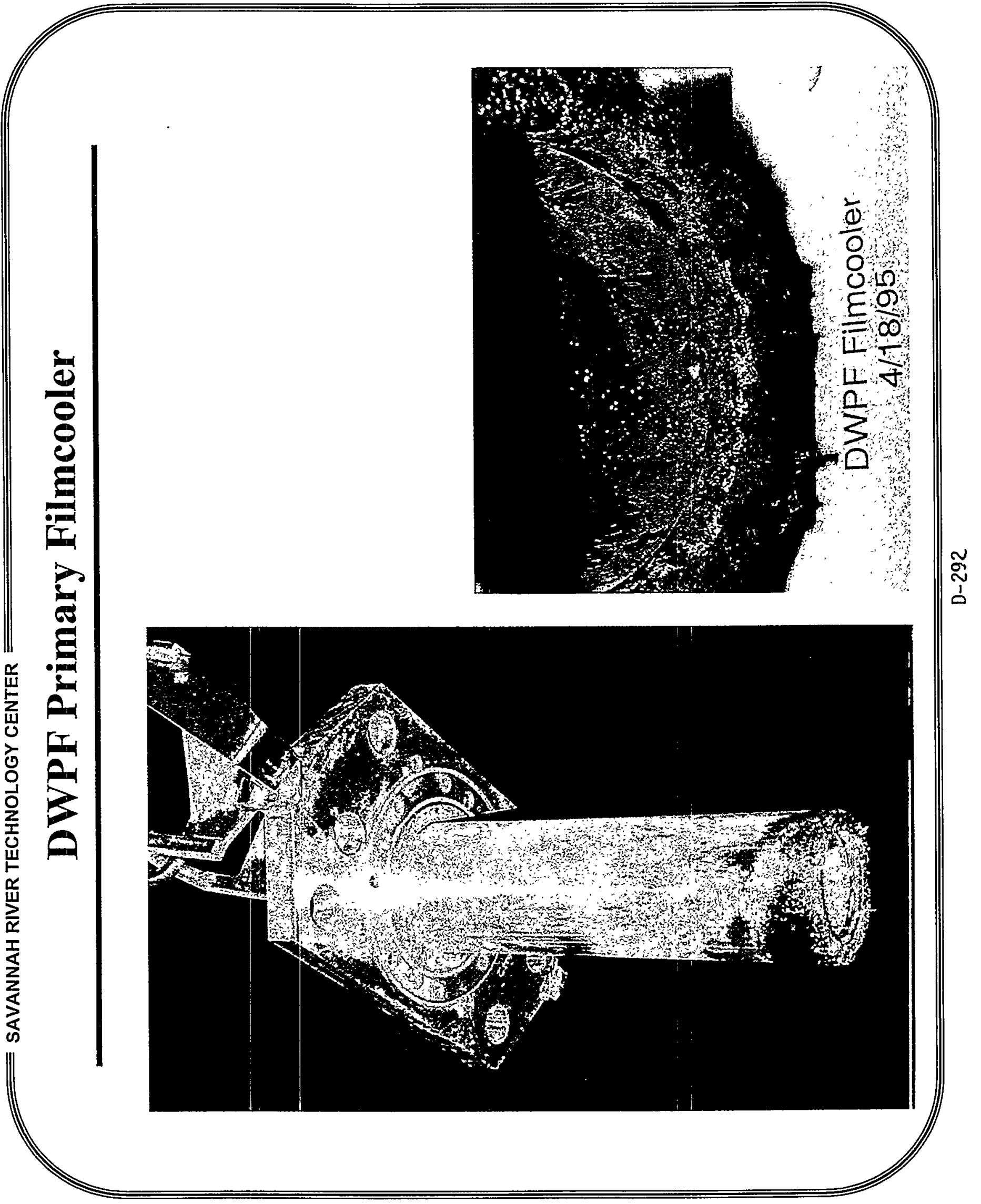




\section{DWPF}

\section{Filmcooler Brush}

- Component Background

- Inconel 690

- 10 months service

- Dilution of gas with air from film cooler

- High temperature (gas)

- Corrosive vapors / salt deposits

- Problem

- Component was fabricated from Hastelloy X

- Oxidation of molybdenum

- Corrosion resulting from salt deposits

- Proposed Solution

- Install only when required

- Fabricate from Inconel 690 


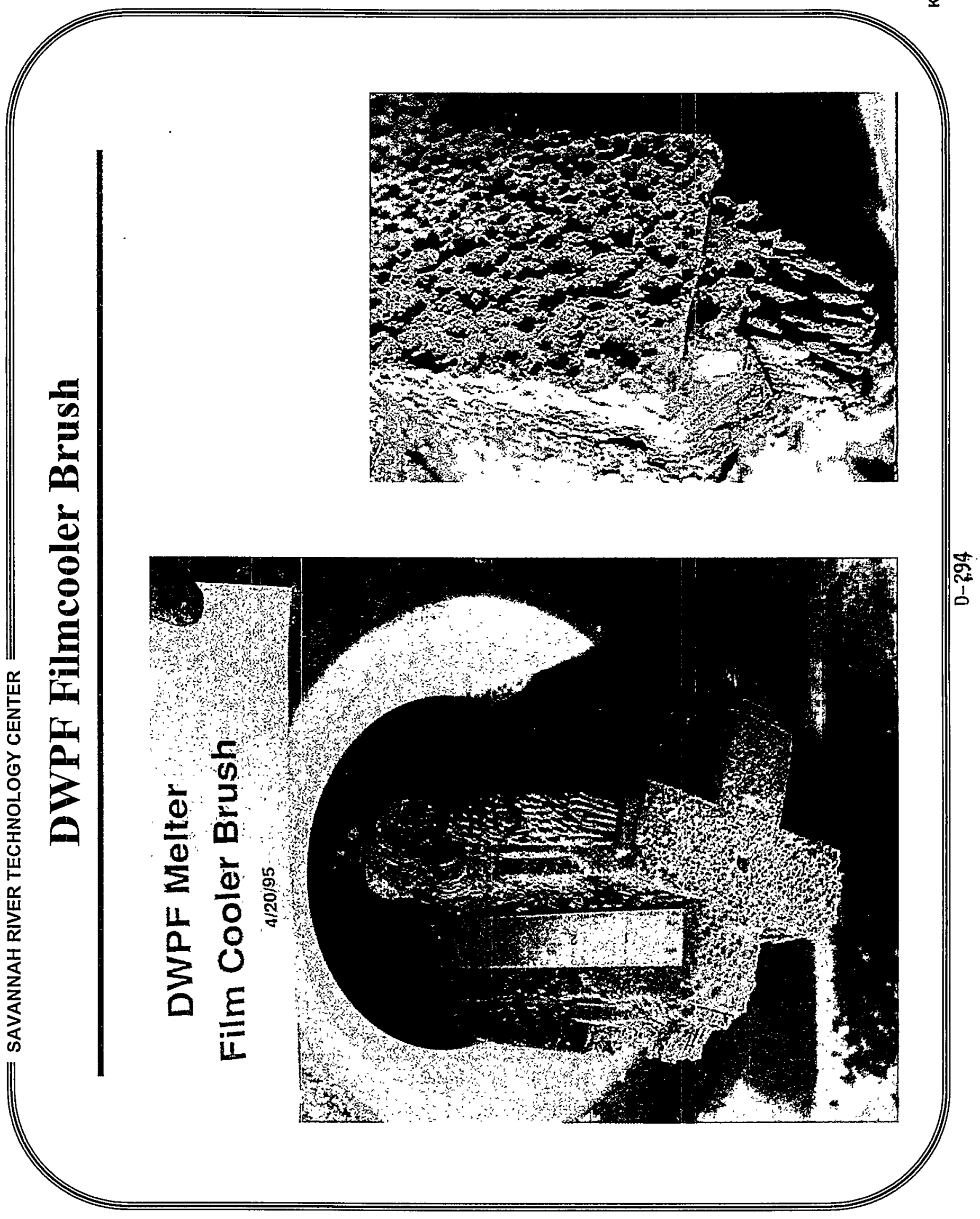




\section{DWPF \\ Borescope Outer Housing}

- Component Background

- Inconel 690

- 3 months service

- Air purge (continuous)

- Steam purge (hourly)

- High temperature (radiant heat from lid heaters and molten glass)

- Corrosive vapors / salt deposits

- Chloride concentration $>5000$ ppm

- Sulfate concentration > 10000 ppm

- Problem

- Oxidation around orifice(signifícant Cr depietion)

- Severe pitting on outer housing break-away corrosion (> $360 \mathrm{mpy}$ )

- Proposed Solution

- Cr/Al diffusion coating

- Alternate material - Inconel 690M 


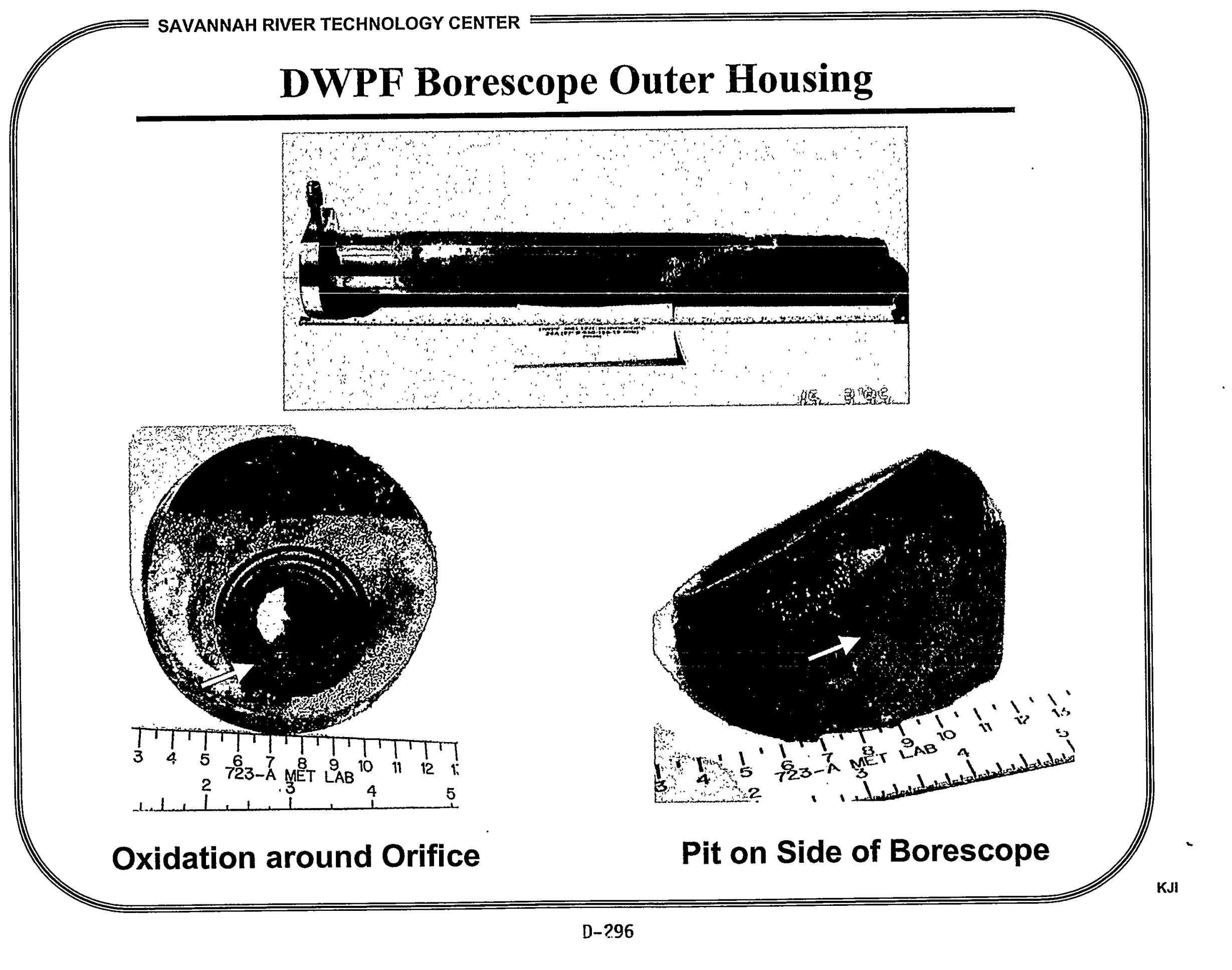




\section{DWPF \\ Feed Tube}

- Component Background

- Inconel 690

- 10 months service

- Water cooled

- High temperature (radiant heating from molten glass)

- Corrosive vapors

- Problem

- End grain attack of core end piece

- Proposed Solution

- Remove degraded material

- Weld overlay tip to cover exposed end grains

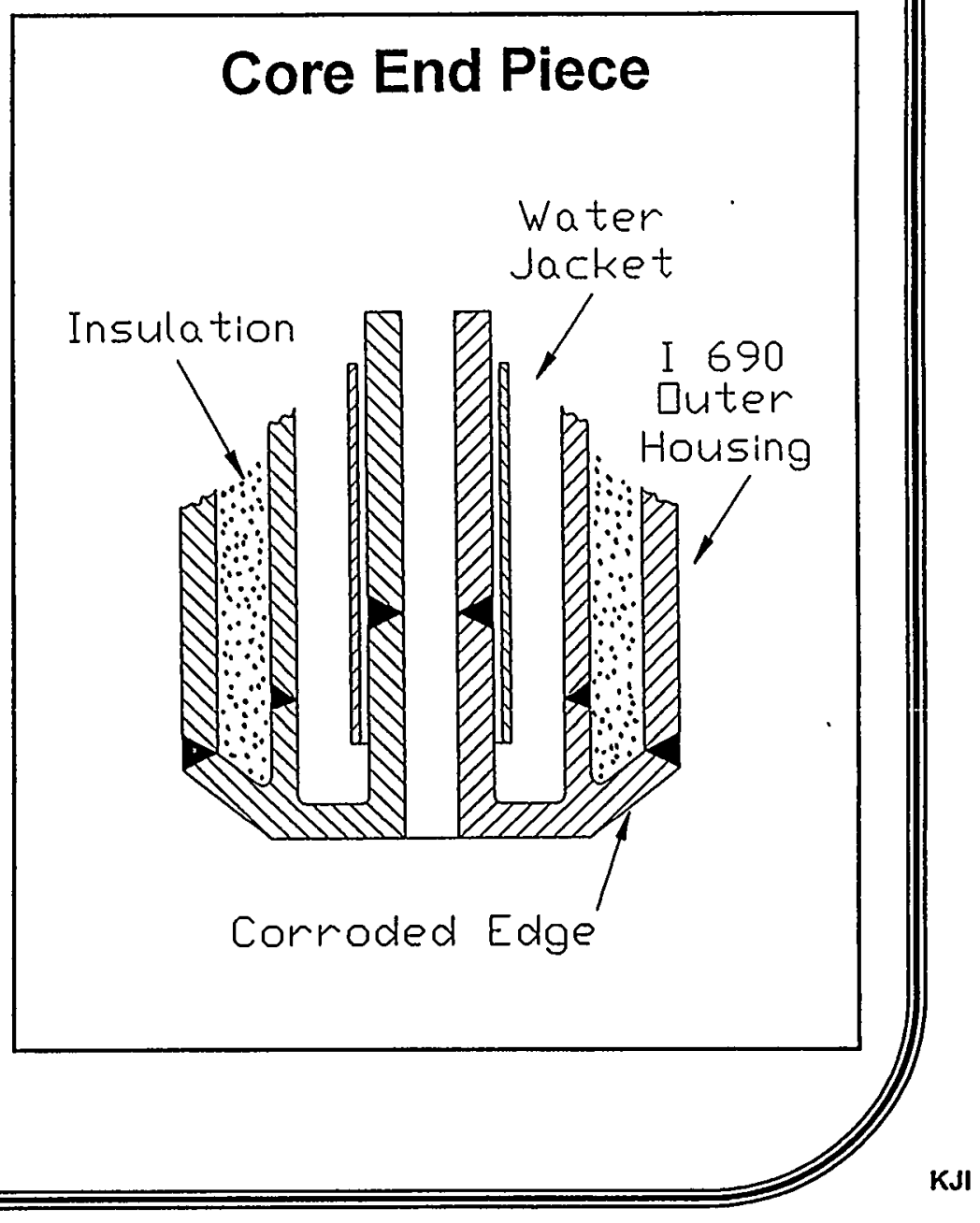




\section{DWPF Feed Tube}

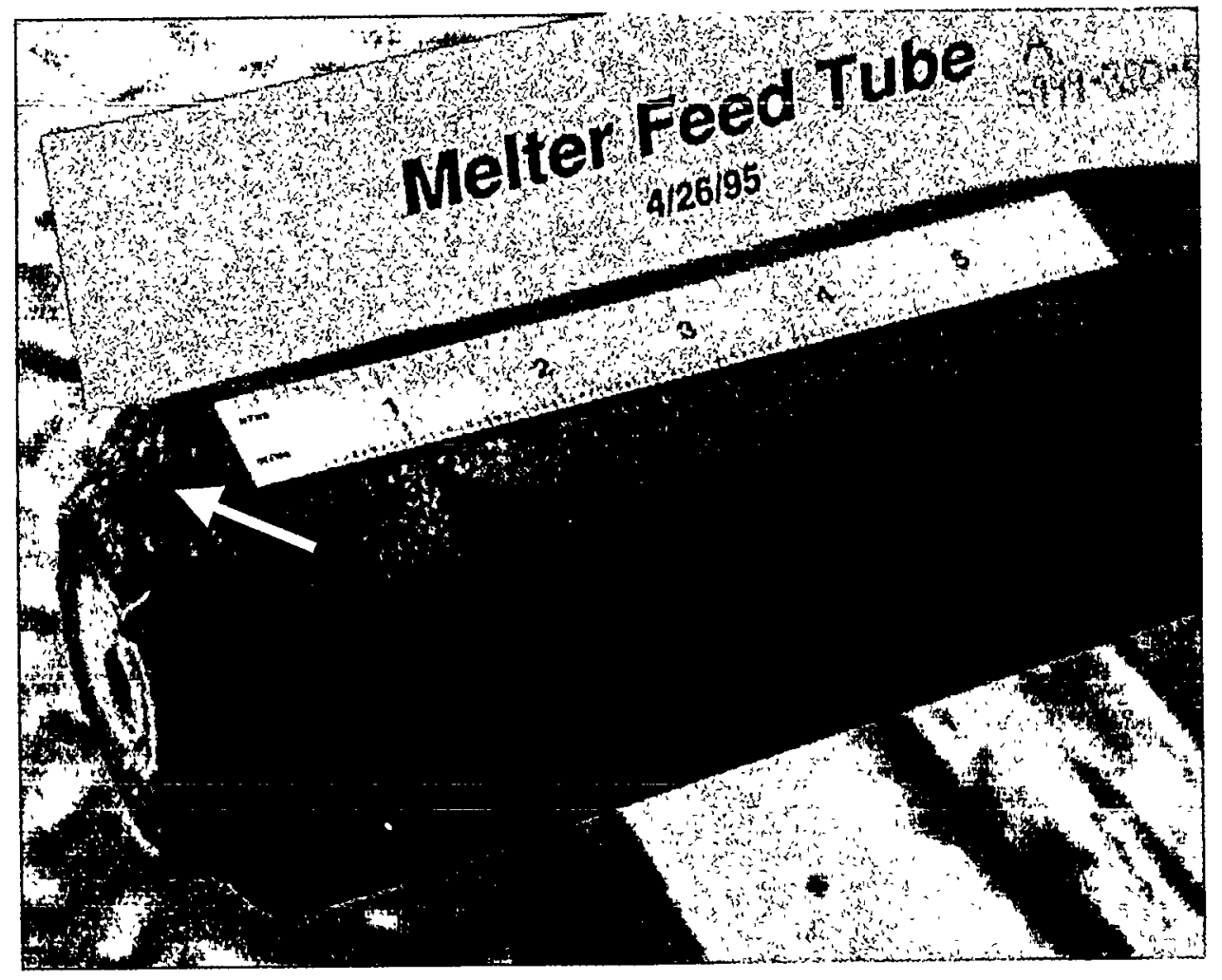




\section{DWPF Pour Spout}

\section{Non-Heated Section Above Bellows}

- Component Background

- Inconel 690

- 1 year non-radioactive service

- High temperature $\left(500{ }^{\circ} \mathrm{C}\right)$

- Corrosive vapors / salt deposits

- Problem

- Severe pitting (penetrated wall 0.20")

- Break-away corrosion (sodium chloride)

- No significant chromium depletion in pitted region 


\section{DWPF Non-Heated Section Above Bellows}
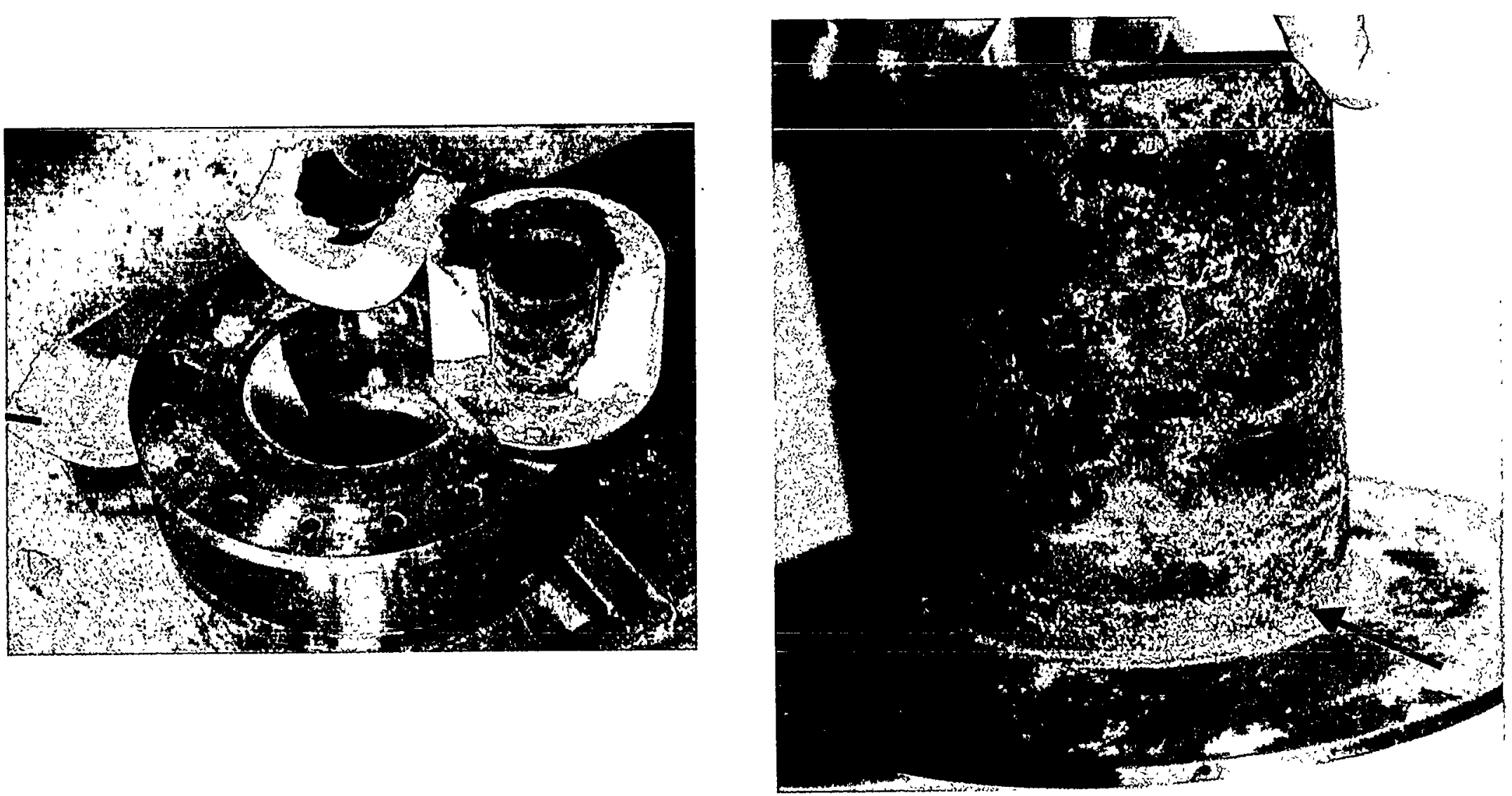


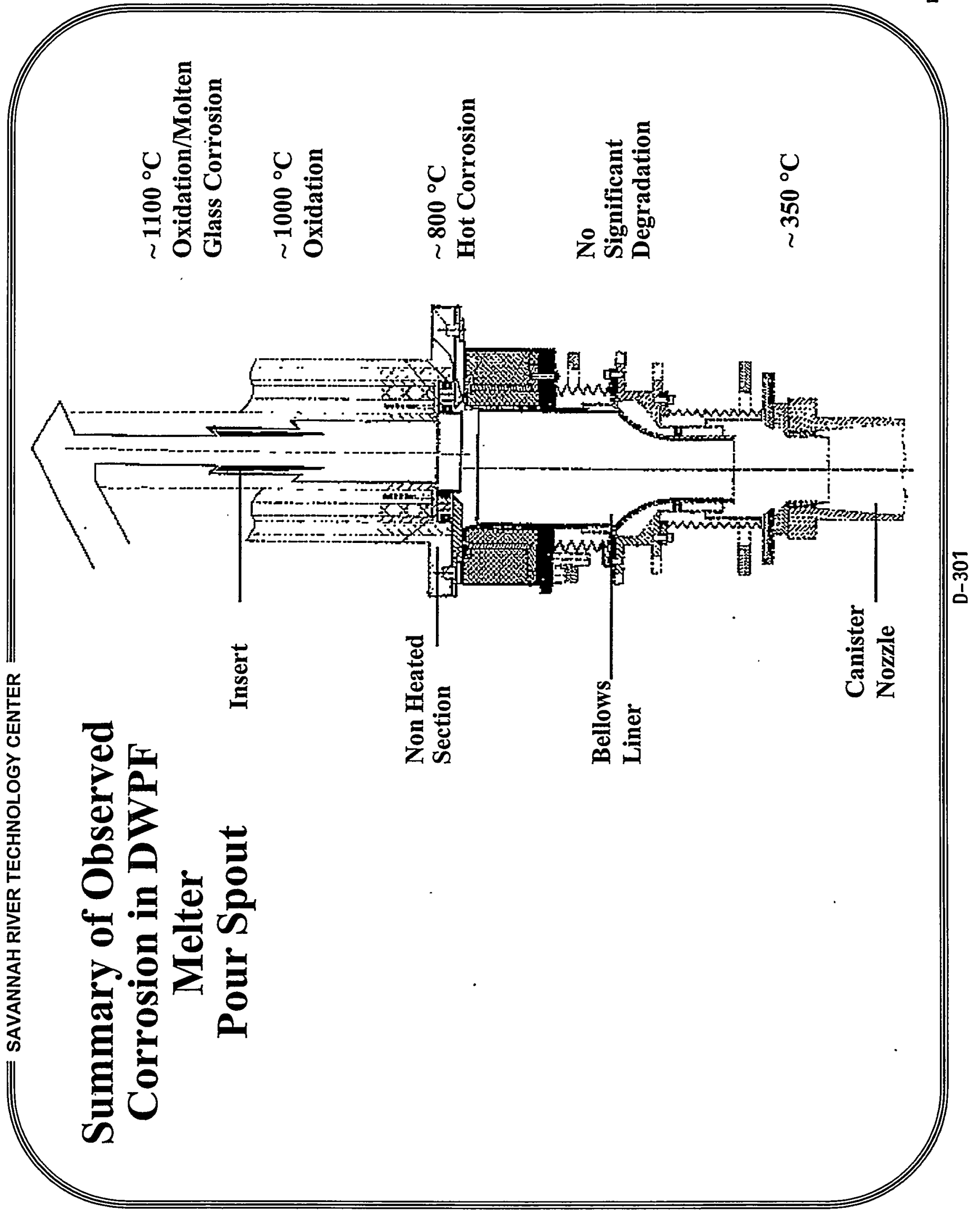




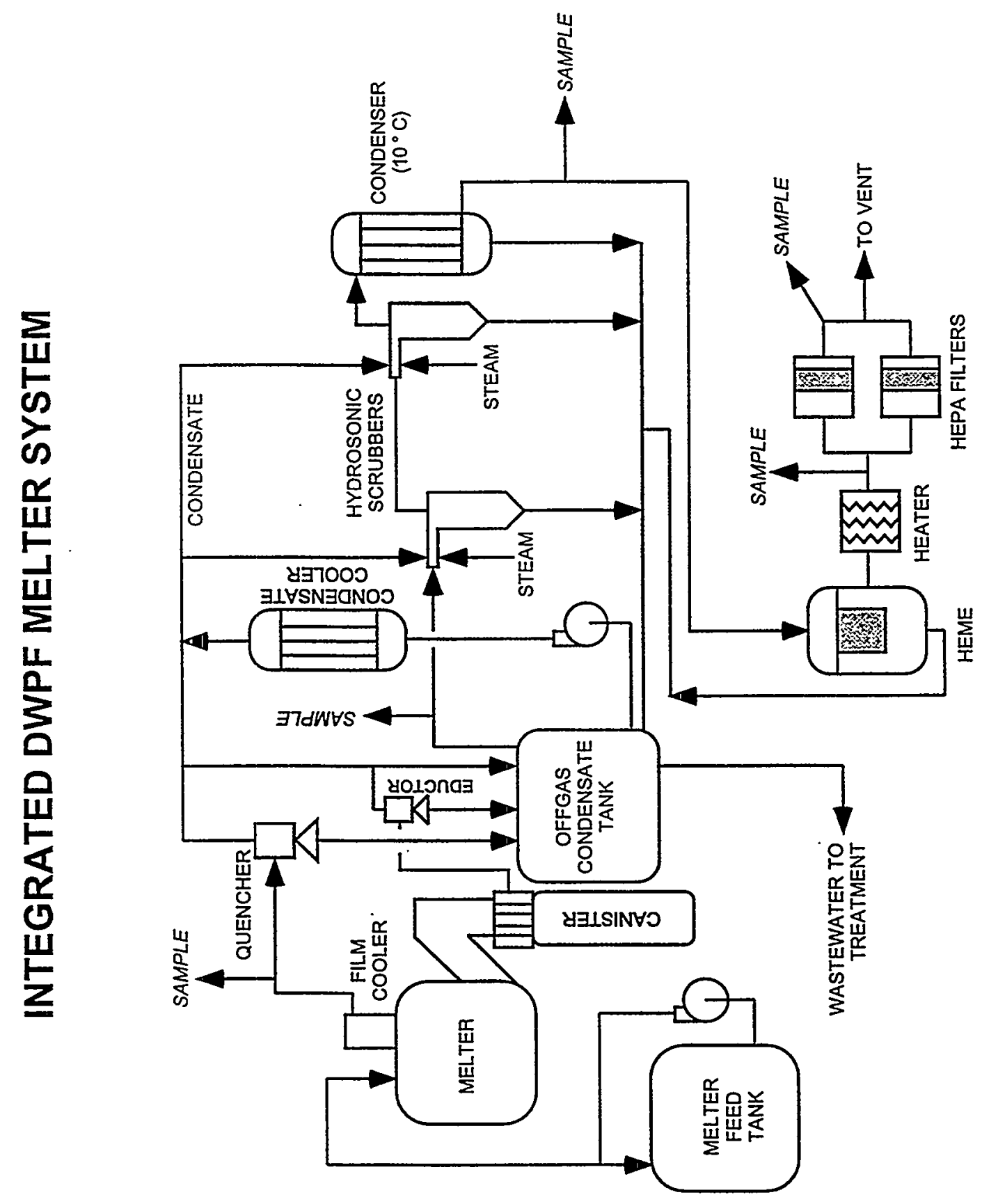

ঠ̃ 


\section{DESIGN AND MEASURED CESIUM DECONTAMINATION FACTORS}

\begin{tabular}{|c|c|c|c|c|c|}
\hline F across: & $\begin{array}{c}\text { IDMS Cesium Flow } \\
\text { Rate }(\mathrm{g} / \mathrm{h})\end{array}$ & $\begin{array}{c}\text { IDMS } \\
\text { Measured } \\
\text { DF }\end{array}$ & $\begin{array}{l}\text { Scaled DWPF } \\
\text { Cesium } \\
\text { Flow Rate }(g / h)\end{array}$ & $\begin{array}{c}\text { Original } \\
\text { DWPF } \\
\text { Design DF }\end{array}$ & $\begin{array}{l}\text { Modified } \\
\text { DWPF } \\
\text { Design DF }\end{array}$ \\
\hline $\begin{array}{r}\text { Melter Feed } \\
\text { Melter Offgas } \\
\text { Quencher/OGCT } \\
\text { SAS/Condenser } \\
\text { HEME } \\
\text { HEPA \#1 } \\
\text { HEPA \#2 } \\
\text { Overall (without HEPAs) } \\
\text { Overall (without HEPAs \& } \\
\text { Melter) }\end{array}$ & $\begin{array}{c}20.1 \\
0.1524 \pm 0.0834 \\
0.0576 \pm 0.0336 \\
2.02 \pm 1.25 \times 10^{-3} \\
6.42 \pm 4.68 \times 10^{-6} \\
0.858 \pm 1.146 \times 10^{-6} \\
\text { NA }\end{array}$ & $\begin{array}{c}- \\
132 . \\
2.7 \\
28.5 \\
314 . \\
0.75 \\
\text { NA } \\
31.3 \times 10^{5} \\
2.37 \times 10^{4}\end{array}$ & $\begin{array}{c}10.1 \\
0.0911 \\
0.00911 \\
1.82 \times 10^{-4} \\
4.56 \times 10^{-6} \\
9.11 \times 10^{-9} \\
1.82 \times 10^{-10}\end{array}$ & $\begin{array}{c}- \\
15 . \\
8.9 \\
50 . \\
40 . \\
422 . \\
24.5 \\
2.67 \times 10^{5} \\
1.78 \times 10^{4}\end{array}$ & $\begin{array}{c}- \\
111 . \\
10 . \\
50 . \\
40 . \\
500 . \\
50 . \\
22.2 \times 10^{5} \\
2.00 \times 10^{4}\end{array}$ \\
\hline
\end{tabular}


DESIGN AND MEASURED TOTAL PARTICULATE DECONTAMINATION FACTORS

\begin{tabular}{|rcc|} 
DF across: & DWPF Design ${ }^{*}$ DF & IDMS Measured DF \\
\hline Melter & 69 & 2626. \\
Quencher/OGCT & $<10$ & 2.85 \\
SAS/Condenser & 50 & 20.6 \\
HEME & 40 & 8.2 \\
HEPA \#1 & $<500$ & 1.43 \\
HEPA \#2 & $<50$ & NA \\
Overall (without HEPAs) & $\sim 1.38 \times 10^{6}$ & $1.24 \times 10^{6}$ \\
\hline
\end{tabular}

* Design DF values indicated are for entrainment only; semi-volatile values will be smaller. 


\section{DWPF DESIGN AND IDMS MEASURED MERCURY CONCENTRATIONS AND DECONTAMINATION FACTORS}

\begin{tabular}{|c|c|c|c|c|c|c|c|c|}
\hline \multirow[b]{2}{*}{ DF across: } & \multicolumn{2}{|c|}{ Concentration ${ }^{1}$} & \multicolumn{2}{|c|}{ Flow Rate $(\mathrm{g} / \mathrm{h})$} & \multirow{2}{*}{$\begin{array}{l}\text { Scale }^{2} \\
\text { DWPF } \\
\text { Design }\end{array}$} & \multicolumn{2}{|c|}{ IDMS DF } & \multirow{2}{*}{$\begin{array}{c}\text { DWPF } \\
\text { Design } \\
\text { DF }\end{array}$} \\
\hline & Run 1 & Run 2 & Run 1 & Run 2 & & Run 1 & Run 2 & \\
\hline Melter Feed & 6.3 & 37.0 & 0.164 & 0.961 & 17.16 & & & \\
\hline OGCT Liquid & $1.9^{3}$ & $11.9^{3}$ & & & 16.67 & & & \\
\hline Melter Offgas & 205. & 1185. & 0.158 & 0.979 & 17.16 & 1.04 & 0.98 & 1.00 \\
\hline Quencher/OGCT & 19. & 249. & 0.0225 & 0.295 & 12.13 & 7.00 & 3.32 & 1.41 \\
\hline SAS/Condenser & 3.6 & 154. & 0.00464 & 0.184 & 0.548 & 4.85 & 1.60 & 22.1 \\
\hline HEME & 1.9 & 34. & 0.00213 & 0.033 & 0.479 & 2.18 & 5.58 & 1.14 \\
\hline HEPA & & & NA & NA & 0.466 & NA & NA & 1.03 \\
\hline Overall w/o HEPA & & & & & & 77.0 & 29.0 & 35.5 \\
\hline Overall & & & & & & & & 36.59 \\
\hline
\end{tabular}




\section{Visual Examinations \\ of \\ IDMS Melter Top Head and Off-Gas Components}

\section{IDMS (7 years)}

- Top Head Components (1 690)

- Lid heaters

- Vapor space thermowell

- Level probe

- Borescope

- Melt pool thermowell (melt line corrosion)

- Film cooler (severe oxidation/corrosion)

- Feed tube (IGA just below melter lid)

- Vent line (severe oxidation/corrosion)

- Off-Gas Components (I 690 \& C-276)

- Off-gas line

- Vent line to seal pot

- Quencher 


\section{IDMS}

\section{Melt Pool Thermowell}

- Component Background

- Inconel 690

- 7 years service

- High temperature (molten glass and gas)

- Corrosive vapors

- Problem

- Severe corrosion / erosion at glass - air interface 


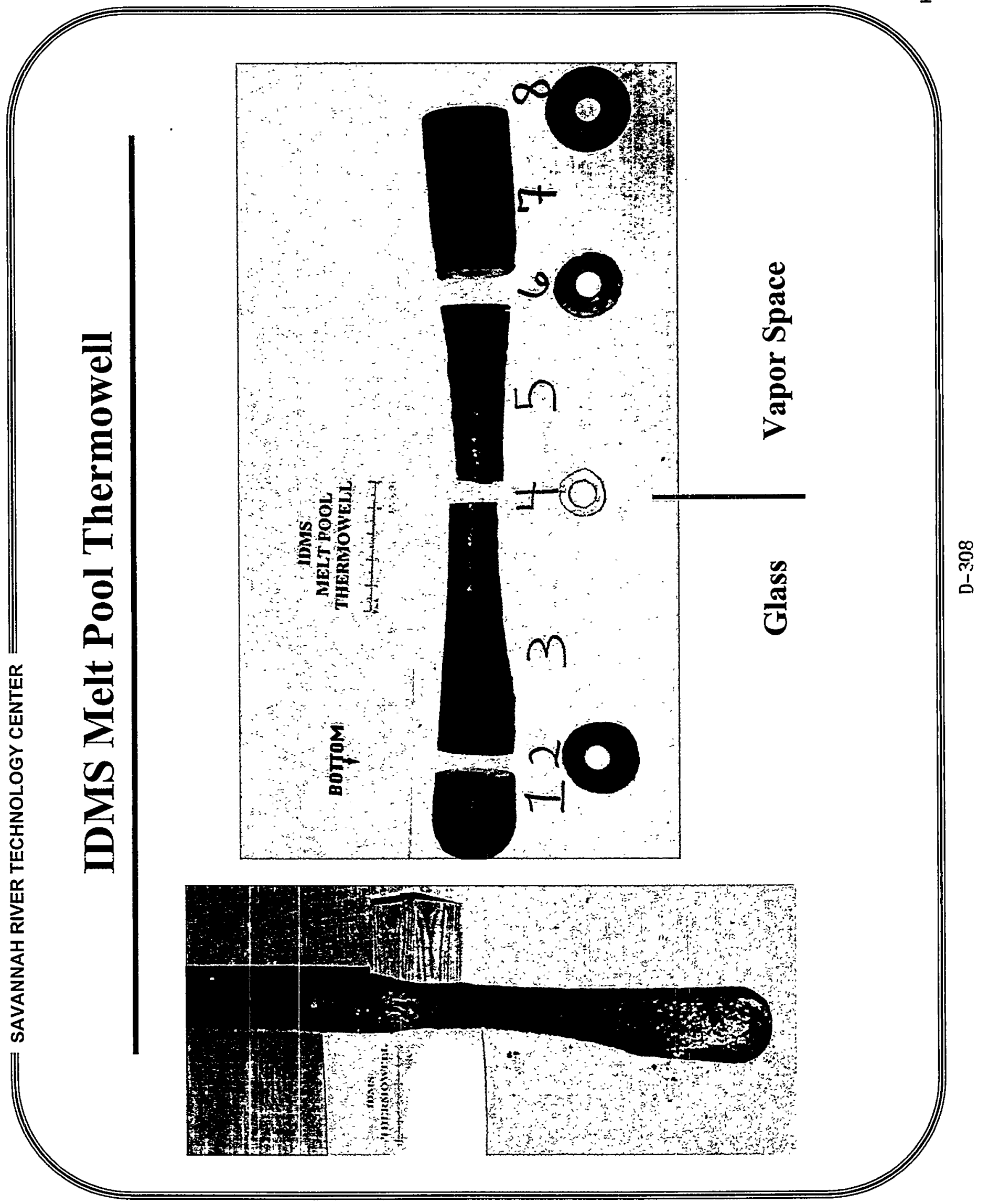




\section{IDMS}

\section{Lid Heaters}

- Component Background

- Inconel 690

- 7 years service

- High temperature

- Corrosive vapors

- No salt deposits on heaters

- Condition

- Excellent Condition (no distortion or significant material loss)

- Possible oxidation (metallurgical samples were not removed from the heaters 


\section{IDMS Lid Heaters}

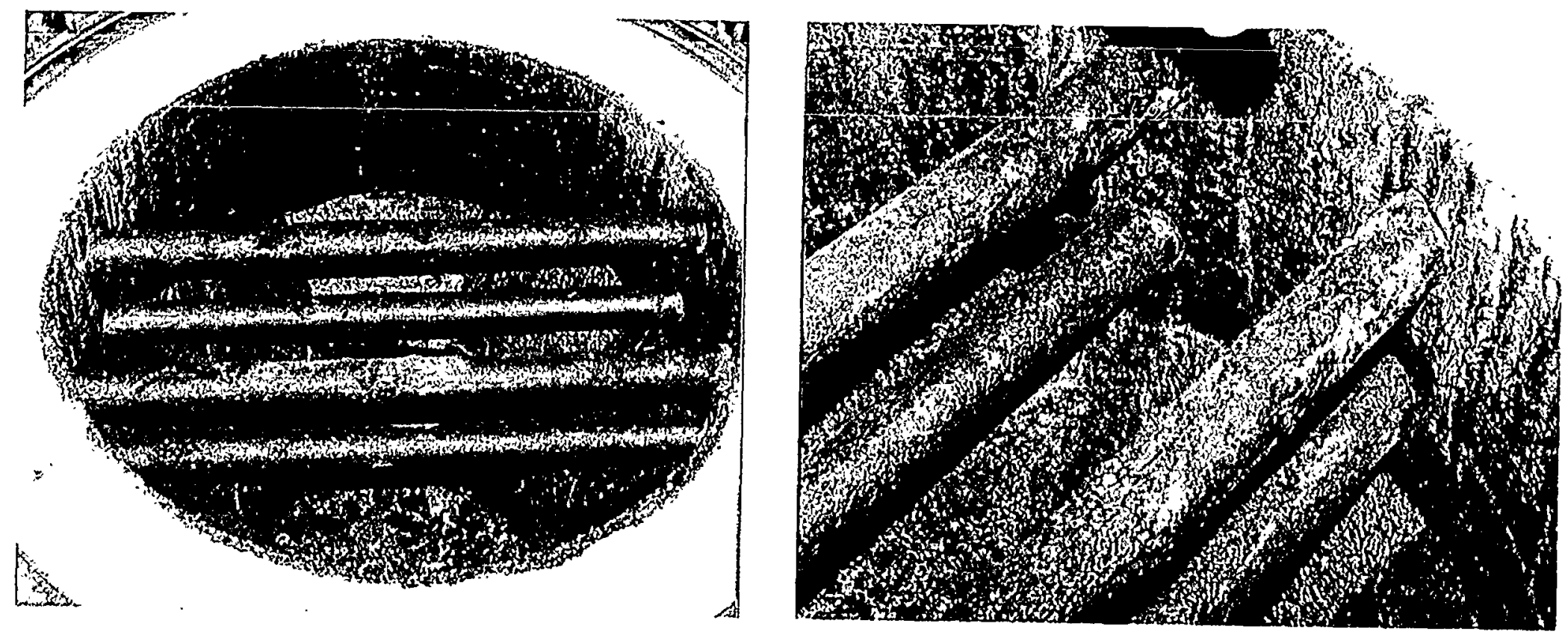

Condition before cleaning (sand blasting) 


\section{IDMS \\ Feed Tube}

- Component Background

- Inconel 690

- 7 years service

- High temperature (lid heaters)

- Corrosive vapors

- Salt deposits

- Problem

- Severe corrosion / IGA near melter lid 


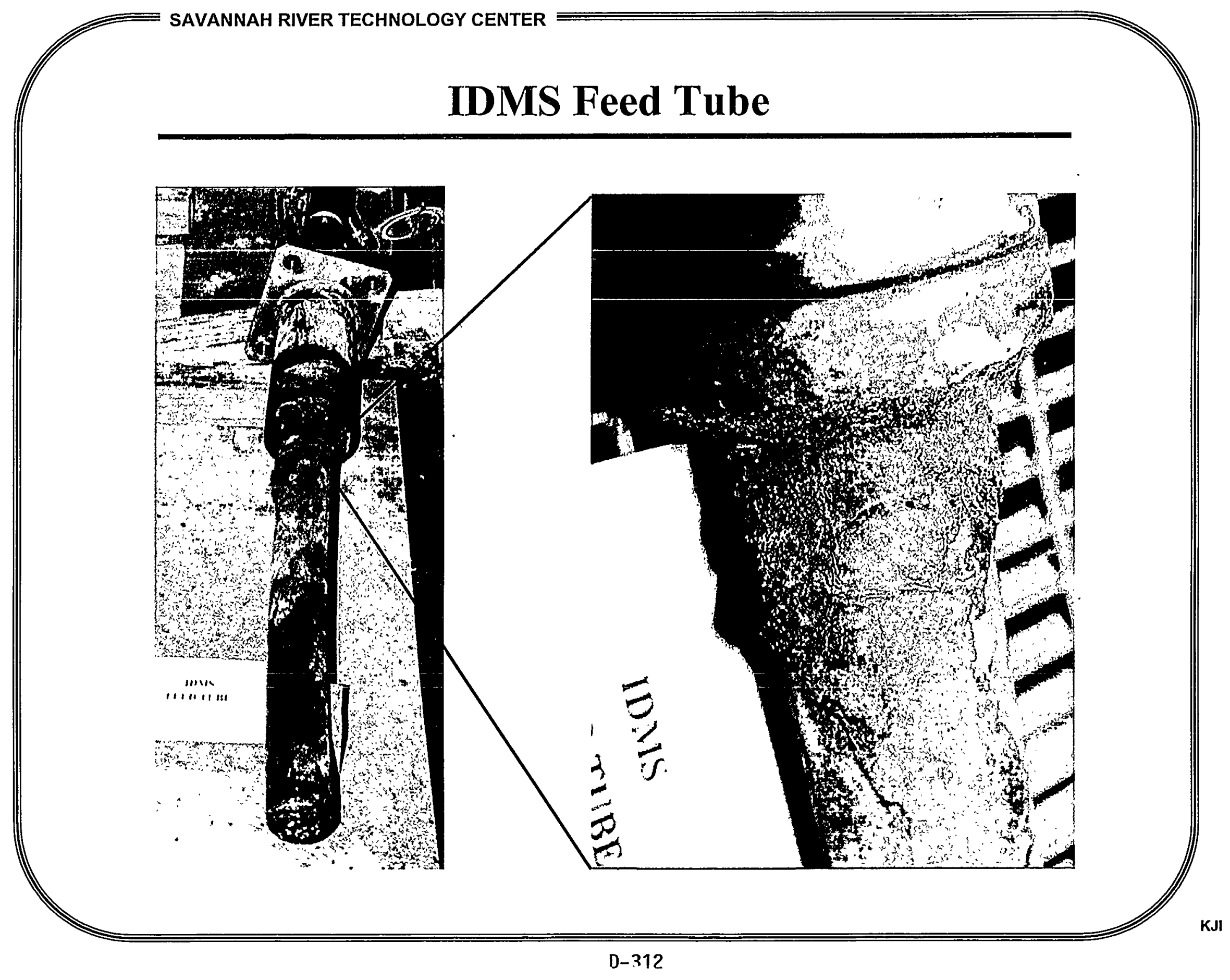




\section{IDMS}

\section{Film Cooler \& Vent Line}

- Component Background

- Inconel 690

- 6 years service

- Air purge

- High temperature (gas and radiant heat from lid heaters and molten glass)

- Corrosive vapors and salt deposits

- Problem

- Oxidation / Corrosion 


\section{IDMS Filmcooler\& Vent Line}

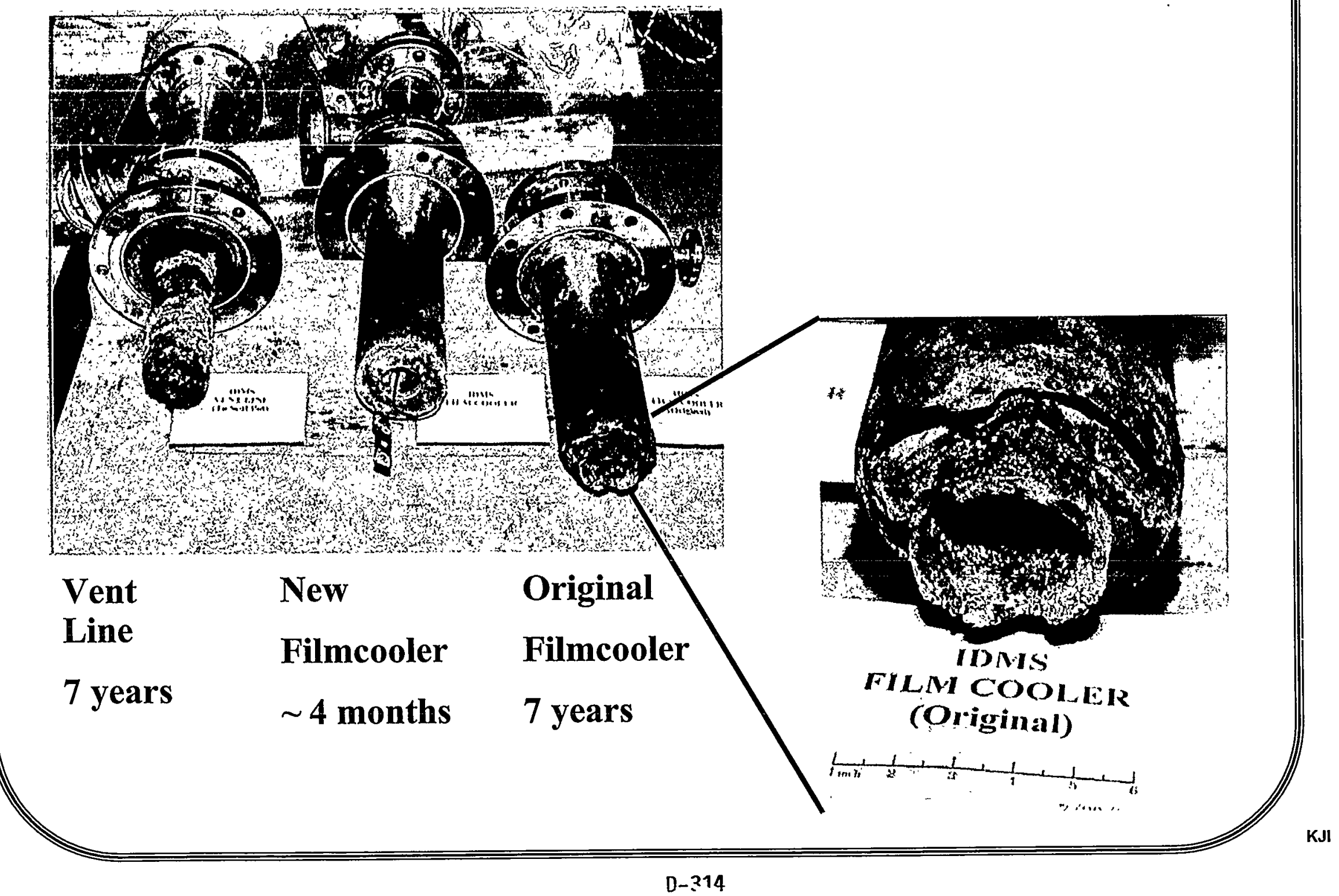




\section{IDMS Drain Valve}

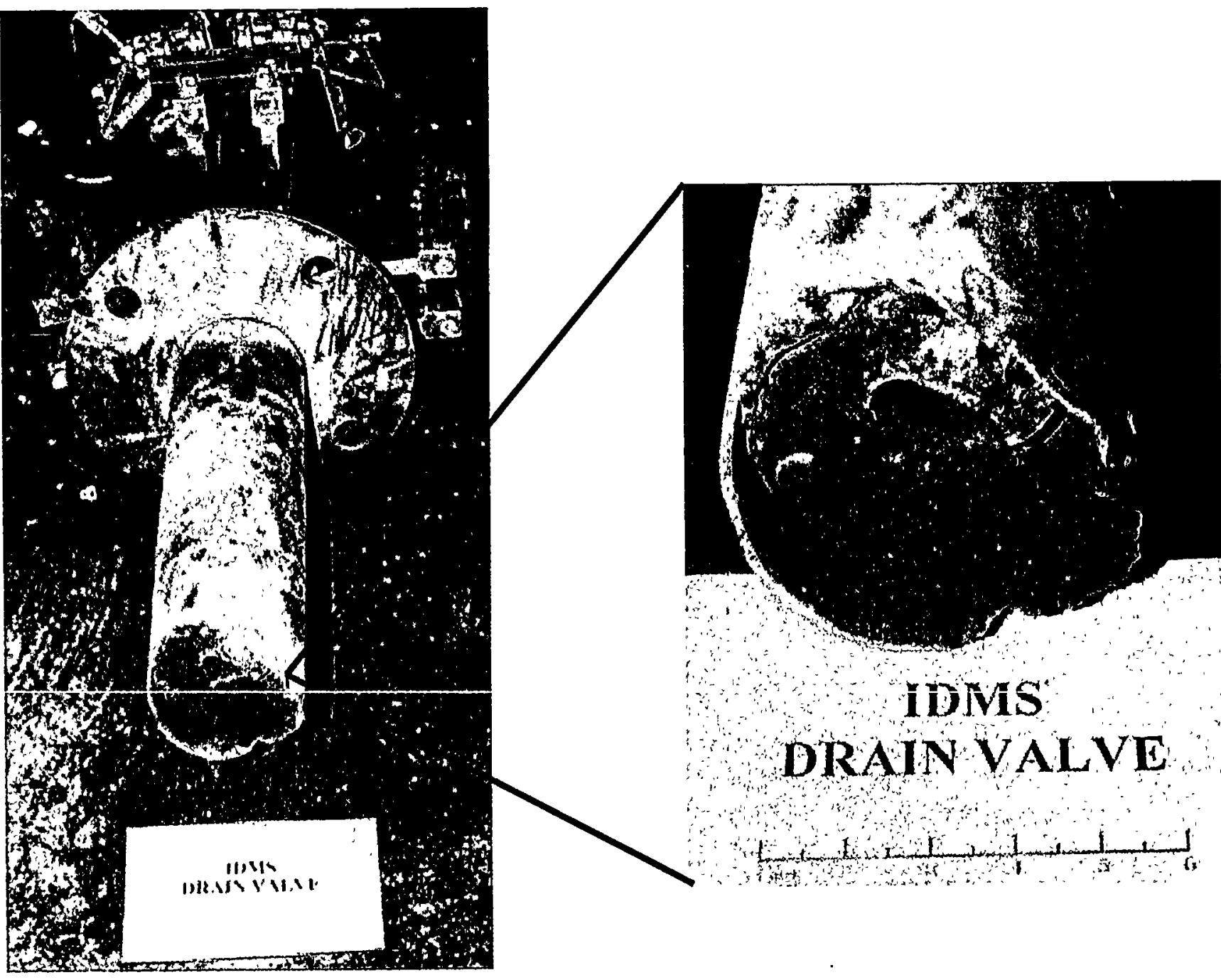




\section{Distribution}

No. of

No. of

Copies

OFFSITE

$2 \quad$ U.S. DOE/Office of Scientific and Technical Information

Copies

\section{ONSITE}

2 DOE Richland Operations Office

P. O. Box 550, MSIN: K8-50

Richland, Washington 99352

1 DOE Idaho Operations Office

750 DOE Place, MSIN: 1145

Idaho Falls, ID 83402

Attn: Keith Lockie

Attn: T. P. Pietrok

$\mathrm{K} 8-50$

D. Brown

$\mathrm{K} 8-50$

$2 \quad$ PHMC. Hanford

Attn: J. O. Honeyman R2-58

S. L. Lambert R3-75

15 Idaho National Engineering and

Environmental Laboratory

P. O. Box 1625

Idaho Falls, ID 83415

Attn: A. K. Herbst

MS 5218

J. D. Herzog

MS 3710

J. L. Law

MS 5218

C. A. Musick (4)

MS 5218

A. L. Olson

MS 5218

W. B. Palmer

MS 3211

J. Rindfleisch

MS 5218

B. A. Scholes

MS 5218

R. D. Tillotson

MS 5218

T. A. Todd

MS 5218

J. H. Valentine

MS 3211

A. Chambers

MS 3625

20 Westinghouse Savannah River Co.

SRTC, Bldg. 773-A

Aiken, South Carolina 29808

Attn: D.F. Bickford (4)

773-43A

T. B. Calloway

704-1T

R. J. O'driscoll

704-30S

R. F. Edwards

704-25S

J. T. Gee

704-25S

C. R. Goetzman

773-A

E. K. Hansen

704-T

E. W. Holtzscheiter

773-A

D. C. Iverson

704-30S

W. D. Kerley .

704-S

J. C. Marra

773-43A

S. L. Marra

704-T.

D. K. Peeler

$773-43 \mathrm{~A}$

C. T. Randall

$773-42 \mathrm{~A}$

34 Pacific Northwest National Laboratory

Attn: W. F. Bonner K9-14

T.M. Brouns $\quad$ K9-69

J. L. Buelt K9-09

M. L. Elliott $\quad \mathrm{K} 6-24$

W. L. Khun K7-15

R. L. Gilchrist K9-91

J. M. Perez H6-61

L. M. Peurrung K6-24

G. L. Smith K6-24

H. D. Smith K6-24

S. K. Sundaram (10) K6-24

J. H. Westik K9-91

B. J. Williams (TFA)(8) K9-69

Tech. Report Files (5) P8-55 
Westinghouse Savannah River Co.

(contd.)
F. G. Smith
774-42A
M. E. Smith
$773-43 \mathrm{~A}$
J. R. Zamecnik
$773-41$

1 ENVITCO, Inc

Attn: David M. Bennert

1 Florida International University

Attn: Rajiv Srivastava

2 GTS Duratek/BNFL

Attn: B. W. Bowan

Will Eaton

5 France/COGEMA

Attn: Sam Ashworth

Antoine Jouan

G. Melhman

R. D. Quang

V. K. Sazawal

2 Germany

Attn: W. Grünewald

S. Weissenburger

1 Russia

Attn: Serge V. Stefanovsky

1 Southwest Research Institute

Attn: Vijay Jain

$1 \quad$ West Valley

Attn: Steve Barnes 